


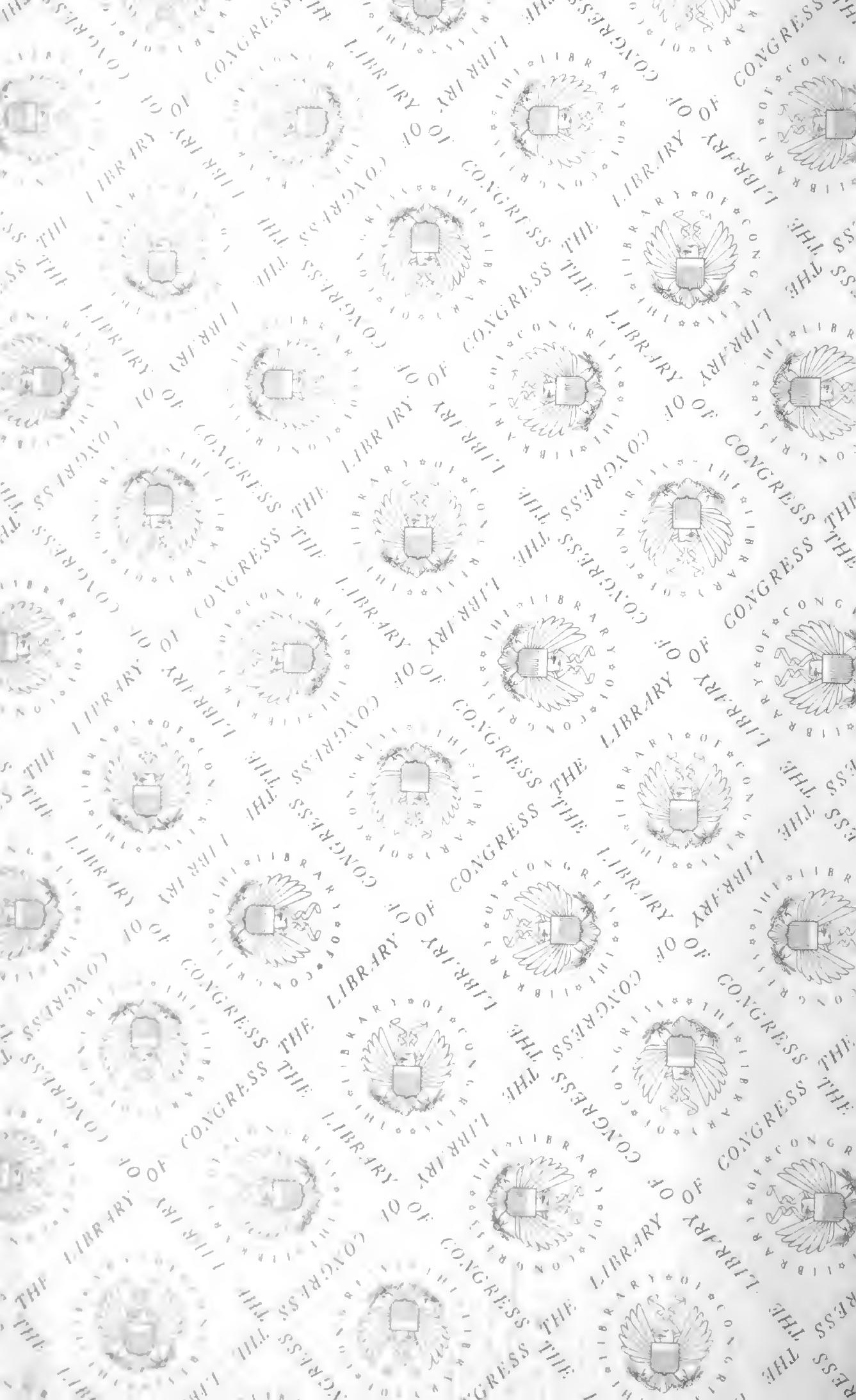




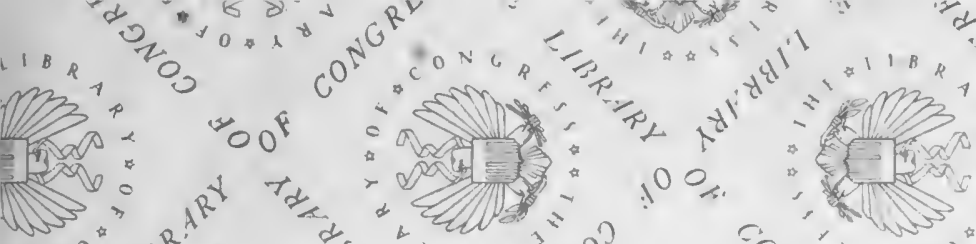

s.

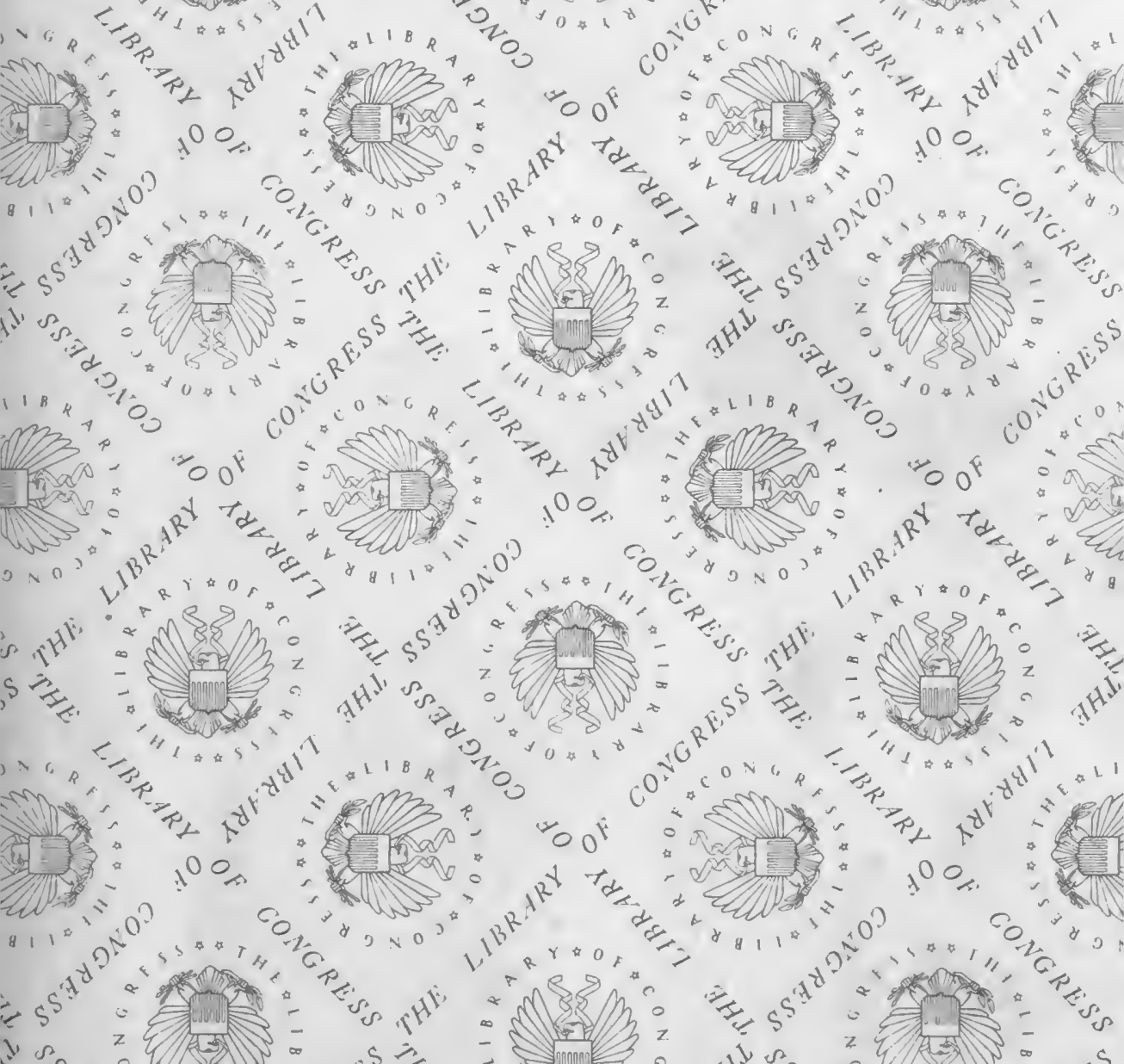

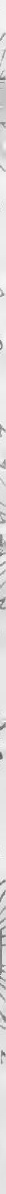

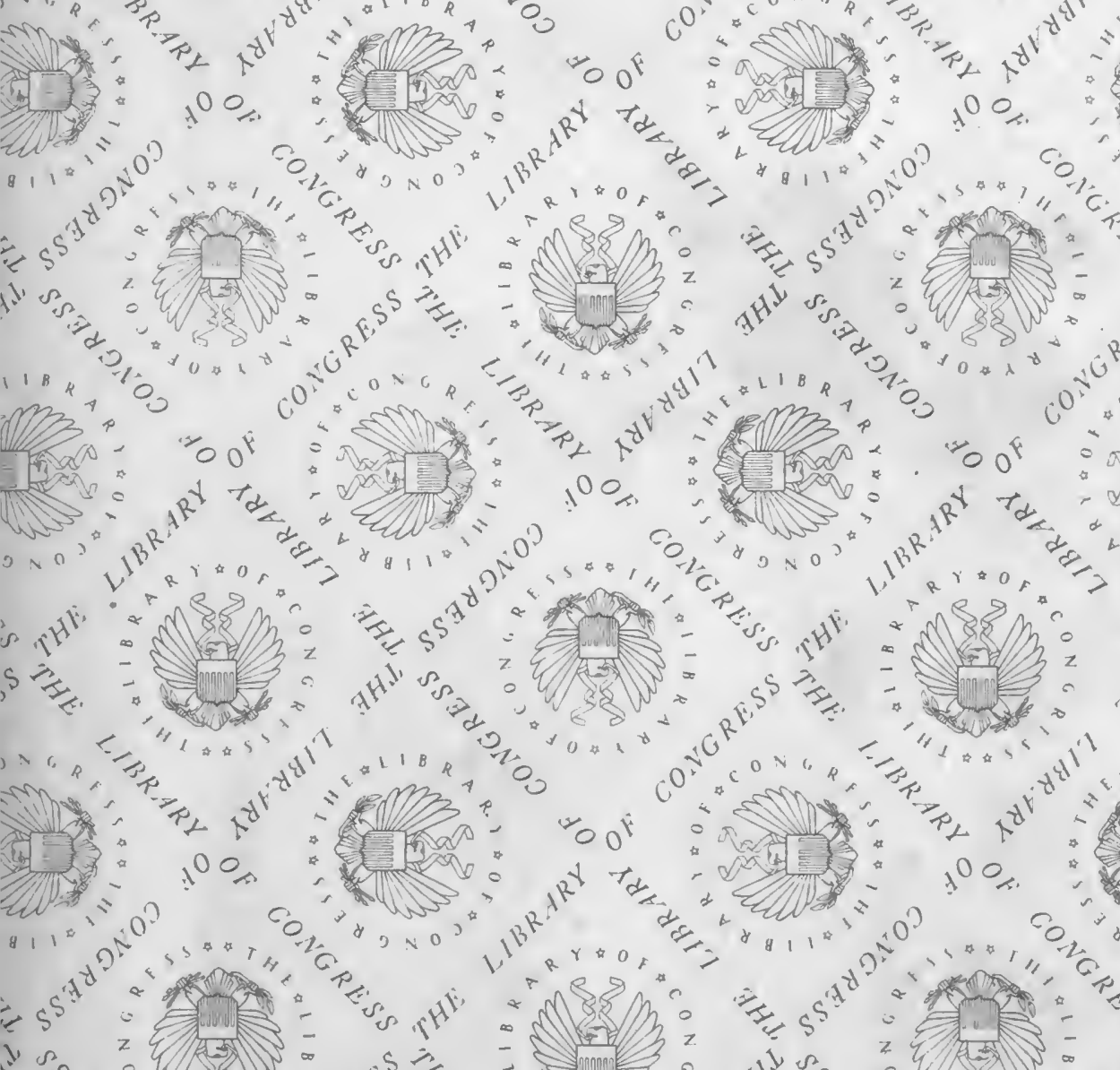

$\operatorname{son}^{2}=$

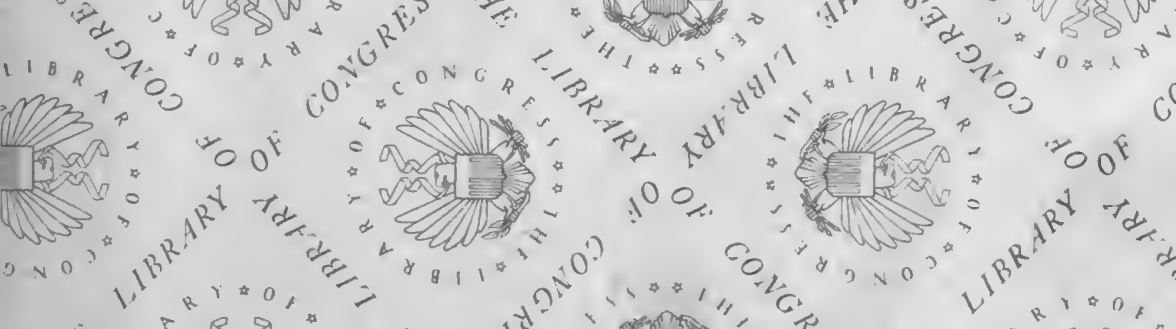

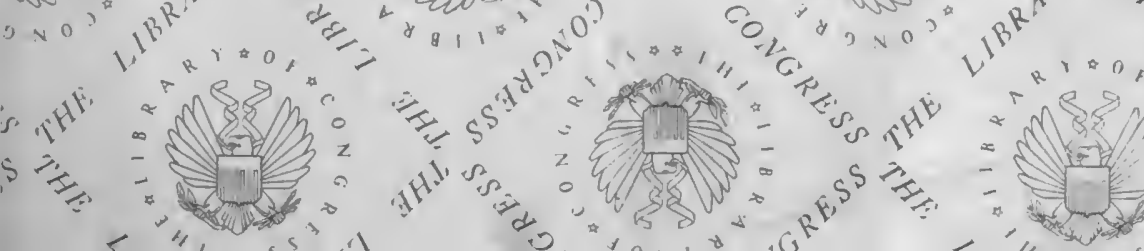


. (

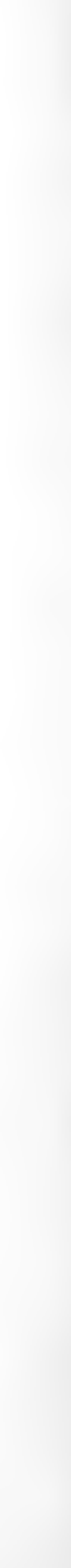




American-Japanese Relations 



\section{American-Japanese Relations}

An Inside View of Japan's

Policies and Purposes

By

KIYOSHI K. KAWAKAMI

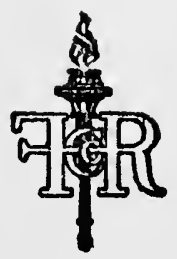

New York Chicago Toronto

Fleming $H$. Revell Company

LONDON AND EDINBURGH 


$$
\begin{aligned}
& 135849 \\
& 46 \mathrm{~K} 2
\end{aligned}
$$

New York: 158 Fifth Avenue Chicago: 123 North Wabash Ave. Toronto: 25 Richmond Street, W. London: 21 Paternoster Square Edinburgh: 100 Princes Street 
To My Daughter YURI ALBERTA

and

My Son HIROSHI CLARKE

in the hope that they will in their maturity contribute their quota to the promotion of friendly relations between Japan and America

this book is affectionately dedicated 


\section{Acknowledgment}

Chapter I of this book originally appeared in the Forum, Chapters II and VIII in the Pacific Monthly, Chapter XXIII in the North American Review, Chapter XV in the World To-Day, while Chapters III, V, VII, XII, XIX and XX were published in the Taiyo, a monthly magazine in Tokio, Japan. Acknowledgment is due to the editors of these publications for the courtesy they have extended to the author in permitting him to incorporate in the present volume these articles with such revisions as he deems necessary to bring them up to date.

The author is particularly indebtec' to Mr. Frank Putnam, of the Houston, Texas, Chronicle, who read the manuscript from beginning to end. Indeed, without his coöperation, sympathy, and encouragement, the book might never have seen the light. The author is also indebted to his wife for a similar assistance.

Kiyoshi K. Kawakami. 


\section{Contents}

INTRODUCTION $\quad \cdot \quad \cdot \quad \cdot \quad \cdot \quad \cdot$ I I

\section{BOOK I}

The Manchurian QUeSTION

I. What the War Conferred Upon Japan in Manchuria $\quad \cdot \quad \cdot \quad \cdot \quad \cdot 23$

II. The Manchuria of To-Day • • $\quad 36$

III. American Policy in Manchuria - 58

IV. Chinese Diplomacy in Manchuria • 78

V. Russo-Japanese Relations in ManCHURIA • • •

VI. Japan's Commercial Advance in MaNCHURIA AND THE "OPEN DOOR" • II 3

VII. American Trade in Manchuria and the "Open Door" . . . .

\section{BOOK II}

The Korean Question

VIII. Why Japan Occupied Korea . • • 143

IX. America's Diplomatic Relations with KOREA • • • • • • I 57

X. JaPANeSE Enterprise in Korea • . I72

XI. What Japan Has Done for Korea - I 86 
XII. Judicial Reform and ExterRitoriality IN KOREA • • • • 202

XiII. Japanese "Outrages" in Korea • • 214 XIV. The Annexation of Korea . • . 230 XV. AMERICAN Enterprise in Korea • • 242 XVI. American TRADE IN Korea and the "OPEN DOOR" • . . . 255

XVII. American Missionaries in Korea • • 266

\section{BOOK III}

\section{THE IMMIGRATION QUESTION}

XVIII. Japanese Immigration Before the ExClusion Agreement • • . 285

XIX. Denis Kearnyism Once More-I - 302

XX. Denis Kearnyism Once More-II • 317

XXI. Japanese Immigration After the EXClusion Agreement . . . 331

XXII. The Japanese in California . • . 343

XXIII. The Naturalization of Japanese • . 356 INDEX • • • • • • $\quad 367$ 


\section{Introduction}

T OOKING back over the past several years of American-Japanese intercourse one is struck with the radical change that has come over the sentiment of the American nation towards Japan. It is as if long and tried friendship, for some strange inexplicable reason, suddenly cooled to the point of revulsion.

Fifty years ago the Republic sent to the Sunrise Empire, still shrouded in the atmosphere of a fairy-land, an ambassador of peace and good-will, and lifting the infant nation from the cradle of seclusion, introduced it to the dazzling concourse of powers. From that time the United States fondly looked upon the insular nation as her protégé, and guided and guarded it through storm and sunshine as it carried its unsteady steps onward and upward along rough and untried roads.

Meanwhile, the docile youth-for such was Japanproved also the most strenuous. With amazing rapidity he acquired the arts and learning which were the fruits of centuries of hard labor in the Occident. Thus equipped with weapons of modern civilization which he had imported from the West, he met in the field of battle one of the most formidable gladiators of Europe. As the doughty islander dealt at his giant adversary blow after blow each with an unerring hand, the American public cheered him on with peals of applause, and the plaudits never ceased as long as he occupied the arena.

The combat came to an end through the good offices 
of Mr. Roosevelt. Japan was no longer an infant nation to be petted and patted. She had vindicated her right to a place in the comity of great powers, and the world was forced to recognize the fact. Then destiny abruptly adjusted the balance, and the American nation, which had measured out to the Japanese nothing but golden opinions and roseate views, began to look askance at the islanders.

What is the cause of this sudden change? Can it be attributed to the jealousy of America? Decidedly not. It is impossible to imagine that a great nation like A merica could be envious of the success of a little nation like Japan, towards which it assumed the attitude of a patron for nearly half a century. Can it be possible, then, that America is fearful of Japan's military prowess? A country, endowed with unlimited resources, occupying a position which is geographically impregnable, and, above all, noted for the bravery and patriotism of its sons, certainly need not be alarmed by what modest armament an impecunious nation such as Japan is striving to maintain merely to defend the position it has already attained.

And yet some of the American financiers, publicists and officers appear ever and anon in the lime-light of propaganda and proclaim to the four quarters of the world that America is building dreadnaughts and fortifying the Pacific Coast with an eye on Japan. To add sensation to the chorus of such alarmists, some of the American newspapers, and they are many, hold up before the curious gaze of an unthinking public the spectre of a Japanese invasion. I confess I do not understand what this all means. I have heard some Americans suggest that the root of the trouble lies in the sinister designs 
concocted by "predatory wealth," as the "muck-raker" calls the great "interests" of the country. When I am almost inclined to lend ear to this view, I begin to think how opulent this country is, and what great opportunities are in store for American trade and enterprise here on this side of the globe, and I cannot help wondering if $\mathrm{my}$ American informants are not, after all, mistaken. How can I believe that American financial magnates and captains of industry, with their coffers overflowing with gold, would conspire to spread war talk so that they may sell their government more war-ships and more guns? How can I believe that these men, to whom destiny has apportioned nothing but prosperity, would exploit the newspapers and invoke the influence of their government to check Japan's commercial advance in Manchuria so that they may build there their own railroads and sell their own goods? Ah, that is unthinkable!

Meanwhile, belligerent words continue to be spoken, and alarmist notes continue to be sounded. The average American, by reason of want of unbiased information, is apparently inclined to listen to the counsels of jingoes and alarmists. Thus the cloud of misunderstanding is growing thicker every day, casting its gloom over American-Japanese relations. The stage is reached, it seems to me, where the clearing of this misunderstanding should no longer be delayed, if friends, such as America and Japan have been, are not to be estranged beyond the point of reconciliation. It is with this need in view that this humble volume is presented to the American public.

There are three questions which have been and still are the source of more or less serious misunderstandings among Americans. The first of these is the Manchurian question. During the past half decade Europe and 
- America have been flooded with literature denouncing Japan's modus operandi in Manchuria. Thus an impression has been created in this country that the Mikado's Empire is, by surreptitious means, practicing wholesale discrimination against American commercial interests in that region. It is further asserted that Japan is dealing with China in an overbearing manner, encroaching at every point upon the sovereign rights of the Celestial Empire. When the seven chapters in which I shall discuss the Manchurian question are perused, the American public will, I hope, at least understand that such charges are not founded upon facts.

The second question to which I would call attention is the Korean question. Here again Japan is accused of slamming the "open door" and of treating the Koreans in a manner which is an outrage to humanity. Whether or not Japan deserves such accusations I ask the public to judge for itself in the light of the facts which I shall set forth in this book.

The third and last question which I propose to discuss is the immigration question. So far as the governments of the United States and Japan are concerned, this question is a dead issue. Japan is firmly pledged to adhere to the spirit and letter of the so-called "gentlemen's agreement," and will exert all her influence to check the emigration of her nationals of the laboring class to the United States. Nor will this policy of Japan be altered with the change of cabinets, for in all important matters affecting foreign relations a Japanese cabinet always adopts the policy of its predecessor. The administration at Washington fully understands the intentions of Tokio, and is, moreover, satisfied with the results already accomplished by the present arrangement. This sentiment of 
the American government is indicated by the omission from the new treaty with Japan of all reference to the exclusion of Japanese laborers.

And yet the Pacific Coast continues to agitate against the Japanese. Since 1906 not a year has passed but antiJapanese bills of one sort or another were introduced in the legislature of California. How long will this state of things be permitted to prevail without disturbing the equanimity of the Japanese? The enlightened class of Japanese appreciate that America as a nation is friendlily disposed towards Japan, but the masses are beginning to wonder if the Americans are not a sort of people who blow hot and blow cold. And who can blame them?

Here a few words seem not superfluous with regard to the attitude of the Japanese people, not the government, towards the immigration question. Official opinions, expressed in super-polite terms, may assure you that the people of Japan have little to complain about the exclusion agreement now in force. I am constrained to say that such is not the case. On the contrary, the Japanese feel that, viewed in the light of the real status of Japanese immigration, such a drastic measure of exclusion as was adopted by the two governments is not justified. Anxious as they are to maintain amicable relations with America, they will acquiesce in the arrangement as long as it is binding, but deep in their hearts they feel that America is not treating them in a spirit of fairness. Whether this sentiment is justified or not I shall discuss in the proper place. Here I ask attention to the following paragraph in one of Count Okuma's essays incorporated in "Fifty Years of New Japan," edited by the Count himself :

"I am well aware that behind this anti-Japanese senti- 
ment there exist various circumstances which deserve consideration. However, in so far as our people are disliked because they are Asiatics, there is nothing reasonable or logical in this hostile feeling. Such a passion or sentiment arises solely from narrow and biased racial prejudice on the one hand, and from misconceptions born of competition among the laboring classes on the other. To reason against and to remove these prejudices and misconceptions is a mutual duty devolving as much upon our people as upon the Western nations concerned. We have no occasion to be deterred by doubts or to hesitate in pressing for the satisfaction of our just demand. I do not in any way sympathize with the idea that by sending abroad emigrants who become a cause of domestic trouble in the country of their destination, the rights or honor of a great and civilized nation, such as ours claims to be, will be served. But I contend that when a treaty power seeks to enact a law restricting the immigration of our laborers, the terms of such restriction should be analogous and even identical with those applicable to the peoples of other great powers or civilized countries."

Perhaps I am not far from the truth when I say that these words of Count Okuma's voice the general sentiment among his fellow countrymen. Count Okuma is not a mouthpiece for the Japanese government. He has been out of power for a score of years, and has been the most fearless critic of the policy of the government in which he occupied a portfolio at various times. At the same time, it must be remembered that he is far from a jingo, such as the American newspapers represent him to be because of his opposition to the exclusion agreement. On the contrary the Count has been an ardent 
advocate of international peace, and is the organizer and president of the Peace Society of Japan. A man of remarkable magnetic power, he has admirers throughout the Mikado's realm, and his views on the immigration question no doubt exercise great influence among the masses.

I have explained the scope and nature of the following studies. Let it be far from me to claim that these studies are absolutely free from errors and misconceptions, for "we are none of us infallible, not even the youngest of us"; but I can at least say that they are the result of conscientious and painstaking investigations. My conclusions may not always be correct, my estimates may sometimes be imperfect; but they will be honestly given, as far as the knowledge and conviction of the author are concerned.

To which it may be added that my absorbing interest is in the furtherance of friendship and good-will between my native country and the country which I have virtually adopted and for which I cherish affection and respect, even though its laws compel me to live here as a pilgrim and an alien. The fact that $I$ have strong confidence in the good sense of the American nation in general makes me regret all the more deeply that some Americans and American newspapers indulge in idle and harmful talk of an American-Japanese war. I fail to understand the mental state of those persons who would link the rushing of American troops to the Mexican border with anything Japan intends or does not intend to do. As well try to connect Halley's comet with this globe of ours by a line of railroad! It is very well for these wiseacres to speak of "object lessons," but should they not remember that such object lessons as they fancy this country is giving 
Japan can make little impression upon a nation which attained the position it occupies through fire and blood? To the Japanese, who have fought two great wars within the past fifteen years, the mere mobilization of troops or the manœuvres of war-ships are a pastime. Furthermore, you cannot intimidate by " object lessons " a nation which is thoroughly confident of the probity of its conduct in dealing with foreign nations, most of all with your country.

It is strange that the Americans, sagacious as they are, did not long before this awaken to the fact that their sensational vociferations could only recoil upon them and injure their dignity and prestige. While the jingoes and alarmists of this country have been busy chasing the phantom of an American-Japanese war, the little nation across the Pacific has invariably remained serene and equanimous. Never once have the Japanese press and people spoken to you in bellicose tones, but have borne the indignities, to which your whims subjected them, with perfect dignity and calmness. So far as Japan is concerned, there is absolutely no reason to fear the rupture of amicable relationship between the two countries, for among the forty millions of the Mikado's Empire not a single soul is to be found who even dreams of ever taking arms against America. I, of course, hazard no prophecy that American interests will never conflict with those of Japan, but I believe that any controversy arising out of such conflict can be and ought to be disposed of in an amicable manner, by mutual restraint, tolerance and concession. It is time that America should conduct herself in a manner that becomes the power, wealth, and culture that inhere in her. It is time that Americans should awaken to the grave situation which cannot fail 
to result if they persist in playing the role of a provocateur -unless, forsooth, they are really anxious to create a casus belli. These are plain words, but I say them in the name of international deportment, peace and amity. 



\section{BOOK I}

\section{The Manchurian Question}



WHAT THE WAR CONFERRED UPON JAPAN IN MANCHURIA

T $T$ is five years since the Titanic struggle between Japan and Russia passed into history, and it may 1 seem trite to describe at this moment what the war conferred upon Japan in Manchuria. Yet to most Americans the issues of the conflict have been vague and misty-so much so, indeed, that even a writer, who seems to be generally recognized as the greatest American authority on the Far Eastern question, has unwittingly disseminated misleading information on the matter. Nor is this surprising when it is remembered that half a decade ago the American public had not sufficient interest in Manchuria to observe with critical eyes the consequence of the war, and all that it signified. The "open door" had been declared by Secretary Hay, it is true, but the Far Eastern policy of America did not as yet assume the aggressive nature it now assumes.

With the inauguration of the Taft administration all this has changed. The new cabinet insisted upon the right of participating in the gigantic loan for the CantonHankow and Hankow-Szchuen Railways; Mr. Knox's novel scheme for the " neutralization" of the Manchurian railways aroused mingled surprise and curiosity throughout the civilized world, even as Halley's comet blazoned through the heavens to the awe and wonder of myriad humanity; and, what is more vital, America proposes to build in Manchuria a line of railway extending over 
eight hundred miles. Mr. Taft's Shanghai speech of October, 1907, has been disinterred by the press from the oblivion into which it was consigned, and is heralded, as if it were a message of warning, through the country from the shores of the Atlantic to the region beyond the Rockies. Such a radical alteration in the attitude of the Washington government towards the Chinese question could not fail to direct the attention of the American people to whatever is transpiring in the Far East, and even the man in the street, as if awakened from a protracted slumber, now rubs his eyes, and asks "What is the matter with that country Manchuria, anyhow? What is Japan doing there, and what are we going to do about it?" These questions cannot be answered without going back to the condition which prevailed in Manchuria in the wake of the war, because that condition must needs form the starting point in our study of the Manchurian question.

Needless to say that the new condition in Manchuria is due to the injection of Japanese influence into the situation. To ascertain, therefore, what Japan acquired in Manchuria as the result of her victorious campaign against Russia is essential to the study of the radically altered situation in the Three Eastern Provinces, as Manchuria is called by the Chinese. For this purpose it is necessary to examine the Russo-Japanese Treaty of Peace, and various other documents bearing more or less important relations to that treaty. Not less important than the peace treaty is the Chino-Japanese treaty concluded at Peking in December, 1905, as well as the protocol to that instrument. The fact that the Portsmouth treaty required China's consent to confirm the transfer to Japan of the Russian railways in South Manchuria, be- 
hooved Japan to send an envoy to Peking immediately after the Portsmouth conference in order to obtain the said consent, and to make such other arrangements as were deemed essential to the readjustment of the respective positions and policies of Japan and China with regard to Manchuria. The result was the treaty of December, 1905, which in history is referred to as the KomuraYuanshikai Treaty after the names of the Japanese and Chinese envoys, who were instrumental in drafting that memorable document. In virtue of this instrument, China indorsed the transfer of properties and privileges made by Russia in favor of Japan. We shall presently see what these properties and privileges are.

In the first place, Japan has secured the lease of Port Arthur, Ta-lien (now Tairen), and the adjacent territory and territorial waters. To the average mind, however, the extent of the lease is anything but clear. Indeed, the popular misconception on this point has been such that even the author of a brilliant book on the Far Eastern question is worried not a little, because in the Russo-Japanese Treaty of Peace the term "Liao-tung Peninsula" instead of "Kuan-tung Peninsula" is used in describing the territory covered by the leasehold which Russia transferred to her victor.

As a matter of fact, the word "Kuan-tung" is no less ambiguous a term than "Liao-tung," and needs to be so defined as to admit of no misconstruction. Consequently, Article 5 of the Russo-Japanese Treaty of Peace, wherein the territory in question is defined, deliberately avoids referring to either the one or the other of these terms, but unmistakably indicates that Japan's acquisition in this respect is neither greater nor less than what Russia held in the peninsula before the war. 
In order, however, to ascertain the exact alignment of the leased territory, it behooves us to go back to the Russo-Chinese Treaty of March 27, 1898, as well as to the convention concluded a little later between $\mathrm{Hsu}$ Tajen, the Chinese minister at St. Petersburg, and the Russian government. According to these documents, the leased territory covers the whole of that portion of the Liao-tung Peninsula lying to the south of an imaginary line drawn from $\mathrm{Pu}-\mathrm{la}-\mathrm{tien}$, at the head of an inlet on the west coast, to $\mathrm{Pi}$-tsu-wo, a village on the east coast of the peninsula. To the north of the territory thus leased there is a " neutral zone" stretching to a line drawn from the mouth of the Kai-chou River to the south of the district city of Kaiping on the west coast, to a point on the Ta-yang River and down its right bank to the sea, and including the village of Ta-ku-shan on the east coast. In the neutral zone, China retains her jurisdiction, but relinquishes the right to quarter troops except with the previous consent of the power in behalf of which the lease is established. Such are the exact limits of the territory affected by the Russian leasehold. The duration of the lease is fixed at twenty-five years, out of which some seven years elapsed under Russian rule. Inasmuch as Japan, in the new treaty with China, is pledged to adhere to the stipulations of the RussoChinese treaty of lease, she must withdraw from the Liao-tung Peninsula at the expiration of eighteen years from the time of its transfer to Japan, unless the term be extended by the mutual consent of the high contracting parties.

Next in importance is the acquisition by Japan of the railway between Chang-chun on the north and Tairen on the south, covering some 436 miles, as well as the 
following three branch lines: Ta-shih-chiao to Yinkow, fourteen miles; the branch to the Fushun coal field, thirty-four miles; Nan-kuan-ling to Port Arthur, twentyeight miles. All told, the railways ceded by Russia to Japan amount to some 512 miles, for the building of which the former expended some $76,222,000$ rubles. In virtue of the Russo-Chinese agreement of September, I896, the concessionnaire country for these lines must hand over to the Peking government these railways and their appurtenances without compensation on the expiration of eighty years from the day of the opening of traffic along the main line of the Eastern Chinese Railway, $i . e ., 1903$. Besides, the Chinese government has the right, on the expiration of thirty-six years from the time of completion of the main line and its opening for traffic, to take over the lines entire, on refunding to the concessionnaire country all the outlays made on them.

In addition to the railways ceded by Russia, the ChinoJapanese Treaty of 1905 allowed Japan the right to reconstruct the military railway between Antung and Mukden, amounting to 189 miles, into a permanent line to be utilized for commercial purposes, the duration of the concession being fifteen years from the day of the completion of the reconstruction work.

According to an additional clause of the above-mentioned railway agreement between the Peking and the St. Petersburg government, the Eastern Chinese Railway enjoys the right to police a strip of territory extending for fifteen versts on either side of the railway line, as well as the right to exploit any mineral deposits within this strategic area. This latter privilege leads us to the consideration of the much talked-of coal mines at Yentai, Fushun, and Wa-fang-tien. The Yentai coal mines had 
been worked by Chinese until the Eastern Chinese Railway acquired them by purchase. The coal mines in the Fushun district and the Wa-fang-tien mines were also opened up by Chinese many years before the coming of the Russians. Since the Russians had taken possession of these mines, their poor management of business was responsible for so little improvement that the coal raised was insufficient to supply even the southern section of the Manchurian Railway. Besides these three mines, the Eastern Chinese Railway worked several seams, but in an aimless and shiftless fashion, abandoning them after a short experience. I shall relate in a following chapter how, under the efficient management of the Japanese, this deplorably nebulous state of things has been readjusted.

Now we come to the question of lumbering concessions, which furnished the world a topic of startling stories immediately preceding the Russo-Japanese war. The semi-official Russian corporation, the Yalu Lumber Company, having an imposing head office in Port Arthur, was concerned with lumbering on the Manchurian as well as the Korean side of the Yalu. This enterprise, political rather than commercial in its aim and nature, did not hit upon a working plan, and was already on the verge of dissolution. In consequence of the ChinoJapanese agreement of 1905 , the lumbering industry on the Chinese side of the Yalu River is now being undertaken by a joint-stock company organized by the high contracting parties, dividing the shares equally between Chinese and Japanese subscribers.

Such, in brief, are the rights and properties which the war left, in its wake, in the hands of the Japanese. Important as these material acquisitions are, we must not 
forget that even more important is the attainment by Japan of an end, which was the raison d'etre of the war and which is the sine qua non of her Manchurian policy -I mean the realization of the "open door."

The cardinal point of the Peking Treaty of December, 1905, is the clause in virtue of which Japan obliged China to open the following sixteen cities and towns " as places of international residence and trade":

Name of port

Feng-huang-cheng
Liao-yang - -

Hsin-min-tun -

Tie-ling -

Tung-kiang-tsu -

Fa-ku-men - -

Chang-chun -

Kirin - - -

Harbin

Nin-gu-ta - -

Hun-chun - -

San-sing - -

Tsi-tsi-har - -

Khai-lar - -

Ai-gun

Man-dju-li
Province Population
Feng-tien (or Sheng-king) 50,000

\begin{tabular}{|c|c|c|c|}
\hline & ،6 & 66 & 100.00 \\
\hline 6 & 6 & “ & 80,00 \\
\hline 66 & "6 & "6 & 100,00 \\
\hline 60 & “ & ، & Unknown \\
\hline 6 & 66 & ، & Unknow \\
\hline & Kirin & - & 250,00 \\
\hline & 66 & - & $-\quad 250,00$ \\
\hline & "6 & - & 250,00 \\
\hline & " & - & 40,00 \\
\hline & “ & - & 30,0 \\
\hline & “6 & - & 50,00 \\
\hline & ung-kis & & 100,00 \\
\hline & 66 & - & - Unkno \\
\hline & 66 & - & \\
\hline & 16 & & - Unkn \\
\hline
\end{tabular}

In classic, picturesque China it is a sacrilege to speak of statistics, and the above figures, gathered from various native sources, must be taken for what they are worth. This list of towns newly opened to foreign trade has to be enlarged by five additional ports, of which Newchwang and Tairen had practically been marts of international commerce for a number of years prior to the war, while the remaining three, Antung, Tatun-kow, and Mukden were opened in October, 1903, as a consequence of the joint agitation of the United States and Japan. All in 
all, twenty-one cities and towns in Manchuria have been thrown open to the commerce of the world. A glance at the map of Northern China reveals how carefully these places were selected. Taking the newly-opened sixteen ports, we perceive that their opening is of the utmost importance for the benefit of all nations standing for the maintenance of the integrity and the promotion of the economic prosperity of the Celestial Empire. In persuading China to throw open these ports, Japan no doubt had in view not only commercial, but also strategical considerations. When the smoke of the battle was just cleared away, the insular nation not unnaturally apprehended that the Muscovites, recovering their shattered power, might once again light the hills and plains of Manchuria with the lurid flames of war. Viewed from a strategical point, the Japanese considered, the five frontier or semi-frontier posts, Man-dju-li, Ai-gun, Khai-lar, Hun-chun, and Nin-gu-ta, when converted into marts of international trade, would prove a serious obstacle to Russian aggression upon Manchuria, for, through them, the frontier armaments and military activities of the Muscovite in the Far East would be readily exposed to the world at large.

The remaining eleven towns include most of the important trade entrepots in the maritime province and interior of Manchuria. Liao-yang, probably the oldest town in the Eastern Three Provinces, lies astride of the railway commanding the fertile Liao valley, which, famous with giant crops of kao-liang, or the tall millet, veritably flows with milk and honey. Tie-ling, Hsinmin-tun, Faku-men, and Tung-kiang-tsu are also situated more or less closely to the Liao River, the greatest trade artery in Manchuria, down which the produce of the far 
interior of that country and Eastern Mongolia are carried to the port of Newchwang. About half-way between Tieling and Harbin is the prosperous city of Chang-chun, which is aptly called the clearing house of inland Manchuria, being the distributing centre for trade to and from Kirin, Hei-lung-kiang, and Eastern Mongolia. Eightyfour miles from this trade depot is the old city of Kirin, the capital of the province of the same name, which, situated in the heart of a splendid timbered country, is so famous for the building of boats and junks that it is well styled the "dockyard." Finally, we come to the famous railway city of Harbin, which is the Russian metropolis of Manchuria.

The opening of these towns was effected immediately after the withdrawal of the armies of the Mikado and the Czar, which was completed before April I4, I907, in conformity with the evacuation agreement between the commanders of the formerly belligerent forces in Manchuria. The evacuation clause of the treaty of peace did not affect the railway guards in Manchuria, which the high contracting parties reserved the right to maintain to a number not exceeding fifteen per kilometre. As a consequence of the publication at Tokio of the proceedings of the peace conference, it transpired that during the Portsmouth conference Count Witte objected to Baron (now Marquis) Komura's proposal to fix the maximum number of guards, which was very significant in view of the fact that it had always been Russia's policy to utilize the railway as the forerunner of her conquering army. The Russo-Manchurian Railway was a military strategical railway guarded, as no other railway in the world was guarded, with blockhouses every three or four miles, and with garrisons at every important point adequate to 
quarter large numbers of troops. At the Peking conference of December, 1905, the Chinese plenipotentiaries expressed the desire to have the Japanese and Russian railway guards withdrawn as soon as possible, in deference to which Japan consented to withdraw her guards in the event of Russia agreeing to take a similar step. But until China's internal conditions are so readjusted as to afford ample protection to foreigners and their property within her borders it would be unreasonable for China to expect either Russia or Japan to withdraw her railway guards.

Immediately after the Peking conference of December, 1905, it was persistently rumored that Japan and China entered into a secret understanding which was of no smaller importance than the treaty made public by the respective governments. But this so-called "secret agreement," which is in reality open to the inspection of any one interested in the matter, is simply an arrangement relative to the building of the Kirin-Changchun and the Mukden-Hsinmintun Railways. It will be remembered that at the Portsmouth conference Japan originally demanded the whole of the Port Arthur-Harbin section of the Eastern Chinese Railway, and that Witte's refusal of this demand resulted in a compromise by which Russia retained to herself the Harbin-Changchun section of said line, recognizing in lieu thereof Japan's right to build the proposed line between Kirin and Changchun. At the Peking conference, however, the Chinese plenipotentiaries declined to endorse this agreement made between Japan and Russia, and the Mikado's representatives were forced to yield to another compromise, agreeing to construct the Kirin-Changchun line in conjunction with the Manchu government. This line, though 
only eighty-four miles long, was sought by Japan, because its connection with the Port Arthur-Changchun road will greatly enhance the value of the latter. When the Russian government contemplated the construction of that road in 1902, the semi-official Novoe Vremya said:

"This branch is important both for commercial and strategical reasons; for if our railway did not touch Kirin it would miss the great trading centre of that part of Manchuria. More trading routes pass through Kirin than through any other town in the province. It is a kind of junction for all the commerce of China with Northern Manchuria, Korea and the Amur regions, and through it pass the main roads leading to Mukden and Peking, to Korea and the Russian frontier."

Another arrangement made by the so-called secret agreement relates to the military railway connecting Mukden and Hsin-min-tun, built by the Japanese during the war. As this road did not belong to the Eastern Chinese Railway, Japan could not convert it into a permanent line, without first securing the consent of the Chinese government. Having failed to secure such consent, Japan made an agreement in virtue of which China is to build said line with funds to be supplied by the Tokio government. The formal transfer of this line to the Chinese government took place in 1908.

The third and last settlement contained in the protocol is to the effect that the Peking administration shall not build a competitive line to the main line of the South Manchuria system. This condition Japan was obliged to impose upon the Chinese government from the necessity of protecting her Manchurian railways from total failure. The junk traffic on the Liao River and the Chinese rail- 
way across the river were, in themselves, a formidable rival to the South Manchuria Railway, and it seemed evident that the addition of another competitive line would all but supersede the Japanese line. How Japan, upon the strength of the understanding, protested against the Chinese scheme of the Shinmintung-Fakumen line, shall be described in the proper place.

Such, in short, are the main features of the so-called secret understanding incorporated in the protocol to the Peking Treaty of December, 1905. The protocol is included in the diplomatic documents of Japan and other powers, accessible to all students of international relations, and I wonder if Mr. Thomas F. Millard who, in his "America and the Far Eastern Question," says that he "could not obtain an official copy of this secret memorandum," took the trouble to spend a few hours in one of the admirable libraries for which his country is noted.

I have stated that at the Peling conference Japan made several important concessions in favor of China. She had fought China's battle as much as she had fought her own, sacrificing countless lives and spending hundreds of millions of dollars, and yet the Manchu government did not hesitate to deny her a few railway concessions which she was fully justified in claiming. Not only this, but the Chinese diplomats opposed and disputed Japan's demands at every point. They seemed to have forgotten that had not the doughty islanders taken arms against the Northern Colossus, Manchuria, with its area of 370,000 square miles and its $8,500,000$ population, would have been permanently lost to China, which in turn might have paved the way to the not impossible dismemberment of the hoary empire. I confess that it 
was one of the weaknesses common to humanity which caused the Japanese to presume that China would not ignore the appalling sacrifices they had made on behalf of the latter. And who could blame Japan? Disinterested she was not when she declared war in the name of the "open door" and the territorial integrity of China, for in this age of business and materialism, what nation can be so chivalrous as to jeopardize its own welfare and even existence from purely altruistic motives? At any rate Japan ought not to be accused of selfishness and mercenary motives if she did expect China to recognize her claims ungrudgingly_claims which were ridiculously modest as compared with the gigantic concessions and privileges which some Western powers extorted from the Peking government in consequence of the killing of a missionary or some untoward incident of like nature. I have it upon good authority that it was Japan's earnest desire to settle all matters, which had awaited adjustment between her and China, without recourse to diplomacy but in a friendly manner. Had this desire been gratified, Japan might have cast her lot with China and exercised all her influence for the regeneration of the decaying empire, and for the maintenance of its integrity against foreign aggression. But China's attitude throughout the entire sessions of the Peking conference was one of willful ingratitude and irreconcilable arrogance, and she tried to defeat Japan's aim by dint of diplomatic finesse, in which the mandarins excel the Japanese. Yet the Japanese envoys remained lenient and patient, and made many important concessions in favor of China, thus hoping to convince the Chinese of Japan's sincere wish for the welfare of their country. How far this hope has been realized we shall presently see. 


\section{THE MANCHURIA OF TO-DAY}

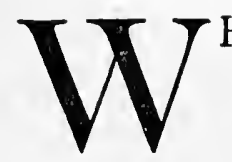

HILE in Harbin in the summer of 1908, I met an American gentleman travelling in Manchuria in the interest of several flourmilling concerns on the Pacific Coast. His chief mission in Harbin was to inquire into the conditions of the Russian flour mills there with a view to ascertaining whether by the application of up-to-date American machinery and business methods a better grade of flour could not be milled from Manchurian grain at a less cost than was then borne by the Russian mills.

Harbin, the Russian metropolis of Manchuria, boasts of eight flour mills with a daily capacity of $1,600,000$ pounds. A part of Russia's war performance, these mills were installed mostly on short notice in order to feed her soldiers in Manchuria. With the termination of the war the Russian demand for Harbin flour came virtually to a stop. It was understood three summers ago that the Russo-Chinese bank had millions of rubles locked up in mill-mortgages at heavy rates of interest, and most of the Harbin mills seemed but too anxious to sell out at the first convenient opportunity. It was undoubtedly this unhappy condition which suggested to some American concerns the idea of taking control of the Harbin mills.

But a nation like Russia endowed with much potential energy cannot be expected to succumb to the effects of 
a military misadventure, and abandon all the advantageous positions she gained in the Far East. As the memory of the disastrous war grows dim, the sense of doubt and misgiving which for a period depressed Russia is gradually giving way to the consciousness of latent strength and future possibilities which still remain hers. It is indicative of this reawakening that the Russian mills in Harbin, instead of considering any offer for purchase from foreign concerns, are now resuming their activities, intent upon making a powerful onslaught on the American flour trade in Manchuria. During the last year or two a liquidation was carried out in order to place the mills upon a working basis. Subsidized by the Russian government some of these mills have organized themselves into a sort of syndicate with a view to pushing their trade in South Manchuria, which has practically been monopolized by American flour.

How far the Russian mills have been successful and what their outlook is we shall see in a later chapter: here the story is introduced only as an instance of how Manchuria, recovering from the effects of the tremendous military upheaval, is settling down to the pursuits of commerce and industry. If Russian Manchuria is picking up with remarkable rapidity, even more remarkable is the manner in which the Japanese are pushing their enterprises in Southern Manchuria. Russia must perforce confine her activities, for the present at all events, to the mending of her shattered prestige and influence. With Japan it is different: she emerged victorious from the smoke of a prodigious conflict, and she entered into the field of commerce and industry with aspirations and energies, refreshed and stimulated by the victory. Her method is not so spectacular, so dazzling, so lordly in 
scale as the method pursued by Russia before the war, but she cares not to play to the gallery, nor does she care to beguile the world by bluffing and manœuvring. Western critics seem to think it their duty to remind us that we are getting "chesty" and "cocky"; be it so, for we are by no means free from human frailties. Yet we have never allowed the halo of the victory to wax so large as to obstruct our vision; we have been conscious of our limitations and weaknesses, and formulated our post bellum plans accordingly. Economical Japan perforce had to be, for her resources are scanty, but she is convinced that frugality, assiduity, unremitting toil, and organized efforts will ultimately overcome this drawback. Cautiousness born of this conviction is perceptible in every phase of her activities in Manchuria. Compared with the work of Russian empire-builders in Manchuria prior to the war, hers must indeed seem that of a pigmy before a giant. Small wonder that an American critic, whose hatred of the Japanese seems to have driven him even to praise Russia, indulges, from start to finish of his book, in such insipid sarcasms as this: "With the appearance of the Jap the era of high prices (in Manchuria) passed. The Japanese is not by nature and habit a free spender like the Russian."

Mr. Millard-for such is the name of this eminent writer-prefers to ignore that a prosperity flashed up by extravagance and reckless spending must necessarily be ephemeral and deceptive, and he stoutly refuses to recognize that the Manchurians are indebted to the Japanese for the phenomenal rise in the price of the beans, which constitute the wealth, indeed the life, of Manchuria.

The Japanese population in Manchuria has reached 
41,000, distributed along the lines of the South Manchuria Railway. Of this total Tairen has 17,000; Port Arthur 6,094; Liao-yang 3,290; Antung 4,377; Newchwang 2,590; Mukden 2,44I ; Tie-ling 2,216; Changchun 1,043; Harbin 986; Kirin 176; Kung-tsz-ling 426; Shin-minfu $18 \mathrm{I}$, the rest being divided among other minor towns. In Newchwang, Japanese, in conjunction with Chinese, installed an electric light and telephone system. At Mukden, Japan is laying out a settlement of five hundred and fifty acres at an expenditure of $\$ 4,000,000$. At Antung, Japan has spent liberal sums in providing well-laid-out streets, an excellently appointed hospital, a commodious school, a substantial post and telegraph office, and an extensive telephone system, while private enterprise has supplemented these official measures in the erection of substantial business and residence buildings. This Antung settlement is a part of the larger tract acquired by the Japanese military authorities in 1905, including all of the water-front below the Chinese town of Sha-ho-chien. Around the area thus selected for business and residence the military administration excavated in 1906 a ditch to drain the land, and erected a dike to protect it from the summer floods. For the crowning enterprise of the Japanese in Manchuria, however, we must turn to Tairen, which the Russians used to call Dalny. This Japanese metropolis of Manchuria covers an area of 24,720 acres, and is said to be capable of harboring a million population. Besides the Japanese population, numbering some 17,000 , the port has 70,000 Chinese inhabitants. While the town, with many substantial, even elegant, buildings, was originally laid out by the Russians, Japan is expending liberal sums to improve upon the original plan. The 
most important of these undertakings is the improvement of the harbor, comprising the construction of breakwater, piers and jetties, the embankment and reclamation of foreshore, the improvement of quays, and dredging work. The entire work is to be finished in seven years and will entail a cost of $12,050,000$ yen. The harbor of Tairen has advantage over Newchwang and Antung in that it is not only free from ice but is capable of admitting steamers of deep draught. Since I908 Japanese and Chinese merchants have been locating there in increasing numbers, and the city now boasts of two banks, forty commercial and nine industrial companies. In 1906 the exports through this port of beans and bean-cake totalled only $8,520,000$ yen in value, but the conversion of the South Manchuria Railway into a broad gauge greatly stimulated the exportation of these staple commodities, which during six months ending March, 1909, reached 16,200,000 yen. As a commercial metropolis of Manchuria, Tairen is bound to become a strong rival of Newchwang, and as a Pacific terminus of the great Siberian system, it has advantage even over Vladivostok. Not only must Vladivostok combat the ice king during winter months, but it is too far, to become an emporium of importance, from Hongkong and Shanghai, and other great commercial centres of China.

As regards the exploitation by Japan of Manchurian resources, we must describe the coal mining at Fushun and the lumbering industry on the Yalu River. The Fushun coal mines, though bequeathed by Russia as a part of the railway concession obtained from China, have been opened by the Japanese almost anew, for the old equipment and methods of digging were found entirely unsatisfactory. Thus Japan has already_expended 
$3,200,000$ yen for their improvement, and is to expend $5,800,000$ yen more until they are in satisfactory condition. But the expenditure is thoroughly justified, as the daily output has already reached 2,000 tons. When the new equipment now in the course of installation is completed, the daily output will, it is estimated, amount to 6,000 tons. The coal field is ten miles long. The width of the workable deposits measures at least a mile, and the thickness of the seam ranges from a hundred and twenty to a hundred and seventy-five feet. The amount of coal contained in the belt is, at the most conservative estimate, placed at eight hundred million tons.

As we have already stated, the Fushun mine as well as a few other mines were ceded to Japan by Russia, and the Chinese government by the agreement of December, 1905, tacitly recognized the validity of the cession. But the details of these mining concessions had by no means been clearly defined between China and Russia. The Eastern Chinese Railway never paid any royalty or tax on the output of the mines, neither did it compensate the original Chinese operators for what they had invested in the mines; and it is not at all certain that China ever protested against Russia about these matters. So, also, with regard to the extent of the mines. The Russian company worked many seams here and there over a wide district without China uttering a word of complaint. But as soon as Japan undertook to operate the mines China began to put forward a hundred and one complaints and protests. She would say she never forfeited the right to tax the mines; she would complain that she never agreed to let the Eastern Chinese Railway Company work so extensive a field as it actuaily did; she $r$ would demand an unreasonable amount of compensation 
for the investment made by Chinese operators before the coming of the Russians-an investment whose extent it is no easy task to ascertain since the original equipment was all but destroyed by Russian operators. These complaints and remonstrances are thoroughly characteristic of China's attitude towards a nation to which she owes a debt of gratitude for the recovery of a vast country of 360,000 square miles from the hands of a ruthless usurper. Yet Japan has had no intention of dealing with China in a high-handed manner as did Russia, and has consistently shown a willingness to settle all questions in an amicable manner. It is in consonance with this attitude on the part of Japan that the Chino-Japanese Agreement of September 4, 1909, was concluded, solving all questions relating to the coal mines in a manner satisfactory to China. It provides that the Japanese government, respecting China's sovereignty in the mining districts, shall pay to the Peking government a tax upon coals produced in the Fushun and Yentai coal mines, the rate of such tax to be determined in a separate arrangement upon the basis of the lowest tariff for coals produced in other mines in China; and that the extent of the mines, as well as other details, such as the compensation of the previous operators, shall be arranged by commissioners specially appointed for that purpose.

In pursuance of Article 10 of the Chino-Japanese Treaty of December, 1905, the two countries signed in May, 1908, a fresh agreement providing for the organization of a Chino-Japanese joint company to fell the timber on the Yalu. The capital of the company is $3,000,000$ yen, contributed equally by Japanese and Chinese subscribers. The forest reserved for the use of the company is sixty Chinese $l i$ (about twenty-two miles) 
in width, and extends over that part of the Yalu River between Mao-erh-shan and what is known as the Twentyfourth Valley, near the head waters of the stream. The area thus marked out comprises $65,000,000$ square feet. The duration of the company is fixed at twenty-five years, which may be prolonged only with the permission of the Chinese government. While it is presided over by the Chinese magistrate (taotai) of the district, its business is under the management of two directors-general, appointed one each by the Chinese and Japanese governments. Formerly the natives felled the timber in a most primitive fashion, and yet they were able to float down the river about I,500,000 eight-foot logs annually. With the installation of sawmills by the company, the criminally wasteful methods of the natives, involving an estimated unnecessary loss of thirty-five per cent. in the squaring of the logs, has become a thing of the past, and the Yalu timber promises to become the premier product of Southeastern Manchuria. Although the company's equipment is not yet completed, its gross receipts for I909 were 569,000 yen, while its expenses were 318,000 yen. This leaves a balance of 251,000 yen, which is equivalent to a little over seven per cent. interest on the capital invested. The output of the timber does not yet exceed fifteen million lien (a lien is an eight-foot log), but this will be greatly increased when the company has completed the installation of new equipment. The cutters sail up the river in September, and work during the winter. In May rafts are let down the stream to Antung, a distance of 360 miles. As there are many cataracts and whirlpools to contend with, it takes three to six months to reach the destination. Not only does the present state of the river cause a great loss in timber, but 
it results in many fatalities to human life. To make the navigation safer the company has commenced to improve the river bed.

As an indication of how scientifically and systematically Japan is studying the natural resources of Manchuria, we may call attention to the Central Laboratory at Tairen. Originally planned by Baron Goto, formerly governor of the South Manchuria Railway, now Minister of Communications, this scientific establishment is maintained at an annual expenditure of 60,000 yen, and is directed by one of the ablest scientists of Japan. Here ores from various parts of the country are tested, and here experiments are made to produce useful articles from the agricultural products of Manchuria. The laboratory is open to the use of foreigners for a nominal charge to cover the actual cost of chemicals and other materials consumed.

Now we must consider the Japanese railways. The main Japanese line from Tairen to Chang-chun, with a mileage of 436 , and the branch lines to Port Arthur, Newchwang and the Fushun coal mines, totalling seventysix miles, have been altered from a forty-two-inch track to a standard gauge of four feet eight and one-half inches and are equipped with American rolling stock. In this reconstruction work the South Manchuria Railway Company has already bought of America railway materials amounting to $\$ 6,722,000$. The most difficult problem for this Japanese railway was that of the connection with the Eastern Chinese Railway of Russia. Immediately after the war it seemed Russia's tactics to cripple the South Manchuria Railway and prevent the growth of Tairen by refusing to establish any coöperation with Japanese railway, thus hoping to make Vladivostok the only eastern terminus of the Siberian Railway. It was therefore 
no easy matter to induce Russia to make any satisfactory arrangement for through traffic between her own and Japanese lines. Without such an arrangement the South Manchuria Railway must lose much of its importance as a main artery of the world's trade and communication. It was with a view to solving this question that Baron Goto visited St. Petersburg in May, 1908. The visit resulted in the removal of much of the inconvenience which the South Manchuria Railway had endured in the lack of Russian coöperation. As the consequence of further negotiations held at Tokio last year between Mr. Wentchel, vice-governor of the Eastern Chinese Railway, and Baron Goto, harmonious traffic relations between the two railways have been assured.

Another Japanese line which promises to eclipse, in importance and interest attaching to it, even the main line of the South Manchuria Railway, is that between Mukden and Antung with a length of 189 miles. At present the line is still that wonderful little twenty-nineinch track, which, improvised by Japanese military engineers, overcame the Russian forces in front of it by the weight of lead and stores which it belched forth at them from the rail head. Although a splendid sample of military engineering, it is too slight to have any serious commercial importance. As such a narrow track is too dangerous for night traffic, it takes under the present schedule two long weary days of discomfort to make the 189 miles.

But this unique line will soon become a thing of the past, as the South Manchuria Railway Company, in pursuance of an article in the Peking Treaty of December, I905, is now reconstructing it. To link this line with the Korean Railway, a bridge, 3,1 82 feet in length, will be 
built over the Yalu River at an estimated cost of 2,500,000 yen. Evidently Japan expects to make this line one of the most important highways of commerce and travel, for it affords not only the quickest but the most diversely interesting route from Siberia to Japan, passing, as it does, through picturesque scenery which one misses in Siberia and other parts of Manchuria. When the bridge and the new rails have materialized, it will be possible to travel from Harbin to the Mikado's capital through Korea in some ninety hours, and from Mukden in seventy hours. Or to view the matter more broadly, the line is destined to form a link in the long chain of railway communication which will stretch from London to Tokio, with short breaks at the Straits of Dover and the Straits of Korea, thus bringing England within a fortnight by rail of Japan.

The Antung-Mukden line will be owned by Japan for fifteen years from the date of the completion of the reconstruction work. At the expiration of that term the line will be sold to China at a price to be determined by appraisement of all its properties by a foreign expert who will be selected by both parties concerned.

Before leaving the Japanese railways we must note the proposed Kirin-Changchun line in which Japan has much interest. In accordance with an agreement set forth in the protocols to the Peking Treaty of December, 1905. China and Japan concluded on April 15, 1907, a convention providing that the Chinese government, being about to construct a railway line from Kirin to Changchun, agreed to borrow from the South Manchuria Railway Company one-half of the capital needed for this work. The amount of the loan was later fixed at 2,1 30,ooo yen, redeemable in yearly installments in twenty-five 
years. In other essentials the loan contract is similar to that for the Imperial Railways of North China, financed by England. It is expected that the construction work will be completed by the end of I9I2.

In connection with the Kirin-Changchun road it is important to note that this line will ultimately be extended to Hoi-ryong on the Korean border, where it will effect a junction with the Korean Railway leading to Chongjin, a port on the Japan Sea. The "Chien-tao Agreement " of September 4, 1909, has the following provision:

"The government of China shall undertake to extend the Kirin-Changchun Railway to the southern boundary of Yenchi and to connect it at Hoi-ryong with a Korean railway, and such extension shall be effected upon the same terms as the Kirin-Changchun Railway. The date of commencing the work of the proposed extension shall be determined by the government of China, considering the actual requirements of the situation, and upon consultations with the government of Japan."

At present the Korean town of Hoi-ryong mentioned in this agreement is connected with the port of Chongjin by means of a military railroad of fifty miles built by the Japanese during the war with Russia. But in the event of China undertaking the extension of the Kirin Railway to Hoi-ryong this military railway will be reconstructed so as to facilitate its connection with the Chinese line. When these two lines materialize, the provincial capital of Kirin and its surrounding district will be in direct communication with the South Manchuria Railway on the one hand, and on the other with one of the most promising ports on the Sea of Japan. As I have said in the foregoing chapter the city of Kirin, being in the heart of a vast lumbering country, is so noted for 
junk building that it is called the "inland dockyard" of Manchuria. Yet this town of so great a commercial importance has been practically out of touch with the principal arteries of trade except by the extremely imperfect means of cart and of junk traffic over a tributary of the Sungari River which is unnavigable for the greater portion of the year. The advent of railway which will bring that region into close contact with the main route of the South Manchurian system and the Sea of Japan, cannot fail to stimulate its industry and open up its rich resources hitherto undeveloped. While this proposed railway will be legally owned by the Chinese government, Japan will have supervising authority over its traffic, as half of the money required for its construction is to be borrowed from Japan. As to the details of the method of supervision, they will be decided upon between China and Japan along lines followed by England in financing Chinese railways.

The Chinese line between Peking and Shang-haikwan extends itself into Manchuria, reaching Shin-min-tung, one of the important inland towns in the Liao Valley. These lines are officially called the Imperial Railways of North China, their Manchurian section measuring some 280 miles. Financed by English capitalists this system is still under British supervision, the method of which is to be adopted by Japan in connection with the Changchun-Kirin and Kirin-Hoiryong Railways we have already described. Briefly, the British method is this: the Chinese government is required to furnish capital sufficient to show a reasonable margin for the security; a British engineer-in-chief and a British accountant are included among the officials responsible for the administration of the system. 
In addition to the lines just described, the Chinese system in Manchuria includes a line of thirty-six miles between Mukden and Shin-min-tung. Originally this line was a military railway, built by Japan during the war with Russia, but in April, 1908, China purchased it for $\mathrm{I}, 600,000$ yen, upon the condition that she would borrow from the South Manchuria Railway Company, for a term of eighteen years, one-half of the sum required in reconstructing that portion of the line lying east of the Liao River, i.e., 32,000 yen. The line, having already been converted into a permanent standard track, connects with the South Manchuria Railway at Mukden.

Now, we are in a position to consider the Russian railways in Manchuria. That portion of the Eastern Chinese Railway which runs through Manchuria from Man-djulia on its western and Pogranichnaya on its eastern border has a length of some 920 miles. At Harbin, the Russian capital in Manchuria, this main line sends forth a branch of 147 miles, which at Chang-chun joins the main line of the South Manchuria Railway. As has been noted in the foregoing chapter, China, by the agreement of 1896 , reserves the right to take over, at the end of thirty-six years from the time of completion of the main line, $i . e$, 1903, the line entire on refunding to Russia all the outlays made on it. Should she fail to avail herself of this privilege, she has the alternative of taking over the railways without compensation at the end of eighty years from the above specified time. With the exception of the AntungMukden line, the Japanese system in Manchuria must also conform to these conditions.

The railway is the source of Russian influence in Manchuria. Deprive Russia of the iron road, and she will have no foundation left her in the Three Eastern Provinces. 
And yet this railway itself, viewed from a commercial point of view, has been an utter failure. The Eastern Chinese Railway has never hit upon a working basis, its balance sheet showing even at present an annual deficit averaging more than $\$ 10,000,000$. When Russia first constructed the Manchurian railways she, in spite of the heavy drain they made upon her treasury, consoled herself in the hope that the economic development of Southern Manchuria might some day reach a stage wherein the Eastern Chinese Railway might be enabled to place itself upon a paying basis. Russia's only hope for the possible recuperation of the enormous loss she had been enduring lay in South Manchuria, rich in mineral and agricultural resources. With the cession of the southern section of her Manchurian railways this cherished hope has been deprived of all possibility of realization, and the financial strain of the Eastern Chinese Railway has been growing harder and harder. It was undoubtedly with this unfortunate fact in view that the Paris Temps suggested not long ago that Russia dispose of her railway holdings in Manchuria.

But the abandonment by Russia of her Manchurian railways means the abandonment of all her Manchurian enterprises, political and commercial. Such a course Russia will never adopt until, if ever indeed, she has called into play all her abilities and energies in the effort to rehabilitate the financial condition of the Eastern Chinese railway. Early last year Mr. Kokovtseff, Russian Minister of Finance, made a tour of Manchuria with a view to ascertaining whether anything could be done to alleviate the financial difficulties of the railway. After a careful investigation this Russian statesman arrived at the conclusion that the following measures must be adopted, 
if the Eastern Chinese Railway was to avert the catastrophe towards which it had been drifting:

I. The semi-military management of the railway now in vogue must be replaced by a more businesslike method, giving the foremost consideration to the commercial side of the enterprise.

2. The number of railway guards, whose maintenance has been the main cause of the financial strain of the company, must be reduced to a great extent.

3. Heretofore the military officers attached to the railway have been receiving their salaries both from the War Department and from the railway company. This practice must be stopped, and the officers must be paid either by the company or by the government.

4. Women and superannuated officials with whom the company is at present overburdened must be dismissed, their places to be taken by younger and abler officials.

Whether this recommendation will, in the face of the stout objection of the military clique, be put into practice, we have yet to see.

In connection with the railways it is important to note the land acquired by the Russian and the Japanese railway authorities. The Russo-Chinese railway agreement of September, I896, provides that the railway company has the privilege to acquire without compensation any state land required for constructing, managing and protecting the line. Where land is privately owned the company must provide funds for compensating the owners at market rates. All lands thus acquired are exempted from land tax, and " as soon as they come under the management of the company, they may erect thereon any buildings and carry on all kinds of work." In virtue 
of this provision Russia obtained extensive tracts of land at important points along the railway. Of these lands those lying on the lines ceded to Japan, amounting to sixty-five square miles, were naturally handed over to the Japanese. In addition to the lands thus obtained, Japan has purchased 3,429 acres, or 5.36 square miles from Chinese landowners. Thus the South Manchuria Railway possesses at present some 45, I 56 acres of land, or about 70.54 square miles. Of this total about 5,486 acres are within the leased territory of Kwan-tung. Of the remaining 39,670 acres outside the leased territory, Liao-yang has I,I 57 acres, Antung 1,258 acres, and Mukden and Chang-chun 1,239 acres each, while the rest is distributed among other minor towns. These railway concessions are in a sense "settlements," where Japanese maintain their residence and business quarters. The South Manchuria Railway Company leases the land to those desiring to establish themselves within the concession; in many instances it builds houses to let.

The Russian railway concessions are on a more extensive scale. The entire land belonging to the Eastern Chinese Railway covers an area of 328,720 acres, or 513.63 square miles. The following table shows the distribution of the land in Russian control :

In Hei-lung-kiang Province :

Depots - - - -

Other lands

Along the rail

In Kirin Province :

Depots

Along the rail

At Harbin

$$
\begin{aligned}
& \text { - } \quad \text { - } 124,970 \text { acres } \\
& \text { - } \quad \text { - 71,328 “ } \\
& \text { - } \quad 9,9836
\end{aligned}
$$

- $\quad 84,967$ ،

$\begin{array}{r}84,967 \text { ، } \\ -\quad 5,075 \text { \% } \\ \hline\end{array}$

Total - - - - 328,720 “ 
The concession at Harbin alone measures more than 32,397 acres, or 50.62 square miles, lying astride of the Sungari River. It is said that this vast stretch of land, which cost Russia 400,000 rubles in purchase money some nine years ago, is now worth a hundred millions. This is not difficult to understand when it is noted that where there was in the winter of 1897 but a solitary Chinese village, the city of Harbin rose phœnix-like, and is now reputed to be one of the most populous European cities in the Far East, having at present some 80,000 Russian civilian inhabitants. The Harbin Railway land as well as those at other points may be acquired on special leasing terms from the railway authorities in regular lots.

While Chinese sovereignty is ostensibly respected within the concessions, these railway lands constitute an imperium in imperio. Not only do they enjoy immunity from taxation by the Chinese authorities, but the preservation of law and order therein is intrusted "s to police agents appointed by the (railway) company." Under such conditions it is but natural that many delicate questions should arise as regards the respective jurisdictions of the local Chinese authorities and the railway administration. In the spring of 1908 the American consul at Harbin had to protest against Russian measures, requiring foreign residents within the railway concessions there to pay taxes to the Russian authorities. This step the American consul interpreted as the violation of Chinese sovereignty, and his protest aroused at the time much sensation in the diplomatic world in the Far East.

In order to avoid such complications China and Russia signed on May I I, I909, an agreement, in which Russia reasserts her intention to respect China's sovereignty in 
the railway zone. The novel feature of this fresh agreement lies in the provision for "self-governing" councils to be organized in important towns along the railway. No national distinction is to be made as to the franchise, all inhabitants, with certain properties within the railway concession, being qualified to elect councillors. The council thus organized will be a deliberative body; the executive body is to consist of three members of the council, namely, the chairman, and one nominee each of the governor of the Eastern Chinese Railway and of the director-general of the Foreign Affairs Department of China. This Chinese director-general should not be confounded with the Foreign Minister or, to use Chinese nomenclature, the president of the Board of Foreign Affairs. The former, though appointed by the Chinese government in accordance with the railway agreement of I 896, is paid by the Eastern Chinese Railway Company, his duty being to supervise the task delegated to the company by China, to investigate from time to time the accounts of the company with the Chinese government, and to manage all business between the company and the Chinese government or any Chinese officials, either central or local. Heretofore this apparently important Chinese functionary discharged his duties oniy in perfunctory fashion. Whether Russia will, under the new arrangement, allow him to assert his rights is yet to be seen. While the new agreement makes no national distinction as to the franchise, the council will consist almost exclusively of Russians, who form the majority of the population within the railway concessions.

The Manchurian Railway inevitably suggests the railway guards whom Russia and Japan, in virtue of the Portsmouth Treaty, have the right to maintain. By the 
evacuation agreement entered into between the Japanese and Russian commandants in the field on October 30, 1905, the maximum number of such guards was fixed at fifteen per kilometre. At the latest computation the Russian force of railway guards consists of four brigades, which roughly speaking comprises fifty-five companies each of infantry and cavalry, and a company of artillery. As a Russian company usually consists of about two hundred and thirty officers and men, the entire Russian force would be about 26,680 . As against this force Japan maintains only a division and six battalions, numbering about 8,800 officers and men.

That a reasonable number of guards are absolutely necessary there is no room to doubt, as the entire country is infested with bandits, who ever and anon raid the trains and attack the travellers. But the maintenance of unnecessarily large forces is regarded by China as an affront to her sovereign rights, and it is much to be desired that both Japan and Russia see to it that the number of their railway guards is kept within reasonable limits. The Chino-Japanese Treaty of December, 1905, provides: "When tranquillity shall have been established in Manchuria, and China shall have become herself capable of affording full protection to the lives and property of foreigners, Japan will withdraw her railway guards simultaneously with Russia." How soon that time will come it is impossible even to conjecture.

As I write this chapter an auspicious report comes from the Far East, once again vindicating Japan's faithfulness in adhering to the principle of the "open door" -it is the news of the opening of Port Arthur to international trade. That Gibraltar of the Far East, whose fortification cost unnumbered rubles and called into play 
all the talent and ingenuity of which the Russian military engineers were capable, has remained just as the destructive power of Japanese shells left it at the end of the historic siege. The Japanese have not spent a single $y e n$ for the repair of the destroyed fortifications. That grim “ 203 Meter Hill," that sullen Kei-kwan-zan, with batteries shattered and casemates demolished, tell to-day, as vividly as on the morrow of the surrender of the besieged army, the tales of wonderful heroism displayed by both the attacking and the defending forces. Obviously Japan does not think it worth while to fortify Port Arthur, and now she has made it a commercial port by throwing its doors open to foreign trade. It is a sensible measure, and Japan ought to be congratulated upon having already put it into execution. The innovation will materially contribute to the prosperity of Manchuria, with which all trading nations are seriously concerned. As I have said, Tairen is supposed to be a port free from ice, yet when the weather is calm during the intense cold of the winter months, the harbor is liable to freeze, for a short time at all events. Then again, when a blizzard blows the water is so agitated that the vessels are forced to suspend the loading and discharging of cargo. The breakwater now in course of construction will protect the harbor from high waves liable to be stirred up by blizzards, but it is not at all certain that this precaution will not result in the freezing of the water. The opening of Port Arthur will make up for this precarious state of the Tairen harbor. Protected by winding high hills, the harbor of Port Arthur is not disturbed by strong blasts for which Manchurian winters are noted. What is more important, it is the only Manchurian port which is really free from ice. Its only drawback is that 
the entrance to the harbor is rather too narrow to permit the free movement of large steamers, but this inconvenience can be easily remedied by cutting a canal between the harbor and Pigeon Bay, so that steamers may come in by the present entrance and depart by the canal. All things considered, Port Arthur surpasses Tairen as a commercial port, and it is to be hoped that its opening to international trade will greatly enhance the value of the South Manchuria Railway. 


\section{AMERICAN POLICY IN MANCHURIA}

MERICAN policy in Manchuria, and indeed in
China, may be summed up in what is commonly
designated the "open door," having for its corollary the maintenance of the territorial integrity of the Celestial Empire and equal opportunity for all nations in commerce and trade in that country. Nowadays every one speaks of the "open door": few know how the doctrine originated, and what it exactly means. The "open door" principle is in reality an application of the ChinoAmerican Treaty of 1868 secured through the efforts of Anson Burlingham, but for our present purpose it is not necessary to go back to the classic period of Burlingham -suffice it to begin with the late Mr. Secretary John Hay, who invested the "open door" with a more definite meaning according to the needs of the times.

The name of John Hay has indeed been so closely associated with the "open door" that the public has forgotten that the doctrine really originated in England. When Germany seized Kiao-chou in I898, England felt the necessity of adopting a policy which might serve to safeguard her interests in China. She discerned an obstacle, if not a menace, to her interests in a movement which aimed at the vivisection of the hoary empire into various spheres of influence. By upholding the principle of equal opportunity for all foreign nations, England thought she could maintain her position, which was 
practically impregnable unless attacked by means of political intervention such as was manifested in the establishment of a German sphere of influence in the province of Shan-tung. Unfortunately, however, the decrepit condition of China had begun to be evident, and the German occupation of Kiao-chou seemed but the entering edge of the wedge which was to split the huge empire. England was forced to take cognizance of this unhappy situation, and she began to be skeptical as to the availability of the "open door" doctrine as the means of securing the purpose for which it was invented. It must have appeared to British statesmen more advisable to accept the inevitable, and be ready to fall in line with the chancelleries of continental powers which were contemplating the slicing of China. For a while Downing Street seemed to be carrying water on both shoulders, apparently oscillating between the "open door" and the sphere of influence.

Thus abandoned by its sponsor, the "open door" doctrine was on the verge of oblivion, when a new actor appeared upon the stage of world politics, determined to save the forsaken doctrine. The new character was John Hay. That illustrious American Secretary of State, with keen insight and broad statesmanship, perceived in the abandonment of the "open door" the grave possibilities not only to China but to the United States. Mr. Hay lost no time in acting upon his conviction. He instructed, at various times from September 6 to November 17, 1899, American Ministers in France, Germany, Great Britain, Russia, Italy and Japan to request the governments of said powers to give formal assurances that the principle of the "open door" would be strictly adhered to, even where a sphere of influence was actually 
established. The meaning of the "open door," as given in these instructions, is this :

First. That no power will in any way interfere with any treaty port or any vested interest within any socalled "sphere of influence or interest" or leased territory it may have in China.

Second. That the Chinese treaty tariff of the time being shall apply to all merchandise landed or shipped to all such ports as are within said sphere of influence (unless they be free ports), no matter to what nationality it may belong, and that duties leviable shall be collected by the Chinese government.

Third. That no power shall levy any higher harbor dues on vessels of another nationality frequenting any port in such sphere than shall be levied on vessels of its own nationality, or any higher railroad charges over lines built, controlled, or operated within its sphere on merchandise belonging to citizens or subjects of other nationalities transported through such sphere than shall be levied on similar merchandise belonging to its own nationals transported over equal distances.

Such, then, is the exact meaning of the "open door," as conceived by Mr. Hay and accepted by the powers. By the time the American memorandum was addressed to the powers, Russia had leased the Kwan-tung Peninsula, Germany had established herself in Kiao-chou, and even Great Britain, which had championed the "open door," had felt it expedient to recognize by a formal agreement the exclusive right of Germany to enjoy in Kiao-chou and the contiguous sphere of influence certain privileges, more especially those relating to railroads and mining enterprises, in acknowledgment of which Germany, on her part, recognized the British sphere of in- 
fluence in the Yangtse Valley. Yet all these powers felt constrained to put themselves on record as approving the American proposal, which was obviously just and in principle irrefutable. If England, Germany and Russia would not dare refuse the proposal, why should France, Japan and Italy object to it? The "open door" had smooth sailing, and within a few months after its launching all the powers interested in China became apparently pledged to its cause.

Meanwhile Mr. Hay's programme was in his own country received with mingled commendation and denunciation. Some of the American publicists and statesmen regarded this move of $\mathrm{Mr}$. Hay's as a dangerous departure from the traditions of the United States. He was accused of committing his country to a policy " impossible of attainment by our own independent action, and if pursued in common with other powers fraught with the gravest possibilities of those international entanglements with European nations, which it is our historic policy to keep out of." Yet, considering the condition existing in China at the time and in the face of what the doctrine has achieved, there can be no doubt but that the "open door" programme was best adapted to the interest of the United States. At the time when the "sphere of influence" doctrine was on the ascendant, America had no foothold in China. Should European powers agree to slice up China among themselves, where would the United States come in? Russia would have taken Manchuria and Mongolia; Germany a vast stretch of territory lying south of the Russian sphere; Great Britain the Yangtse Valley, Thibet and a goodly portion of Southern China; and France the provinces adjacent to her Tongking possessions. This would have left nothing 
for the United States, for she was in no position to put forward any territorial claim in China even if she desired to. By an undivided China, therefore, America had much to gain and nothing to lose. With the doors of China left open, America would be able to push her trade, maintaining, at the same time, the integrity of the empire. I hazard no theory that it was merely the protection of America's own economic interest which prompted Mr. Hay to propose the "open door," but I am, with Mr. Thomas Millard, inclined to believe that he is but an amateur in international affairs who thinks America was actuated to put forward this policy from purely altruistic motives.

Secretary Hay's " open door" programme was neither too ambitious nor too political to conform to the national spirit of the times. America had already been inclined to play fast and loose with her traditional policy of isolation. The annexation of Hawaii was the first step towards her political and economic expansion in the Pacific and beyond. Then came the occupation of the Philippines, and with it was tolled the knell of those happy days when American statesmen and people, contented with the enormous wealth which nature bestowed upon them, harbored no idea of territorial expansion. The call of empire had been heard, and the great republic responded to it with the booming of cannon that flashed from Admiral Dewey's flag-ship in Manila Bay. Once her traditional policy was so radically altered, it was but natural that American statesmen, if not people, should keep their eyes intently fixed upon the Orient. As the years rolled on, it became evident that the American nation came definitely, if unconsciously, to embrace imperialism, which is at once the glory and nemesis of 
modern times. The voice of imperialism is no voice of humanity: rather it is a gospel of commercialism and self-aggrandizement, and the imperialism of America is no exception to the general rule, however anxious some Americans may be to have us believe that American activities in the Philippines and China are perfectly disinterested. It is the animating desire to become great among the nations, to be respected in the council of the powers, to consolidate her foothold in the Far East, to secure market for the products of her ever-expanding industry -it is this desire which impels America to greater and greater activities in the Orient. Perhaps this zeitgeist is most clearly and ably expressed by no less a statesman than Theodore Roosevelt when he says :

"The Mediterranean era declined with the Roman Empire and died with the discovery of America. The Atlantic era is now at the height of its development and must soon exhaust the resources at its command. The Pacific era, destined to be the greatest of all, and to bring the whole human race at last into one great comity of nations, is just at the dawn. Man, in his migration westward, has at last traversed the whole round of the planet, and the sons of the newest West now stand on the Pacific Coast of America and touch hands across the greatest of oceans with those ancient races of Asia which have from time immemorial dwelt in their present seats. It is the fate of the American nation to be placed at the front of the turmoil that must accompany this new placing of the peoples. I believe the contest will be friendly and peaceful; it surely will be if we keep ourselves so strong that we do not have to fear wrong, and at the same time scrupulously respect the rights and feelings of others."

Verily it is the conviction of the American nation that 
it is destined to play the rôle of the star actor in the Far Eastern drama upon whose scene the curtain has only gone up. How much more simplified will the matter be, if other nations only do not cherish the same desire and the same conviction. Alas! nations of the old world are not likely to exalt America to the altar of international supremacy, and with meekness and reverence follow the lead of the Republic in the disposition of the Far Eastern question. Be that as it may, men like John Hay and Theodore Roosevelt pointed the way, and men like William H. Taft and Philander Knox are now striving to follow it. Whether Mr. Taft and Mr. Knox are playing their part successfully and ably is, of course, another question.

I have given the meaning of the "open door" as defined by Secretary Hay, and I ask that the reader keep it in mind as he follows America's fresh activities in Manchuria. For several years after the acceptance by the powers of Mr. Hay's "open door" programme Russia made a feint of abiding by it, evading it at every point at the sacrifice of the interests of other nations. During this period America and Japan were naturally drawn closer, as the Mikado's Empire felt even more keenly than did the United States the necessity of preventing the Russian absorption of Manchuria. America, of course, did not even so much as dream of ever going to fight Russia for her Manchurian trade, but she was ready to exercise a highly benevolent neutrality towards any nation which the Manchurian situation might bring into collision with Russia. Both Japan and America protested on more occasions than one against the Russian method in Manchuria, but each protest met only with rebuff, if nothing worse. In the strenuous effort to 
hold the doors of Manchuria open-doors that had already virtually been slammed-Japan and America forced China, in the face of Russia's stout objection, to open the Manchurian towns of Mukden, Antung and Ta-tung-kou. But all such palliative measures were utterly powerless to stop the mighty snowball which the Russian bear set rolling down from the frozen shores of Baikal on to the Yellow Sea. The result was the Russo-Japanese war.

With the termination of the war America's attitude towards Japan changed radically. The romance and poetry of the mighty conflict were destined to fade away as considerations of self-interest again possessed the American mind. The beginning of this change of American attitude was noticeable even when the peace conference at Portsmouth was proceeding. In a strange, vague, unconscious manner, the ardor of sympathy which the American people had extended to the Japanese during the war seemed to cool even to such a degree that Russia was virtually substituted for Japan in the interest and good wishes of the nation. The reason for this change of sentiment and opinion is not beyond understanding. Nations are essentially selfish in that they think of their own interest first and foremost. America was actuated to extend moral support to the Mikado in his struggle with the great White Czar by the belief that with the Muscovites driven out of Manchuria American trade there would be accorded an ample chance to forge ahead. The average American, of course, did not think so far ahead, but supported the Japanese chiefly by reason of sentiment. But time for sentiment was soon past, and the average American is now led by the opinion of those who look at the Manchurian question from the point of view of America's commercial interest. Even 
when the outcome of the Portsmouth conference was yet uncertain, the New York Times clearly foresaw this inevitable change of America's attitude towards Japan, and made the following pertinent remarks :

"Entertaining for us the most sincere sentiments of affection and respect, Japan as she works out her present ambitions will set up in the East a commercial Monroe doctrine, and by the simplest process in the world, the process of making and selling goods so cheap that we shall be unable to find any buyers. . . . If it be true that price makes the market, another terrible taking down awaits the Western world's vanity, and this time its pockets will come into the reckoning. If there be a yellow peril, undoubtedly it is a commercial one, and of the nature we have delineated here. . . . Every advance she makes towards securing for herself the Chinese market will provoke European opposition, and in particular will rasp the tenderest nerve of her firm ally, Great Britain. It would be illogical-worse, it would be humiliating - to set up commercial restriction against a nation that makes a virtue and a speciality of the 'open door.' But in what other way, should China not be partitioned, will the Jap, with his excellent cheap goods, be kept out from markets to which his admission would be equivalent to the exclusion of the rest of the world?"

Whether Japan is so quixotic as to entertain the ambition to set up a "commercial Monroe doctrine" in the Far East is a question we care not to discuss. What is essential is the emphasis which the Times laid upon the Western world's dislike of Japan's commercial advance in the Asian continent, which accounts for the alienation of Western sympathy from the insular nation. As the Japanese promoted their commercial interest in Manchuria with 
marked success, American trade interests became apprehensive as to whether they would be able to hold their own against Japanese competition. The apprehension soon turned into suspicion that Japan's success was due to the discriminative measures which she adopted against foreign interests. The trouble was, they could never tell what such discriminative measures were. If they only could do that, Japan would be but too willing to straighten things up to suit the American traders. But how could they? Discrimination there was really none. Japan benefited herself, as we shall presently see, only by taking advantage of the natural laws of trade, which were favorable to her. In the case of Russia before the war there was substantial evidence of hindrance and obstacles which she laid in the path of American interest; in the case of Japan discrimination is not proved, but merely suspected. So far as I am aware, the only charges, which have been made with some semblance of specification, are that Japan applies to Japanese goods railroad and steamship rates much lower than are applied to foreign merchandise. Yet the critics who advance such complaints unmistakably admit that there is no evidence with which to support such charges. Probe however deep they may, they will never be able to find such evidence, for they, with all their creative genius, cannot produce anything from nothing.

By 1908 the American suspicion had become so intense that the Tokio government felt constrained to take some measure to alleviate it. Thus the diplomatic notes of November of that year were exchanged between Tokio and Washington, asserting that the two governments were " animated by a common aim, policy and intention" in the Pacific and in the Far East. The notes declared that: 
"It is the wish of the two governments to encourage the free and peaceful development of their commerce on the Pacific Ocean.

"The policy of both governments, uninfluenced by any aggressive tendencies, is directed to the maintenance of the existing status quo in the region above mentioned, and to the defense of the principle of equal opportunity for commerce and industry in China.

"They are accordingly firmly resolved reciprocally to respect the territorial possessions belonging to each other in said region.

"They are also determined to preserve the common interests of all powers in China by supporting by all pacific means at their disposal the independence and integrity of China and the principle of equal opportunity for commerce and industry of all nations in that empire.

"Should any event occur threatening the status quo as above described or the principle of equal opportunity as above defined, it remains for the two governments to communicate with each other in order to arrive at an understanding as to what measures they may consider it useful to take."

In entering into this understanding the Roosevelt administration, with Mr. Root as its Secretary of State, was no doubt sincere, and was willing to take Japan into confidence. But the cabinet had soon to change, and with it was gone Mr. Root. It seems tolerably clear that Mr. Root's successor, Mr. Knox, in dealing with the Manchurian question or the Central American question, has not exactly followed the line marked out by his predecessor in the State Department. It is not my place to criticize Mr. Knox's policy in Central and South America, but so far as his dealings with the Far Eastern questions are 
concerned, I am inclined to think that the Secretary of State has added very little to the prestige of American diplomacy. The Crane episode and his proposal for the neutralization of the Manchurian railways bear witness to this conclusion.

I have no intention to make apologies for that ephemeral minister to China, Mr. Charles R. Crane. Whether he was, as some observers think he was, led by the idea that he was the only choice of Mr. Taft to attach too much importance to himself, I do not know. What I do know is that Mr. Knox's manner of handling this diplomat was hardly calculated to add to his credit. If Mr. Crane was indiscreet in speech and unfit in other respects to fill the important post of a minister of a great republic to a foreign court, why not let him resign quietly without making so much ado? I fail to appreciate the wisdom of Mr. Knox in publishing a statement of such a nature as would surely provoke a retort from the dismissed minister. At any rate it was an unseemly squabble that passed between the Secretary of State and the deposed minister to China. It only resulted in exposing to the curious, gossipy world awkward family disagreements that ought to have been kept private, if a great nation like America was to maintain its dignity before the powers.

But the Crane episode is passed, and it is at least comforting to think that it is fast slipping from the memory of the public. What is infinitely more vital is Mr. Knox's scheme for the neutralization of the Manchurian railways. Here again our Secretary of State met with sarcasm and even ridicule in Europe, while Japan received the proposal with antipathy that bordered upon indignation. Nor is this surprising when it is considered that Japan sacrificed 
untold treasure and countless lives for the acquisition of her railways in Manchuria. As for Russia, she obtained her gigantic railway concessions in Manchuria by mere bullying or wily diplomacy; but the cost which her Manchurian venture has since entailed has been so enormous that she is driven to keep on playing the game in the hope of winning back what she has been losing. To Japan, her Manchurian railway holdings, though totalling only some 700 miles, meant a loss of 100,000 lives and 2,000,000,000 yen, which constituted the cost of a mighty war upon which she staked her very existence. In the face of such an appalling sacrifice she made, it may well be conceded that she has the right, as long as she conforms to the principle of the "open door," to operate her railways, so that the proceeds from the traffic may assist, if ever so little, in lightening her financial burden entailed by the war. For while the Eastern Chinese Railway of Russia is a heavy burden upon the Russian treasury, the South Manchurian Railway is yielding a fair margin of profit. As I have already stated, China has the right to buy up both the Russian and Japanese lines in Manchuria by 1939; then it may be opportune for America, should she still think the game is worth the candle, to propose the neutralization of these railways, or, what is simpler, to finance China so that the latter may purchase the lines for herself instead of neutralizing them. "But surely we can't wait so long; anything may happen before we are anywhere near 1939," you may retort. Yet Russia's intentions in Manchuria have undergone a marked change since the war, while China's foreign relations in general are no longer such as would allow any single power to absorb such a vast territory as Manchuria. As for Japan, she has repeatedly reassured the world of her sincere de- 
sire to respect China's sovereignty in the Three Eastern Provinces. You are, of course, at liberty to suspect that Japan is an arch-hypocrite; but if she is, she has not yet betrayed any sinister designs, which you fear may be behind her professed intentions. In the face of this fact, who can ask her to surrender her railways in Manchuria on the ground that she may use them for evil purposes? Can any one fail to see that such a proposal puts Japan in an extremely embarrassing position? She dislikes to turn down any formal proposal from a nation with which she entered into a sort of entente cordiale, yet she cannot stultify herself by accepting a compact based upon the hypothesis that she has no intention of fulfilling her engagements with China. If the spirit of the diplomatic notes, exchanged between Japan and America during Mr. Root's incumbency in the State Department, was lived up to, Mr. Knox should have sounded the Japanese government with regard to the feasibility of the neutraliza. tion scheme before submitting a formal proposal to the powers. Apparently Mr. Knox thought it better to permit the Root-Takahira notes to fall into innocuous desuetude, else he certainly would not have acted as he did.

Apart from the considerations I have mentioned, Russia and Japan had fairly sound reason for rejecting the Knox proposal-I refer to the fact that the two countries are solemnly pledged by treaty to abstain from using the Manchurian railways for military purposes. As I take it, Mr. Knox proposed neutralization mainly because the railways would thus be disabled for the transport of troops and munitions of war. If this be so, could not Russia and Japan promptly reply that so far as concerns their potentialities in war the Manchurian 
railways have already been neutralized? Then, again, there is the consideration that Russia's Amur railway, which, when completed, will circumscribe the Manchurian frontier, will enable Russia to muster any military force at all points within a stone's reach of Manchuria. As for Japan, she has no such advantage, yet she can easily descend upon Manchuria from her bases of operation in Korea. It comes to this, that, neutralization or no neutralization, neither Japan nor Russia would find any difficulty in swooping down upon Manchuria, if she should set her mind to do so. The more closely we scrutinize the neutralization scheme the more insuperable do the practical difficulties appear. After all, the only effective guarantee for China's integrity lies in her ability to regenerate herself.

Secretary Knox did not sit quiet under the rebuff of the neutralization project, but followed it up with a fresh project, which, if carried out, would be of more serious concern to America. This new project is that of constructing with American capital an extensive line of railway in Manchuria. Here again Mr. Knox is confronted by obstacles which seem well-nigh insurmountable. But before discussing the practicability of this scheme let us delineate the nature of the proposed railway.

The railway is to connect Chin-chou on the south and Aigun on the north, tapping the Russian railway at Tsi-tsi-har. Chin-chou lies on the main line of the Imperial Railways of North China, and is one of the important trade entrepots in Southern Manchuria. Tsi-tsihar is the capital of the province of Hei-lung-kiang, and is situated in the heart of Northern Manchuria. The distance between the two cities will be approximately 700 miles. Starting from Chin-chou the line will tap 
the northeastern corner of Chih-li, the metropolitan province of China, and following the trade routes farther north will traverse the eastern section of Mongolia until it reënters Manchuria and strikes the Eastern Chinese Railway near Tsi-tsi-har. At present the Liao River and the South Manchuria Railway are the greatest trade arteries for the produce of the far interior of Manchuria and Eastern Mongolia; and Chang-chun, the northern terminus of the South Manchurian line, is aptly termed the clearing-house of inland Manchuria, being the distributing centre for trade to and from Kirin, Hei-lungkiang and Mongolia. In travelling that region in winter one is struck with the wonderful sight of string after string of carts proceeding from north to south all heavily laden with the produce of the interior, including beans, tobacco, hemp, dressed pigs, skins and large droves of black pigs, which are either unloaded at various railway stations, or deposited in the numerous pawn-shops until the Liao River opens in the spring. But when once the Chinchou-Tsitsihar line is constructed much of this trade will inevitably be diverted to this new route. The line, morever, has the advantage of affording the shortest route from Europe to Peking and the great marts of commerce in China such as Tientsin, Shanghai, Hankow and Hongkong.

But, as I have already indicated, the ultimate terminus of this line will not be Tsi-tsi-har. It is the American plan to extend it as far as Aigun, on the Amur River, just opposite Blagovestchensk, the capital of the Russian province of Amur, made infamous by General Gribsky's wholesale massacre of 5,000 innocent Chinese in 1900. From a commercial point of view the Tsitsihar-Aigun section will be of little value, but it is strategical con- 
siderations which actuated America to plan its construction, as it will no doubt have the effect of safeguarding the northern border of Manchuria, which was constantly encroached upon by Russia. All in all the proposed American railway will measure some $\mathrm{I}, 000$ miles. The project, like Mr. Knox's ill-fated neutralization scheme, bears the mark of that bold spirit of speculation, which seems to be the impelling force of the American industrial world.

In the execution of this gigantic project America must overcome the objection which Russia has offered against it. It was also feared that Japan might join hands with Russia in the effort to prevent the construction of the railway, because of the fact that, in virtue of the protocol annexed to the Chino-Japanese Treaty of 1905, China relinquished the right to build any railway which might prove prejudicial to the interest of the South Manchurian Railway. But this apprehension has been dispelled by the announcement that Japan will indorse the project on the condition that China allow Japan to build a line to effect a junction between the South Manchurian system and the projected Chino-American line. On the other hand, Russian objection is of more vigorous nature. She contends that there is a treaty with China, in virtue of which she has the right to veto such a scheme as has been launched by America. To this China retorts that the privilege, which Russia claims she still enjoys, was virtually nullified by reason of the fact that Russia failed to protect her railways against the Japanese during the late war. Whether that treaty stipulation is binding or not, the fact remains that the proposed Chino-American line must tap, and make a junction with, the Eastern Chinese Railway, which cannot be done without Russia's 
consent. But the granting of such a consent would mean to Russia the abandonment of her cherished hope of making the Eastern Chinese Railway the trunk line in the great trans-continental system, and thus make the Vladivostok the first port for commerce and intercourse between Europe and the Far East. The Russian Railway and Vladivostok have already keenly felt the competition of the South Manchurian Railway and the port of Tairen. The addition of another line, whose advantages promise to eclipse even those of the South Manchurian Railway, seems certain to deprive the Russian line of much of its raison d'être.

Here it seems important to note British attitude towards the Chino-American project. In launching this project the Washington administration paid due respect to British interests in the region through which the line is to be built, and invited British firms to coöperate with the American syndicate which is to finance the railway. But England, on her part, is, by reason of her particularly cordial relations with both Russia and Japan, in honor bound to refrain from taking any active part in a scheme which runs counter to the interest of either one of these powers. This point was raised in the House of Commons on March 23, I9I0, when Sir W. J. Bull queried whether the cabinet's policy in the Far East would be modified so as not to obstruct Anglo-A merican interests. Replying to this question Sir Edward Grey, Minister for Foreign Affairs, said that Great Britain must pay due regard to the Anglo-Russian Agreement of 1899, which forbade her to accept the American invitation with regard to the Chinchou-Aigun Railway. Sir Edward added that to interpret this attitude as jeopardizing Anglo-American interests in Manchuria was an entire 
misapprehension, and explained that America had been kept fully informed of the British view of the matter, with which she was obviously satisfied.

Mr. Willard Straight, who resigned the post of A merican Consul-General at Mukden to become the adviser to the American syndicate which broached the Chinchou-Aigun Railway scheme, was in St. Petersburg in the effort to persuade Russia to indorse the project. Apparently his efforts were crowned with little success. Russia, instead of consenting to the scheme, proposed to the Chinese government that, as the alternative to the ChinchouAigun line, she be allowed to build a railway from a point on the Siberian line near Lake Baikal, by way of Urga and Kiakta, to Kalgan, where it will join the Chinese line leading to Peking. The concession for this line was secured some years ago, but was later virtually abandoned as its construction could not be justified as a commercial undertaking. With the launching of the fresh Chino-American scheme, however, Russia resuscitated the old concession, claiming that the Kiakta-Kalgan line is much preferable to the Chinchou-A igun line.

That America is quite anxious to carry out the Chinchou-Aigun Railway scheme is indicated by the change of its attitude towards Russia with regard to the payment of taxes by Americans residing in Harbin. In 1908 the A merican consul at Harbin protested against the Russian measure, requiring American residents within the Russian municipality there to pay taxes in the same manner as did the Chinese and Russians. The American government, indorsing the consul's action, consistently declined to recognize the validity of the Russian measure, until it launched the Chinchou-Aigun Railway project. It may have been merely a coincidence, but it is interest- 
ing to note that almost simultaneously with Mr. Straight's arrival in St. Petersburg as the representative of the New York syndicate interested in that railway scheme, America's attitude towards the taxation question in Harbin changed perceptibly. By the middle of June last, the Washington administration was willing to recede from its former position, and through Minister Calhoun at Peking instructed the American consul at Harbin not to remonstrate with the Russian authorities with regard to the taxation of American residents there. This concession on the part of America may not have had anything to do with the new railway scheme, but it is significant that the semi-official Novoe Vremya, commenting upon this new move of America's, refers to the ChinchouAigun Railway question in these words:

"The Chinchou-Aigun Railway concession, whose thin edge was directed against Russia, appears in a changed aspect as a subject for future negotiations, as Russia has no reason to distrust American enterprises in the Far East, once American hostility has been permanently abandoned."

American objection to the Russian measure above mentioned was based upon the assumption that it was in violation of Chinese sovereignty within the railway zone. But the apparently altruistic view, which America at first advanced with regard to the taxation question in Harbin, is now cast into the winds. And yet it is extremely doubtful whether America will ultimately secure what she has been coveting. So far as I am able to judge, Russian attitude towards the Chinchou-Aigun Railway question has not changed, in spite of the American compromise. 


\section{IV}

\section{CHINESE DIPLOMACY IN MANCHURIA}

$T$ the outset of the present discussion I con-
tended that China's attitude towards Japan has
been one of ingratitude and insincerity. It is a grave charge, and I feel in honor bound to prove it. That this point should be clearly brought home to the reader seems all the more desirable inasmuch as the American public, by reason of want of accurate information, has been led to believe that it is Japan, rather than China, which is really to blame in the disputes over various questions relating to Manchuria: It is regrettable that the Americans are utterly oblivious to the fact that China has been flirting with their country for the evil purpose of embroiling America with Japan. For a while China conspired to estrange Great Britain from Japan, but the mandarins failed to remember that the Anglo-Japanese alliance was established upon too solid a foundation to be affected by their transparent manœuvres. Her first designs having proved abortive, China has cast her coquettish eyes towards America. Woe betide those good, credulous Americans who really believe that China is wooing their country with all her heart and soul! In the hands of the mandarins America is like an inexperienced youth before a veteran courtesan. China has never taken any foreign nation into confidence, but has always plotted to make capital out of suspicion and distrust among foreign nations, thus hoping to balance the activities of one na- 
tion against those of another, and so to nullify the effects of both within her sphere. For this perverted method of diplomacy China alone is not to blame; more to blame are those Western nations which during the past half century exploited China at the expense of her own integrity and welfare.

What wonder that China, thus abused and maltreated these many years, is irrevocably wedded to the idea that foreigners are all creatures of fair mien but of evil spirit ? Yet the fact remains that this spurious idea often entails deplorable effects to China herself, and works serious mischief to those foreign powers which are sincerely anxious for the rehabilitation of her affairs. When a farmer attempted to rope up a shaky barrel in which a hen was sitting on a nest full of eggs, the silly fowl mistook him for a mischievous youngster and flew in his face. The fowl may have been innocent, but the farmer had to take proper steps to protect himself. Japan's attitude towards China with regard to the Manchurian question has been the attitude of the farmer who shielded himself from the silly hen. Let us see.

The characteristic Chinese method of diplomacy is most conspicuously exemplified in the case of the Shinmintung-Fakumen Railway controversy, in which China and Japan, and to a lesser degree England, were involved. For a while at least the controversy was, at the hands of the British and American press, made an occasion for censuring Japan's uncompromising attitude. When the history of the question, and the intrigues and designs involved in it, are clearly known, the public will be able to judge more intelligently whether or not Japan's position was justifiable in the light of fairness and equity.

In the spring of 1907 the Chinese government broached 
the scheme of constructing a railway line from Shin-mintung to Fa-ku-men in extension of the ShanghaikwanShinmintung section of the Imperial Railways of North China. The plan was so secretly made that Japan did not even suspect it until August of that year, when negotiations between the Peking government and the British firm of Pauling and Company for the construction of that railway were well under way. If China had entertained any respect for an engagement contained in the protocol annexed to the Peking Treaty of December, 1905, she would have abstained from conceiving such a scheme, or at any rate would have consulted Japan before taking any measures towards its execution. The engagement referred to reads as follows:

"The Chinese government engage for the purpose of protecting the interests of the South Manchuria Railway, not to construct, prior to the recovery by them of the said railway, any main line in the neighborhood of and parallel to that railway, or any branch line which would be prejudicial to the interest of the above mentioned railway."

Upon the strength of this provision the Tokio government warned the mandarinate government that the Shinmintung-Fakumen scheme would not be acceptable to Japan. The friendly warning apparently made no impression upon China, for the latter proceeded with the plan as if Japan had said no word about it. Japan, though chagrined by this arrogant attitude of China, was nevertheless patient enough to repeat the same warning in October in a kindly manner, only to receive an evasive reply thoroughly characteristic of China. Japan's magnanimity was not yet exhausted, and in November she for the third time reminded China of the above-mentioned en- 
gagement, in the same gracious manner as before. Instead of heeding this repeated warning the authorities at Peking secretly concluded a contract with Pauling and Company, almost simultaneously with the receipt of the third warning from Tokio. Secrecy so profound was maintained that it was only towards the end of January, 1908, that Japan detected the conclusion of the deal. Can a more flagrant case of discourtesy, spitefulness and treachery in diplomacy be imagined? Japan had acquired her Manchurian railways with an appalling sacrifice, which she braved on behalf of China as much as of herself, and the acquisition was unequivocally recognized and confirmed by China in the Peking Treaty of December, 1905. In the face of this fact, Japan was fully justified in requiring China not to build any railway which might prove inimical to the interests of the South Manchuria Railway. Suppose Japan had not dared to combat Russia, what would have become of Manchuria, and indeed of China? With the Three Eastern Provinces irretrievably lost to China, other powers would not have hesitated to follow the suit of Russia and slice for themselves such regions as they had fixed their covetous eyes on. The defeat of Russia at the point of the Japanese bayonet, therefore, meant the prevention of the dismemberment of China, which would have become imminent had the Muscovite been allowed to stay in Manchuria. Sagacious as they were, the mandarins apparently did not think it worth while to take this vital point into consideration, and deliberately taunted the Japanese, ignoring the understanding which they had put themselves on record as approving of. The railway project was in itself unjust enough, but when its ulterior aim is considered, it appears worse than unjust. But before entering into the evil designs 
concealed in the project, let us inquire whether Japan's contention on the question was warranted.

The contract for the construction of the Shinmintung-Fakumen Railway having become an accomplished fact, Japan was forced to abandon the hope of settling the matter in a friendly manner without recourse to diplomacy; it remained for her only to lodge with the Chinese government a formal protest against the execution of the contract. It was a delicate matter for Japan to handle, as one of the parties to the railway contract was a firm of the country with which she was in alliance. The firm freely utilized such British newspapers as were unkindly inclined towards Japan, and thus spread broadcast news of Japan's alleged violation of the " open door" principle. The exploitation of the British press by the promoters of the Shinmintung.Fakumen Railway proved so successful that the mistaken conception of the scheme soon overleaped the Atlantic and found expression in American newspapers. But amid warnings, alarms and protests voiced by misinformed British journals, Downing Street remained unmoved, fully recognizing the justifiability of the attitude Japan had assumed. Nor did the British government fail to detect the sinister motive ill-concealed in the apparently innocent project.

It is indeed difficult to see how the British government could have acted otherwise. The idea of inserting in a railway agreement with China an article forbidding the construction of competitive lines to a railway owned by a foreign nation is not new; it was not invented by Japan. On the contrary, Japan merely adopted a precedent established by other powers participating in railway enterprise in China. The Russo-Chinese convention 
of April 8, 1902, contains an article providing that in case an extension of the Shanghaikwan-Shinmintung line, or the construction of branch lines in Southern Manchuria is to be undertaken, the matter shall be previously arranged by an understanding between the St. Petersburg and Peking governments. Another instance of similar nature is found in the Russo-Chinese agreement of $\mathrm{I} 898$, relative to the construction of the Chengting-Taiyuan Railway. Article 5 of that agreement reads as follows :

"During the whole thirty years, or while the loan is unredeemed, the high authorities of Shansi shall interdict the construction of another railway or other mechanical means of transport between Cheng-ting and Tai-yuan, as such would be detrimental to the interest of this railway."

A third instance is furnished by the American-China Development Company, which on July I 3, I900, signed an agreement with the Chinese government, containing the following article:

"Without the express consent in writing of the director-general and the American company, no other rival railway detrimental to the business of same is to be permitted, and no parallel roads to the Canton-Hankow line are to be allowed to the injury of the latter's interest, within the area served by the Canton-Hankow main line or branch lines."

In the agreements of July, 1903, and of March, I907, both between China and the British and Chinese Corporation, Limited,- -one providing for the construction of the Shanghai-Nanking Railway, the other the CantonKowloon Railway-we find a similar provision: Lastly, Germany, in virtue of her Kiaochou agreements with China, claims the exclusive right of railway exploitation 
in the province of Shantung. If Germany, Russia, America, and Great Britain, which obtained their railway concessions without sacrificing anything and without giving China anything in recognition thereof-if these powers are justified in imposing upon China the restriction which we have noted, how much more justified must Japan be in claiming a similar privilege with regard to her Manchurian railways, after restoring to China the vast territory of Manchuria.

It remains for us to inquire whether the proposed Shinmintung-Fakumen line was of a nature to jeopardize the interest of the South Manchuria Railway. This question cannot be determined by merely considering the distance which separates the South Manchurian line from the proposed railway. More important than mere distance are topographical considerations. Thus a railway, entering a valley, undivided by any impassable streams and already occupied and actually served in all its parts by another line, would, if running parallel with and at a distance of thirty or forty miles from the original line and bidding for a share in its traffic, be clearly regarded as in the neighborhood of and detrimental to the established line. On the other hand, a railway separated from another by a mountain range could not be considered as in the neighborhood of such other line, even if within ten or fifteen miles of it. Now the distance between the main line of the South Manchuria system and the contemplated line is in many points considerably less than thirty five miles, and in few places more than that. Thus from Shin-min-tung to Mukden it is about thirty-two miles; from Fa-ku-men to Tieh-ling twenty-seven miles; and from Shin-tai-tsu on the South Manchuria line to the nearest point on the proposed line 
is only twenty-four miles. True, the Liao River traverses the region lying between the South Manchuria line and the proposed railway; but the stream forms no natural traffic boundary, as it is easily passable. As a matter of fact it is readily ascertained that the existing Japanese line serves the territory both to the right and to the left of the Liao. Produce in large quantities is conveyed from the Fa-ku-men regions to Tieh-ling in Chinese carts, and thence is carried southward by the South Manchuria Railway. Especially is this true in the winter season when the rivers are frozen over, and the whole country becomes one broad smooth highway. The logical conclusion of it all is that the ShinmintungFakumen line, if materialized, will draw away from the existing Japanese line no small portion of its traffic. Sir Alexander Hosie, acting commercial attache to the British Legation at Peking, writing recently on the commercial situation in Manchuria, said :

"It is true that the Imperial Railways of North China are competing successfully with the Japanese line from Newchwang to Mukden."

If this be true under the existing conditions, it cannot be doubted that with an extension of the Chinese line there would be at least a corresponding extension of competition.

Such was the nature of the Shinmintung-Fakumen Railway, and yet Japan's attitude was far from uncompromising. Thus in February, 1908, she proposed that she would indorse the project, if China would promise to extend the line to Tieh-ling or some other suitable point on the South Manchuria Railway. The Japanese compromise was suggested by the fear of probable extension of the Shinmintung-Fakumen line to the region farther 
north. The Chinese themselves seemed to attach greater importance to its eventual extension to Tsi-tsi-har or some other important point in Northern Manchuria, than to the Shinmintung-Fakumen line as such. Once such extension is realized, the South Manchuria Railway must entirely lose its raison d'être, and it was with the object of obviating the danger of such extension that Japan offered the compromise that she did. It was a reasonable proposal, and yet China, turning a deaf ear to it, forthwith proposed that the question be submitted to the tribunal at the Hague. Japan, of course, could not meekly accept China's new proposal, after having been slighted, defied, and taunted by the mandarins. So the matter came to a deadlock, and there it stood until China, towards the summer of 1909, virtually abandoned the scheme. By that time China had been given to understand that the British government could not favor a scheme which was calculated to run counter to the interest of its ally, even if the scheme was promoted by its own subjects. The British newspapers, too, had awakened to the real significance of the question, and had begun to doubt China's sincerity. Thus the London Times, which in the early stage of the controversy was inclined to support China, so signally modified its opinion towards the summer of 1909 as to publish the following editorial comment:

"Japan's right to veto the construction of a competitive line cannot be disputed either by China, who signed the protocol of December, 1909, or by Great Britain, to whom the protocol was communicated without her raising objections. . . . There is little doubt that one of China's objects in handling the Manchurian question has been and is to create friction between Japan and 
other powers. By giving to the British the contract of the Fa-ku-men Railway after having been informed that Japan would regard the scheme as a violation of the protocol of 1905, China doubtless hoped to embroil Great Britain with Japan. In this they were disappointed. The alliance and friendship with Japan are based too firmly on the interests of both countries to be seriously affected by such transparent manœuvres."

Nor was the Times the only British journal which discerned China's ulterior motive in putting forward the Shinmintung-Fakumen Railway scheme. Several other newspapers, notably the Globe and the Pall Mall, dealt with the question much in the same spirit as did the Times. Verily, the railway project was little more than a dummy behind which lurked a dastardly intrigue aimed at the estrangement of Japan and England. It was the old story-China tried to set ally against ally, and sow seed of dissension among powers, vainly fancying that the weakening of friendship among foreign nations would proportionately strengthen her own position. Such a perverted method of diplomacy cannot long be permitted to prevail, and it is time that China should learn to take diplomacy more seriously to heart. But China has not, and she is now trying to alienate American sympathy from Japan.

In June, 1907, the United States made a stupendous gift to China in the form of the relinquishment of her claim to the Boxer indemnity. This measure was taken undoubtedly with the object of winning back China's good-will, which the United States had lost through the outrages committed upon the Chinese on the Pacific Coast. About this time Japan's commercial strides in Manchuria aroused much anxiety and suspicion in 
America. The Chinese diplomats, with characteristic astuteness and sagacity, were not slow to read the signs of the times, and set their minds to make the most of them. By utilizing American distrust of Japan on the one hand, and on the other playing up to the American desire to befriend China, the mandarins fancied that the United States could be used to undermine Japanese influence in Manchuria. The apostle of this apparently shrewd diplomacy was Tang Shao-yi, the right-hand man of the then all-powerful Yuan Shi-kai. Tang Shao-yi also it was who conceived the ShinmintungFakumen Railway scheme which we have just described. Trained in modern jurisprudence and political science in one of the highest seats of learning in America, the Honorable Tang was nevertheless too closely allied with the traditions of his country to break with the perverted foreign policy of China. Seeing that his game in the Shinmintung-Fakumen Railway scheme was lost, he cast his eyes across the Pacific and set his mind to try his hand in America. Through his master Yuan Shi-kai, Tang succeed in persuading the Peking court to send him to America as special envoy to thank the Washington government for its magnanimity in waiving the Boxer indemnity. The envoy with a large suite arrived in Washington in the fall of 1908, when the Roosevelt administration was still in office. Apparently, the envoy's mission was innocent enough, but Tang Shao-yi had a scheme. Simultaneously with his arrival in America, the New York Herald abruptly began to advocate an American-Chinese alliance much of the same nature as the Anglo-Japanese alliance. It seemed to augur well for the Chinese diplomat. He must have passed many a happy night, dreaming of a union be- 
tween the greatest republic and the oldest empire on earth. But his dreams were not to come true. Like a thunderbolt out of the blue sky came the Root-Takahira notes of November, 1908, affirming Japan's friendship with America. That was a crushing blow to Tang's cherished ambition, but the worst was yet in store for him. Early in 1909, while Tang Shao-yi was still sojourning in America, the most startling news came from the Far East-Yuan Shi-kai had been deposed! With his master and patron at home stripped of authority, what could Tang Shao-yi do here in America? Nothing but leave the country with what dignity and grace he might, and hurry back to the hoary capital of China where a great political drama was then being enacted. Thus ended the American " mission" of Tang Shao-yi.

But Tang's efforts proved not entirely abortive. The Chinese government, whether adopting his idea or not, followed the policy of injecting American influence into the Manchurian situation. Meanwhile, Mr. Taft's succession to Mr. Roosevelt seemed not unfavorable to the realization of the Chinese scheme. Mr. Knox, whose intimacy with Wall Street is well known, was ready to back a group of money kings, who conceived the idea of investing on Chinese and Manchurian railways some of the dollars that were overflowing their pockets. So the pet scheme of China suited the new policy of America. The result was the launching of the Chinchou-Aigun Railway scheme, which I have fully described in the foregoing chapter. The Chinchou-Aigun Railway scheme is virtually the substitute for the Shinmintung-Fakumen Railway scheme; only the new project is divested of those features of the older one which 
were objected to by Japan. As I have stated, the Chinchou-Aigun line, if constructed, will deprive the South Manchuria Railway of much of its business, but inasmuch as the line will not run quite as near the Japanese line as the Shinmintung-Fakumen line was to run, Japan felt obliged to indorse the project, as she actually has. It would have served China's purpose more admirably had Japan provoked America's ill-feeling by joining hands with Russia in the effort to veto the scheme.

So much for the Shinmintung-Fakumen Railway scheme, and its offspring the Chinchou-Aigun Railway project. Now we must consider the Antung-Mukden Railway controversy which is equally illustrative of Chinese diplomacy. As has been observed, the AntungMukden line was a light military railway with a gauge of two feet six inches. To meet the exigencies of the war it was constructed hastily. To avoid the construction of tunnels and bridges, for instance, the line was given many wide détours and steep gradients, as well as many sharp curves. In consequence there was frequent danger of derailment. The hauling capacity of the engines was very small, three or four small passenger and freight cars constituting a maximum train. Where the grades were steep, even these short trains had to be divided into two or three separate hauls. All the way the trains ran at a dog trot, and as night traffic on such a line was impracticable, the transit between Antung and Mukden, though only I 88 miles distant, required two full days.

To obviate this inconvenience and danger, Japan, by the arrangement complementary to the Peking Treaty of December, 1905, obtained the right to improve the road so as to make it fit for commercial purposes. As soon as Japan was in a position to undertake the reconstruction 
of the line, she opened informal negotiations with China, hoping that the Peking court would be disposed to make necessary arrangements in a friendly manner and with no recourse to diplomatic tactics. In this, however, Japan was sorely disappointed, and the Tokio administration, in January, I909, formally proposed to China that commissioners be dispatched to survey the route. With the exception of a small section of some twenty miles between Mukden and Chen-siang-tun, the surveying work was completed in April, and the duly authorized Chinese commissioners expressed themselves perfectly satisfied with the result. Thereupon Japan proposed that construction be commenced in the already surveyed section, so that the line would be made available as speedily as possible as a connecting link between the Korean and South Manchurian systems in the great inter-continental line.

Instead of assenting to this reasonable proposal, China tried to prolong the pourparlers indefinitely on one excuse or another. Evading Japan's demand, she proposed that Japan should relinquish the right of policing the railway zone, and completely withdraw her railway guards along the line in question, ignoring that both these rights were conceded to Japan by the Peking Treaty of 1905. Worse still, the Chinese government on July 24th sent to Japan a most incomprehensible note, declaring that the work of improvement on the said line must be confined to the existing track, and that no broadening of the gauge would be permitted. Such a restriction, if concurred in, would have completely nullified the provision of the agreement of 1905 , as well as the result of the survey accepted by the Chinese commissioners. Japan, chagrined as she was, patiently and in a friendly manner 
tried to convince China of the unjustifiability of such proposals, and yet China maintained the same evasive attitude, until Japan's patience was exhausted. China's performance, from beginning to end, was characterized by apathy, insincerity, subterfuge, dilly-dallying, and utter disregard of treaty obligations. Certainly no nation can be expected to be more patient than Japan was. Japan was thoroughly justified in addressing to China the socalled "ultimatum" of August 6, 1909, declaring that she would proceed with the reconstruction work in spite of China's objection. It was no doubt a bitter pill for China to swallow, but in the life of a nation, as in the life of an individual, there are times when medicine is absolutely necessary. But did China swallow the medicine? No, she mistook it for poison, and submitting to her chronic weakness of trickery, she addressed to the powers a note, declaring that it was Japan, not China, which violated treaty obligations.

The Japanese coup, however, was not entirely without good effects upon Chino-Japanese relations. Even the callous mandarins were forced to ponder upon the signification of the incident, and to feel that they must take diplomacy more seriously. At any rate it materially assisted in bringing into speedy termination negotiations that had long been outstanding between China and Japan on various questions relating to Manchuria. The result was the conclusion of the two conventions of September 4, 1909. The first of these conventions is called the "Convention relating to Manchuria," and the second the "Convention relating to Chien-tao."

First as to the Manchurian convention. Article I of this document disposes of the long mooted question of the Shinmintung-Fakumen Railway. At last China 
definitely relinquished the right of constructing the said line without first consulting Japan. In the second place, the convention recognizes Japan's right to bring the terminus of the Tashichao-Newchwang branch of the South Manchuria Railway closer to the city of Newchwang than it is now located. This is a necessary sequel to the Peking treaty, which provides that China and Japan, "with a view to promote and facilitate intercourse and traffic, will conclude as soon as possible a separate convention for the regulation of connecting services between the railway line in South Manchuria and all the other railway lines in China." Thirdly, China confirms Japan's right to work the coal mines in the Fushun and Yentai districts, and agrees to exploit in conjunction with Japan such mines as may be found in other districts along the lines of the South Manchuria Railway. This, again, is nothing but the reassertion of a provision in the Peking treaty, wherein China consented "to all transfers and assignments made by Russia to Japan," and wherein Japan agreed to conform, "in the matter of railway construction and exploitation," "to the original agreements between China and Russia" ; and Russia in connection with her railway concession in Manchuria enjoyed the privilege of exploiting mineral resources within the railway zones. It must not be understood that this creates a mining monopoly for China and Japan along the South Manchuria Railway lines. As the provision was couched in terms whose exact meaning was not quite clear, the United States inquired of the Chinese and Japanese governments whether the high contracting parties meant to reserve mines along the South Manchuria Railway lines exclusively to themselves; to which China and Japan replied that such was not the intention. 
From the above statement it will be seen that the Manchurian convention gives Japan no fresh privileges, as was universally presumed by the American press at the time of its conclusion. On the other hand, Japan by the same instrument made an important concession in favor of China in that she agreed to pay to the latter a certain amount of tax upon the output of the Fushun and Yentai coal mines.

The "Convention relating to Chien-tao," as the title indicates, deals with the long-disputed district of Chientao. This territory which lies, roughly speaking, between the River Tumen, which empties into the Japan Sea, and the Chang-pai Mountains, is divided into two parts, Eastern and Western; and it is Eastern Chien-tao, with an area of some I,550 square miles, which was disputed by Japan in behalf of Korea. Owing to the fact that the overwhelming majority of its population were Koreans, the territory seems to have been claimed both by China and by Korea for many years before Japan established a protectorate over the peninsula. At the latest computation there were in the country some 83,000 Koreans as against only 27,000 Chinese. When the Japanese authorities undertook to protect this Korean population, they found somewhere at the foot of the Chang-pai range a stone tablet, the inscription on which clearly showed that it was planted on May I5, I7 I2, during the reign of the first emperor of the present Chinese dynasty, in order to fix the boundary between Korea and Manchuria. The inscription stated that the representatives of the two countries agreed that the River Tumen on the east and the River Yalu on the west be made the line of delimitation between the Korean and Chinese territories. Now, there are in that region two rivers whose names, though 
written in different Chinese characters, are both pronounced "Tumen." One Tumen is a tributary of the great Sungari River, the other Tumen empties into the Japan Sea. That the river named in the inscription was the Sungari branch was evident from the characters used, and in the absence of further evidence, and upon the strength of various data favorable to Korea, Japan presumed that the territory known as Eastern Chien-tao rightfully belonged to Korea.

In the later stage of the negotiation, however, China seems to have produced new evidence purporting to nullify the above-mentioned delimitation. This evidence was not quite convincing to Japan; but, anxious to maintain amicable relationship with China, the Mikado's empire renounced her claim, and recognized Chinese sovereignty in the territory. In consideration of this concession, China agreed to extend the Kirin-Changchun Railway to the Korean town of Hoi-ryong, and to borrow from Japan one-half of the fund required for this work. The important nature of this railway has been fully described in a previous chapter. Japan also persuaded China, in the convention under review, to open four towns and villages in Chien-tao to international trade and residence, which will prove a material contribution to the "open door."

A casual observer may find in this Chien-tao convention an objectionable feature in that it authorizes the Japanese consular official to attend the Chinese court in the hearing of either civil or criminal cases relating to Korean subjects residing in Chien-tao, and requires the Chinese authorities to previously notify the Japanese consul where cases affect the lives of Korean subjects. As a matter of fact, this privilege conceded to the Japa- 
nese is a very mild form of what is commonly called exterritoriality. It has been the custom of all civilized nations to maintain exterritoriality in a country whose administrative and judicial system is not up to their own standards. In virtue of that usage people from advanced countries residing in a backward country are above the native law, but subject to the jurisdiction of their own consular courts. In China it was the British who first exacted the grant of a concession in the open ports, within which their consuls should have chief, if not exclusive, authority not only over the British subjects but also over the Chinese population. Other nations soon obtained the same privilege. Even where no special quarter was thus marked out as a "settlement," the foreign subject was exempt from control by the local Chinese authorities, but was controlled by his own consul.

Japan might have demanded the right of exterritoriality for the Korean subjects in Chien-tao, for Korea under Japanese rule had already adopted an efficient modern system of law courts. But considering peculiar circumstances existing in Chien-tao, she recognized the jurisdiction of the Chinese court over Koreans, reserving only the right to protest against such decisions as she might believe to be rendered in disregard of law. Even this moderate concession must be distasteful to the Chinese government, but it is inevitable so long as China remains in its present unstable state. She is still on probation, and the only way to recover the exercise of her sovereign rights is to show herself worthy of confidence, not by indiscreet anti-foreign agitation, but by the thoroughgoing renovation of her internal conditions. China ought to learn a lesson from the experience of her little neighbor Japan. The Sunrise Empire had her period of pro- 
bation, when exterritoriality fixed upon her the stigma of inferiority; but when she had proved her right to a place in the comity of nations, with good laws administered, foreign powers were forced to allow her the exercise of all the prerogatives of sovereignty. By pursuing the course followed by Japan, and by abandoning her petty diplomacy of sowing dissension among powers, and by this alone, can China hope to put an end to the imperium in imperio, which the powers have set up within her borders in the form of "settlements," consular courts, the policing of railway zones, and the like. As a Chinese proverb has it, "Heaven helps no one who does not help himself." It is a law stern and merciless, but there is no escape from it, so long as we live in this hard world of ours. 
RUSSO-JAPANESE RELATIONS IN MANCHURIA

HE recent attitude of Japan towards Russia

has been a subject of much severe criticism in

1. America, and it seems proper that the real status of Russo-Japanese relations with regard to the Manchurian question should be laid clear before the Americans. The most widely quoted of such criticisms is, I believe, Mr. Jacob H. Schiff's address made before the Republican Club of New York City in February last. As reported by newspapers, the speech was a downright prediction of an American-Japanese war over the Manchurian question; but it may not be fair to judge his views from miscellaneous versions of his address that found their way to the columns of newspapers. Let us hear Mr. Schiff himself explain, in a letter to the Japan Advertiser, an American daily in Yokohama, what he really did say:

"It can certainly not give any satisfaction to the American people, when they find Japan, to whom they had lent their undeserved support in her desperate struggle for self-preservation hardly more than a decade ago, joining hands, under the protection of England, with her erstwhile foe who sought to crush her, and thus combine against the forces of civilization, who wish to see established a strong, self-reliant China, rather than an important vassal state, a second India. America will be the last to deny Japan's dearly purchased right to work out 
its manifest destiny on the Asiatic continent, but Japan must not seek to do this by acting in unison with Russia, whose methods of government are not such that its blessings ought to be permitted to be extended beyond its own borders."

There is, I concede, some truth in Mr. Schiff's assertion, but it is the kind of truth that does not bear close scrutiny. Certainly Mr. Schiff cannot expect Japan to keep on fighting, or even antagonizing Russia indefinitely simply because the Russian method of diplomacy or system of government is not, judged by the standards of other civilized countries, what it ought to be. We did not fight Russia much in the same spirit as a Christian missionary would fight a heathen religion. To protect our legitimate interests both in Korea and in Manchuria, and to safeguard our existence, to which Russian descent upon those countries was certain to spell a menace-that was the only reason we had to measure swords with the Muscovites. Russia's method of dealing with the Jewish race, her persecution of political convicts, her dreadful exile system in frozen Siberia, her traditional policy of keeping her peasants ignorant and downtrodden, her absolute system of government which is wrapped in a cloak of constitutionalism too thin to conceal the real figure under it-all these and more the Japanese do not care to emulate any more than Mr. Schiff does. But that was not the reason why we ventured upon a mighty conflict upon the issue of which seemed to hang our existence.

We extremely disliked the Russian method of diplomacy before the war. Then subterfuge and insincerity characterized her attitude towards us. This was because the Muscovites underestimated our prowess, military and 
otherwise, and failed to realize how firm our determination was. To them, Japan was a nation of "yellow monkeys," which need not be taken seriously in diplomatic dealings. So they toyed with us, defied us, affronted us, and finally ignored us. But the war taught Russia that the Japanese were a nation not to be trifled with, and with the dawn of this new sentiment upon her the chicanery and subterfuge with which she had dealt with the Japanese were abandoned. Russia having thus learned to treat with us with due respect and circumspection, the way was readily prepared for us to come to a clear understanding with her, in order that our interests in Manchuria might be safeguarded and promoted, in so far as such interests would not encroach upon the sovereign rights of China. It would be the height of folly for Japan to cherish animosity towards her former foe, when the latter showed a willingness to become her friend. She desires peace above anything else, so that she may extend her foreign trade, develop her resources, and lighten the heavy load of taxes which the war laid upon her subjects. Most of all Japan needs Russia's coöperation in order to turn her Manchurian railways into a financial success. Russia tried, for some time after the war, to cripple our railway enterprise by refusing to establish any traffic connection between the Eastern Chinese and the South Manchuria Railway. Without securing this connection the South Manchuria system cannot expect to have any share in the inter-continental traffic between Europe and the Far East. How is Japan to attain this end without befriending Russia? She has borrowed of England $\$ 20,000,000$ for her railway enterprise in Manchuria. How is she to pay this debt, if she does not take advantage of every opportunity that can 
be utilized without infringing upon the rights and privileges of other nations? When we think of this, we feel we must not be too fastidious in dealing with our neighbor, whose business coöperation we are obliged to seek. Our neighbor may not lead the life we would have him lead, nor may he manage his own affairs in a manner we can approve of ; but that is a matter which we feel constrained to refrain from interfering with, when we are forced to bend all our energies to putting our own venture upon a paying basis, so that our sons and daughters may not be hampered by the legacy of debts that we have contracted. Apparently these considerations did not enter Mr. Schiff's mind, or he certainly would have been more lenient in criticizing Japan's attitude towards Russia.

The first step towards a Russo-Japanese rapprochement was taken two years after the war, when a convention was concluded between the two powers, binding each of the high contracting parties (I) "To respect the actual territorial integrity of the other, and all the rights accruing to one and the other party from treaties, conventions and contracts in force between them and China," (2) "To recognize the independence and the territorial integrity of China and the principle of equal opportunity in whatever concerns the commerce and industry of all nations in that empire," and (3) "To sustain and defend the maintenance of the status quo and respect for this principle by all pacific means within their reach." Such was the substance of the convention signed on July 30, 1907. Almost simultaneously a convention arranging for the connection of the Russian and Japanese railways in Manchuria, a treaty of commerce and navigation, as well as a fisheries convention, were entered into between the 
two nations. There was nothing unusual in the treaty of commerce and navigation, while the railway convention was of a temporary nature to be applied pending the formation of a more satisfactory arrangement. But in the fisheries convention Russia made important concessions in favor of Japan. It bestowed upon Japanese subjects the right to fish along the entire Russian coast, with the exception of inlets and rivers, on the Behring Straits and the Okhotsk and Japan Seas. This privilege applied not only to fish but all sea animals other than sea otters. While the Japanese thus engaged in fishing were required to pay to the Russian authorities the same taxes as Russians, the export of fish to Japan was declared to be free from all export duty.

The convention of July 30, 1907, the substance of which we have noted, placed Japan and Russia in a relation of entente cordiale. And yet the Russians in general were far from understanding Japan's true motives and intentions. A group of Russian officers, headed by General Linevitch, still entertained the notion that Japan, feigning a desire for peace, was preparing for another war with Russia. To make the situation still worse, not a few writers published books and articles in various languages, declaring that the peace treaty of Portsmouth was but an arrangement for a truce. Russian newspapers such as the Retch, the Russkoe Slovo, the Golos and the Bourse Gazette sounded ever and anon alarmist notes, as if Japan were on the point of seizing the Russian outposts in the Far East. It was at this time that Mr. Schipoff, Russian Minister of Finance, visited Japan to see for himself what that spasmodic alarm all meant. Japan, of course, did not let this God-sent opportunity slip without making the utmost efforts to con- 
vince the Russian statesman of her sincere intention of being at peace with all the world. Mr. Schipoff's visit to Japan was soon reciprocated by a visit to St. Petersburg of Baron Goto, who then, as governor of the South Manchuria Railway, was directly responsible for the success or failure of Japanese enterprise in Manchuria. While his chief mission in St. Petersburg was to negotiate for harmonious traffic relations between the Eastern Chinese Railway and the South Manchuria system, it was generally believed that he availed himself of the occasion to impress the Russian statesman with Japan's earnest desire to befriend Russia. Baron Goto was most cordially received in the official circles of St. Petersburg, and thus another step towards a RussoJapanese rapprochement was taken.

Notwithstanding all these official efforts on both sides, Russian newspapers did not cease to publish sensational rumors as to Japan's belligerent attitude towards Russia. It may have been that these newspapers were influenced by bourse manipulators, or it may have been that they merely intended to regale sensation-seekers. At any rate, news and comments in these papers with regard to the Far-Eastern situation had, by the end of 1909, become so harmful that the Russian authorities felt obliged to issue a statement, categorically denying the authenticity of warlike reports published in the press. So clearly does this communique explain the attitude of the Russian government towards Japan at that time that its reproduction here may be justified :

"There has latterly been evident in the press a particularly nervous feeling created by rumors of a conflict which is alleged to be impending between Russia and Japan. Disquieting reports from the Far East fill the 
newspapers, and this feeling is penetrating in a regrettable manner to wider circles. According to present reports, the effect of these rumors is making itself especially strongly felt in our frontier territory in the Far East, where, under the influence of a conviction of the inevitableness of an approaching war with Japan, which is becoming deeply rooted in the minds of the community even among representatives of the administration, the feeling of anxiety is assuming such a strained character that it reacts directly upon private enterprise, obliging business men to apply to government organs for information as to how far the rumors current are correct, and whether commercial and industrial undertakings in the Far East may rely upon the preservation of peace. The interests of the people forbid the government to abstain from intervention in this disturbing state of affairs, and oblige it to declare categorically that all rumors of complications between Russia and Japan at the present time are absolutely unfounded. The government has made use of the four years that have elapsed since the last war to conclude a whole series of international agreements, designed to wipe out all traces of enmity left behind by the war and to assist in the peaceful development of the political and economic relations of the two countries. From this point of view, next to the commercial treaty and the fisheries convention, particular importance attaches to the political agreement of 1907 , concluded with the object of mutually guaranteeing the integrity of the territorial possessions and treaty rights of the two powers in the Far East. These acts undoubtedly contribute to the stability of the general political situation on the coasts of the Pacific, and particularly to Russo-Japanese relations, which completely lack the 
character wherewith certain newspapers endeavor to invest them. As regards these relations, there has been no friction of any kind since the treaty of 1907, nor have any misunderstandings arisen. Communications which have reached the Minister of Foreign Affairs direct, as also the impressions which the Minister of Finance gained during his recent journey in the Far East, contain nothing disquieting. On the contrary, they emphatically confirm that in our relations with Japan complete mutual good-will is to be perceived and a readiness to settle in peaceful friendly manner all questions which may arise."

With Russia's position made so clear, it became all the easier for the two countries to enter into an entente cordiale, divested of all suspicion and misgiving. Meanwhile, Chinese diplomacy in Manchuria was such as would virtually assist in cementing Russo-Japanese friendship. As I have said in previous chapters, it had been Japan's earnest desire to establish a close friendship with the Chinese, and extend to them hearty cooperation in their efforts for internal rehabilitation. This hope was utterly blighted by the apathetic, unappreciative attitude which China consistently assumed towards Japan. Not only this, but China, by dint of her characteristic diplomacy, conspired to alienate British sympathy from us, and thus cast a shadow over the Anglo-Japanese alliance.

To convince the Chinese of the folly of attempting to undermine the Japanese position in Manchuria by trickery and conspiracy, the Mikado's Empire felt it advisable to join hands with Russia, thus forming a sort of triple alliance between Great Britain, Russia and Japan. It appeared obvious that without such a power- 
ful union China would never learn to take Japan and her legitimately acquired rights seriously, and deal with the latter nation with sincerity and respect.

Simultaneously Secretary Knox's Manchurian policy was such as would invite Japan to turn her face towards Russia. It would be rash to conclude that the Knox diplomacy was the direct cause of the Russo-Japanese rapprochement; indeed, the majority of the Japanese press stoutly decline to accept any such views as would attribute the conclusion of the recent convention between St. Petersburg and Tokio to Secretary Knox's proposal for the neutralization of the Manchurian railways and his Far-Eastern policy in general. And yet no keen observer can fail to see that American attitude towards the Manchurian situation was, at all events, one of the causes which precipitated the formation of the entente, if it did not actually drive Japan and Russia into each other's arms. I have already made it clear that the necessity of establishing a friendly relationship between Russia and Japan had been felt long before America's Far-Eastern policy assumed such serious aspect as it now does, and it was certain that an entente cordiale would be entered into between the former belligerents without any foreign influence impelling them to that goal. With the Knox scheme for the neutralization of the Manchurian railways, the launching of the Chinchou-Aigun Railway project, the rumor of a probable American protest against a certain phase of the Chino-Japanese convention of August, 1909, Russia and Japan felt more forcibly than ever the advisability of arriving at a perfect understanding with each other. The psychological moment had come, and the two powers promptly seized it. The result was the convention of July 4, I910, reasserting the principles es- 
tablished by the convention of July 30, 1907, which we have already noted. Let the convention itself explain its nature and object :

"With the object of facilitating communications and developing the commerce of nations, the high contracting parties mutually engage to lend to each other their friendly coöperation with a view to the amelioration of their respective railway lines in Manchuria and the inprovement of the connecting service of the said railways, and to abstain from all competition prejudicial to the realization of this object.

" Each of the high contracting parties engages to maintain and respect the status quo in Manchuria resulting from the treaties, conventions and other arrangements, concluded up to this day, between Japan and Russia, or between either of these two powers and China. Copies of aforesaid arrangements have been exchanged between Japan and Russia.

"In case any event arises of a nature to menace the status quo above mentioned, the two high contracting parties shall, in each case, enter into communication with each other in order to arrive at an understanding as to the measures they may judge necessary to take for the maintenance of the said status quo."

It has been observed that the establishment of a perfect coöperation between the Eastern Chinese Railway and the South Manchuria system was one of the main considerations which persuaded Japan of the advisability of entering into a cordial relationship with Russia. That this observation is correct is indicated by the fact that the provision for the connecting service of the railways is placed in the foreground of the new convention. In spite of the railway agreement of May, 1907, to which 
reference has been made, Russia was naturally reluctant to make satisfactory arrangements, and there remained much to be done for the improvement of traffic relations between the Russian and Japanese railways in Manchuria. Soon after the conclusion of the new convention, the respective representatives of the South Manchuria Railway and the Eastern Chinese Railway met at St. Petersburg with a view to making the desired arrangement. Thus the mooted question was at last solved in a manner satisfactory to both parties.

The second and last articles of the convention are virtually the reiteration of the principles embodied in the Anglo-Japanese treaty of alliance of 1905, the FrancoJapanese convention of June, 1907, the Russo-Japanese convention of July, 1907, and the diplomatic notes exchanged between Japan and America in November, 1908. They emphasize the necessity of maintaining the status quo in Manchuria, having for its corollary the preservation of the peace in the Far East in general. In seeking to attain this end the contracting powers pledge themselves to observe not only the treaties and agreements between themselves, but those concluded between either of them and China. This implies that the principle of the "open door" and equal opportunity shall be respected, and that the Manchurian railways, with all other enterprises of Japan and Russia, shall be handed over to China at the expiration of the periods prescribed in treaties and conventions. But China deemed the conclusion of the Russo-Japanese pact an occasion fit to remind them of their obligation to withdraw from Manchuria at the fixed time, and in indorsing the convention by an official communique addressed to the powers, she took particular pains to emphasize that 
point. The authentic version of this communique is as follows :

"The government of China recognizes that the newly concluded convention between Russia and Japan consolidates the principles defined in the conventions and agreements between either of the contracting parties and China, as it is declared in the convention that all the conventions and agreements between China and Russia, those between China and Japan, and those between Russia and Japan shall be acknowledged and respected. It may be noticed that Article 3 of the Portsmouth Treaty provides that Russia and Japan mutually bind themselves to hand over Manchuria to China to be absolutely restored to her administration, and that territorial interests or preferential and monopolistic concessions, which are calculated to injure the sovereignty of China and to be against the principle of equal opportunity, shall not be allowed in Manchuria. In Article 4, Russia and Japan engage each other not to prevent China from taking measures common to all the powers with a view to developing the commerce and industry of Manchuria. In the same year, China and Japan concluded an agreement with regard to affairs in the Three Eastern Provinces, according to the Portsmouth Treaty. By this step, the open door in Manchuria became a fait accompli. Acting upon the principles of the Portsmouth Treaty, therefore, and carrying out the stipulations defined in the conventions and agreements with Japan, China will endeavor to observe the principle of equal opportunity and to develop the commerce and industry of the Three Eastern Provinces."

It has been repeatedly asserted by Western critics that the Japanese method in Manchuria is exactly the method pursued by Russia before the war. Some writers have 
even gone so far as to say that Russia was more generous to foreigners and foreign interests than Japan is. Such assertions can be made only by ignoring patent facts or with the evil purpose of misguiding the public. At any rate it is no difficult task to prove that the Japanese method of to-day is radically different from that of Russia prior to the war. Let me elucidate this point.

It was the policy of Russia to exclude foreigners from its newly acquired territories or its spheres of influence in the Far East, so that its military operations might be kept concealed from the world. By the treaty of Aigun, she obtained the exclusive right to navigate the Amur, the Sungari, and the Ussuri, forbidding the vessels of any other country, excepting China, to utilize these waterways. At Vladivostok it was the rule not to permit more than two foreign vessels to enter the harbor at a time. On April 18, I903, the Czar demanded of the Peking court to agree not to open any new treaty ports in Manchuria, or permit new consuls without previous consent of St. Petersburg, or employ any foreigners, except Russians, in any administrative capacity in said country as well as Mongolia. Has Japan ever put forward such a demand as this? Again, in August, Igor, the Imperial Russian Controller of Newchwang issued the following proclamation, which was in direct contravention of the rights of a treaty port:

"As this port has now reverted to the control of the Imperial Russian government, all you who have matters in dispute and the like should bring your petition to the superintendents or other government officers, where redress can be obtained and cases settled in perfect justice and impartiality. . . . If after the issuance of these presents there be found any person disobeying this proc- 
lamation, I will punish the delinquent severely and will exercise no mercy. Tremble! Be most careful! Do not say by and by that you have had no notice."

Has Japan ever been so audacious as to assume so overbearing an attitude towards foreigners in Manchuria? The collection of maritime revenues at Newchwang was carried on by Russo-Chinese officials, who wore Russian uniform, and therefore appeared to the natives to be actually the emperor of Russia's officials. Has Japan ever usurped any customs establishment in Manchuria in utter disregard of Chinese sovereignty? The London Times of September I3, I90I, stated that the Russian administration at Dalny had refused to permit Americans to build warehouses for the storage of American kerosene, and had also announced the intention of excluding American oil altogether from Manchuria. Has Japan ever adopted such a flagrant measure of discrimination against American trade? During that period the Russian authorities looked upon Americans " with keen suspicion, if they ventured further than a couple of miles from Newchwang," the Russians refused " to recognize a British passport in Manchuria and insisted that all British subjects travelling in that country must possess Russian passes, which were procured from Port Arthur only with great difficulty and considerable delay." Has Japan ever put such obstacles, except during the war, in the path of foreign travellers in Manchuria?

Now that Japan and Russia are bound by ties of close friendship, it is a delicate task for us to tell the truth about the Russian method in the historic days of Viceroy Alexeieff, knowing that the truth is cruel. Yet Russia will, I trust, be magnanimous enough to admit the blunders and mismanagement attending her military misad- 
venture in Manchuria, which was directed by the Czar's military entourages in defiance of sane counsels of broad statesmanship. Russia has repented, and with the repentance has come a marked modification of her policy in the Far East. Let us, then, be lenient towards her, and be friends with her, in the name of universal peace and fraternity! 


\section{VI}

JAPAN'S COMMERCIAL ADVANCE IN MANCHURIA AND THE “OPEN DOOR"

T $\mathrm{N}$ May, I906, the Mikado summoned before the throne all his ministers, as well as the "elder Ltatesmen," and commanded them to express their views frankly and freely as to what policy Japan should adopt in Manchuria. After a deliberation, which lasted several days, this council reached the decision that China's sovereignty should be respected, and that the principle of equal opportunity for all nations should be adhered to with the utmost sincerity. In spite of all the harsh judgments passed by foreign critics, I do not hesitate to assert that Japan has been faithful to this fundamental policy sanctioned by the throne. If the "open door" must be so interpreted as to bind Japan not to promote her own interests, in order to give opportunity to other nations, she has deviated from that principle. On the other hand, if it implies that all nations, Japan included, are equally entitled to exploit the markets and resources of Manchuria by all legitimate means, then her activities in the Three Eastern Provinces have assuredly been unimpeachable. Having preferred the latter view-for what else could she do?-Japan has subsidized her steamship lines to Manchuria, installed commercial museums in vàrious important Manchurian towns in order to advertise her merchandise, sent commercial agents to inquire into the Manchurian markets, and, what is more impor- 
tant, has become a most liberal purchaser of Manchurian products, thus establishing close business relations with the native producers and merchants. These, reënforced by the advantage which she enjoys over Western nations in geographical position and in the cost of production and transportation, have enabled her to push her trade in Manchuria with remarkable success.

What is the secret of Japan's commercial success in Manchuria? This question Westerners usually answer with the hackneyed two words-cheap labor. Japan has an abundant supply of cheap labor, which enables her to turn out merchandise at comparatively small cost : hence she is able to undersell her Western competitors-such is their simple reasoning. But there is a less charitable view, which attributes Japanese success wholly to the underhand measures of discrimination and double dealing. The first view tells only half truth, the second is a slander, pure and simple. As I see it, the first cause of Japan's commercial success in Manchuria lies in the fact that Japan, of all foreign nations, has been the only customer for Manchurian products-a fact which has enabled Japanese merchants to enter into more intimate and lasting business relations with the native traders and consumers than is otherwise possible. Japan, buying so much from Manchuria, must needs send to that country in exchange her manufactured articles. That this is perfectly natural no one can gainsay, yet, in my knowledge, it has never been, except in one case, pointed out clearly enough to bring it home to the Western people interested in Manchurian trade. That solitary exception is found in an article by George Bronson Rea, appearing in a recent issue of the Far Eastern Review (Shanghai, China) published by that gentleman. So important is 
this article that I may be permitted to extract from it at length.

The real basis of Japan's success in Manchuria is, Mr. Rea believes, the operation of the fundamental economic law, that the country consuming the major portion of the exports of another country holds the most advantageous position in supplying its necessary imports. Now Japan has for years been the chief consumer of Manchuria's principal export, consisting of beans and bean-cake. Before the Russo-Japanese war the Chinese trader brought the bean product to the market at Newchwang, and received in exchange foreign piece goods and sundries. The Japanese purchasers of beans and beancake paid the foreigner his profit on the turnover, plus the storage charges, lighterages, and freight, and were apparently contented with a situation impossible for them to remedy. Then came the war and all was changed. Japan began an aggressive campaign to gain control of the Manchurian trade, and success soon crowned her efforts. Says Mr. Rea :

"Under these conditions the foreign merchants and their agents in the interior were placed at a disadvantage from the outset. As they could not penetrate into the interior and purchase beans by an exchange of commodities, they were reduced to selling their wares for cash-the one thing the native was short on. If they attempted to follow the lead of the Japanese and barter merchandise for beans, they were handicapped by their various charges at Newchwang, and having to ultimately sell to the Japanese at their price, which of course was unprofitable under the then existing conditions. The decadence of American and European imports followed as a natural consequence. A few venturesome American 
and British piece goods agents established themselves in the interior, firmly determined to win back their lost trade, but acting solely as sellers and unable to reciprocate by purchasing the products of the farmers, results were discouraging, and they finally had to abandon the field as unprofitable. This, in short, is the real reason for Japan's success in Manchuria."

Not a few critics have been at pains to create in Europe and America the impression that Japan discriminates against foreigners in Manchuria in shipping and railway rates. The subsidized shipping of Japan, one of such critics insinuates, carries Japanese goods at a minimum charge, subject to further rebates as quantities rise, from the place of manufacture to the port of Tairen, thence the goods are carried at special rates to their selling place over the trucks of the South Manchuria Railway. In Mr. Rea's opinion, such charges and insinuations fall far short of the mark in explaining the loss of the Manchurian market for American and European products, and he sums up the whole situation in these words :

"It is a far cry from high diplomacy to the humble soya beans, yet we hold to the belief that the past and present commercial situation and ultimate solution of the vexatious Manchurian question is bound up in the control of this one product."

That really furnishes the key to the Manchurian question. Here is a country where there is no manufacturing industry, and whose agricultural products can be enumerated upon five fingers. Beans and their byproducts, bean-cake and bean-oil, constitute its only important produce. What can Western nations do with them? The annual crop of beans is approximately 
$\mathrm{I}, 000,000$ tons, which has a value of $\$ 25,000,000$. How is Manchuria to dispose of this enormous quantity? The Manchurians themselves do not want them, for their staple food, as well as their animal feed, is millet. Europe and America do not know, or at all events have not known, how to utilize them. Japan and China are the only places where the goods can be sold.

Prior to the Chino-Japanese war, beans and bean-cake were almost exclusively distributed through the ports of Swatow, Amoy and Canton, among the southern provinces of China, where mills were erected for extracting the oil from the beans, and where the bean-cake was used for fertilizing the sugar plantations. Then came the Chino-Japanese war, and the Japanese, having, during their occupation of the Liao-tung Peninsula, realized the value of the Manchurian produce, became its most liberal purchaser. So rapidly had Japanese purchases of the pulse and bean-cake multiplied that by 1899 they exceeded the total export to Southern China. The Japanese knew how to utilize beans and bean-cake. The white, red, and small green beans-for there are six varieties of beans-they manufactured into various food stuffs; from the yellow, black and large green beans they made bean-cake and bean-oil. The bean-cake they used as fertilizer and animal feed, and the bean-oil for culinary and other purposes. They found out that Manchurian beans could be laid down in Japan at less than it cost to produce the same varieties in their own country. Why not buy them from Manchuria rather than raise them at home?

The Russo-Japanese war proved, as we have noted, a golden opportunity for Japanese traders to establish direct business relations with the native producers of 
beans or native dealers in the commodity, thus doing away with the medium of foreign merchants in Newchwang. Since the war Japanese purchases of beans increased by leaps and bounds, until to-day almost ninetenths of the Manchurian produce is purchased by the Japanese. Here lies the secret of the success which Japan's export trade has secured in Manchuria. Here also is where all the indiscriminate talk about the closing of the "open door" came in. Let American traders go into the interior of Manchuria and buy beans and beancake and bean-oil, just as the Japanese are doing, and they may rest assured that their export trade to Manchuria will increase proportionately, just as Japan's has. Unless they could do that, all the hysterical condemnation which some American critics are capable of piling upon the Japanese would accomplish nothing but make them ridiculous and contemptible in the eyes of the intelligent and the thoughtful. "Of all broken reeds," warns Mr. Roosevelt, "sentimentality is the most broken reed you can lean on." It is nothing but sentimentality which tempts some critics to indulge in effeminate complaints about the "open door" in Manchuria.

But I must come back to the bean question. It is doubtful whether the Japanese will be able to maintain their supremacy in the bean trade of Manchuria. The firm of Mitsui, which has had the control of Manchurian beans, thought it an excellent idea to teach Europe how to utilize the Manchurian produce and thus extend its profitable business abroad. The enterprise is likely to result in an unexpected situation. It has proved successful in so far as it made the Westerners appreciate the value of the bean, but it has opened wide, to Japan's own disadvantage, the very door which foreigners claimed 
was being closed against them. The British oil-seed crushers pronounced the Manchurian bean as the next best oil producer to cotton seed. The immense possibilities of the bean trade soon attracted the attention of British traders, several of whom entered the arena, with the intention of buying beans direct from Manchurian farmers, and not through the Japanese firm of Mitsui. Naturally British oil-seed crushers will favor the purchase of beans through British exporters. Should the British traders succeed in this novel undertaking-and there is no reason why they should not-they will likewise succeed in selling wares of their own country in exchange. At any rate the time seems not far away when the export trade of Manchuria will no longer be monopolized by the Japanese alone. Then the tables will be turned; and just as Japanese trade in Manchuria increased in proportion as her purchase of Manchurian goods increased, so will any Western nation, which becomes a good customer for beans and bean-cake, succeed in making incursion into the field where Japan is now established. And the Western world may rest assured that when that time comes the Japanese will not heap upon their successful rivals groundless charges and vile epithets, but will face with manliness and dignity the new situation which is the inevitable result of the natural laws of trade.

Here we may pause a moment and examine a few statistics to learn something of the real extent of Japanese patronage of Manchurian products. As the reports of the Chinese Customs do not, except in a few cases, record the destination of goods exported, it is difficult to ascertain the exact amount of Japanese purchases in Manchuria. But those few cases, where such distinction 
is shown, seem sufficient to indicate how important a factor Japan is in the export trade of Manchuria. In I 907 exports through the port of Newchwang, " ninety per cent. of which were made up of beans and beancake," amounted to 7,685,359 taels (a tael is about seventy-nine cents), of which " ninety-five per cent. was for Japan." In I908 the same port exported 4,583,000 piculs (a picul is $133 \mathrm{I} / 3$ pounds avoirdupois) of bean-cake, of which "all but an infinitesimally small portion went to Japan." The Maritime Customs at Antung reports that in 1907 "the steamer-borne beans and bean-cake went almost exclusively to Japan"; in 1908 the same port exported beans, silk, timber, and other products to the extent of 709,953 taels, of which 691,000 taels was for Japan. Turning to the port of Tairen we learn that exports through that port during the first six months of 1907 amounted to $3,735,288$ taels, practically all of which was for Japan; exports during the latter half-year totalled $2,205,677$ taels, Japan sharing in it to the extent of $2,128,786$ taels. In 1908 beans exported through Tairen amounted to $2,709,668$ piculs, of which $1,398,605$ piculs went to Japan.

Turning to Japanese source of information, we find in the Japan Year Book for I9lo that in 1908 beans and bean-cake were imported to Japan to the extent of $6,659,000$ yen and 23,61 7,000 yen, respectively. In 1909 Japanese purchase of beans amounted to 6,260,000 yen, and that of bean-cake to $24,189,000$ yen. It may be noted that these figures include imports both from China proper and from Manchuria, but it is safe to say that practically all the beans and bean-cake imported to Japan in those two years came from Manchuria, for China proper has never produced beans to such an extent as to 
make their exportation possible. At any rate it is certain that Japanese purchase of Manchurian beans and beancake is not less than 30,000,000 yen per annum. But beans and bean-cake are not the only commodities Japan buys of the Three Eastern Provinces. Let us see what else she purchases.

Next to beans wild raw silk and cocoons are the most important products of Manchuria. The raw silk finds its way largely to Japan and Shanghai, while the cocoons are shipped mostly to Chefoo, where they go on the market to feed the local Chinese filatures and the German one at Tsing-tau. That Japanese demand for the raw silk and cocoons will steadily increase is assured by the establishment of a Japanese filature, turning from its 200 machines at least a picul per day for the Osaka looms, as well as by two Japanese inventions which should bring tussore upon the market as a competitor with the domestic silks of China and Japan. The first of these inventions is a new process for bleaching the silk, which will render it amenable to dyes of the lighter shades; the second is a spinning machine, which makes a smoother and more uniform thread than is now producible. Facts such as these are usually unnoticed in Europe and America, but they are just what assists the Japanese in pushing their trade in Manchuria.

Aside from the fact that Japan is the most liberal purchaser of Manchurian products, there are various factors which facilitate her commercial advance in Manchuria. In the first place, Japanese canvassers, salesmen, and commercial agents in Manchuria are usually well versed in the Manchurian dialects. That Japan is in a position to place in the field a force of men able to carry on commercial transactions through the medium of the Chinese 
language is the result of organized efforts. Besides the Foreign Language School at Tokio, whose curriculum includes the Chinese dialects, there is the Tokio College of Commerce which encourages the study of the commercial language and usages of China. In addition to these institutions, the Toa Dobun Kwai, a society whose main object is the promotion of friendly relations between Japan and China, maintains two schools, one in Tokio, the other in Shanghai, each devoted to instruction in the Chinese language. It is from among the graduates of these various institutions that Japanese commercial agents in Manchuria are recruited.

The Toa Dobun Kwai has rendered Japan a more valuable service than the mere dissemination of knowledge of the Chinese language. With the coöperation of the graduates from its two schools, engaged in various mercantile business throughout China and Manchuria, the society has been making thoroughgoing investigations into the economic conditions in China. The result of these investigations has been published in a series of books, dealing with Chinese commercial usages, geography, money and banking, articles of trade, means of transportation, and all that concerns the trade conditions in the Celestial Empire.

Another important agency in Japan's economic progress in Manchuria is the establishment of commercial sample museums in various principal towns in that country. The establishment of such museums for advertising Japanese products in foreign countries dates from I 895, when the Japanese government installed museums in Vladivostok, Odessa, Bombay, Singapore, Shasi and Mexico. Since then Japan has followed the policy of establishing commercial museums mostly in Oriental 
countries. Before the Russo-Japanese war there were such establishments in Shasi, Hankow, Chunking, Bombay, Singapore and Bangkok. At that time Newchwang was the only Manchurian town which had a Japanese museum, but inmediately after the war this was reënforced by new establishments in Tairen, Liao-yang, Mukden and Tie-ling. The museums are placed under the control of the Japanese consulates, but are left in charge of merchants properly qualified to act as a medium for the conclusion of transactions between Japanese and foreign merchants or manufacturers.

Japanese consuls in foreign lands, like those of other countries, are required to submit to the home government reports on the commercial conditions of the respective countries where they are stationed. But the consuls are not always possessed of the technical knowledge and experience necessary in an intelligent understanding of industrial and commercial conditions, nor are they able to devote ample time to the observation and study of the market. As a means of remedying this defect the Japanese government annually sends abroad a number of capable young men, who are charged with reporting from time to time on the commercial conditions of foreign countries with a view to facilitating the extension of markets for Japanese merchandise. More than forty of such "student commercial agents" are in China and Manchuria, closely studying all matters relating to the commerce and manufacture of the country.

Still another factor which is a great auxiliary to Japan's commercial activities in Manchuria is the advantage which she enjoys over her Western competitors in the matter of transportation. Manchuria lies within three days of Japan by steamer, while it is separated from 
America by the whole length of the Pacific Ocean. What is still more important, Japan has numerous vessels plying between her own and Manchurian ports, whereas America has no regular steamship service of her own to Manchuria. If it be true that "trade follows the flag," how much more truly may it be said that trade follows the mercantile marine. In 1907, eighteen American vessels totalling only Io, 663 tons entered the port of Antung, but in the year following not a single steamer under the American flag appeared in any Manchurian harbor. Let us cast a glance at the following table, showing the number of vessels of various nationalities which entered the three ports of Manchuria during I908:

\begin{tabular}{|c|c|c|c|c|c|c|c|}
\hline & & \multicolumn{2}{|c|}{ Antung } & \multicolumn{2}{|c|}{ Tairen } & \multicolumn{2}{|c|}{ Newchwang } \\
\hline Japanese & & $\begin{array}{l}\text { No. Ves. } \\
\text {. } 298\end{array}$ & $\begin{array}{c}\text { Ton. } \\
147,254\end{array}$ & $\begin{array}{c}\text { No. Ves. } \\
1,327\end{array}$ & $\begin{array}{c}\text { Ton. } \\
95^{\circ}, 439\end{array}$ & $\begin{array}{c}\text { No. Ves. } \\
221\end{array}$ & $\begin{array}{c}\text { Ton. } \\
222,460\end{array}$ \\
\hline English. & e & - 25 & 28,359 & . $\quad 118$ & 192,025 & 286 & 286,65 \\
\hline American & & 0 & 0 & 0 & 0 & 0 & \\
\hline German & & 0 & 0 & I 7 & 27,163 & 12 & I 3,94 \\
\hline Chinese & & . 13 & 4,108 & 81 & 19,521 & 78 & 54, \\
\hline French & & . . 0 & 0 & 0 & 0 & 30 & 23,1 \\
\hline
\end{tabular}

We see that the number and tonnage of Japanese steamers were by far the largest. The table does not include sailing vessels, of which Japan had also a large number plying between Manchuria and home ports. The phenomenal progress of Japanese steamship service to Manchuria, like that to other countries, has been made possible by generous subsidies and bounties granted to shipping enterprise. So important a bearing does this phase of Japan's economic activities possess upon the expansion of her foreign trade that its detailed description may be justified. The bounty fund set apart for the year 1909 amounted to II,I70,255 yen, which was distributed among various steamship companies as follows : 


\section{Company}

Nippon Yusen Kaisha (Japan Mail S. S. Co.) . . 4,503,707 yen.

Toyo Kisen Kaisha (Oriental S. S. Co.) . . . . 1,763,880 " Japan China S. S. Co. . . . . . . 800,000 “

Osaka Shosen Kaisha (Osaka Merchant

Steamship Co.) . . . . . 641,000 "

Mitsui \& Co. shipping department . . . . 230,000 " Others ............. 2,381,668 ".

Again, if we apportion the above sum to the principal lines subsidized we obtain the following figures:

\section{Lines}

Austrian service

Yangtse River service ..........

European service . . . . . . . . .

Seattle service ............

San Francisco service

Far Eastern near-sea routes (North China, Korea,

Vladivostok) . . . . . . .

Japan Sea coasting service .........

Tairen
Annual grant

473,092 yen.

800,000 "

$2,673,895$ “

654,030 "

$1,013,880$ “

530,000 “

351,000 "

$\mathbf{1} 40,000$ “

As this table shows the Manchurian port of Tairen alone receives an annual grant of 140,000 yen, while North China (including Manchuria) and Korean service shares the major portion of an annual subsidy of 530,000 $y e n$. Let us see how these subsidies and bounties are granted.

An ocean-going steamer with a displacement of $\mathrm{I}, 000$ tons and a speed of ten knots is entitled to the prescribed rate of bounty according to the distance covered and the tonnage of such vessels. The bounty for a steamer of $\mathrm{I}, 000$ tons is at the rate of twenty-five sen per ton per ten knots, the rate subject to increase by ten per cent. for every additional 500 tons, and by twenty per cent. for every additional speed of one knot per hour. For a steamer of not less than 6,500 tons and with a speed of eighteen knots per hour the maximum limit of bounty corresponds 
to the rate allowed to a ship of $6 ; 000$ tons with a speed of seventeen knots. The full rate is granted only to steamers not older than five years, a reduction of five per cent. being made for every one year exceeding the above limit. The above schedule applies only to home-built steamers, foreign-built steamers being entitled to half rate. Besides the $11,170,255$ yen granted to various steamship companies in 1909, Japan in the same year appropriated $1,995,440$ yen for the encouragement of ship-building at home and 25,000 yen for the training of seamen.

I have reviewed, though in a succinct manner, Japan's method of commercial operations, and in doing so I believe I have explained the secret, if secret it can be called, of her commercial success in Manchuria. If American trade in that country has suffered any loss from the practice of that method, it is not the Japanese who are to blame. But has America really been a loser in the commercial competition in Manchuria? This question we shall try to answer in the next chapter. 


\section{VII}

\section{AMERICAN TRADE IN MANCHURIA AND THE "OPEN DOOR"}

T 1904 American cotton shirtings imported to Manchuria through the port of Newchwang aggregated 185,385 pieces; in 1908 they decreased to 63,097 pieces. Again, American cotton sheetings and drills imported through the same port in 1904 were $1,140,620$ and 442,29I pieces, respectively; four years later there were only 5 I5,I93 pieces of sheetings and 194,570 pieces of drills imported from America. If imports of other American goods such as flour, kerosene-oil and tobacco are declining at the same rate, who knows but that American trade in the country may before many years sink into insignificance?

The question arises: "Is this unhappy situation due to the Japanese advance in Manchuria?" With courteous bows and unfailing smiles Japan stands at the "open door," and invites all nations to come and share the benefit of Manchurian trade. Indeed she seems to make a speciality of the "open door" and equal opportunity for all nations, but once within the threshold, do not the Western guests find themselves jostled and elbowed by the hostess?

Naturally there is growing up in the American mind a deep apprehension that American trade is being gradually eliminated from Manchuria by questionable tactics which Japan does not scruple to employ. We can fully understand, and even sympathize with, the Americans in 
their uneasiness as to the future of their Manchurian trade, when we consider that American interests in Manchuria are, or at all events have been, par excellence commercial. It was undoubtedly with a view to alleviating this popular anxiety that the Tokio and Washington governments exchanged diplomatic notes, reasserting their mutual intention " to preserve the common interests of all powers in China by supporting . . . the principle of equal opportunity for commerce and industry for all nations in that empire." But when a nation is seized with distrust and suspicion, its trust cannot be restored by the reassurances of diplomats. A treaty or a convention may clear away misunderstandings between governments, but in this blessed age of democracy the masses of people must be reckoned with in the adjustment of international relations. It often requires years of earnest efforts and assiduous toil on the part of the broad-minded and public-spirited to set aright the esprit de corps of the populace which has been misled by illadvised counsellors. Is it any wonder that the diplomatic notes exchanged between Washington and Tokio have apparently failed to attain the end they had in view? I have already explained in the foregoing chapter that Japan's modus operandi in seeking supremacy in Manchurian trade is perfectly legitimate, so that no other nation has any right to complain; it remains for me to inquire how far, if at all, Japan has made incursion into American trade in Manchuria.

America's staple imports to Manchuria consist of flour, kerosene-oil, tobacco, and cotton goods. But before dealing with these articles let us consider American import of railway materials to Manchuria, for these, while not staple import, have been, and, if America will not 
unnecessarily assume the attitude of a provocateur towards Japan, will for many years to come constitute one of the important items in the list of American imports not only to Manchuria but also to Korea.

According to the United States consul at Tairen the South Manchuria Railway Company purchased of America in 1907 railway materials to the value of $\$ 6,721,959$, of which $\$ 281,089$ was for machinery, $\$ 6,288,922$ for rolling stock, and the remainder for general railway material. Never in the history of Manchuria had so large an amount of American railway material been imported to the country. Russia built her Manchurian railways mostly with her own material, the Imperial Railways of North China used exclusively British material; it was only after Japan entered the field that American rails and cars began to be used in Manchuria. The railway materials imported in 1907 have been utilized for the improvement of the main line of the South Manchuriasystem, measuring some 500 miles. But the significance of the American railway-material trade in Manchuria lies not so much in what it has been as in what it promises to be. The light railway between Mukden and Antung will soon be converted into a standard gauge, which means that Japan must place more orders for rolling stock in some foreign country. Then again, the construction of the KirinChangchun line will soon be completed. This line, as we have already seen, is to be extended to Hoi-ryon on the Korean border, and thence to the port of Chong-jin on the Sea of Japan. In this connection it is well to remember that Japan has conceived an extensive scheme for covering the Korean peninsula with a network of iron road, for Korea has been and will be as good a market for American railway material as has been Manchuria. 
But there are untoward circumstances, which, if permitted to prevail, may prove prejudicial to American trade in Manchuria and Korea. The first of such circumstances is engendered by the utterances and agitation of those very Americans whose speciality is the advocacy of America's commercial expansion in the Far East. Closing their eyes, wittingly or unwittingly, to the real status of American enterprise and trade in Korea and Manchuria, these apostles of American commerce have made Japan a target of slanderous criticism. The thoughtful class of the Japanese understands that such criticisms do not represent the concensus of opinion among the majority of Americans, but who can venture to guarantee that Japan is absolutely free from demagogues and agitators, who may not scruple to mislead that all-powerful individual, the "man in the street "? Besides, in this "iron age of hurry-skurry" much of our reading must be taken running, and he who runs does not take the trouble to meditate upon what he may read. And here lies the point of danger. Unwarranted utterances of irresponsible critics, published in newspapers, magazines and books, may as much be read by the man who runs as by the man who thinks, and thus readily be converted into a leaven which may ferment ill-feeling in the mind of a whole nation. If America allows the agitation of her indiscreet critics to reach such a pitch as to alienate Japan's sympathy from her, who can blame the Japanese if they divert the patronage, which they have bestowed upon American goods, in favor of other countries?

However that may be, I must emphasize the fact that in the future American rails and rolling stock may not be able to monopolize the Manchurian market, as it has done 
hitherto. While Americans have been indulging in groundless complaints about Japanese methods, and have been neglecting to suggest any practical means for removing the handicaps which America herself placed in her own path of commercial progress, German and even Russian concerns have been active in the field with the obvious intention of enticing away Japanese patronage of American railway materials. With the shrewdness and energy characteristic of her, Germany has been pushing her trade in Japan through her local agencies established in important towns throughout the country. In a recent issue of the official German journal, the Continental Correspondence, it is noted that " the Tokio agency of the Siemens-Schuckert Works, with branches at Osaka and in the interior, has grown to such dimensions that a division into separate minimum current and intense current agencies is contemplated. A number of German machine factories that have representatives in Japan are sending out a staff of experts for service on the spot. Evidently the economic conditions of Japan have settled down sufficiently since the war to secure a rapid development of its industrial life, and German enterprise will not miss its chance."

The activities of German interests have evidently been successful, for where only a few years before America and England had been almost the only countries exporting railway materials to Japan, in 1907 Germany sold Japan railway materials to the extent of $\$ 1,250,000$, a portion of them having been utilized in Manchuria. As for Russian competition in the railway-material trade, it may be reasonably predicted that it will assume a serious aspect in the near future, although it is as yet an insignificant factor. During the late war many new steel 
mills and car factories sprang into existence in Russia, while those already in business greatly enlarged their plants. Now that the war has passed into history, the Russian manufacturers of railway material must find markets for their product in foreign countries, or their plants will lie idle, if nothing worse. It is undoubtedly with a view to allaying this unhappy condition that several Russian factories have been eagerly seeking the patronage of the South Manchuria Railway. When Baron Goto, Japanese Minister of Communications, was in St. Petersburg in the spring of 1908 , various Russian concerns took particular pains to impress the Japanese statesman with the advantage of ordering railway materials from Russia. Whether or not their efforts have had any influence upon the Baron's mind, it is a noteworthy fact that a considerable amount of Russian rails is now found in South Manchuria. And as luck would have it, American diplomacy has unconsciously forced Russia and Japan into each other's arms, thus creating a more favorable situation for the Russian railway-material trade in Manchuria. Meanwhile, American steel mills and car factories are apparently doing naught in the way of staying German and Russian incursion into their field. Can A merican manufacturers, enjoying as they do a great advantage in transportation over Germany and Russia, afford to abandon their Manchurian market to these European competitors?

Russian competition is not confined to the railwaymaterial trade; Russia even dreams of driving out American flour from Manchuria. This leads us to the consideration of the flour trade in Manchuria.

As I have stated in the foregoing chapter, Harbin, the Russian metropolis of Manchuria, has eight flour 
mills with a daily capacity of $1,600,000$ pounds. If these mills are all kept in operation Russia must necessarily find in Southern Manchuria an outlet for their output. The most important section of Manchuria from a commercial point of view is its southern section. Northern Manchuria, though more than twice the size of Southern Manchuria, has but one-third its population. Now Harbin has for its background the least populated part of the country, and unless Russian flour seeks a market in Southern Manchuria, the Harbin mills will hardly ever hit upon a profitable working plan. To estimate the amount of flour annually consumed in Southern Manchuria, we glance at the latest returns of the Chinese Maritime Customs.

In 1908 the total amount of flour imported to Manchuria through Antung, Tairen, and Newchwang, through which the foreign trade of Southern Manchuria is carried on, was about 426,574 piculs, or about $56,876,500$ pounds. Although the customs returns do not distinguish between American flour and flour from other countries, we learn from the reports of the Tairen Commercial Museum that nearly five-sixths of flour imported through that port is from America; and it is safe to say that the same proportion holds true with regard to the flour trade of the other two ports, Antung and Newchwang. The annual import of American flour to Southern Manchuria, therefore, must amount to some $47,396,270$ pounds. It is this trade which the Harbin mills will try to wrest from America. As yet the price of Harbin flour is a little higher than American flour, while its quality is inferior to the latter. American flour of medium grade can be laid down in Newchwang at about Mexican $\$ 1.90$ per fifty pounds, while Harbin flour of the first quality, which is no better 
than ordinary American flour, costs about Mexican $\$ 2.10$ per fifty pounds. But before long the Russian mills will learn to produce a better grade of flour at a less cost, and when that time comes, they are bound to become powerful rivals of American flour merchants in Manchuria.

In this connection it may be well to note that Japanese flour is imported into Manchuria in small quantities. But as the raw material feeding Japanese mills is mostly American, the United States cannot be regarded as the ultimate loser even if Japanese flour is exported to Manchuria to any considerable extent.

As to the kerosene-oil trade we have more accurate figures to show the extent of American import. In this field America's only rival is the German concern, the Asiatic Petroleum Oil Company, which imports Sumatra oil. In 1908 the total amount of kerosene-oil imported to Manchuria was about $8,999,2$ I I gallons. Of this total, 7,236,260 gallons were from A merica, and $1,762,951$ gallons from Sumatra.

Now we come to the consideration of the tobacco trade in Manchuria. The British-American tobacco trust, with its head office in Shanghai, maintains a factory in Mukden which is the source of the trust's commercial operation in Manchuria. During the RussoJapanese war the presence of a large number of Japanese soldiers in Manchuria naturally favored the importation of Japanese tobacco, and it seemed, for a while at least, that Japan would ultimately wrest from the AmericanBritish trust supremacy in the tobacco trade in that country. But the success of Japan in this field proved ephemeral. A foothold so firmly established as that of the trust could not be dislodged so easily. As the Mikado's army withdrew from the field, and as Man- 
churia returned to the pursuit of its normal industry, the American-British syndicate again became the master of the situation, and the Japanese tobacco trade gradually dwindled before its increasing influence. The invulnerable position which the trust secured in Manchuria is largely due to the up-to-date business methods which it has consistently pursued. To cite an illustration, the trust carries stocks in warehouses at various points where the local dealer can obtain what he desires without delay, with no letter writing nor annoying preparation of drafts and remittances. All the dealer has to do is to go to a bank or other authorized agent, pay the fixed price for the amount he wants, and receive a warehouse order for the goods. This order is honored at the warehouse and may be used as a check on the bank or agent, the latter remitting direct to headquarters.

This practice is followed not only in Manchuria but also in Korea, where the trust has an extensive business. Further details of the American-British enterprise will be described in connection with American trade in Korea. For the present we must leave the trust and pass on to the cotton-goods trade in Manchuria, in which field America is striving to maintain supremacy.

The principal cottons imported to Manchuria are shirtings, sheetings, drills and jeans. Until fifteen years ago Great Britain contributed most to the cotton-goods trade of Manchuria, but it was her ill-fortune to be gradually superseded by America. The reason for this change is obvious. The rigorous climate of Manchuria and North China naturally favors the importation of the heavier makes of goods, which are exactly the kinds America has been sending to Manchuria. The American goods have another merit in that they withstand 
hard washing much better than do the English goods. The difference in price, though rather slight, has also assisted in turning the scale in the eyes of the Chinese merchants and consumers in favor of the American goods. England still held supremacy as regards shirtings, but in sheetings, drills and jeans she was all but driven from the field by the United States. Then came the war, and a new factor was injected into the situation.

Soon after the war, the leading Japanese cotton manufacturers, with the backing of the house of Mitsui, the greatest Japanese firm engaged in foreign trade, organized themselves into a guild with a view to pushing their trade in Manchuria. Their organized efforts were soon crowned with success. To-day Japanese cotton goods can be laid down in Manchuria at less than it costs to import American goods. For instance American sheetings cannot be retailed in Manchuria at less than fourteen yen fifty sen per piece with a weight of thirteen to fourteen pounds, while Japanese sheetings of practically the same quality are sold at thirteen yen eighty sen per piece. It is estimated that the annual demand of Manchuria for sheetings alone is as large as ten million yen, and it is in this special field that the Japanese manufacturers have been most active. To indicate how successfully Japan is pushing her cotton-goods trade in Manchuria, the following table is prepared, comparing the respective volumes of American, British, and Japanese manufactured cottons imported through the port of Newchwang during 1907 and 1908 :

\begin{tabular}{lrrrrrr} 
& \multicolumn{2}{c}{ American } & \multicolumn{2}{c}{ British } & \multicolumn{2}{c}{ Fapanese } \\
& 1907 & 1908 & 1907 & 1908 & 1907 & roo8 \\
Shirtings & 3,590 & 63,095 & $32,33^{2}$ & 67,253 & & 1,800 \\
Sheetings & 258,460 & 515,193 & 3,520 & 15,650 & 98,940 & 151,400 \\
Drills & 194,570 & & 3,075 & 1,840 & 9,200 & 52,200 \\
Jeans & 54,102 & 63,990 & 42,979 & 124,996 & &
\end{tabular}


It is a remarkable fact that a nation which as late as 1900 laid down in Newchwang practically no manufactured cottons should eight years later import sheetings to the extent of $15 \mathrm{I}, 400$ pieces, as well as 52,000 pieces of drills and $\mathrm{I}, 800$ pieces of shirtings. While the Japanese trade has made such a great stride, the American trade has been gradually declining. Witness the following table, which shows the import of A merican manufactured cottons through Newchwang from 1903 to 1908 :

\begin{tabular}{lrrrrrr} 
& \multicolumn{1}{c}{1903} & 1904 & \multicolumn{1}{c}{1905} & 1906 & \multicolumn{1}{c}{1907} & \multicolumn{1}{c}{1908} \\
Shirtings & 38,470 & 85,385 & 79,216 & 29,632 & 3,590 & 63,097 \\
Sheetings & $1,033,089$ & $1,140,620$ & $2,252,165$ & 336,951 & 258,460 & 515,193 \\
Drills & 596,625 & 442,291 & 974,557 & 65,958 & 130,540 & 194,570 \\
Jeans & 92,410 & 80,350 & 151,023 & 102,968 & 54,102 & 63,990
\end{tabular}

The significance of this table will be brought home more forcibly to the Americans when it is remembered that in 1899 American sheetings imported through Newchwang amounted to I,IOI,765 pieces, while American drills and jeans imported in that year were as many as 584,877 and 29,630 pieces, respectively. Besides the trade returns of Newchwang there are the returns of the Tairen and Antung customs to be considered, but the statistics already presented are sufficient to indicate the relative positions of the Japanese and American cottongoods trade in Manchuria.

In the previous chapter I have stated that cheap labor is not among the most potent factors in promoting Japanese trade in Manchuria. Yet the low cost of production, made possible by abundant supply of cheap labor, is of no small advantage to Japan. The New York Times, predicting five years ago a coming economic struggle between America and Japan, made the following pertinent remarks : 
"Southern cotton mills operated by water power and employing cheap labor have already demonstrated their ability to sell their product in China in competition with Manchester. But southern mills pay their operatives from five to seven dollars a week, while Japan pays her male operatives seventeen cents a day, and her female operatives ten cents. The wage scale puts the South out of the running. Fall River is not in the competition at all. With cotton at about twelve cents a pound in 1904, the cost of turning out print cloths in Fall River was three and three-eighths cents a yard. Japan can underbid Fall River by at least a cent in the yard. Our cotton yarns cost us forty per cent. more to produce than Japanese yarns cost. But the material, not the labor, is the main element of cost in cotton goods and yarns. In manufactures of a higher complexity the difference in labor cost must be vastly greater."

Other things being equal, it is low price which controls the market. But in the case of American-Japanese rivalry in Manchuria other things are not equal. So far from it, everything seems to favor the advancement of Japanese trade. The Japanese did not create these favorable circumstances by iniquitous, underhand means: they merely benefited themselves by what nature bestowed upon them. Japan's geographical situation, the abundant supply of cheap labor at her disposal, her familiarity with the use of pulse, a certain similarity existing between the Chinese and her own languages-are not these all conditions prescribed by nature, in whose hands the Japanese are but an instrument? As the New York Times, in the same editorial we have just quoted, fitly observes, if America will have the losing end of the bargain in the Far East, she cannot complain that Japan has 
not given her a square deal. We realize that when once we begin to talke away the Chinese trade of Western nations, the latter will cease to be effusive, sympathetic and cordial towards us. But that is one thing we cannot help. We are poor; our natural resources are limited; we cannot grow wheat and corn, raise hogs and cattle, and "live on the fat of the land," as you of great America can; no one has made us a handsome bequest so that we might live comfortably without worrying about the morrow. And like all poor families ours is increasing with embarrassing rapidity-such is the irony of fate. What will become of our ever-increasing children, if we do not manufacture and export as best we can? If we entice away your customers by underselling, that is no fault of ours. It would be unreasonable-worse, it would be cruel-to condemn the man who lives by the honest sweat of the brow without in the least violating the common dictates of justice and honor. Japan's case in Manchuria is the case of the poor man who is forced to toil hard and practice strict economy. If the Western world cannot tolerate Japan's commercial advance in Manchuria simply because its pockets come into the reckoning, no more can Japan afford to stay home idle in order that the Western nations may have all the chance they want. 



\section{B OOK I I}

\section{The Korean Question}





\section{VIII}

\section{WHY JAPAN OCCUPIED KOREA}

$\mathrm{H}$

ALF a decade has elapsed since the establishment of the Japanese protectorate over Korea, and the interval has witnessed the publication of numerous books and articles dealing with the Korean question. It may therefore be presumed that the public has been afforded an ample opportunity to understand the sequence of events which impelled Japan to choose the course she did. But the truth is that the Western world has not yet grasped the true significance of the Korean situation which inevitably led up to the Japanese control of the peninsula. To the mass of literature which proceeded from the pens of Western writers far from friendly towards Japan, some of the Japanese writers, who undoubtedly meant to defend the cause of their country, have unwittingly added material which, instead of clearing misconceptions, has assisted in intensifying them. Let me note a trenchant essay of a well-known Japanese writer which has been widely quoted as indicating Japan's ruthless method of dealing with Korea.

Writing in an important New York monthly, this Japanese writer declares that the Japanese are doing in Korea "just as the Americans have done to the Indians," and adds: "Nippon has joined the household of great powers ; she has become civilized." The assertion is straightforward and fearless, yet its tone savors of cynicism and is scarcely calculated to impress the reader with the inevitable situation which impelled the Japanese to 
establish a protectorate over Korea. Furthermore, when he serenely says that "we have gone over into the back yard of our neighbor and are telling him to kindly move on, simply because we need his home," he becomes plainly misleading, for such a statement is hardly warranted by the facts which necessitated the obliteration of Korean autonomy. To the Japanese, the control of the peninsular empire was no matter that could be made light of, as is done by this writer; it was the inevitable outcome of the hopeless corruption and irredeemable impotence of Korea, which defied the repeated attempts of the Japanese to put her on her feet. These attempts, though not wholly disinterested, were undoubtedly sincere and earnest, for it was Japan's conviction that her interests, aye, her very existence, could be maintained only by maintaining Korea's independence, or by preventing her from passing into the hands of a third power. The conviction may have been mistaken, but Japan could view the matter in no other light; and in following this conviction she did not hesitate to sacrifice countless lives and incur endless drain upon her treasury. It is not "simply because we need the home of our neighbor" that we are in Korea : on the contrary, we told him again and again that he must keep his home in respectable condition; that he must clear up his premises, so that no powerful neighbor would have an excuse for doing this for him. If we seemed to recant, it was simply because the home seemed certain to pass into the hands of some other party, extremely dangerous to us, unless we took care of it ourselves. To bring home this fact to the reader it is necessary to survey briefly the history of diplomatic relations between Japan and Korea.

It is commonly known that the United States was the 
first Western power to receive a Korean minister; but not many people are aware that of all the nations Japan was the first to recognize the independence of Korea. It was early in the seventies of the past century that Japan first sent her envoy to the court at Seoul only to meet a rude rebuff at its portal. Not only did Korea foolishly refuse to enter into friendly relations with Japan, but she fired, for no plausible reason, upon a Japanese war vessel which was peacefully at anchor off Chemulpo. This incident furnished Japan the opportunity to force open the door of the hermit nation, and wrest the treaty of peace and commerce of $\mathbf{I} 876$. The acquiescence of Korea in this treaty forms the pivotal point in the history of the peninsular kingdom, for the instrument was the first treaty ever entered into by Korea with any foreign power. But its greatest significance lay in the fact that it dealt with Korea as an independent state, and thus ignored the suzerain power which China claimed to possess over the peninsula. Article I of this treaty declares that "Chosen (Korea), being an independent state, enjoys the same sovereign rights as does Japan."

The conclusion of this treaty naturally placed a heavy responsibility upon Japan's shoulders, for her adherence to the letter and spirit of the treaty must necessarily stir the ire of China, which was then universally regarded as immensely more powerful than Japan. Having emerged from tremendous political upheaval only several years before, and having just suppressed a formidable insurrection, Japan was far from prepared to run single-handed the gauntlet of such a powerful enemy. Following Japan's lead, several Western powers likewise concluded similar treaties with Korea, but their advocacy of Korcan independence was only half-hearted, for did not these 
Western powers accept without protest the note from the Seoul court, stating that these treaties would make no change to the status of Korea as a vassal state of China? Not only this, but England and Russia practically departed from the spirit of their treaties with Korea, when on the occasion of the Russian occupation of the Korean island of Chee-wen (Port Hamilton) in I 885, these powers negotiated not with Korea, the rightful owner of the island, but with China. Even the United States, which had the privilege of receiving the first envoy Korea ever sent to the West, made no efforts to prevent China from recalling and punishing the minister.

Alone and unaided, Japan boldly undertook to uphold the independence of Korea in the face of an enemy, which had brought pressure to bear upon the Seoul court like an incubus. It soon became evident, however, that the peninsular people were decrepit beyond the point of renovation. Following upon the heels of the treaty of 1876 , a spirit of reform in the internal affairs of Korea flushed the sky with a light of hope, which seemed to forestall the approach of sunshine after an arctic winter. A Japanese officer was invited to reform the degenerate army of Korea, and a few progressive Koreans were admitted into the government.

Apparently, Korea was committed to the cause of progress. But it soon transpired that these progressive statesmen were merely dupes of a designing clique, which had made a feint of espousing a reform policy simply as the means of ousting from power the opposing clique, led by the arch-chauvinist and conservative, Prince Tai-wun. Only a spark was needed to kindle a fierce factional feud. That spark was found in the military riot of 1882 , caused by the shameless peculation of a 
few officers, who lined their pockets at the expense of their soldiers. At the covert instigation of Prince Taiwun, the rebels forced their way to the palace, intent upon murdering all those who were in power, not excluding even the queen, the avowed antagonist of the conservative prince. With the utmost inconsistency, the insurgents also murdered the Japanese officer entrusted with the reformation of the Korean army, burned the Japanese Legation, and forced the Mikado's minister, with his staff and his countrymen in Seoul, to beat a retreat to Chemulpo. This unfortunate riot resulted in an agreement, by which Korea was to pay Japan an indemnity of 550,000 yen; but when she paid its first installment of 150,000 yen, Japan magnanimously relinquished her claim to the remainder of the indemnity. In this matter Japan was actuated by her sympathy with the depleted condition of the Korean treasury as much as by the less altruistic desire of instilling in the Korean mind a friendly sentiment towards her. Some twenty-five years later, the same motives actuated the United States to relinquish her claim to the greater portion of the Boxer indemnity.

Again the hope of Korea's regeneration was held out only to fade away like the flash of a meteor. A coterie of progressive Koreans, who returned from Japan imbued with progressive ideas, organized themselves into what was known as the Independence Party, whose object was the consolidation of Korean independence by adopting progressive measures. The king himself seemed well disposed to heed the advice of these reformers, and endorsed the invitation of two Japanese publicists as advisers to the court. Acting upon her avowed policy, Japan backed the Independence Party and all the move- 
ments calculated to further the cause of progress. At the same time, however, Japan was careful to impress these progressives with the danger of "forcing the pace," for she was well aware that a state like Korea could not be roused all of a sudden from a torpor of centuries. But the inexperienced radicals, to whom the regeneration of their country seemed a case of "now or never," were too impatient to refrain from rash measures, while the conservative clique was employing all its resources in its attempt to expel the radical element from the administration. At this juncture, China threw her influence on the conservative side of the scale, and the unsuccessful coup, resorted to by the indiscreet radicals, left the government in the hands of the reactionaries. Again the Japanese Legation was reduced to ashes, and a number of Japanese officers and residents were murdered.

The decade following this ruinous upheaval witnessed a continuous encroachment by China upon Korean administration, and the gradual elimination of Japanese influence from the peninsula. All this while, however, Japan did not acquiesce in the situation, and protested time and again against China dealing with Korea as her tributary state. As China was thoroughly intrenched in the Hermit Kingdom, so firmly was Japan determined to uphold the independence of the helpless nation. The crash between the two powers was only a matter of time. By I 894 the little islanders of Nippon were thoroughly prepared to settle the matter by the arbitrament of the sword. Having perceived that the internal administration of Korea had been going from bad to worse, Japan, in that year, proposed to China that the two powers coöperate in executing necessary reforms to maintain the integrity of the peninsular kingdom. 
This proposition China met with a flat refusal. The result was the war of $1894-1895$, in the wake of which Korea was left in Japan's hands. But even the shock of the great war that swept through their own country proved powerless to awaken the dull people of the peninsula. Unheeding Japan's advice to rehabilitate their internal affairs along new lines, they did nothing but quarrel among themselves, or, at best, play at all manner of silly pastimes.

Soon after the war Japan sent to Korea one of her ablest statesmen in the person of Count, now Marquis, Inouye, with the instruction to urge upon Korea a reform programme, of which the following items were the main features: (1) the affairs of the Royal Household should not be confounded with those of the government; (2) the sovereign must rule only in accord with the principles laid down in the laws; (3) there should be one, and only one source of authority, which means that the consort or private relatives of the sovereign should not be allowed to interfere with the affairs of state; (4) the respective powers of the different departments of the government must be clearly defined, and all officers must be subject to disciplinary measures; (5) the army must be reorganized along modern lines; (6) taxes must be collected only at rates fixed by the law. To facilitate the execution of this reform programme, Japan loaned Korea 3,000,000 yen. But all this sane advice fell upon a deaf ear, and the Koreans went repeating the old story of plots and counter-plots among themselves. This unfortunate state of things was largely responsible for the assassination of the queen on October 8,1895 , although the Japanese government itself could not shirk the responsibility in so far as it failed to foresee that the ap- 
pointment to the post of minister to Korea of an indiscreet, unscrupulous man might entail an embarrassing situation.

The political situation in Korea, already disturbed by the continuous factional feuds and the consequent assassination of the queen, became worse confounded by the appearance on the scene of Russia with all her sinister designs, aimed at the disintegration of Korea. The indolent, unpatriotic people, weary of Japan's insistence upon reform, readily handed themselves over to Russia, which would have none of reform and progress in the peninsula, but would let things go along the old way, knowing that this would admirably serve her purpose. Thus the curtain rose on a new scene in February, I896, when the weak-minded king practically removed his court to the Russian Legation, and immediately ordered the murder of all the ministers known to be friendly towards Japan. Thenceforward Russian activities in Korea became more and more ominous, and seemed to lead the peninsular nation into the quagmires of degeneration. The Muscovite diplomats made the most corrupt Korean officials tools in their hands, and through them obstructed the Japanese policy of reform at every point.

Anxious to check Russia's further encroachment upon Korea, Japan sent Marquis Yamagata to St. Petersburg in May, I896, with the mission of defining the respective attitudes of the two powers towards Korea. This mission, however, was unable to accomplish anything important, except the agreement that in case Korea had to have recourse to foreign aid in carrying on her internal reform, both Russia and Japan would lend, by mutual accord, their assistance to that country. From a diplo- 
matic point of view this understanding meant a defeat of Japan, inasmuch as Japan thereby plainly accredited Russia, which had no real political or economic interest in the peninsula, with the same advantageous position as she herself held.

The worst of it was that Russia had no intention of adhering to this arrangement. From the outset it was plain that the Muscovite diplomats in the Far East embraced no moral code save that of the dying patriarch, who offered this advice to his first-born: "My son, get money-honestly, if you can, but get money." By dint of chicanery and subterfuge, they succeeded in reversing the above agreement. As it became more and more evident that the Russian absorption of Korea was merely a matter of time, Japan became restive and made another effort to stay Russian encroachment. The result was the agreement of April 25, 1898, which contained the following article:

"The Imperial governments of Russia and Japan recognize definitely the sovereignty and entire independence of Korea, and pledge themselves mutually tamstain from all direct interference in the internalaffairs of that country."

But all these pledges and agreements were of no use, when Russia's ultimate plan was to add Korea to her own map. The matter was a matter that should be discussed only in the language of shot and shell, if Japan was to convince the great White Czar of the unjustifiability of his pretentions. The war that ensued was the final act in the great drama of the Russo-Japanese rivalry in Korea; and the public must be sadly deficient in political insight if it does not perceive that the war and the consequent establishment of a Japanese protectorate over 
Korea were forced upon the Mikado's Empire by the necessity of safeguarding her vital interests, indeed her very existence.

The war left Japan in a position to act in Korea ad libitum. But before assuming the direct control of Korean administration, Japan exhausted all her good offices in her attempt to maintain Korea's independence. Thus, in February, 1904, when the Russians in Manchuria were retreating before the onslaught of the Japanese, Japan concluded a protocol with Korea, in which the Seoul court promised to adopt the advice of the Tokio government " in regard to improvements in administration," while the Mikado's government pledged itself "to ensure the safety and repose of the Imperial House of Korea," and to "guarantee the independence and territorial integrity of Korea." In pursuance of this protocol, Korea invited Mr. T. Megata as financial adviser, and Mr. D. W. Stevens, who was assassinated by a Korean fanatic in San Francisco early in the spring of 1908, as diplomatic adviser. The Tokio administration spared no pains in urging upon the Korean ruler the necessity of administering the government in accord with modern principles. But the venality and supineness of the Korean officials had become such that any amount of good advice proved of no avail. Far from sincere in coöperating with the Japanese in carrying out administrative reforms, they hindered them at every point by resorting to plots and intrigues, in which they were past masters. Instead of endeavoring to improve the conditions of their own country, they foolishly conspired to subvert the new order of things by invoking the assistance of a third power. It was, therefore, inevitable that in November, 1905, Japan should assume the control of 
the foreign affairs of Korea, sending Prince Ito to Seoul as resident-general, who was invested with the power to direct all matters relating to the external relations of the country.

This episode, however, made no change in the internal affairs of the country. The Korean emperor and officials still enjoyed initiative power, and were at liberty to adopt or reject Japan's advice as they pleased. And thus the Japanese were repeating the same experience, the uselessness of which had been indisputably proved during the thirty years that preceded. But at last Japan's patience was exhausted, when, in the spring of 1907, the Korean emperor again sent his emissaries abroad, this time to the Hague Conference, hoping to embroil Japan in international complications over the disposition of the Korean question.

As an evidence that the Korean is a born intriguer, it may not be amiss here to quote no less an authority than Dr. Horace N. Allen, who spent twenty-two years in Korea, and who enjoyed the unique privilege of being a personal friend, physician and adviser to the Korean emperor. Discussing in his book, "Things Korean," the characteristic of the Koreans, this sympathetic writer says :

"Travelling through the country one often notices at a hamlet two or more men off by themselves, engaged in whispered conversation. These men are surely plotting to gain some advantage over another. Entertain an official alone, even in a large room, and he will edge up to you and begin to whisper. It is the same manifestation of the native aptitude for intrigue, which makes them excellent as starters and destroyers, but unsatisfactory as sustainers of an undertaking. . . . The 
villagers scheme against a successful neighbor; the court official pleads for the influence of the foreigner to enhance his own power at court; in both cases it was the same game of politics in all its petty meanness."

This aptitude for intrigue as well as "the habit of not doing to-day that which may be put off till to-morrowa day that never comes, since when it arrives it is still to-day" - these are the factors which set at naught all the efforts of the Japanese for the betterment of the Korean administration by means of friendly advice.

And thus the curtain went up on the last act of the Korean drama, when in July, 1907, Japan despaired because of the treacherousness, impotency and indolence of the Korean ruler and officials, wrested from them an agreement, conceding to her the control of internal affairs of the peninsula. In this agreement it is stipulated (I) that the Korean government shall act under the guidance of the resident-general in all matters relating to administrative reform; (2) that in all matters relating to the enactment of laws and ordinances, and in all important matters of administration, the Korean government must obtain the preliminary approval of the residentgeneral; (3) that there shall be clear differentiation of the executive and the judiciary; (4) that in all appointments and removals of high officials the Korean government must obtain the consent of the residency-general ; (5) that the Korean government shall appoint as Korean officials such Japanese as may be recommended by the residentgeneral. In the meantime the emperor, knowing that his game was lost, issued this edict:

"Alas! I have been in possession of my ancestor's throne for forty-four years. Having experienced many disturbances, the administration has not been up to my 
desire, and frequently the ministers were not the proper men. Rumors are daily increasing, and actions are unfit at present. The worry is great, and the danger to the lives of the people and the downfall of the country's progress are greater than ever-fearful and dangerous, like stepping over ice."

With this pathetic declaration, he abdicated on July 18 , 1907, leaving the throne to his son.

This episode virtually ended the Korean tragedy-a tragedy which might never have been enacted had Korea heeded Japan's advice thirty years before. In speaking of the American occupation of the Philippines, Mr. Roosevelt once said: "The inevitable march of events gave us the control of the Philippine Islands at a time so opportune that it may without irreverence be called providential." The same may be said with regard to the Japanese control of Korea. It was " the inevitable march of events" which drifted us into the haven where we now find ourselves. And again with Mr. Roosevelt we must say that "unless we show ourselves weak, unless we show ourselves degenerate sons of the sires from whose loins we sprang, we must go on with the work we have undertaken." Furthermore, the Japanese control of Korea seems far more justifiable than the American occupation of the Philippines, inasmuch as Japan's interests in Korea, political and economic, were immensely more vital than were those of the United States in the Philippine Islands. To the Mikado's Empire, the sacrifice of these interests and the abandonment of Korea to a third power, bent upon territorial aggrandizement seemed to spell a menace to her own existence.

The inevitable sequel to the episode of 1907 was the annexation of Korea by Japan in the summer of 1910 , 
But before entering into the discussion of the annexation and its effects upon Korea and foreign nations interested in that country, let us pause a moment and inquire into American relations with Korea as well as what Japan has done for and in Korea. 


\section{IX}

AMERICA'S DIPLOMATIC RELATIONS WITH KOREA

1 MERICAN-KOREAN treaty of May 22, 1882, in its first article solemnly declares that

"If other powers deal unjustly or oppressively with either government, the other will exert their good offices, on being informed of the case, to bring about an amicable arrangement, thus showing their friendly feeling."

This article, which was long interred in oblivion, was recently brought to light by those American critics who would have us believe that in recognizing the paramount authority of the Japanese over Korea the United States has violated a sacred pledge, and made herself a despicable figure in the eyes of a forsaken people. To such critics it appears that America ought to have abided by this promise, which had never been withdrawn either tacitly or implicitly, and relieved Korea of the incubus of Japanese domination. To me, however, such assertions are little more than platitudes. More than that, I venture to advance the theory that this covenant was virtually nullified not long after its conclusion.

America's intercourse with Korea began in the usual manner. An American schooner was wrecked off the coast of Northwestern Korea, and the surviving crew asked for succor of the local authorities. The appeal met with a generous response from both the officials and the 
public, and the unfortunate sailors were escorted across the Yalu and handed over to the local Chinese officials for safe conduct to Tientsin, where they might find foreign ships on which to sail homeward. This happened in June, I866. A month later another American schooner, the General Sherman, approached the Korean coast on a mission, the true nature of which has never been known. Defying the protests of the natives the vessel forced her way up the Tatong River to the old capital of Pingyang. Scarcely had she reached Pingyang when the freshet caused by heavy rainfalls began to subside, and the vessel soon found herself unable to retreat, for at ordinary times the Tatong permits the passage only of small sampans. With their ship hopelessly aground, the crew were nevertheless too arrogant to refrain from displaying their innate contempt for the yellow man. Some altercation ensued, and the General Sherman soon found herself besieged by fire-rafts which the natives floated down the river. Leaving the schooner to burn, the crew came ashore only to be slain by the natives.

Another American expedition of a questionable nature was that undertaken in 1867 by one Oppert, whose history is not known except that he was an American of German descent. He heard of invaluable treasures being buried in the tombs of Korean emperors, and he fancied he might make a fortune by despoiling one of these tombs. So Oppert fitted out an expedition and sailed from Shanghai for Korea with two armed vessels; but whether the expedition was successful or not is not known, any more than the life of Oppert himself.

All these incidents served to pave the way to the establishment of treaty relations between Korea and the United States. The first expedition to Korea under- 
taken by the Washington government was that of $187 \mathrm{I}$. It was led by Admiral Rogers with a flotilla of five vessels,--the Colorado, Alaska, Bernicia, Monocacy, and Palos. The American government ordered Frederick F. Low, then American Minister at Peking, to accompany Admiral Rogers to attend to the diplomatic part of the undertaking. Low responded to the call, although he was convinced of the futility of any attempt to open the doors of the hermit nation. Late in May of that year the flotilla reached the western coast of Korea, and Admiral Rogers tried to enter into direct communication with the court at Seoul. The attempt was ill-timed, for Korea was then permeated with anti-foreign spirit. The chauvinistic regent, Prince Tai-wun, had used his power more for the persecution of foreigners than for the promotion of the welfare of his subjects. A shrewd man, he suspected that the American fleet came to demand an explanation for the massacre of the crew of the General Sherman, and he resolved to deal with it in a highhanded manner. He was so conceited as to flatter himself that he had men and arms powerful enough to chastise any intruder, for had he not, only a few months before, vanquished a French force which consisted of the very men who had captured the capital of the great Celestial ruler and reduced his sacred palace to ashes? While the American envoys were awaiting a reply from the court, two of their vessels, which were engaged in taking soundings in the estuary between the mainland and the Kanwha Island, were fired upon from the forts on the island. The American vessels responded to the challenge, and took the forts by storm with the loss of a single officer. This untoward event deprived the American envoys of all hope of entering into amicable negotiations with the 
Koreans, and the flotilla steamed down towards the Yellow Sea, leaving Prince Tai-wun and his court in the conceit that the foreigners were, after all, not so formidable as they were thought to be. The concluding act of this drama was the erection in Seoul of a monument commemorating Korea's "victory" over the "foreign barbarians," and forbidding any one to express views in favor of entering into friendly relations with any Western nation.

But it was not many years before Korea had to abandon her time-honored policy of seclusion. This consummation was precipitated by the sudden awakening of Japan, which injected a new force into the political situation in the Far East. The Sunrise Empire, in the dawn of her fresh energies and new aspirations, thought it her duty to bring her backward neighbors, China and Korea, into line with herself, so that the whole Orient might one day rise in one solid mass and declare to the tide of Western aggression: "Thus far shalt thou go and no farther." Korea readily yielded to the impact of Japanese cannon-balls, and the Japanese-Korean Treaty of 1876 was concluded. With the walls of exclusion thus battered down, it was comparatively easy for the Western powers to open trade relations with Korea. In 1882 the United States fitted out a second expedition to Korea with Commodore Schufeldt at its head. The result was the Korean-American Treaty of May 22d of the same year, and General Foote was sent as first American minister to Seoul.

Here we must pause for a moment and consider the first article of this Korean-American treaty, cited at the outset of this chapter. This article provides, as we have seen, that Korea and America are under mutual obliga- 
tion to protect each other's welfare against the encroachment of other powers. The absurdity of such an article ought to be obvious to any one, for it is the chimera of chimeras to presume that a decrepit nation like Korea could come to the rescue, should a great nation like the United States be attacked by a third power. The Hermit Kingdom was as weak and helpless in I 882 as she has been ever since, and one would almost think that it was a bit of American humor which actuated Commodore Schufeldt to put in the foreground of the treaty he drew up a provision whose impracticability was a foregone conclusion. As the years rolled on, the hopeless condition of Korea became more and more evident, until the stage was reached wherein she had to be subject to the rule of either Russia or Japan. It is obvious that when a nation is so utterly destitute of the qualities necessary for the maintenance of its independence, reams of treaties and conventions are of little avail in propping up the decaying state. The question of whether Korea should remain an independent nation was a question which had to be considered not from a legal, but from a political point of view.

To say that the United States had from the beginning no intention to adhere to the spirit of that article would be to charge her with hypocrisy and insincerity, and I, for one, prefer to think that the course of events that followed the conclusion of that treaty revealed to her the hopelessness of Korea's case, necessitating a radical alteration of her policy towards the Hermit Kingdom. It was the same state of things which forced Japan to abandon her first avowal of a purpose to uphold the independence of Korea. However that may be, here we are chiefly concerned with the fact that the recognition 
by America of the independence of Korea was virtually repealed in 1888 , when China, acting upon the pretention that the peninsular country was one of her vassal states, caused the recall of the Korean minister at Washington, against which America launched no protest.

In 1883 Prince Min Yong-ik, the nephew of the queen, accompanied by a number of progressive young Koreans, proceeded to Washington to ratify the newly concluded treaty. Min had been recognized as one of the leaders of the faction which stood for reform and progress, but upon his return home from America in I 884 he cast his lot, for what reason is not known, with the reactionary or Chinese faction, and in consequence was severely wounded by an assassin belonging to the radical party. Three years after the ratification of the treaty Korea decided to install a legation at Washington. At this time China exercised paramount influence over Korea. Li Hung-chang, one of the shrewdest diplomats China has ever produced, had sent his ablest lieutenant, Yuan Shi-kai, to Korea with the secret instruction that he should endeavor by all means to vindicate China's claim for suzerainty over Korea. When, therefore, Yuan learned of Korea's plan to despatch a minister to America he lost no time in launching a vigorous protest against the arrangement, asserting that as a vassal state of China Korea had no right to send her political representative to any foreign country. The Chinese diplomat employed all sorts of tactics from persuasion to threat in the effort to prevent the departure of the Korean minister. But the Seoul court, heartened by American backing, would not yield, and let the minister leave Seoul on his journey to America before Yuan detected the plan. On the morrow of his departure Yuan knew, to his great chagrin, 
that he was outwitted, and hurried his lieutenant down to Chemulpo whence the mission was to sail on the American naval vessel Omaha. He threatened that unless the mission was forthwith ordered back to Seoul he would return to China, intimating thereby that a grave situation would follow. But in reality Yuan had no intention to adopt drastic measures, for he feared that such a course might embroil China in trouble with the United States. The American government despatched the Omaka to escort the mission as far as the Japanese port of Nagasaki, and, what was still more important, an A merican citizen was to accompany the party in the capacity of adviser. This American was no other than Dr. Horace N. Allen, who, having come to Korea as a medical missionary, secured the friendship and confidence of the Korean emperor to such an extent that he was requested to conduct the diplomatic mission to Washington. It was, therefore, small wonder that at the last moment Yuan receded, and allowed the Korean minister to start. At the same time Yuan imposed upon the Korean minister the following conditions: That the Korean minister, upon his arrival in Washington, should first of all pay a call upon the Chinese minister, who would present him to the President; that in public functions participated in by the diplomatic corps the Korean minister should never precede his Chinese colleague; that on all important matters pertaining to the Korean Legation the Chinese minister should first of all be consulted. Accepting these conditions the Korean minister boarded the Omaha. As the American vessel passed through the cordons of a Chinese fleet which had been sent to intercept the Korean mission, the salutes fired from the cannon of the Chinese war-ships caused consternation 
among the members of the Korean party, who thought that the Chinese were there to capture them.

The picturesque party burst upon Washington in January, 1888. The Chinese minister there had already announced that he would introduce the Korean minister as vassal envoy, and insisted upon carrying out this announcement. But Dr. Allen, on behalf of the Korean minister, declined to accept such humiliating treatment, and insisted that the presentation of the Korean representative required no introduction from the Chinese Legation. At this juncture the American government showed no desire to exercise its influence in favor of the Korean envoy, but told him that the matter was one that had to be settled between the Chinese and Korean ministers. After much argument and counter argument Dr. Allen succeeded in presenting the Korean ministers without Chinese mediation, although he felt constrained to tender his resignation as adviser to the Korean Legation, thus assuming all the responsibility for the course pursued. His resignation, however, was not to exonerate the Korean minister, much less did it solve the question of whether the representative of the Korean ruler should at a foreign capital be treated as an envoy from an independent nation. The Chinese government, seeing an affront to its dignity in the manner in which the matter was settled in Washington, demanded explanation of the Seoul court for the conduct of the Korean minister. Not satisfied with the apologies offered, China further demanded that the minister be recalled and punished for having slighted the legation of the suzerain state. What could poor Korea do but tremble and obey the stern mandate of the Son of Heaven? The unhappy minister was ordered home to be disgraced in order to "save the 
face" of the Chinese, and the Korean Legation at Washington, though allowed to remain there, became less than nominal.

The inevitable inference from this episode is that America was far from whole-hearted in upholding Korean independence, and when she acquiesced in the high-handed measure which China adopted in recalling and humiliating the first Korean minister to Washington, she virtually recognized China's suzerain power over Korea, thus converting into a dead letter the first article of the treaty of 1882 . The American government had perceived, seventeen years before the Roosevelt administration did, that no high-sounding proclamations and solemn covenants could maintain the independence of a nation, which had neither determination nor ability to uphold itself. The withdrawal of the American Legation from Seoul in 1905 was merely an epilogue to the drama written as early as 1888 .

From I 888 to 1905 nothing noteworthy happened between America and Korea, excepting that during that period American enterprise gained a strong foothold in the peninsula. The American diplomat who figured most prominently in Korea during these seventeen years was Dr. Allen. The career which this diplomat carved out in the Far East is alike unique and remarkable. Having spent a year in China as a medical missionary, he went to Korea in the same capacity in 1884 , and within a short time thereafter he became a confidant and adviser for the Korean emperor. From I 885 to 1888 he was in the service of the Korean government, and it was during that period that he conducted the Korean mission to America. Shortly after his resignation as adviser to the Korean court Dr. Allen was appointed to be a 
secretary of the American Legation at Seoul, and was gradually promoted to minister plenipotentiary to Korea, which post he occupied when the American Legation was withdrawn in 1905. It is with a pardonable pride that Dr. Allen, looking back at his achievements in Korea, says :

"It was a somewhat unique position in which I found myself upon leaving Korea after twenty-one years' residence there, having to my credit the introduction of the following new departures, all of a useful nature:Protestant missions and Western medical science; modern mining on a colossal scale; steam railways; electric trolleys and water-works, all of which were left in a successful, going condition."

The circumstance, which enabled him to secure various franchises for his nationals during his service in the American Legation, was that he was the most familiar foreigner in the inner circles of the Korean court, where he had served as physician and adviser. The characteristic manner in which he obtained such privileges and concessions is recounted by Dr. Allen himself. On the morning of October, 1895, when a band of reckless Japanese assassinated the Korean queen, six of the frightened officials, all occupying the highest positions, took refuge in Dr. Allen's bedroom where Mrs. Allen dressed the wounds of those who were injured. They were kept as refugees at the American Legation until, upon the escape of the emperor to the Russian Legation, they were made the cabinet, with Dr. Allen's old friend, the former minister to Washington, as prime minister, upon his own recommendation. Appreciating this kind treatment extended by the American minister the Korean officials wished to return the compliment, and when Dr. 
Allen asked for a concession for a railway to connect Seoul and Chemulpo it was instantly granted.

During his incumbency as minister to Korea an extremely amusing story was widely circulated in America and Europe, which resulted in the American Legation being deluged with applications for positions as nurse, physician, lady's maid, governess, coachman, cook, dentist, and what not. The incident was trivial as it was comical, but a few words will be said as it affords an apt illustration of how the influence of the press is sometimes abused for the sheer purpose of satisfying the sensations of an unthinking public. The story referred to is that of "Emily Brown," who, the newspapers said, was the daughter of an American missionary and was married to the Korean emperor. The story was so cleverly and truthfully told, setting forth much detail as to the pedigree, acquaintances, age, and personal appearance of the woman, that even the thoughtful were led to believe that Emily Brown could not be altogether a fictitious character. So annoying became applications for positions from all sorts of Americans that Minister Allen was obliged to issue a circular declaring that the whole story was a hoax. But the newspapers would lend no ear to the correction, and continued to publish the story until the climax was reached when this mysterious Emily, upon the abdication of the emperor, was flung upon the world and went wandering about the country asking charity at the portals of the people who had not even been allowed to cast a glance at her.

But we must leave the fairy tale, and come back to the proper field of our study.

The final stage in America's diplomatic relations with Korea is soon reached. In November, 1905, Japan, hav- 
ing proven by the verdict of war her ability to rule the peninsula, obliged the Korean emperor to sign an agreement, granting her a protectorate over the country. Within a few days after this announcement the Roosevelt administration recognized the validity of Japan's claim, and withdrew the legation from Seoul. The Korean emperor, acting upon the advice of an American citizen in Seoul, had addressed a petition to President Roosevelt entreating him to rescue Korea. This American friend of the emperor was universally believed to be Mr. Homer B. Hulbert, who went to Korea as a missionary, but in later years quit the ministry to publish in Seoul a KoreanEnglish newspaper entitled the Korea Reviezu. It was also understood that the emperor's letter was written by Mr. Hulbert himself. I shall therefore note its contents as set forth by its author himself in his admirable book, "The Passing of Korea." The letter " cited the fact that Korea has heretofore received many tokens of good-will from the American government and people, that the American representatives have been sympathetic and helpful, and that American teachers of all kinds have done valuable work. He (the emperor) granted that the government had not been what it should have been, and that many mistakes had been committed, but he urged that whatever the Korean people might think of their government, they were passionately attached to the real Korea, to their nationality; that they had few things to be proud of, and that if their nationality and independence, which had been guaranteed by Japan, were swept away, there would be left no incentive for the people to advance. He acknowledged the need of Japanese supervision and declared that the advice of Japan had been and would be followed along all lines that looked towards 
the betterment of conditions in the peninsula. He intimated that the acts committed by the Japanese during the past year did not warrant the giving to Japan of complete control of Korea, for it would make Japanese residents all the more contemptuous of the private rights of Koreans. He urged that Japan would be doing herself an injustice, in breaking her promise to preserve the independence of Korea, for it would make other powers rightly suspicious of Japan's good faith elsewhere in the Far East. In conclusion he asked the President to bring to bear upon this question the same breadth of view and the same sympathy which had characterized his distinguished career in other fields; and if, after a careful investigation, the facts above enumerated and others that would come to light should seem to warrant him in so doing, he should use his friendly offices to prevent the disaster to Korea which seemed imminent."

The appeal arrived in Washington, it seems, before the withdrawal of the American Legation at Seoul was ordered, but the President declined to receive it until the severance of diplomatic relations between Korea and America became an accomplished fact. The letter was cleverly written, and it no doubt elicited a deep sympathy from the President, but his " breadth of view," which the letter extolled, did not warrant his yielding to mere sentimentalities and taking sides against Japan. If the Korean ruler and people had the desire and the determination to preserve their independence, they ought to have vindicated the fact during the thirty years when circumstances, so far as the outer world was concerned, were not unfavorable for such an attempt. Japan had extricated Korea from the clutches of the Chinese, reasserted her independence, and made repeated efforts to help her reform 
her internal conditions. The emperor in his letter to the President endeavored to make it appear that he had followed Japan's good advice, but Mr. Roosevelt knew better. So far from doing what he should have done, he had wasted the thirty long years without doing anything towards the improvement of the deplorable state of his country, allowing his court to remain a hotbed of plots and conspiracies, and the rendezvous of witches, fortunetellers, charlatans, adventurers, and what not. It was more pitiful than ridiculous that the Korean king, utterly oblivious to the precarious condition of his government, took upon himself the high-sounding title of emperor in 1897 , and in 1902 invited foreign ambassadors to be present at a grand anniversary that was to have been celebrated in honor of his forty years of "enlightened" rule over the "great empire." All this and more Mr. Roosevelt had been fully informed of, and it was but natural that the emperor's appeal should have failed to influence the President's views. If one reads Mr. Roosevelt's recent speech in Cairo, wherein he upheld British rule and declared the Egyptians unqualified to regain independence, one can thoroughly understand why he did not countenance the request of the Korean emperor. And as Mr. Roosevelt also told the Englishman that unless he maintains good order and continues to make good in Egypt, he must in honor withdraw from that country, so we are constrained to tell the Japanese that their occupation of Korea can be justified only by demonstrating their sincere wish for the welfare of the Korean people.

It is not my place to pass judgment upon the manner in which Mr. Roosevelt received the Korean emperor's letter; but when future historians, far removed from the excitement of the actual scene, shall look at the matter 
in clear perspective, they will agree that Mr. Roosevelt's act in this case was neither "contemptuous" nor " treacherous," as Mr. Hulbert thinks it was, but was based upon his broad view of humanity, which is on the whole salutary and unimpeachable. And, as a Japanese, I must add that the prompt recognition by the American government of Japan's claim in Korea, at a time when the Mikado's Empire needed most the moral support of Western powers, will always be remembered with gratitude by the Japanese, and unless those critics, who have their own axes to grind, conspire to misrepresent Japanese activities before the American public, the Korean question will provide no occasion for disturbing the traditional friendship between the two nations. 


\section{$\mathrm{X}$ \\ JAPANESE ENTERPRISE IN KOREA}

T $\mathrm{N}$ an age when diplomatic questions are discussed in conventional manner and often in super-polite 1 phrases, it is refreshing to note a frank, and even rude expression of views upon international relations. It is with this pleasing sensation that I read in Mr. Thomas F. Millard's "The New Far East" the following passage :

"I advance no claim that America is more disinterested than other nations. Her policy is based upon the belief that the 'open door' will be best for her interests, just as some other powers consider the sphere-of-influence doctrine as best calculated to advance theirs. All are purely selfish, in the sense that each nation is concerned most about its own advantage."

I would be the very last man to emulate Mr. Millard's method of dealing with the Far Eastern question, but the remarkable straightforwardness with which he expresses himself no one will hesitate to admire. However that may be, here I desire to emphasize the idea that the above-cited view of Mr. Millard's with regard to the American policy in the Far East is exactly what I want to apply to the Japanese case in Korea. However anxious some officially inspired writers may be to have us believe that Japan's war with Russia was a crusade whose incentive was purely disinterested and humane, no one 
will be so credulous as to be deceived by a pretense so transparent. As the economic interpretation of history has expounded, there can hardly be such a thing as altruistic war, and the war which the Sunrise Empire waged against the Muscovites is no exception to the general rule. True, Japan at first made it her avowed aim to uphold Korean independence, but that affords no indication of the disinterested nature of her purposes. The fact is that she believed her interests would be best served by maintaining the independence of Korea, if Korea was only capable of adopting such measures as were necessary to attain this end. It was therefore but natural that, when thirty years of consistent efforts to invigorate the effete nation convinced her of the futility of all such attempts, she should not hesitate to alter her fundamental policy and assume the control of Korean affairs in her own hands. It is as vain to claim that her championship of Korean independence sprang from any altruistic motive as it is unreasonable to impute bad faith to her when she receded from her first avowed principle. In either case she was actuated by the urgent necessity of protecting her own interests, and even safety, and it was only after her sincere hope of attaining that end by preserving Korean autonomy was utterly blighted that she was driven to adopt the only alternative of making herself the mistress of the situation.

It is in harmony with the above interpretation that since the establishment of her paramount authority over Korea, Japan has been busy promoting various enterprises of such nature as would benefit Korea as well as herself. Finding the national structure of Korea crumbling and tottering, she was confronted first of all with the task of preventing it from a total collapse. But the 
old material was of slight value in the work of renovation, and Japan had to bring along with her new material in order to infuse life and energy into the decaying nation. "The Japanese," says a prominent American journalist, " have taken the Hermit Kingdom by the neck, and are shaking its dry bones into action." The truth is that dry bones do not act, however vigorously you may shake them, and the Japanese found it imperative to employ new materials as well as new methods. The appointment of Japanese to various important positions in the Korean government before the annexation is one of many instances of this inevitable arrangement. In the various enterprises which Japan has launched in the country we find another example of similar nature. These enterprises, it must be admitted, have been meant not only to advance Japanese interests but to furnish a concrete example which will bring home to the Koreans the indisputable advantage of adopting modern civilization. Within the past half-decade Japan has placed at Korea's disposal all the fruits of a cycle of her own strenuous life, expending for that purpose 93,000,000 yen during the short period of three years (1906-I908), and yet it does not appear that any ordinary incentive will move the Koreans out of their indolent groove. What could Japan do but go ahead and adopt necessary measures at her own initiative, if she is to accomplish the Herculean task of regenerating a nation of ten million souls?

One of the most important Japanese enterprises in Korea is the construction of railways. Japanese railway enterprise in the peninsula dates back to 1898 , when a Japanese syndicate purchased from an American citizen the concession to build a railway connecting Seoul with 
the Chemulpo anchorage. The first railway ever built in Korea, the line was opened to traffic in October, I90I. In the same year when the Seoul-Chemulpo railway concession was granted, another concession on a much greater scale was obtained by another Japanese concern, with an authorized capital of 25,000,000 yen, and enjoying the Japanese government's guarantee of interest on the debentures issued by the company. This concession was that of constructing a railway of 268 miles between Seoul and Fusan, and the company was called the SeoulFusan Railway Company. Towards the end of 1903, when the relations with Russia became strained, the Japanese government granted the company an additional subsidy of 2,200,000 yen as well as a loan of $1,500,000$ yen without interest, charging the company to complete the construction as speedily as possible. Thus the line became available for transportation a few months before the outbreak of the war.

Another line of equal importance is that between Seoul and Wiju. The concession for this line was at first given to a French syndicate in 1896 , but owing to delay in commencing work, the concession was cancelled. Immediately after the outbreak of the war the Japanese army began building this railway as well as the Masampo line. The Seoul-Wiju line, 323 miles in length, was completed in March, 1906, and the Masampo line of twenty-five miles in May, 1905. All in all, railways in Korea open to traffic amount to $64 \mathrm{I}$ miles in length, with 104 locomotives, 158 passenger cars, and 955 freight cars.

Up to March 31, I907, 33, I94,910 yen was expended for the Seoul-Fusan line, 31,600, i Io yen for the SeoulWiju line, and 2,338,95 I yen for the Masampo line. In 
February, 1907, the Japanese Diet authorized the Railway Bureau of the Residency-General to establish a special account for the construction and improvement of railways in Korea. For this purpose a sum of $21,873,144$ $y e n$ was appropriated, to be expended in the four consecutive years as follows : $10,100,020$ yen in $1907 ; 7,257$,587 yen in $1908 ; 3,281,537$ yen in 1909; and $1,134,000$ yen in 1910. The plan was further elaborated in 1910, when the Diet assented to the additional appropriation of $36,820,000$ yen for the purpose of railway construction and improvement in Korea, the work to be spread over eleven years.

Almost as important as railway enterprise is the maintenance by the residency-general of a postal, telegraph and telephone service. The native means of communication were so imperfect and inefficient that in 1905 Japan found it necessary to take control of that branch of administration in her own hands. Since then Japan has expended $10,000,000$ yen for the installation and upkeep of post-offices, and telephone and telegraph lines. The enterprise, so far from profitable, has proved a great burden to the Japanese treasury, and there is yet no hope of recuperating the enormous losses she has been enduring. And yet Japan is bound to continue to improve these services if she means to be true to her promise to promote the welfare of the Korean people. A glance at the following table reveals the detail of expenditures and receipts relating to this enterprise :

$\begin{array}{llrr}\text { Year } & \text { Expenditures } & \text { Receipts } & \text { Deficits } \\ \text { 1905 } & 2,581,023 \text { yen } & 768,650 \text { yen } & 1,811,373 \text { yen } \\ \text { 1906 } & 2,296,078 \text { " } & 1,111,154 \text { " } & 1,184,924 \text { " } \\ 1907 & 2,183,664 \text { "6 } & 1,592,006 \text { " } & 591,658 \text { " } \\ 1908 & 2,303,704 \text { " } & 1,789,738 \text { " } & 513,966 \text { " }\end{array}$


In addition to ordinary postal business, the post-offices, which in 1908 numbered 272 , carry on the business of a savings bank. The amount of deposits by the end of 1908 reached $1,673,658$ yen. To encourage the habit of saving among the natives, pamphlets describing the method of the postal savings bank have been freely distributed through local authorities, schools and other organizations.

Of telegraph offices there were 172 in 1908 , and the number is being increased as necessity demands. At the end of the same year forty-seven cities and towns had telephone facilities, while such important cities as Seoul, Chemulpo, Ping-yang, Chin-nampo, and Yong-san are connected by long-distance lines.

Equally important is the banking business established in Korea by the Japanese. The pioneer Japanese bank in Korea was a branch of the Dai-ichi-ginko (First Bank) of Tokio. The branch was opened at Fusan in 1878 , but it was soon afterwards removed to Seoul. In I 884 the Korean government authorized the bank to issue "customs-house notes" in the treaty ports, the object being to facilitate the speedy payment of customs duties. In view of increasing commercial relations between Korea and Japan, and of the inadequacy of the monetary system in the peninsula, the Dai-ichi-ginko, with the approval of both the Seoul and the Tokio government, issued, in I90I, notes payable at sight, these notes being secured by reserves in accordance with special regulations. The bank also made monetary accommodation to the Imperial House as well as the government of Korea. Having already established such intimate relations with the financial world of the peninsula, it was natural that the Seoul government should in 1905 authorize the bank 
to act as the central bank of the country. Thus the Korean government recognized the notes issued by the bank as legal tender in all transactions, and authorized it to receive and disburse the national funds. In consideration of these and other privileges enjoyed by the bank, the institution was placed under the supervision of the Korean Minister of Finance, and required to observe the provisions of a Japanese imperial ordinance issued in March, 1905. This ordinance provides that the bank should provide special capital for its business transactions in Korea ; that it should hold, as a "conversion reserve," gold coins, gold and silver bullion, or convertible notes of the bank of Japan, equalling the total of the notes issued; that the amount of the silver bullion thus reserved should not exceed one-fourth of the entire reserve; that it should set aside each year at least one-twentieth of its annual profit, until such fund reached one-half of the capital invested by the bank for its Korean business; that the amount of notes issued by the bank should not exceed 10,000,000 yen, except in case economic considerations necessitated the issuance of larger amounts. So steadily did the reputation and popularity of the bank grow that by the end of December, 1907, notes issued by it exceeded the limit of $10,000,000$ yen by $2,805,300$ yen.

The Seoul branch of the Dai-ichi-ginko faithfully discharged its duties as the central bank of Korea. But being in its organization nowise different from an ordinary bank, it could not meet all the requirements essential to a central bank. Consequently the Japanese and Korean authorities agreed in July, 1909, to organize a new central bank independently of any Japanese bank. The Central Bank of Korea thus organized is a joint- 
stock company and is to exist for a period of fifty years. Its capital is $10,000,000$ yen, which is divided into 100,000 shares of 100 yen each. The share certificates bear the name of the purchaser, and can be held by Koreans and Japanese only.

It will be seen that the Central Bank is a JapaneseKorean enterprise. After its organization is completed the Dai-ichi-ginko will still maintain its branch office in Seoul, and carry on ordinary banking business. Besides the Dai-ichi-ginko, four Japanese banks, with an aggregate capital of $67,000,000$ yen, maintain branches in Korea, devoting an additional capital of $13,000,000$ yen to their business in Korea, whereas there are only three ordinary banks maintained by Koreans, whose aggregate capital does not exceed 950,000 yen.

Another Japanese-Korean enterprise is the organization of a joint-stock company with the object of promoting agriculture in the peninsula. This company came into existence in August, I908, under the name of the Oriental Development Company. The scope of the business to be engaged in by the company is defined by its regulations as follows :

I. Sale, purchase, renting and leasing of lands requiring development.

2. Undertakings connected with the cultivation of the soil.

3. Construction, sale, purchase and renting of buildings necessary for the cultivation of the land.

4. Assembling and distributing Japanese and Korean settlers necessary for cultivation of the land.

5. Supplying settlers and farmers with articles necessary for agriculture, and the distribution of articles produced or acquired by them. 
6. Advancing money to Japanese and Korean settlers to defray expenses of settling.

7. Making loans to settlers and farmers on the mortgage of immovable property, or on the security of articles produced or acquired by them.

In addition, the company may engage in fishery or other undertakings where such undertakings are deemed necessary as an accessory to the main business. Indeed the fishery industry will become one of the important undertakings of the company, as the natives have neglected to take advantage of marine resources in which the country is rich. While Japan, with a coast line of 8,000 nautical miles, annually gathers marine products to the extent of $100,000,000$ yen, Korea, whose coast line extends over 6,000 nautical miles, obtains only $7,000,000$ yen by fishery. The primary object of the company, however, is the exploitation of land, by agriculture, forestry, horticulture and cattle breeding. The urgent necessity of such an undertaking can be understood when it is remarked that nine-tenths of the whole peninsula is left as waste land or denuded mountains. The Koreans, though essentially an agricultural people, are as slow to adopt modern productive methods of farming as they are indifferent to the impoverished condition of their land. The agricultural industry of the country will never rise above the plane where it rests at present, unless a wellorganized company shall initiate advanced methods with adequate capital and experience.

The Oriental Development Company has a capital of $10,000,000 y e n$, which is divided into 200,000 shares to be subscribed for exclusively by Japanese and Koreans. The Korean government subscribed for 60,000 shares, having a face value of $3,000,000$ yen, in the form of 5,700 
cho (about 14,200 acres) of paddy fields and another 5,700 cho of upland fields. Of the remaining 140,000 shares, 8,400 were set apart as preferential for the Imperial Households of Japan and Korea ; I,000 were taken by the directors of the company, thus leaving I 30,600 shares for general subscription by the public. The prospects of the company were so bright that the public subscriptions in Korea and Japan reached 4,665,442 shares, or thirty-six times the amount floated. Of the entire 200,000 shares, 136,138 are owned by Japanese, and the remaining 63,862 by Koreans. The Japanese government guarantees the reimbursement of debentures issued by the company up to $20,000,000$ yen. Not only this, but the same government grants the company an annual subsidy of 300,000 yen for the first eight years of the company's existence, when little profit is expected from its various undertakings.

Of enterprises, not semi-governmental but purely private, we must first of all mention the undertakings of the Japanese-Korean Gas and Electric Company, which succeeded the American-Korean Electric Company founded by the firm of Collbran and Bostwick. The newly organized Japanese company proposes to double the electric trolley track in Seoul, which was originally laid by the American firm. It will also enlarge the power house, and put improved cars on the road, fifty new cars having already been ordered from America. New gas mains have been laid by the company, and within a few weeks all the principal streets in Seoul will be illuminated with gas light. The American-Korean Electric Company, when handing over its business to the new Japanese company, secured from its successor a promise that no change would be made in the personnel of the original 
company, except in the case of highly-paid Americans. In deference to this pledge the Japanese company is obliged to maintain a staff which, considering the present dimensions of the business conducted, seems too large.

But the true extent of Japanese enterprise in Korea cannot be measured merely by those undertakings which the Japanese government or corporations have launched in the peninsula. For not less important than these are enterprises of private individuals in agriculture, in industry, and in commerce. Small in scale, the shops and factories and farms owned by these individuals may not attract much attention, yet these constitute an important factor in the assimilation of the Koreans with the Japanese, and vice versa. They come into close contact with their native neighbors; they patronize and are patronized by the Koreans in mercantile business ; they disseminate their own ideas and experiences among the natives and in turn benefit themselves by absorbing the ideas and experiences of the latter. In such and many another manner they will in time become the woof and warp of Korean institutions. That, indeed, is the only process by which a nation can establish a firm hold upon another, which it wishes to affiliate with itself not only in form but in reality.

At the end of 1908 there were in Korea 126,168 Japanese, showing an increase of 28,167 over the figures for 1907. As the number of the Korean population is estimated at 9,78I,000, it works out that to every 1,000 Koreans there were ten Japanese in 1907, and twelve in 1908. Classifying by occupation the Japanese population in Korea at the end of 1908 , we obtain the following table: 


\section{Occupation}

Officials and teachers
Number of Population

16,502

$$
\begin{array}{r}
379 \\
278 \\
108 \\
1,020 \\
146 \\
4,887 \\
47,398 \\
2,956 \\
11,763 \\
15,237 \\
16,815 \\
4,424
\end{array}
$$

4,253

It will be seen that the number of Japanese farmers was comparatively small-a phenomenon which is by no means desirable from the view-point of solidifying the Japanese position in Korea. The above statistics were compiled from figures obtainable before the Oriental Development Company began its work for the encouragement of Japanese and Korean agricultural settlers. With this influential company now active in the field, it may be reasonably hoped that Korea will soon see a large number of Japanese farmers reclaiming her fallow lands, planting trees upon denuded plains and mountains, and what is most important, introducing agricultural methods superior to those followed by the natives. At the end of June, 1908, there were 8,474 Japanese landowners, whose holdings aggregated 228,090,529 tsubo (I 88,504 acres) valued at $\mathrm{I} 35,032,353 \mathrm{yen}$; but how much of this total area was agricultural land we are unable to ascertain. Buildings with the estimated value of $12,088,458$ yen were owned by 7,580 Japanese.

In conclusion it seems not amiss to note what Japan has, up to the annexation of Korea, expended for her 
Korean enterprise. The following table shows the summary of Japan's Korean budget for the three years following the establishment of the residency-general :

Names of offices, etc.

Expenses for inaugurating Residency-General . . . Residency-General, lo c a 1 Residencies, Court of Appeal $\cdot$ Construction and repair of office buildings . . . . .

Educational aid for Japanese settlements

Subsidies to fishery

Agricultural and industrial model farm

Expenses for preventing epidemic diseases . ....

Forestry undertakings station Subsidy to Oriental Development Company . . . .

Patents Bureau . . . .

Railway Bureau . . . . .

Communications Bureau . Army and Navy .....

Loan to Korean government

Total. ......

\section{Expenditure} 1908

Expenditure
1907

Expenditure 1906

I 14,015

$\begin{array}{rr}\text { I, 185,916 } & 1,468,872 \\ 287,365 & 226,690 \\ & \\ 30,000 & 20,000 \\ 20,000 & 20,000\end{array}$

$1,223,117$ 507,825

$14,93^{\circ}$ 167,894

$$
300,000 \quad 300,000
$$

300,000

43,914

$7,661,533$

$2,276,695$

I $5,229,116$

$5,259,580$

32,594, I 19

$$
\begin{array}{r}
12,098,046 \\
2,183,664 \\
10,720,967 \\
1,769,503 \\
\hline 28,907,742
\end{array}
$$

$2,117,025$

$2,296,078$

I 4,87 I, 528

Of the offices here enumerated the Railway and the Communications Bureau are the only places which earn an income. Yet the earnings of these bureaus have been much less than the amount of expenditures they have entailed, and no one can yet venture to foretell how soon Japan will be in a position to balance cost and gain. As I have already said, the Communications Bureau received $1,180,738$ yen in 1908, but the expenditure for that year amounted to 2,276,695 yen. Discrepancy between income and expenditure is even more marked in the case of the Railway Bureau, whose balance-sheets showed a 
deficit of 94,377 yen in 1907, and of 211,687 yen in 1908 . How the annexation, instead of lightening the financial burden, increased it to a great extent, will be described in the proper place.

We have been told that Japan's method in Korea is little better than the method followed by the Spanish conquerors of yore who sacked every country upon which they set their feet. To be sure, the facts described in this and other chapters do not warrant such an opinion. Blind indeed the Japanese must be if they, with all the history of colonial successes and failures of other nations before them, fail to perceive that tyranny, be it never so well-meant, is always bounded on all sides by the black horizon of revenge and rebellion. Their past activities certainly do not support any theory which credits them with so little a gift of foresight. 


\section{$\mathrm{XI}$}

\section{WHAT JAPAN HAS DONE FOR KOREA}

WE reform measures to be described in this chapter were all inaugurated before the annexation of Korea to Japan. These measures, except in a few cases, will not be affected by the change of the political status of the peninsula. The Korean emperor is divested of sovereignty, but Japan will treat him with the same respect and consideration as hitherto; the government of Korea exists no more, but the progressive policy which it inaugurated at the instance of the residency-general will be maintained. Furthermore, a fairly good knowledge of the state of Korean administration before the annexation is essential to a clear understanding of the situation which necessitated the obliteration of Korean independence. It is with this fact in view that the present chapter is prepared.

It is rather difficult to offer a satisfactory explanation for my treating "What Japan has done for Korea" apart from "Japanese Enterprise in Korea." There is no clear line of demarcation between the two. Both are Japanese enterprises, and both for the welfare of Korea. And the welfare of Korea was, even before the annexation, likewise the welfare of Japan, and vice versa, for the two countries were one in reality, if not in name. When, therefore, we speak of what Japan has done for Korea we also speak of what she has done for herself. But the various enterprises, which I have described in the foregoing chapter, were inaugurated either in Japan's own 
name or in the name of both Japan and Korea, while in the case of the undertakings which I shall presently describe, it was the Korean government which was responsible for them, nominally at all events, although these, too, were due to the initiative of the Japanese. In the former case Japan's interest was direct and substantial, in the latter it was moral rather than material, indirect rather than direct. For this reason I group some Japanese enterprises in Korea in one category, and others in another.

Let us begin with the Imperial Court. Under the old régime there was no distinction between the court and the government, and a host of sorcerers, fortune-tellers, mountebanks, and what not, who infested the palace, had as much influence in the administration of government as did the ministers of state. Taxes were collected both by the court and the government, each acting independently of the other. One day personal agents of the emperor would go out to a certain province and levy money in the name of the Imperial Household; the next day representatives of the government would appear in the same district and extort what they could from the people whose purses had already been emptied the previous day. The emperor, cheated out of his money by his designing favorites, contracted debts right and left, while the princes were not slow in emulating him. The different offices of the government likewise contracted loans without consulting each other, all in a most arbitrary manner. Not a semblance of system was to be seen in the management of financial or other affairs of court and government.

When, therefore, the residency-general assumed its duties, a thoroughgoing cleansing of the court and the 
government seemed of the first importance. The first measure adopted was the strict differentiation of the affairs of the court from those of the state. With the consent of the emperor the residency-general began, in 1906, placing constables at each gate of the palace in order to keep off persons of questionable character. At the same time the "Palace Precincts Ordinance" was promulgated, restricting the issuance of passes to persons known to have legitimate business with the court. This naturally caused the wrath of both Koreans and foreigners whose business was to prey upon the Imperial Household, but the Japanese authorities knew that the path of a reformer was not always strewn with roses. The above-mentioned preliminary steps towards the purification of the palace were followed in November, 1907, by a more vital measure entailing the dismissal of 4,1 26 court officials and employees and 222 court ladies. All the dismissed officials and ladies were given a pension, the sum paid for that purpose during 1908 being 270,820 yen.

Simultaneously with these measures, the residencygeneral took steps towards the settlement of debts incurred by the emperor and his relatives and officials. Thus in April, 1908, a law was promulgated, which, among other things, invalidated those claims which were not presented to the Imperial Household within three years from the date of promised reimbursement. It also -provided that no loan incurred by the Imperial Household prior to the enforcement of this law would be recognized, unless such loans were submitted before September 30, 1908. The claims duly submitted to the Imperial Household in accordance with this law amounted to $\mathbf{1}, 643,000$ yen, which has since been reimbursed under the supervision of the residency-general. 
Meanwhile, the residency-general took pains that everything should be provided for the comfort and dignity of the emperor. In Seoul one is struck with the decaying state of public buildings, from the walls around the city to the innermost precincts of the imperial palace. Deploring this condition, the residency-general, in 1908 , advised the Korean government to appropriate 300,000 $y e n$ for the repair and extension of the palace then occupied by the emperor, and an additional sum of 393,000 yen to be expended for the installation of an electric lighting plant and a telephone service for the palace; for the purchase of modern carriages to replace the uncouth palanquins; for the laying of an extensive drive road within the court grounds; for the establishment of an art museum, and zoölogical and botanical gardens to be maintained by the Imperial Household for the benefit of the public.

Now we come to the consideration of measures adopted to put the Korean administration upon a basis of efficiency. In the first place, the various departments of the central government were thoroughly reorganized, in some cases by amalgamating several offices, in others by abolishing those that were superfluous, or by creating new ones. At the same time the method of administrative business was readjusted along modern lines. The next important step was the prohibition of the sale of offices by high officials. To put an end to indiscreet appointment and arbitrary dismissal of officials, the residency-general, by the agreement of July 24, 1907, secured the right to be consulted by the Korean government upon all matters concerning the appointment and dismissal of high officials of the Korean government. Meanwhile, regulations were promulgated defining the qualifications necessary for candidates for various official positions. 
One of the chief causes of the corruption of Korean officialdom was the inadequacy of salaries paid to officials. Their regular stipends were hardly enough to meet even the sordid needs of life, and it was but natural that their recipients should resort to trickery to supplement their legitimate income. To remedy this deplorable condition it was necessary to increase the salaries of all officials from the highest to the lowest. A glance at the following tables, comparing the new schedule of salaries with the old, reveals how radical was the change introduced.

\section{TABLE OF SALARIES FOR THE SHINNIN AND CHOKUNIN RANKS}

\begin{tabular}{lc|cccr}
\multicolumn{2}{c|}{ Shinnin rank } & \multicolumn{4}{c}{ Chokunin rank } \\
Premier & $\begin{array}{c}\text { Ministers } \\
\text { of State }\end{array}$ & 1st grade & 2d grade & \multicolumn{2}{c}{ 3d grade } \\
New rates, 7,000 & 6,000 & 2,200 & 2,000 & 1,800 & 1,600 \\
Old rates, 2,500 & 2,000 & 1,500 & 1,250 & 1,100 & 1,000
\end{tabular}

II. TABLE OF SALARIES FOR THE SONIN RANK

\begin{tabular}{lcc} 
& \multicolumn{2}{c}{ Ist grade } \\
& Ist class & $2 \mathrm{~d}$ class \\
New rates, & $\mathbf{1}, 400$ & $\mathbf{1}, 200$ \\
Old rates, & 800 & 700 \\
& \multicolumn{3}{c}{3 d grade } \\
& Ist class & 2 d class \\
New rates, & 800 & 700 \\
Old rates, & 400 & 300
\end{tabular}

$$
\begin{array}{cc}
\text { Ist class } & 2 d \text { class } \\
1,000 & 900 \\
600 & 400 \\
\multicolumn{3}{c}{4 \text { th }} & \text { grade } \\
\text { Ist class } & 2 d \text { class } \\
600 & 500
\end{array}
$$

III. TABLE OF SALARIES FOR THE HANNIN RANK

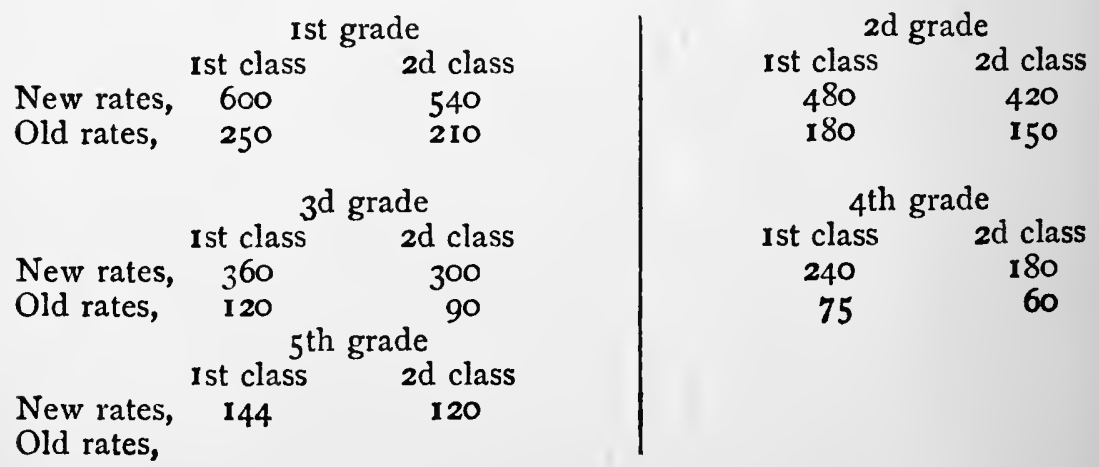


With all these measures put into operation, it was nevertheless no easy task to divest Korean officialdom of pernicious practices, unless it was guided and superintended by officials whose conduct would afford an object lesson in efficiency and probity. It was with this point in view that the residency-general, in pursuance of the agreement of July, 1907, recommended to the Korean government the appointment of Japanese subjects to various important offices. At the end of 1908 there were 2,090 Japanese officials thus appointed as against 3,02 I Korean officials. The distribution of these Japanese among various departments, and their proportion to Korean officials are shown in the following table:

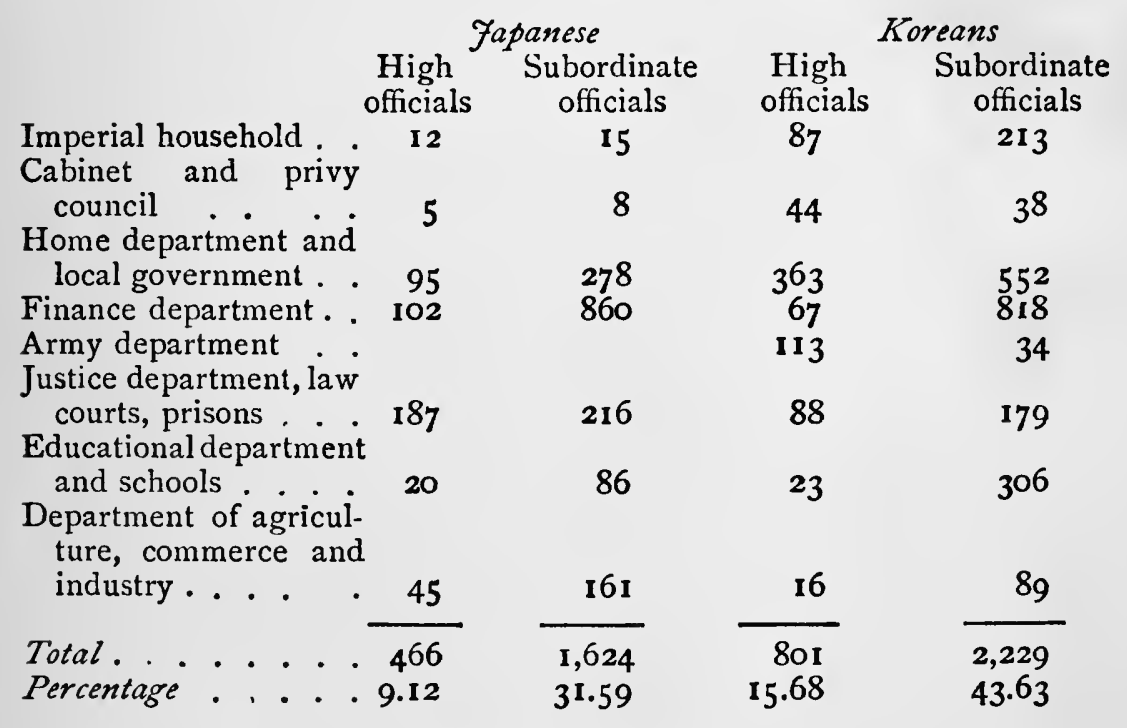

It will be noticed that in the Cabinet, and the Departments of the Imperial Household, Home Affairs and Education, Japanese high officials were less in number than Korean officials of the corresponding rank. But in the Departments of Finance, Justice, and Agriculture, 
Commerce and Industry, the number of Japanese exceeded Koreans-an arrangement necessitated by the fact that much technical knowledge is needed in these departments.

So much for the reform achieved within the court and the government. Next to be considered are those undertakings calculated to bestow material benefit upon the public. These include sanitary measures, the extension of public education and industrial training, construction of highways, subsidizing the agricultural and industrial banks, and the construction of various public buildings. To carry out these public works Japan, in I907, loaned Korea 5,000,000 yen with an interest of six and onehalf per cent. per annum, and in 1908 an additional sum of $17,963,920$ yen on easier terms. The following table shows the principal items among which these funds were apportioned :

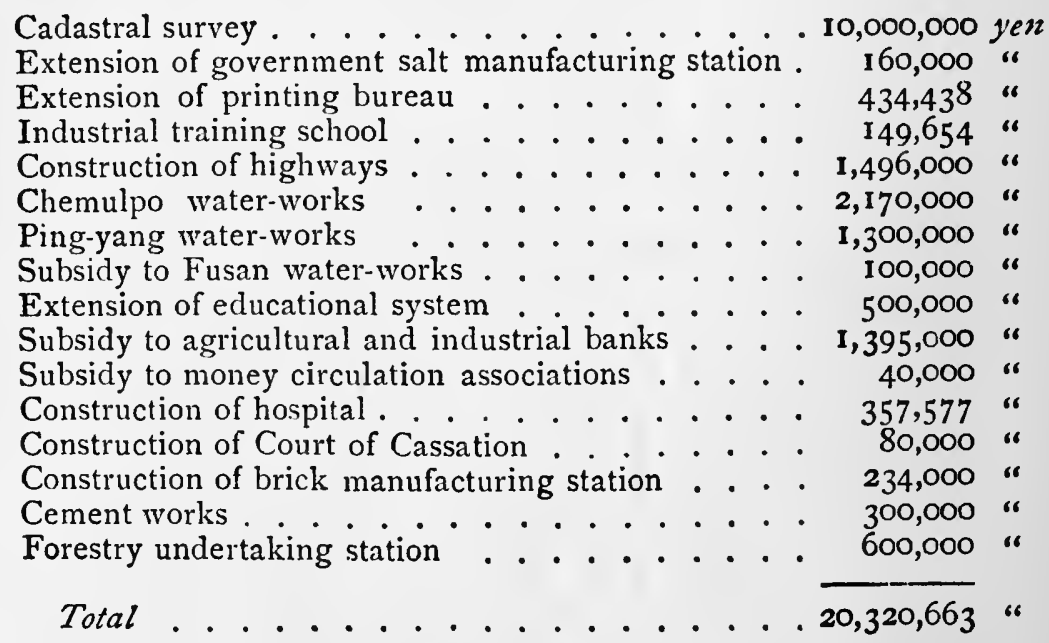

Of these items the first, which claims the lion's share of the public-undertakings fund, requires special explanation. 
In Korea land tax is levied on the unit of "kyel," which is divided into six grades according to the fertility of the soil, the facilities of irrigation, etc. The first grade of the kyel represents 100 man-loads of unhulled rice, each man-load being composed of ten sheaves; the second represents eighty-five man-loads, or fifteen man-loads less than the first grade; and so on to the sixth grade which represents twenty-five man-loads. Now the present number of kyels is based upon the investigation and surveys made five centuries ago, when there were 1,455 ,492 kyels. To maintain the accuracy of assessment the number of kyels was to be revised from time to time, so far as the law went. But as administrative corruption grew with the years, local magistrates neglected to register new kyels, for the obvious purpose of peculation. This, coupled with the fact that a large number of kyels were exempted from taxation on account of ravages wrought by natural calamities, resulted in the gradual decrease of kyels, until by 1902 , the total number was reduced to 988,147 . The effect of this anomalous condition upon the revenue of the central government has been anything but desirable. To make the matter still worse, the Korean method of measuring land is even more rudimentary than the method of determining the unit of assessment. In measuring rice fields the unit adopted is the area that requires one to of seeds; in the case of ordinary land the unit is the area that can be ploughed by one man and one ox in one day.

If this antiquated method is replaced by a scientific method of surveying and assessment, there is no doubt but that the national revenue of the country will be greatly increased without raising the present rate of taxation, putting a stop to evasion and delinquency as well 
as official embezzlement. This is the reason why cadastral surveys are considered of the first importance in the financial rehabilitation of Korea. A coterie of Japanese civil engineers were invited to Seoul to train Korean students in the principles and practice of land surveying, and the field work has already been commenced.

In the foregoing chapter it has been noted that the semi-official Oriental Development Company has for its main purpose the encouragement of agriculture and kindred industries in Korea. Another potent factor in the promotion of agriculture is the establishment of agricultural and industrial banks, and the subsidizing of the socalled "local monetary circulation associations." While the Oriental Development Company deals with both Koreans and Japanese, these institutions are exclusively for the benefit of Koreans. The agricultural and industrial banks are to advance funds for the cultivation, drainage and improvement of land; the construction and improvement of roads; forestry undertakings; the purchase of seeds, plants, manure, or other materials for farming and manufacturing; the purchase of agricultural and industrial implements; the construction of buildings for agricultural or manufacturing purposes; and various other purposes of a similar nature. At the end of 1907 there were nine agricultural and industrial banks with seventeen branches and agencies, and their aggregate capital was $12,000,000$ yen. While these banks are essentially private organizations, the Korean government rendered them a substantial assistance by subscribing for their shares to the extent of 335,960 yen, and by loaning a sum of $\mathrm{I}, 058,680$ yen without interest. Where agricultural and industrial banks have not yet come into existence, the deficiency has been supplied by the organiza- 
tion of "Local Monetary Circulation Associations," facilitating the circulation of money among small farmers, each association being subsidized by the government to the extent of 10,000 yen. At the end of 1908 there were forty-eight of such associations, with 15,059 members and a capital of 480,000 yen.

Along with the establishment of banking facilities for farmers, various other measures were adopted for the advancement of agriculture. Korea was once Japan's teacher in sericulture, but now the progressive islanders are returning courtesy by imparting to the now backward peninsular people the improved method of that industry. At the instance of the residency-general the Women's Sericulture Training Association was organized at Yong-san, which has been followed by many another in various parts of the country. To each of these associations the Korean government granted an annual subsidy, gave silkworm eggs of the best quality, as well as mulberry trees imported from Japan, and in some instances furnished silk spinning machines or wheels. The government also despatched experts in sericulture, both Japanese and Korean, to different parts of the country to give the people instruction in the industry.

But the encouragement afforded to sericulture is only one of the many instances of the method with which the economic resources of Korea are being developed and exploited under the new régime. Five model farms, or agricultural experimental stations, have been established, one each at Su-won, Mokpo, Kun-san, Ping-yang and Tai-ku; a school of agriculture and forestry has been opened in connection with the model farm at Su-won; effective measures have been adopted for repairing the 
old irrigation ponds, which though originally serviceable became practically useless through ages of neglect; horticultural stations, nursery gardens, and a cotton plantation station have been inaugurated in various sections of the country, all by the initiative and under the auspices of the government.

Nor did the government confine its activities to agriculture: in the field of industry it did commendable work. The Department of Agriculture, Commerce and Industry instructed the provincial governors to investigate the industrial conditions in their respective jurisdictions, and to report the most promising industries which might be encouraged in the interest of the country. The result was the granting of subsidies, though on a small scale, to weaving and matting industries, paper manufacture, and bamboo works. But all industries in Korea are in the infant stage, and await improvement at the hands of the rising generation trained in modern sciences and arts. To meet this urgent necessity the Korean government was persuaded to establish an industrial training school in Seoul, with courses in dyeing and weaving, keramics, metal work, applied chemistry, and civil engineering. Meanwhile, a commercial school was established in Seoul with a fund of 200,000 yen donated by Mr. K. Okura, a wealthy Japanese merchant, who had already established two commercial schools in his native country.

In travelling through Korea one is struck with the denuded condition of its mountains and hills, and one wonders if it was one of the whims of nature that omitted to adorn them with trees. Yet there is evidence that in ancient times this grim, naked country was clad with vegetation. What was it, then, that converted Korea 
into a treeless country? The only plausible answer to this question seems to be that the natives felled timber in a most arbitrary manner, and when the mountains and hills and plains were divested of trees, never thought of setting young plants, thinking, perhaps, that forests, like Aladdin's palace, would spring from nothing. The tyranny of the Korean ruler also had something to do with the annihilation of forests. It is within the ken of history that people in different localities set fire to forests merely to avoid the imposition of whimsical sovereigns who would command their subjects to bring timber to the capital to furnish material for their new palaces. In an age when there was no iron road and in a country where even the beasts of burden were but sparingly utilized, it is beyond our imagination what enormous labor and what appalling suffering it must entail to haul huge timber, often hundreds of miles, over rough trails degenerating now and again into ravines and ditches. Small wonder that the abused people should have reduced their forests to ashes rather than be so imposed upon by extravagant rulers.

However that may have been, the residency-general found it an urgent necessity to reforest the denuded mountains and hills which brought about calamities such as flood and landslides so common in all treeless countries. Thus the Japanese authorities caused the Korean government in 1907 to establish model forests in the mountains near Seoul, Tai-ku and Ping-yang, as well as three extensive nurseries in the vicinity of Ping-yang, Tai-ku and Su-won. A bureau of forestry was created in the Department of Agriculture, Commerce and Industry, and a school of forestry and agriculture was established at Su-won. The model forestry stations are all equipped 
with a staff of experts and clerks, and are intrusted with the task of afforesting the mountains, plains, and moors belonging to the state. The model forests already established comprise 83,300 acres and will in time contain I 7,889,000 trees. To supply them with young trees, the nursery gardens at Su-won, Ping-yang and Tai-ku, up to the end of 1908, raised 3,531,846 plants.

Next we must consider sanitary measures, which in a country like Korea, frequented by all sorts of epidemic diseases, are of the utmost importance. In January, 1908, a sanitary bureau was created in the Department of Home Affairs, and was intrusted with the administration of sanitary affairs of the country. Measures have been adopted to combat cholera, typhoid fever, smallpox, dysentery, diphtheria and scarlet fever, and the effect has already become perceptible in spite of native prejudice against such measures. The characteristic attitude of Koreans towards the stern requirements of modern civilization is seen in the idea they entertain of the hospital for epidemic diseases. Should a Korean patient die in such a hospital whither he was taken by order of the government on account of cholera or diphtheria he contracted, the picturesque Koreans believe that the poor man was buried before he breathed his last. This is how the Koreans got the notion that the Japanese, like the tyrants of old, burn patients or bury them alive.

Before the advent of the new régime Korea had no adequately equipped hospital. Missionary hospitals there were, and also a few small hospitals maintained by the Korean government or various Japanese settlements; but these were all imperfect in more respects than one. In 1906 the Korean government, at the advice of the residency-general, decided to inaugurate a large hospital 
by amalgamating the hospitals then maintained by the government. For this purpose 357,577 yen was allotted. The hospital thus established was called the Taihan (or Great Korea) Hospital, and was under the control of the Home Department. Its medical faculty was composed of a president, eight Japanese and two Korean doctors, three Japanese and five Korean assistants, four Japanese pharmacists and ten Japanese nurses.

As a corollary to the establishment of the Taihan Hospital a medical school was inaugurated, which became the successor to the old Seoul Medical School maintained by the Educational Department. The new institution is much larger in scope and more complete in equipment than its predecessor, and is designed to train Koreans not only as physicians and pharmacists, but also as midwives and nurses.

In the execution of sanitary measures the supply of pure water is of the first importance. Especially is this true in a country where impure water has been the main cause of epidemic diseases which have swept away thousands and even tens of thousands of human lives year after year. And yet the question of water supply had never attracted the serious attention of the Korean authorities or people, until the Japanese municipal council in Seoul held, in January, 1904, a meeting to discuss the matter, which resulted in a decision to build a reservoir near Seoul at a cost of 100,000 yen for the purpose of supplying the Japanese settlement with pure water. The resolution was not carried out, owing to the protest of Messrs. Collbran and Bostwick, an American firm, which claimed the exclusive privilege of constructing waterworks in Seoul. Of the enterprise of this American firm I shall have the occasion to speak at length in a follow- 
ing chapter; here we are concerned with the work of the Korean government and the residency-general. In 1906, the residency-general advised the Seoul government to install water-works in the principal towns. As the consequence a bureau of water-works was organized, and the construction of water-works at Chemulpo and Ping-yang was commenced, with funds amounting to 2,170,000 yen and 1,300,000 yen, respectively. At the same time a subsidy of 350,000 yen was granted to the Fusan waterworks undertaken by the Japanese settlement there, while a loan of 150,000 yen was made in favor of a similar undertaking by the Japanese settlement municipality in Mokpo. All these works were completed during 1910.

Last to be considered is educational reform. Immediately after the Chino-Japanese war the Korean government made a feint of following Japan's urgent advice for educational reform, by issuing several laws and ordinances relating to primary, middle, normal and technical schools, but these plausibly commendable laws were never carried into effect. True, several schools were established in Seoul and a few other principal towns, but these did little more than the teaching of Chinese ideographs and caligraphy. The original native school system comprises the Clu-pung, the Han-gyo, and the Son-gyun-kaon. The Clu-pung is a school, if school it may be called, maintained by a village literateur who teaches the writing and reading of Chinese characters; in the Han-gyo, where the image of Confucius is worshipped, more advanced lessons in Chinese literature are offered; the Son-gyun-kaon, the highest seat of learning, is in Seoul, and is devoted to the study of the Chinese classics.

It will be seen that the uriginal system of education was utterly out of touch with the spirit of the times. 
Consequently the residency-general prevailed upon the Korean government, in March, 1906, to appropriate for educational reform 500,000 yen. Of this sum, 350,000 yen was allotted for improving and establishing common schools, high schools, and foreign language schools. Thus up to the end of 1908, fifty-nine common schools were established in accord with modern principles of pedagogy. In the common schools compulsory attendance is not in vogue, as the present standard of living in Korea does not warrant the adoption of such a system; but to attract children to the schools both tuition and text-books are given gratuitously. Along with the inauguration of common schools, a high school, a foreign language school, and a normal school were established in Seoul, while the time-honored Son-gyun-kaon was improved by adding to its curriculum elementary law and economics, mathematics, history, geography, the Japanese language and the Korean classics. At the same time, the authorities have not neglected the education of girls. In Korea, as in China, women are relegated to a shady hemisphere, with the result that the education of girls has been regarded as something utterly useless. While recognizing the necessity of educating girls, the authorities have not deemed it wise to upset the established moral conceptions of the people, and in consequence girls are taught separately from boys in the new common schools, and a high school exclusively for girls has been established in Seoul. 


\section{XII}

\section{JUDICIAL REFORM AND EXTERRITORIALITY}

IN KOREA

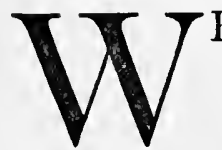

E have already discussed what Japan has done for the amelioration of the internal conditions in Korea, but the reform in the field of judicial administration deserves a separate chapter. So important is the inauguration of a modern system of law courts in Korea that an appreciative writer in the Outlook fitly declares that if Japan can succeed in this one respect "she will have more than earned her right to its occupation." The abolition of exterritoriality, as a consequence of the annexation of Korea by Japan, adds much interest and importance to the question of judicial reform.

This latter phase of the question has been discussed by American and European critics, some favoring the abolition of exterritoriality, but not a few decidedly objecting to such a course. One of those American writers whose business seems to be wholesale condemnation of the Japanese, finds in exterritoriality one of the "bulwarks behind which advocates of the 'open door' may still make a stand." Whether Japan has deviated from the principle of the "open door" is a question which I have already discussed in previous chapters, and which I shall recur to in the proper place. What I desire to direct the attention of the reader to here is the following clause in the American-Korean treaty of May, I882:

"It is, however, mutually agreed between the high 
contracting powers that whenever the king of Chosen (Korea) shall have so modified and reformed the statutes and judicial procedure of his kingdom that, in the judgment of the United States, they conform to the laws and courts in the United States, the right of extra-territorial jurisdiction of the United States shall be abandoned, and thereafter the United States citizens, when within the limits of Chosen, shall be subject to the jurisdiction of the native authorities."

Other Western powers followed the suit of the United States, and inserted a similar provision in their treaties with Korea. In the face of this tacit provision, it would have been difficult for the Western nations to maintain the privilege of consular jurisdiction in Korea, even if Korea had not been annexed by Japan, for the Japanese installed in the peninsula a system of law courts that was calculated to sweep away the corruption, iniquity, and general travesty of justice that had for ages characterized the course of civil polity in the country.

It goes without saying that before the advent of the new régime Korea possessed neither law nor tribunal efficient to protect the property and safety of the people. Then extortion, blackmail, embezzlement and what not were practiced almost with impunity, the officials themselves having often been hand-in-glove with the culprits. One of the common methods of extortion in those days was that of accusing a man of an offense and demanding pecuniary payment. As no less an authority than Mr. H. B. Hulbert says, this practice was so common that it was frequently anticipated, and regular sums were paid over for the privilege of not being lied about, just as bands of robbers are subsidized in some countries to secure immunity from sudden attack. If a man of the upper class 
had any ill-feeling against a man of the inferior class, he would simply ask the authorities to detain the latter in jail for several days, administering severe beating once a day. In most cases this was done without any investigation as to whether or not the accused man was really to blame. This abominable practice, coupled with offcial peculation and extortion, has made the Koreans the most suspicious, intriguing people.

It was not only after the inauguration of Japanese rule that Japan attempted to reform the judicial system in Korea. In the wake of the Chino-Japanese war Japan urged upon Korea the necessity of doing away with the pernicious method of meting out justice. As the consequence a code for the constitution of law courts was promulgated on March 25, 1895. It provided for the establishment of a special court to deal with crimes committed by members of the imperial family, a court of cassation, circuit courts, local courts, and "treaty-port courts," the last of which was to determine cases of an international nature. A law school was to be founded for the purpose of training judges, public procurators, and clerks. But this apparently commendable plan was not carried out, excepting the establishment of the Court of Cassation and the Seoul Local Court, with the result that the provincial governors, prefects, superintendents of treaty ports, and district magistrates were allowed as before to combine in their respective offices the functions of executive officials and those of judges. Civil cases were usually determined according to the amount of bribe offered by plaintiff or defendant, while criminal cases were judged according to the whims of the officials. There was no barrister to defend the accused; a witness was in many cases found to be a particeps criminis; evidence desired by the magis- 
trate was extorted by brutal methods of torture. The result was a universal miscarriage of justice. Even in the Court of Cassation and the Seoul Local Court, considered comparatively free from corruption, judgments delivered were often iniquitous. Under such circumstances it was but natural that, despite the treaty stipulation that Korean courts could entertain actions brought by foreigners against natives, such cases were always turned into international questions by foreign complainants, who preferred to seek redress through diplomatic channels.

Such was the condition of judicial administration in Korea when Japan established supremacy in the peninsula in 1905. In the year following the residency-general, while avoiding the introduction of any radical reform in the organization of the Korean courts, caused the Seoul government to engage a Japanese councillor and assistants in the Department of Justice who should take an active part in the administration of judicial affairs and superintend the revision of laws and ordinances. At the same time, the number of judges and clerks in the Court of Cassation and the Seoul Local Court was increased, and a Japanese assistant was attached to each of these courts. A Japanese assistant was also appointed to each court held by governors or prefects, while a Japanese police adviser was stationed in each district to act as legal assistant in the court of magistrate. This tentative measure, unsatisfactory as it was, was not without some good results. Thus the system of torture was abolished; arrests on civil charges were forbidden; detention of alleged offenders in the court-house was stopped; and all judges were strictly charged to keep the records of decisions rendered by them. 
Yet the evils of the old system were so deeply rooted that nothing short of its complete rehabilitation could attain the desired end. Consequently by the agreement of August, 1907, Japan secured from the Korean government a pledge to separate the judiciary from the executive as the first step towards a thoroughgoing judicial reform. In pursuance of this promise the Korean government, with the assistance of the residency-general, enacted in December, 1907, regulations for the organization of the courts. Thus the country was provided with a court of cassation or supreme court, three courts of appeal, eight local courts, and II 5 district courts. The system adopted by Korea is what is commonly known as "three trial system," which is in practice in Japan as well as in Continental Europe. The district and local courts hear civil and criminal cases in first instance. A case originating in a local court goes up to a court of appeal, while a case brought up from a district court to a local court must be referred directly to the Court of Cassation. In the district courts the hearing is before a single judge, but in the other courts the bench is collegiate.

In putting this system into practice the residencygeneral, on account of the impossibility of finding honest and competent judges among the Koreans, was forced to appoint Japanese to the following offices:

I. A chief justice, a chief procurator, two judges and five clerks in the Court of Cassation.

II. A chief justice, two judges, a chief procurator, an assistant procurator and five clerks in each of the three Courts of Appeal.

III. In the eight Local Courts the chief justices, the senior procurators, thirty-two judges and eighty clerks.

IV. A judge and a clerk in each District Court. 
When the new judicial system was adopted in August, 1908, the Korean courts of law became to all appearances a Japanese institution. Yet they were controlled by the Korean government, and not by the residency-general; and the Japanese judges attached to the courts were amenable to the authority of the Korean Minister of Justice. Furthermore, the Japanese judges and procurators found it in many cases impracticable to render full justice to the litigants when their only instrument was the Korean laws, which were deplorably inadequate. Then again, these courts, though virtually Japanese, had no jurisdiction over the Japanese in Korea, except where action was brought by a Japanese subject against a Korean. Japanese in Korea were subject to the jurisdiction of residential tribunals. To do away with the obvious disadvantages of such a system, the Japanese government secured, in 1909, a convention in virtue of which Korea intrusted Japan with the execution of judicial administration. Thenceforth the courts in Korea became Japanese courts not only in reality but also in name.

The new convention provided that Japan should bear all expenses connected with the administration of justice and prisons in Korea. Another noteworthy feature of the convention was that Korean subjects were made eligible for seats on the bench and posts in the management of the prisons. While it may reasonably be presumed that Koreans, by reason of their lack of legal knowledge and training, can, for the present at all events, aspire to no higher position than that of an interpreter, they will at least console themselves in the thought that they are not conventionally discriminated against. To the credit of Japan, it is fair to add that the Japanese administration at Seoul is making apparently unselfish ef- 
forts to encourage the natives in the study of modern jurisprudence. It has promulgated regulations for judicial examinations, by virtue of which native aspirants for judgeships and procuratorships, as well as those desiring to practice at the bar, are given an opportunity to prove their abilities. According to these regulations, the examination consists of two parts, written and verbal, and only those successful in the former are allowed to take the verbal test. The subjects for written examination include the civil, criminal and commercial laws, laws for civil and criminal procedure, administrative and international laws, while the subjects for the verbal examination are taken from three of these laws. Whether or not Koreans will derive any benefit from these regulations depends entirely upon their ability.

Side by side with the rehabilitation of law courts, Japan undertook to codify Korean laws. In 1906 Dr. Ume, Professor in the Law College of the Imperial University of Tokio, one of the leading framers of the Japanese Civil Code, was invited to take charge of this undertaking. Owing to the fact that in Korea the ownership of land was extremely ambiguous, laws regarding real estate claimed the first attention of the Japanese jurist, with the result that at the end of the same year "Land and Building Certification Regulations" were promulgated, the fundamental object of which was to guarantee to natives as well as to foreigners rights of ownership of real estate, on certifying, at a local magistracy or a Japanese residency, contracts for the transfer of lands or buildings by sale, exchange, gift or mortgage, and also to prevent any fraudulent transaction in matters of this nature. Simultaneously with this law, regulations governing procedure in the foreclosure of mortgages on lands and buildings 
were promulgated. In December, 1907, the Code Investigation Bureau was organized, and the work of compiling the codes of civil and criminal law and procedure devolved upon it.

The codification of these laws will not be completed for several years to come. In the meanwhile, to meet the pressing needs of the new courts, it has been found necessary to revise the native criminal law. Although enacted as late as 1905, the Korean criminal law was too severe in the punishments it prescribed. On the other hand, many penalties were lightened or commuted on payment of money. Moreover, in the administration of these laws so little independence was enjoyed by the judiciary that, in case of doubt as to proper application of laws, the judges in the Court of Cassation or in any other court must consult the Minister of Justice and decide in accordance with his opinion. With such defects remedied, the Korean laws will be in force until the new codes shall have become available.

Such was the status of judicial administration in Korea at the time of the annexation. As a rule the annexation will place the Koreans under the jurisdiction of Japanese laws; but considering peculiar customs and institutions of the country, the natives will continue to be governed by Korean laws. When the litigants consist of Japanese and Koreans, the case is to be treated according to the laws of the country the defendant belongs to. When the action brought is between foreigners, or when the defendant is a foreigner, Japanese laws are to be applied. This change of jurisdiction with regard to Americans and Europeans in Korea is the natural outcome of the annexation, which obviated the raison d'etre of the consular courts. Exterritoriality was established from the 
necessity of protecting foreign offenders against arbitrary proceedings of the native courts and the severe punishments of native laws, as well as the necessity of guarding foreign defendants in civil cases against whimsical decisions of Korean magistrates. In brief, the consular jurisdiction in Korea sprang into existence merely because the judiciary of the country was entirely out of touch with the spirit of the times. But, as the Shanghai Mercury, in discussing exterritoriality in Korea, says, where "the power in occupation has not only a code of laws in consonance with civilized standards, but has the official machinery suitable for putting that code in operation, there can be no question that a single judiciary working under that code, with all the inhabitants of the country amenable thereto, is the only possible means of securing not merely uniformity but elemental justice."

Speaking more directly on this question, this British paper in Shanghai says :

"With the establishment of the Japanese code for Japanese subjects (in Korea) the necessity for exterritorial privileges for Europeans and Americans ceases. In spite of those occasional lapses, that cause so much annoyance at times to Japan's best friends but are obviously inevitable in a youthful member of the family of nations such as Japan is, the Japanese code and its administration are recognized as being quite on a par with the judicial code and administration in European states, and if one reasonable and civilized judicial administration exists there is no need for others, and hence a natural step will be the abolition of exterritoriality."

The recent trial of the Korean assassin of Prince Ito at the Japanese court at Port Arthur furnished a golden opportunity for the new courts in Korea to gain the con- 
fidence of the Koreans. So sympathetic and impartial was the manner in which the culprits were treated throughout the entire proceedings of the case that foreign newspapers in the Far East expressed unstinted praise for the judicial integrity of Japan. Even the Kobe Herald, which is rather sparing in complimenting the Japanese, was on this particular occasion forced to say: "We doubt if the prisoner would have so much consideration shown him had he been before a Western court." The assassin, puffed up by some misguided notion, behaved so arrogantly before the judges that their patience and magnanimity were on many occasions most severely tried. Yet the court authorities manifested perfect self-control, and never allowed their sense of justice to yield to their feeling of pardonable indignation. The court was even inclined to allow a foreigner, an English barrister in Shanghai, to appear on behalf of the accused, but it was found that such a step was against the provisions of the Japanese law, which prevents a court from extending this privilege even by courtesy to a foreign lawyer. It was indeed surprising, as the Shanghai Times observes, to hear " the speech of the prosecution in a trial dealing so broad-mindedly with the old and new theories of criminal punishment, and the speech for the defense so openly and eloquently advocating the application of a contemptuous sentence as the best remedy for the prevention of crimes of the nature of that under review."

Japanese judicial administration is one of the many things which the censors of Japan have gibed and scorned at. Mr. Thomas F. Millard, for instance, in his "America and the Far Eastern Question" and "The New Far East," takes particular pains to tell the Ameri- 
cans not to trust the Japanese courts. Let writers of Mr. Millard's school say what they will: as for Japan, she can well afford to be serene and complacent with such critics, reposing full confidence in the verdict of an unbiased public.

I cannot conclude this chapter without reproducing a story told by Mr. S. F. Moore, of Seoul, through the columns of the Seoul Weekly Press-so illustrative is the story of the radical contrast between the old and the new administrative method in Korea. The story, in Mr. Moore's own language, runs as follows: " Last week my work took me to the country. Getting off the train at Dojo I started to walk to Pai Chun. A Korean who had evidently come down on the same train and who was going my way made my acquaintance and told me something that cheered my heart. He lives in a village in Pai Chun, owns some land, occupies the important position of land agent for a rich landlord who resides in Seoul. A short time ago this agent had been notified that a relative of his (a dissipated loafer) had, in association with a bad Japanese citizen, borrowed quite a sum of money in his name and squandered it in Seoul. He was ordered by his magistrate to either pay the money or go to Seoul to state what reason there was why he should not settle the account. (The initiated will understand that the rascals had a pull somewhere and expected to fleece the ignorant countryman, as is so commonly done here.) Having arrived in Seoul he had gone to the Japanese court where, to his surprise and satisfaction, the reprobate relative had been properly rebuked and spanked, while he was told that of course it was unnecessary for him to pay a debt contracted without his consent.

"As the Japanese rascal had run away, the judge told 
the agent that it was likely the confederate rascals would visit him later and try to get money from him somehow; at the same time he charged the agent that in case such an attempt was made he should first catch the Japanese rascal, bind him and send him up for trial, when he promised to administer the proper remedy in allopathic doses. Our friend, who had come expecting to be fleeced, as so many others have been, was quite astonished at this little bit of simple justice and felt that it would not do to go home without giving the Japanese judge some token of his appreciation; so next day he went to him and offered him twenty yen as a slight thank-offering for deciding the case in his favor. On doing so he was still further astonished at being told that he (the agent) must be a very nappon saram to offer money to a judge. He was told that such custom was unknown in Japan, and was advised to take his twenty $y e n$ and buy something for his parents or his family. This remark from the judge so upset all his previous ideas as to the usual proprieties in connection with lawsuits that he seemed to be in a sort of dazed condition-wondering if this was really a sample of the new era upon which the country was entering." 


\section{XIII}

\section{JAPANESE “OUTRAGES” IN KOREA}

T $\mathrm{T}$ is only three years since Japan assumed the control of Korean administration. Set this over against the 1 half-century that has gone by since England occupied India, or the generation which has elapsed since the establishment of British rule in Egypt, and we can readily realize how far removed from the desired goal the Japanese in Korea must yet be. True, the Japanese protectorate was recognized in November, 1905, but it was only in July, 1907, that Korea intrusted Japan with a direct supervision of her internal affairs. It would have been truly wonderful if the Japanese could have in three years put every part of the intricate machinery of Korean administration in perfect working order; it was not given to them to work such a miracle, and Japanese rule in Korea is to-day far from what they desire it to be. Indeed we cannot help blushing when we reflect how little we have contributed towards the betterment of conditions in Korea, after such critics as Mr. Alfred Stead held us out before the Western public as the model of "national efficiency."

The fundamental question which confronts us in Korea is the question of how to teach men of another race voluntarily to accept and to assimilate a superior civilization imposed upon them from without. It is the same question which America is trying to solve in the Philippines, and England in India and Egypt. It is perhaps 
unreasonable to expect Japan, the youngest of modern nations, to regenerate Korea in so short a period, when her schoolmasters in colonial administration are still struggling to overcome the difficulties arising from the antipathy of the peoples over whom they have for years been exercising suzerain authority. We see unrest in India assuming such portentous aspect that England has lately been forced to muzzle the native Hindu press; we find a nationalist propaganda looming greater and greater upon the political horizon of Egypt; we know that conditions in the Philippines are far from what they ought to be. And yet the Filipino's dislike of the Americans does not necessarily mean American maladministration in the Philippines; the disaffection in India and Egypt is no indication of British outrages in those countries. When we think of this the delicate and difficult nature of our task in Korea is brought forcibly home to us. Is it any wonder that Japanese administration in Korea has not been free from blemishes and blunders, which some Western critics have dragged into the garish light of day, branding them "Japanese outrages in Korea"? It, therefore, behooves us to inquire what these outrages are.

The Japanese in Korea have repeatedly been accused of treating the natives as the very scum of the earth. I frankly admit that in the early stage of the Japanese occupation of Korea many adventurers, and speculators and other undesirable characters came to the peninsula from Japan, all expecting to fish in troubled waters. The worst of these people were, perhaps, money-lenders and low-class laborers. The natural thriftlessness of the Koreans, coupled with a childish pride in actually possessing large sums of money, furnished eminently suitable traits upon which the unscrupulous usurer could build 
a thriving business. His favorite method was to loan money upon rice-fields in sums much below the actual value of the land. These loans bore high interest and were made for short periods; when the debtor failed to pay on the fixed date the creditor lost no time in foreclosing the mortgage.

Not less reprehensible was the conduct of low-class laborers. Puffed up by the notion that their country vanquished one of the greatest military powers of Europe, they vented their arrogance and their contempt for the Koreans by bullying and bluster. They apparently believed that they were, by right of conquest, entitled to handle their native neighbors as they pleased. It never dawned upon them that their acts were calculated to hinder the good work of the residencygeneral by alienating the sympathy of the natives as well as of foreign nations. Had it not been for the detestable conduct of this riffraff, Japanese rule in Korea would not have been made the target of scathing criticisms.

It must not be construed, as has frequently been done, that the influx of unruly Japanese into Korea was due to encouragement offered by the Japanese authorities. Critics who make such insinuations plainly admit that they have no substantial evidence to support their theory. Can a more flagrant violation of the code of honor be imagined than to charge a nation with the lack of moral integrity and the utter disregard of conscience, without any proof with which to justify such accusations? Yet this is exactly what some critics have been doing with regard to the Japanese case in Korea. The truth is that in the early days of the Japanese occupation of Korea the Mikado's government had its 
hands full in carrying on a gigantic war, and that when the war ended it was busy in readjusting its political relationship with Korea, with the result that its attention was not directed as much as it ought to have been to the control of undesirable Japanese entering into the peninsula. To accuse the Japanese authorities of inefficiency and inability is not unreasonable : it is decidedly unjust to say that they were hand-in-glove with usurers and low-class laborers in abusing the Koreans. In honor, then, let it be said that as the country resumes its normal condition, and as the Japanese authorities settle down to the arduous task of internal reform in Korea, the objectionable element of the Japanese population there is gradually weeded out, while the newcomers from Japan are of a law-abiding, industrious class, following their trades peaceably and legitimately without trespassing upon the rights of their native neighbors.

As soon as Prince Ito assumed his office as residencygeneral he made resolute efforts to put down the disorderly elements among his countrymen in Korea. His attempts met only with a lukewarm support on the part of the Japanese communities at large, while some agitators openly objected to his policy, declaring that it manifested unpatriotic partiality for the Koreans. The Japanese government and Prince Ito stood firm, and proceeded with the work to which they were committed, promulgating regulations for deporting undesirable Japanese and prohibiting the harmful practices of the money-lenders. The residency-general, in pursuance of these regulations, deported, during the three years from 1906 to 1908 , 107 Japanese, who were regarded as mauvais sujets. 
It would be unfair to attribute the whole blame for the estrangement of the Koreans to the mistakes made by the Japanese. The native officials, seeing in the advent of the new régime the termination of those happy days of fortune-making by extortion and peculation, cursed, at heart at all events, the reform measures inaugurated by the Japanese. The masses of the population perceived in the settlement among them of enterprising and industrious people the approach of an age of more assiduous toil and less pastime than they had been accustomed to, and were but too ready to lend ear to the seductive utterances of those who had selfish purposes to serve. The disbandment of the Korean army in 1907 injected another turbulent element into the already agitated situation, for the dismissed soldiers easily became desperadoes and increased the sum total of public misery by plundering defenseless travellers and raiding inoffensive villagers. Moreover Korea, like Manchuria, has for centuries been infested with bandits, the most formidable of whom are called hwa-jok, or armed robbers, who not only prey upon people of means, but often invade district magistracies and postoffices in order to purloin public money. With all these turbulent elements always at large it was no difficult task for malcontents and agitators to foment local disturbances, which were easily magnified into a patriotic rebellion, when reported in Western newspapers.

We are told that the maladministration of Japan has been responsible for the rising of insurgents which four years ago spread disturbance throughout the country. As a matter of fact, the so-called insurgents are nothing but robbers and brigands. The fact that these pseudoinsurgents prey more upon their fellow countrymen 
than upon the Japanese is strong evidence that their activities have nothing to do with the woe and weal of their country. The Japanese Chamber of Commerce at Mokpo in the province of South Chon-la, where the insurgents were for some time most active, inquired into the extent of damages they have inflicted on Jananese and Koreans during the three months from January to March, 1909. The result of this investigation is shown in the following table:

\begin{tabular}{|c|c|c|c|}
\hline & & Fapanese & Koreans \\
\hline of ince & ainst & 4 & 2 \\
\hline er of houses de & royed due to incendiarism & 8 & 4 \\
\hline of money $t$ & n from & $28 y e n$ & I,294 yen \\
\hline ed loss & to buildings of & . 900 yen & 1,760 yen \\
\hline to 10 & properties of & - 3,623 yen & 1,786 yen \\
\hline N & . . • • & 4 & 36 \\
\hline Number of wounded & .......... & I I & 16 \\
\hline
\end{tabular}

It will be seen that the Koreans suffered more than did their Japanese neighbors from the ravaging hands of "insurgents." This is especially noticeable in the number of killed and wounded and the amount of money taken by robbery.

At the same time it must be admitted that in the year or two immediately following the establishment of the Japanese protectorate some misguided Koreans took up arms against the Japanese from patriotic motives. The first insurrection of this nature broke out in the South Chungchong province in May, 1906. Its leader declared that he was a commander of the "righteous army," and that he had in view the emancipation of his country from the hand of the Japanese. Equipped with old fuse cannon and rifles, his followers attacked the Japanese gendarmerie, the post-office and district magistracy in the walled city of Hong-ju. The city was captured and 
made their headquarters. Levying contributions from the people by force, the insurgents inaugurated a veritable reign of terror throughout the region. But they were no equal of the trained soldiers who were rushed to the scene from the Japanese garrison army. In the encounters that ensued eighty insurgents were killed and 150 captured. The manner in which the Japanese authorities dealt with the captured insurgents was far from severe. Of the I5O prisoners eighty were pardoned on the spot and seventy brought to Seoul for trial. Even the ringleader was not sentenced to death-penalty, but was banished to Chin-do for life, that is, he was allowed to retire to that country and live the rest of his life quietly and peaceably; but he had been in exile only a few months when the Japanese authorities pardoned him unconditionally.

The next insurrection was instigated by a scholar of the old school. Having his headquarters in Seoul, he sent out to all parts of the country seditious literature, inciting scholars and young men in various provinces to the point of insurrection. Thus he succeeded in assembling a force of some 150 men in July, 1906, but these were soon obliged to surrender.

The abdication of the Korean emperor in the summer of 1907 was another occasion for riots, this time within the walls of the national capital. The riots were immediately put down by the Japanese military and gendarmerie so far as Seoul was concerned, but in the country districts disturbances of a more or less serious nature continued to prevail for some time thereafter, owing mainly to the fact that the disbanded soldiers, having squandered the allowance given them by the government, joined hands with insurgents and vented their discontent 
by plunder and pillage. From this time on the insurrection has lost all claim for patriotism, and become little better than brigandage. It is plain that the " tragedy of Korea " was enacted more by the folly and lawlessness of the Koreans than by the severity of the Japanese.

The situation in Korea was delicate enough without those foreigners always on the alert to seize upon every opportunity to prejudice the natives against the Japanese administration. The most mischievous of such foreigners were those who, with journalism as their weapon, openly attacked the residency-general, and instigated the natives to rise against the new régime imposed upon them. The most audacious of such journalists was Mr. E. T. Bethel, editor and proprietor of the Korea Daily News, whose Korean edition appeared under the title of the Taihan Mai-il Shinpo, and was printed both in the Korean alphabet and in Mixed Korean and Chinese ideographs. Mr. McKenzie, discussing, in his "The Tragedy of Korea," foreign journalism in Korea, endeavors to make it appear that the Japanese authorities disliked newspapers of the nature of the Korea Daily Newes simply because they were loath to hear foreign criticism. Admiring the enterprise of Mr. Bethel, Mr. McKenzie tells us that the Korea Daily Neres was able to keep up a handsome office, with safes, typewriters, and handsome electric fittings that would do credit to a daily with a circulation of 50,000. I am not less enthusiastic in admiring the ability of Mr. Bethel, but I would be the last person to indorse the policy followed by him. Emboldened by the rights of exterritoriality, which exempted him from the jurisdiction of the Japanese or Korean authorities, he published seditious news and comments both in English and in the native language. When 
Mr. D. W. Stevens was assassinated in San Francisco the Korea Daily News extolled his Korean assassins as "patriots" and as "loyal and righteous gentlemen" because they murdered a man who supported the Japanese protectorate. Again, this journal, comparing Prince Ito to Metternich, and Korea to Italy, made the following audacious remarks: "But at last patriotic sons of Italy rose up in great force, and with banners of right flying and with bells of freedom ringing, opposed him. That Metternich, who was like a devil, fox, and badger, had to put up the white flag, and fleeing his native country, to spend the rest of his life in a foreign land. This should serve as a warning to such as may have the same barbarous mind as Metternich, and like him plot against another country." Still another article referred to the " finger blood of the seventeen students," and said: "We will certainly recover our Korea. . . . What heroes have left glorious monuments in history except through blood?" If the Japanese authorities failed to suppress the journal, it was not because it wielded too great a power, as Mr. McKenzie seems to think it was, but merely because its editor hid himself behind the bulwarks of exterritoriality.

The incendiary activities of the Korea Daily News became so rampant that the British consul in Seoul, in accordance with the provisions of the "Order in Council of 1904," was obliged to summon Mr. Bethel and order him to give a bond of $£ 300$ for six months, and "to keep the peace and guarantee his future good behavior." During that period the journal behaved with comparative moderation, but as soon as the term expired its seditious activities were resumed with greater energy, until the Japanese resident in Seoul was obliged to lay a complaint before the British Consular Court against $\mathrm{Mr}$. 
Bethel. The public hearing of this case, which lasted from the $15^{\text {th }}$ to 18 th June, 1908, resulted in a judgment which sentenced the accused to imprisonment for three weeks and required subsequently " to give security for good behavior during six months or to be deported." In the text of the judgment we find the following significant passage:

"It comes to this, that you [Mr. Bethel] being a foreign guest in this country and owing a duty of quiet, orderly conduct to its government in return for the protection they extend to you, set yourself up as a paper leader of insurrection with this court as a sanctuary to flee to in case of danger. In what respect can you be a real leader in the forefront of the battle with your life and family and property at stake? Suppose they follow the advice of your editor and take up the sword, where will you be when their blood is flowing? Without at all questioning your courage or disinterested motives, I say you are in a false position and likely to do the most grievous harm to the people you wish to befriend. It is my duty to warn you that if you continue to preach rebellion you must be deported."

I have dwelt at length upon foreign journalism in Korea because it was one of the factors which conspired to incite rebellion among the masses of the Korean population. But it must not be presumed that Japanese authorities were partial to the newspapers published by Japanese subjects in Korea. So far from it, where comments of these papers were found injurious to the peace and order of the country, the residency-general did not hesitate to adopt rigorous measures. Thus during 1908, the Keijo-shimpo, one of the leading Japanese papers in Seoul, was suspended its publication three times; the 
Chosen-nichi-nichi, of Seoul, twice; the Taikan-nippo, of Seoul, once; the Chosen-shinbun, of Chemulpo, three times; and the Fusan-nippo, of Fusan, once.

The native hostilities stirred up by discontented offcials, disbanded soldiers, foreign journals, brigands and pirates, accomplished nothing in the way of improving conditions in Korea, but resulted in fatalities to about I 5,000 Japanese and Koreans, besides inflicting untold misery upon the innocent, peaceful people. Fortunately the insurgent movement was soon exterminated. During the campaign of the Japanese military against the insurgents the most blood-curdling tales were told by such writers as Mr. McKenzie about the cruelty of the Japanese. But as Mr. W. T. R. Preston, for several years Canadian Trade Commissioner in Japan, writing in the Toronto Globe, says :

"Many of the stories have no foundation in fact, and others have been greatly exaggerated. Every one is well aware that war is war. Passions are let loose that under other times are subject to absolute control. Korean insurgents have been met by Japanese, and, refusing to surrender, have been annihilated. Japanese troops have met with the same tragic fate at the hands of Koreans. Some Japanese troops passing beyond the control of their officers have been guilty of serious offenses against the rules of warfare, but the cases that have come to the knowledge of the authorities have been dealt with as unsparingly as the British commander-in-chief did in two or three notable instances during the South African war. - . But it is charitable to express the hope that when all is known of the Japanese operations in Korea, it may be found that the military have been as tolerant as they were with Russian prisoners in the late war." 
What more can we add to this just interpretation of the situation? This, forsooth, is the real nature of Japanese " outrages" in Korea.

One of the gravest charges directed at the Japanese authorities is that during their military operations against Russia they appropriated private lands in Korea in a most arbitrary manner. The appropriation was made in pursuance of the protocol of February 23, 1904, which conceded to Japan the right to occupy "such places in Korea as might be necessary from a strategical point of view." But it is not the right itself, but the method in which it was put into practice, that has been vehemently attacked by foreign critics. Thus we are told by Mr. Hulbert that the Japanese :

"Have gone in and seized the most valuable property in the vicinity of the largest towns in Korea. When the people ask for payment, they are told to go to their own government for payment. But the Japanese know that the government has no money and that the land is simply confiscated. But not only so; men claiming to be connected with the Japanese army go out into the country districts and seize any land they like, repeating simply the formula 'this is for military purposes."

I do not desire to enter into controversy with $\mathrm{Mr}$. Hulbert, but I may be permitted to set forth facts which, in the light of my investigation, are authentic.

In July, 1904, the Japanese authorities appropriated for military purposes some 8,264 acres in Yong-san, Ping-yang, and Shin-wiju, as well as 1,500 acres to be used in connection with the construction of three military railways-the Masampo, the Seoul-Shinwiju, and the Seoul-Wonsan line. Japan promptly took steps towards compensating the owners for the appropriated 
land, handing over, on August 10, 1904, 200,000 yen to the Home Department of the Korean government, to be distributed as partial reimbursement for lands formerly owned by private individuals in Yong-san, Ping-yang, and Shin-wiju. But confusion concerning the survey of the lands and their appraisal, as well as the difficulty of distinguishing public lands from private lands, greatly deterred the settlement of the matter, thus causing much misunderstanding on the part of some Koreans. Recognizing the necessity of a speedy settlement the Korean government, at the request of the residency-general, organized, in October, 1907, a temporary bureau for the purpose of investigating into all questions relating to the lands appropriated by the military authorities. The director and secretary of the bureau were Koreans, a Japanese officer, and a civil engineer having been attached to it only as counsellors. Prior and subsequently to the creation of this bureau more than half of the lands occupied for military purposes at the above-named three towns were restored to the original owners or transferred to the Railway Bureau of the residency-general, so that the lands actually remaining in occupation by the army were reduced from 8,264 acres to 3,578 acres. Of these 3,578 acres, 2,392 acres were appropriated from private lands, for which 264,604 yen has been paid by the Japanese army.

The lands transferred from the army to the Railway Bureau to be used as station sites at Yong-san, Pingyang, and Shin-wiju aggregated 804 acres, of which 649 acres belonged to private individuals, requiring the reimbursement of 60,453 yen by the Japanese government.

As for the lands appropriated for the above-named 
three railways-the Masampo, the Seoul-Shinwiju, and the Seoul-Wonsan line-their total area originally amounted to 14,876 acres, but as the result of readjustment it was reduced to IO,40I acres, of which 2,08 I acres were public lands. For the remaining 8,320 acres, belonging to private individuals, the Railway Bureau paid 590,605 yen.

This, then, is the real substance of the story which, as told in Mr. Homer B. Hulbert's " The Passing of Korea," appears in this distorted form:

"The Japanese military put their hands upon eight square miles [5, I 20 acres] of the most valuable land near Seoul simply for the building of barracks and parade grounds for twelve thousand men, when experts affirm that one-sixteenth of that space would have been ample. That land could not be bought in open market for six million dollars, but the Japanese knew the government could not pay a proper price, so they gave two hundred thousand dollars, to cover the cost of removal only. And this is all the Koreans could ever hope to get."

The land referred to by $\mathrm{Mr}$. Hulbert could be no other than that at Yong-san which I have already mentioned, for in no other place near Seoul did the Japanese military occupy any land. If this be so, Mr. Hulbert's accusation widely misses the mark. The area of the land in question, instead of being 5, I 20 acres, as Mr. Hulbert represents it to be, did not exceed 2,479 acres. Of this total 905 acres were afterwards restored to their original owners, while $40 \mathrm{I}$ acres were transferred to the Railway Bureau to be used as station site, fair compensation having been made therefor. Thus the land permanently occupied by the army at Yong-san was reduced to I, I 73 acres, of which 429 acres belonged 
to the Korean government and required no compensation. It comes to this that the private lands permanently appropriated by the Japanese army aggregated 744 acres only, for which IOI,956 yen has been paid, averaging I 37 $y \in n$ per acre.

I cannot conclude this chapter without saying a few words about the regrettable conditions resulting from the fact that the Japanese officials, lacking the knowledge of the Korean language, are forced to employ interpreters, mostly Koreans, in carrying out administrative measures. Now the interpreters are not always honest, and the dishonest interpreters are dreaded by the people even as are the thieves. Let me illustrate their favorite method of extortion. A Japanese officer desires to obtain so many sacks of barley or rice, and negotiates for them through an interpreter. The cunning interpreter transmits the order to the villagers, but demands much more than the amount asked for. The villagers would say they are unable to supply so much, whereupon the interpreter comes back with feigned disappointment and indignation and tells the officer, in such a way as would arouse his anger, that the villagers refused to negotiate. The rascal then goes back to the people, saying that the Japanese officer is coming to chastise them. The Koreans, seized with fear, entreat the interpreter to appease the officer's anger, promising a generous payment to the wretched man. As if by enchantment, they are informed that the Japanese has consented to take much less than he asked for at first. The officer goes off with the amount he actually wanted to obtain, and the bad interpreter laughs in his sleeve when the innocent villagers express their gratitude with the payment of a substantial sum. 
Here is another example of trickery. The interpreter goes to a rich man and transmits a verbal order to present himself at a certain Japanese office. "Why?" he demands. "I am not to tell you," responds the interpreter, "but you must follow me." The rascal then intimates that the rich man is suspected of being in complicity with insurgents, and that the Japanese are resolved to punish him severely. "Is there any way of eluding the Japanese order?" asks the terror-stricken man. The interpreter apparently sympathizes with the poor fellow, and assures him that he will do all he can to secure a pardon if a liberal sum of money is provided for his disposal, so that he may bribe the Japanese officers. The money is paid, and the interpreter disappears, while the Japanese are cursed by the defrauded man for what they have no knowledge of.

The evils of employing interpreters in the administration of government are too obvious to require any elucidation. Japan has inaugurated in Korea an admirable system of law courts, but the inability of Japanese judges to speak the Korean language has militated against making the institution as perfect as it should be. Japan's reputation has suffered enough through the pernicious conduct of interpreters, and it is up to her to adopt measures for the speedy elimination of this undesirable element from Korean administration. 


\section{XIV}

\section{THE ANNEXATION OF KOREA}

A fire took place in our house;

The thatched cottage is gone.

'Tis sad, exceedingly sad;

Yet there's one thing that rejoices us :

Those cruel bedbugs, which sucked our blood, Were all destroyed in the fire.

HIS is a literal translation of the song that was heard jauntily sung in the streets of Seoul for 1 some time before the annexation. The great political convulsions which had shaken their country to the foundation could not help impressing even the people upon whose minds care sat most lightly. Some bard or songster scented the popular feeling and expressed it in this song. A foreign overlord had come to rule them, and the sovereign rights of their state had been snatched from it one after another. It was as if a house caught fire, reducing its beams and pillars into smoldering embers. It was a sad plight in which they found themselves. And yet the misfortune was not entirely without its consolation: the yangpan that had led a life of idleness, luxury, and caprice at the expense of the common people, had been deprived of much of its arbitrary privilege and power, and the termination of the vile practice of extortion and blackmail perpetrated by the privileged class seemed well-nigh at hand, thanks to the advent of Japanese rule. Bedbug - that was the unceremonious appellation which the song bestowed upon the parasitic yangpan. 
The yangpan's position in Korea was not dissimilar to the position of the French nobility prior to the great revolution. It was exempt from taxation, and indeed from all duties to the state, but subsisted by virtually preying upon the common people. Official positions were exclusively reserved for it to be utilized for the exploitation of the populace. Men of the yangpan caste were thus enabled to maintain a seraglio and a large retinue, and indulge in vice and luxury without contributing aught towards the welfare of the state, while the masses of people were harnessed to toil without the least hope of recompensation.

But the time at last arrived when the plebeian sons of Korea were enabled to rise against the aristocracy and shake off the yoke of tyranny. The picturesque career of Song-ping-shun, the man who led this new movement, need not be recounted here: suffice it to say that whatever success was attained by the movement was wholly due to Japanese influence which was behind Song. When the Russo-Japanese war broke out, the Japanese army enlisted a large number of Korean laborers to be employed in connection with the transport service. In this Song saw a golden opportunity to attain his cherished ambition. He lost no time in offering his service to the Japanese army by supplying men and provision. The motives which prompted him to take this course were perhaps not entirely unselfish. It is probable that his chief interest was in fortune-making rather than in political reform. A sagacious man, he did not fail to discern a lucrative job in the service which he volunteered to render the Japanese. By furnishing the Mikado's army men and provision, he could pocket a handsome commission, and, what was more important, could secure the 
favor of the Japanese authorities, which might be utilized for his own benefit, should Japan acquire mastery of the peninsula.

But the motive does not matter. What is important is that he became the actual leader of a large force of men whom he assembled for the Japanese military authorities. The force consisted mostly of men of the plebeian order who had long been oppressed by the yangpan. Some of them were ignorant coolies, some peaceable common people, not a few rowdies and malcontents who openly cursed the aristocracy. However dissimilar they may have been in temperament and character, they were like one man in that they all nurtured hatred of the yangpan and desired its downfall. Song himself, having sprung from the downtrodden class, was in sympathy with the general sentiment among his men. So this band of Koreans, originally enlisted to serve the Japanese army as transport laborers, gradually and unconsciously assumed the nature of a political faction whose purpose was the curtailment of the influence of the yangpan. Some of the men were no doubt animated by a spirit of revenge, and gave vent to their enmity and discontent by means not always reputable. Their acts were perhaps pardonable, considering the oppression and persecution to which they had been subjected at the hands of the privileged class. Yet it was nevertheless deplorable as it only resulted in widening the gap of hostility that had opened between the aristocracy and the common people. Moreover, their invocation of Japan's name in perpetrating harmful conduct did not fail to injure Japan's reputation, at least in the eyes of the privileged class of Koreans.

To all appearances Song was a staunch and consistent 
advocate of Japanese protectorate, and he had the courage to preach his political convictions in the face of the yet powerful yangpan and official cliques, which acquiesced in the new order of things only reluctantly. His sagacity, his energy, his magnetic power, and the tactfulness of his movement were such that he succeeded in gathering nearly three hundred thousand men under his standard.

Japan was not unappreciative of Song's unremitting toil for the cause of the new regime, and when Prince Ito assumed duties as resident-general in 1907, the lamented statesman persuaded the Korean emperor to appoint Song to the post of Minister of Home Affairs. Korean officialdom composed of men who sprang from the yangpan class regarded this " upstart "statesman with mingled contempt, distrust, and disgust; and yet they were forced to recognize the great influence that was behind their new colleague. How could they ignore a man controlling three hundred thousand followers whose watchword was reform and progress? The appointment of Mr. Song to the post of a minister marked a new epoch in the political history of Korea, for it was a tacit recognition by the privileged class that the masses of people could no longer be abused and oppressed as they had been.

Song's mission was twofold: on the one hand, he stood for the emancipation of the common people, and on the other he toiled for the promotion of Japanese influence in the government. It is the second phase of his mission that we are chiefly concerned with here, for his consistent championship of the Japanese cause was no doubt one of the factors which facilitated the annexation of Korea by the Mikado's Empire. Although Mr. Song's indiscreet utterances with regard to the Christian missionaries in Korea resulted in his dismissal from the government at 
the behest of the very Japanese statesman who had recommended him to the Korean emperor, his star as a political leader did not wane. His hold upon his followers was too strong to be broken by the loss of his official honors. A politician capable of holding together a large following under adverse circumstances as well as when fortune smiled upon him-a man of so remarkable a personality had to be reckoned with, whether he was in or out of the government.

Mr. Song's dismissal occurred in February, 1908. By that time he had clearly discerned that the ultimate and inevitable destiny of his country was its fusion with Japan. He had seen that the independence of Korea had become naught but the merest sham, with his countrymen having neither the desire nor the ability to regain it. He had been forced, however reluctantly, to admit that the corruption of the court and officialdom, and the impotency, indifference, and supineness of the people in general had become such as to make the regeneration of the country, without the direct and constant application of strong influence from outside, an impossibility. Once such influence was removed the nation would ever cease to advance, and fall back into the quagmire of factional feuds, court intrigues, the exploitation of the masses, and all that constituted a state of anarchy. If the Korean people were so utterly devoid of the qualities requisite for an independent nation, what was the use of investing it with a pretense of sovereign rights? The maintenance of such sovereignty on the part of Korea had not been innocuous, but had proved a serious hindrance in the way of reform. The dual administration formed by the Korean court and the Japanese residency-general had accomplished much for the amelioration of conditions in 
the peninsula, but in its actual working it had been found far from satisfactory. The Korean statesmen and officials, ever longing for the old days of corruption, were always at cross purposes with the residency-general, so that good measures initiated by the latter fell far short of attaining the end for which they were conceived. The local functionaries, who were in direct touch with the people, were as corrupt as the high officials in the central government; at their hands those laws, intended for the promotion of the welfare of the masses, were in most cases converted into a dead letter. If the native government ceased to exist, and handed over to the Japanese its last vestige of power, the cause of reform and progress would be served much better. Then the Japanese authorities would be free not only to initiate laws and regulations, but also to put them into execution without encountering obstructions and hindrances from corrupt native officials. Thus, only thus, the process of reform in Korea would be greatly simplified, and the longabused common people would really begin to bask in the blessing of the new régime.

Such was the thought which caused Mr. Song to advocate the amalgamation of Korea with Japan. Towards the end of 1908, he confided this idea to a few Japanese statesmen, Prince Ito one of them. But Japan at that moment was not inclined to take any measure towards the final obliteration of Korean independence, and offered no encouragement to Song's suggestion. Then happened the assassination of Prince Ito. In this regrettable incident Mr. Song saw the psychological moment to openly advocate annexation. He had both the tact and influence to convert his followers to his political convictions; and in October, 1909, his political party, the Il Chin Hoi, 
passed a resolution declaring that annexation was the only satisfactory solution of the Korean question, and memorialized both the Korean emperor and the Japanese government accordingly. By that time Japan had been forced to admit that affairs in Korea had not been going right, and had already formulated her policy for the eventual annexation of the country. Prince Ito's trip to Harbin, where he was assassinated, was probably undertaken for the purpose of obtaining Russia's consent to the annexation. But the Japanese government was unwilling to carry out the new policy at the recommendation of the $\mathrm{Il} \mathrm{Chin} \mathrm{Hoi,} \mathrm{fearing} \mathrm{that} \mathrm{such} \mathrm{a} \mathrm{course} \mathrm{would}$ make it appear that it was partial to a political faction in Korea. Then again, had Japan annexed Korea in the wake of the Harbin tragedy, the world may have suspected that she was acting in a spirit of revenge. What appeared to Song a psychological moment seemed to the Japanese government and people the most unopportune moment to assume any measure towards the annexation. So the matter received no serious consideration in Japan, and was entirely dropped for the time being.

Meanwhile Mr. Song's action was subjected to the severest criticism at the hands of the privileged class in his country. He was accused of conspiring to sell his country to Japan for some unholy purpose. And yet Song was not daunted, and continued to advocate annexation, in the face of sarcasm, insinuations, and malignment hurled at him by the men of the yangpan class. He was convinced that the stage would soon arrive wherein the Japanese statesmen would be forced to execute the measures they had already outlined. And he was right.

In August, I9Io, Viscount General Terauchi, Japa- 
nese Minister of Army, was appointed to be the residentgeneral. He proceeded to his post, authorized to negotiate for the annexation. Viscount Terauchi's manner in handling the delicate matter was admirable. While not unappreciative of the valuable service rendered Japan by Mr. Song and his party, General Terauchi was too sagacious to show partiality towards the Korean politician, knowing that such a course would inevitably sow seeds of enmity among various political factions in the peninsula, where harmony was needed most. It was no doubt the part of wisdom to deal in a spirit of fairness with all factions, whether pro-Japanese or anti-Japanese. None of the Korean political parties, if such they could be called, was animated by public spirit, not, indeed, even Mr. Song's. Their leaders all had some selfish purpose to serve, and cared little whether their country remained independent or not. The country had had more than enough of chaos and disturbance engendered by the strife among these petty factions, and it was high time that they should be terminated once and for all. By showing no favoritism towards Mr. Song's faction, but by treating all parties with impartiality, Viscount Terauchi could command the respect and confidence of all, creating with none a feeling of suspicion and distrust. The $I l$ Chin Hoi and its leaders were doubtless a little disappointed by the attitude of Viscount Terauchi, but even they must at heart have recognized that this attitude was unimpeachable.

Viscount Terauchi's instructions given to his countrymen in Korea were equally commendable. Upon the officials he urged economy and industry in conducting their official business. To the Japanese community in general he offered the advice that moral laxity, usually 
prevalent in colonies and frontier territories, should be carefully avoided. Above all he endeavored to bring home to all classes of Japanese that it was their foremost duty to treat their Korean neighbors with sympathy and kindness.

Simultaneously with the treaty of annexation, which was signed on August 22, 1910, Viscount Terauchi issued a proclamation defining the treatment to be accorded to the imperial household of Korea and indicating the nature of Japanese policy to be adopted in Korea after the annexation. In the first place, the Korean emperor, though no longer wielding political authority, was allowed to maintain and enjoy the same personal dignity and comfort as before. He was to be known by the title of $\mathrm{His}$ Imperial Highness $\mathrm{Yi}$ Wang (Prince $\mathrm{Yi}$ ), and the crown prince to be called Prince Heir, while the exemperor was to be given the title of His Imperial High. ness Tai Wang (Prince Father). Their highnesses are accorded the treatment of Japanese princes of the blood, receiving annual grants as munificent as before.

Nor did Korean ministers and other officials fail to receive due consideration. Some of them were created peers and had conferred upon them monetary grants appropriate to their rank and merits; some were appointed to be members of the newly created Central Council, an advisory body to the Japanese governmentgeneral of Korea; while others were made officials either of the central or of the local offices. Even the yangpan class, which contributed little to the welfare of the country, was not entirely left in the cold, for those of its members whose records were not decidedly bad were accorded special awards. Local functionaries who misappropriated public money were freed from their respon- 
sibility and exempted from paying in the balance of the sum due.

Equally generous were measures taken with regard to the masses of people. It was officially announced that dutiful sons, virtuous wives, and other persons whose behavior was exemplary should be duly rewarded and publicly honored. In view of the fact that centuries of maladministration entailed universal impoverishment of the masses, the people were exempted from paying the land tax, which was due until 1908 but remained unpaid, while those who borrowed public grain before the end of 1909 were not required to return it. In addition, the land tax due in the autumn of I9IO was reduced by one-fifth of the rate. Further, a sum of about seventeen million yen was advanced from the treasury to be donated to 238 districts of the thirteen provinces, so that the people would be enabled to settle down to the pursuit of industrial work and promote their wellbeing in other respects. In addition to the Central Hospital and three charity hospitals opened a few years before, a charity hospital was to be instituted in each province to confer upon needy patients the blessing of advanced medical science. Even those who contravened the laws were not forbidden to share the benevolence of the new administration, especially where the nature of offense was found deserving extenuation. Thus hundreds of prisoners have been set free, many of them being given money with which to return to their homes.

The annexation has necessarily brought upon Japan a heavy burden of new responsibilities, especially in the matter of finance. To meet the extraordinary expenditure, entailed by the creation of a new peerage, the reduction of the land tax, the grant of a beneficial fund 
to the people, and other benevolent measures, the Japanese government has decided to raise a national loan to the maximum amount of 30,000,000 yen. From the view-point of Japan's own benefit it is open to question whether the annexation is desirable or not. Yet Japan was obliged to take the step she did, if she was to complete the task she had embarked upon.

We have considered the effects of the annexation upon Korea herself; it remains for us to examine its effects upon the interest of foreign nations.

One of the inevitable results of the annexation is the abolition of exterritoriality. This question has already been minutely discussed in connection with judicial reform in Korea.

Of more serious concern to Western nations is the question of foreign trade with Korea. As a principle, the abrogation of Korea's foreign treaties, which is the corollary of the annexation, should ipso facto imply the nullification of the tariff schedules agreed upon between Korea and foreign countries. But in view of the fact that the annexation was necessitated chiefly by considerations of a political nature, the Japanese government is anxious not to disturb the economic interest of foreigners in Korea, and is moreover conscious of the advisability of abstaining from measures which may bring about radical changes in the commercial relations between Japan and Korea. It has therefore decided to maintain the customs tariff hitherto enforced in Korea, for a term of ten years, in respect of trade, foreign as well as national. For the same period the existing tonnage dues are to be maintained; foreign vessels will be allowed to participate in the coasting trade of Korea; while all the open ports, with the exception of Masampo, which is to become a 
naval base, are to offer the facilities of access hitherto obtaining. The exception of Masampo will in no way affect foreign commercial interests in the peninsula, as the port has never had any foreign trade. Shin-wiju, which has been opened as a substitute, is from a commercial point of view far more important than Masampo. Moreover, the extension to Korea of Japan's existing treaties, while abolishing the right of exterritoriality, will confer upon resident foreigners in Korea the privilege of residing and trading in all parts of the country, as well as other rights and privileges now enjoyed by foreigners in Japan proper. It will be observed that for the next ten years the barrier of tariff will still stand between Japan and Korea, which may retard the growth of Japanese trade in the newly annexed territory. Is this not an indication of Japan's consistent intention to give foreign economic interests a square deal? The decade's respite ought to afford foreign enterprise an ample chance to consolidate the foothold which it has already obtained in Korea. 


\section{XV}

\section{AMERICAN ENTERPRISE IN KOREA}

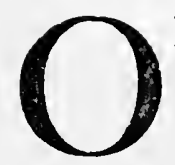

$\mathrm{F}$ all Western nations the United States has the greatest economic interest in Korea. True, she ranks next to Great Britain in the import trade of the peninsula, and also to Russia and Holland in its export trade. But the true extent of American interest in Korea cannot be gauged merely by the volume of her trade with that country: we must take into consideration the various enterprises which have been started by American citizens in different parts of the empire. The principal mining industries, the first railroad ever built in Korea, and the first electric trolley line, electric lighting plant, water-works and telephone system in the Korean capital -these are all fruits of American economic activities in the Hermit Kingdom.

The great strides which American enterprise has made in Korea are perhaps largely due to the influence which Dr. Horace N. Allen, for many years American minister at Seoul, exercised in the Korean court. A personal friend, physician and adviser for the Korean emperor, he was in a position to assist his nationals in their efforts to obtain various concessions in Korea, and used his influence to promote and encourage American undertakings where they were found legitimate. His efforts, however, would have hardly been rewarded with so great a success, had it not been for the initiative of an American citizen whose bold spirit of speculation and whose un- 
daunted courage made him unusually fit to open up a country which was shrouded in an almost mythological atmosphere. This American is Henry C. Collbran, of Denver. Before going to the Far East, Collbran was prominently connected with the construction of the Midland Railway. Soon after his arrival in Korea early in the nineties, he was commissioned by an American syndicate to build a railroad connecting Seoul with the Chemulpo anchorage. A line of only twenty-six miles, its construction was nevertheless an exceedingly important undertaking, for the road, if road it could be called, between the capital and the port was so wretched that foreign travellers accustomed to modern conveniences found it practically impassable. An old-time traveller in Korea, describing his journey over this road, says :

"I had to have a pony and eight men to bring myself and wife to the walls. I rode the pony and the madame came in a chair, borne on the shoulders of four coolies, with a relay of four others to help them. Towards the end of the journey we had to push on for fear that we might not get to Seoul before the gates closed. The city is surrounded by a massive wall nine miles in length and thirty feet high. At that time this wall was entered only by gates, and these were closed at night by heavy doors plated with iron which were not opened again until the next day. We got in just in time to see the gates close."

This undertaking of Collbran's was naturally most heartily appreciated by all foreigners in Seoul. Although the American syndicate sold the road to the Japanese before it was completed, it remains a worthy monument to American enterprise, which undertook its construction when the prospect of its successful operation was far from bright. 
Soon after the Seoul-Chemulpo Railway was off his hands Collbran organized a firm under the name of "Collbran and Bostwick Development Company," and obtained the concession to build an electric trolley line in Seoul in connection with a lighting plant. When the trolley line was opened the natives entertained prejudice against it, and on several occasions cars were attacked by mobs. They believed that the innovation might result in fearful drought which would destroy the crops. Their theory was that as the cars looked like boats sailing to and fro through the streets, the gods of rain, peering down from the heavens, would say: "These people live in a city floating on water," and would pass on without giving them a drop of rain. The car line runs through two of the main gates, all of which now stand wide open day and night, and on out into the country. The picturesque theory of the natives seems to have crumbled before the rude argument of demonstrated facts, for they are to-day fairly good patrons of the line.

Before the installation of an electric lighting plant by the firm of Collbran and Bostwick all Seoul was pitch dark at night. At that time no men of the plebeian order were allowed to go about after dark, but women, irrespective of class, were at liberty to appear in the street. This seems rather strange in a country where women are shut up in the "inner apartment," but the theory was that the members of the imperial family as well as officials, who were exempt from the rules governing the common people, might with impunity indulge in dubious conduct, descending sometimes even to obscenity, when women were out in the dark without any masculine escort. In these days it was not seldom that a young maiden or a married woman suddenly disappeared while taking her nocturnal 
stroll, and failed to return home for months or years. In such cases it was generally believed that the woman, on account of her rare beauty, had been marked by the emperor or a prince or a high official. In a country like Korea, therefore, dark streets meant moral degradation, and the first lighting plant in Seoul had attached to it a far greater significance than was indicated by the material convenience which it introduced. But the lighting system inaugurated by Collbran and Bostwick was restricted to a small section of the town, and it remained for the Japanese to enlarge upon the old plan and convert benighted Seoul into a tolerably well-lighted town, for the firm disposed of the lighting plant as well as the street-car line in favor of the newly-organized Japanese firm known as the Japanese-Korean Gas and Electric Company.

Collbran's next undertaking was the installation in Seoul of a system of water-works. Sanitation in Korea has been conspicuous only by its absence. Where Japanese influence is not yet felt the front gate of a native house is often adorned with a slimy pit into which the filth and rubbish are dumped, and the infiltration from the malodorous cesspools pollutes the well water until it is unfit to use. Indeed the impure well water has been the cause of terrible epidemic diseases which scourge the country almost every year. In the summer of 1886 nearly a thousand people died every day of cholera caused almost wholly by impure water. Collbran's undertaking to put in water-works in the Korean capital was perhaps the greatest boon ever conferred upon the city, and especially its foreign community. In this great work Collbran and Bostwick acted as the agent of a British syndicate, the Korean Water-Works Limited, to 
which the American firm sold the concession in August, 1905, but the fact remains that its successful execution was due to the initiative and business acumen of American citizens. The work, which entailed a cost of millions, was finished in August, 1908, and the water has been immediately turned on to be delivered at the door or in the house. The water is drawn from a point on the Han River, three miles from Seoul. It is first delivered into settling reservoirs, with a capacity of $2,496,000$ gallons, by centrifugal pumps, and then passed through sand filter-beds, gravitating into a clear water tank having a capacity of 256,000 gallons. From thence it is pumped through a twenty-one inch steel main, two miles in length, into a service reservoir which has a capacity of 1,404,700 gallons, its top-water level being 287 feet above the sea. Clear water is then distributed to the city through a twenty-one inch main.

Almost as important as the various undertakings we have described are the mining industries undertaken by Americans. The oldest and most profitable of such mines are the gold mines at Wun-san which have been worked for eleven or twelve years. The American syndicate operating this, mine is called the Oriental Consolidated Mining Company which has a capital of 10,000,000 yen. Organized by James R. Morse of New York in the nineties, the company was incorporated under the laws of West Virginia. According to the report, the total output from the opening of the mine up to June 31 , I908, has amounted to $\$ 10,701,157$, and the output during the seven months, ended February I, I909, reached \$I ,7 I6, I04 in gross value, or $\$ 1,421,213$ in net value. The company pays to the Korean government an annual royalty of 25,000 yen. At the end of December, 1908, the company 
employed, in addition to seventy-five Americans and Europeans serving as superintendents or foremen, sixty Japanese, who were skilled laborers, 2,300 Koreans, and 600 Chinese, all unskilled.

Other mines operated by Americans are, in the order of importance, as follows :

I. The Su-an gold mines, which originally belonged to British concessionaires, were leased to the Collbran and Bostwick Development Company in February, I908. The American firm has installed stamp mills, and prosperous business is promised.

2. The Chiksan gold mines are owned by an American-Japanese concern, but their operation is under American management. Some twenty-four Americans are employed as superintendents and foremen. In addition to the ores already opened an extensive deposit has lately been found.

3. The Kapsan copper mines had, before they were handed over to Collbran and Bostwick, been worked by Koreans in a most primitive fashion, and for nearly a thousand years supplied almost all the copper consumed in Korea.

4. A few years ago an American discovered a graphite ore not far from Seoul. It was the first graphite ore ever found in Korea. A brief experiment, however, disclosed that this mine was not of much value. A more promising mine was later found on the east coast of Korea, containing graphite of superior quality.

Of the above enumerated mines, the Kapsan copper mine has an interesting history which requires a brief consideration by reason of the fact that the disputes over the mine between the Japanese residency-general and the Collbran and Bostwick Development Company have 
furnished foreign critics with a pretext to asperse Japan's attitude towards foreign interests in Korea. The concession to exploit this copper mine was granted to Collbran and Bostwick by the Korean emperor when the RussoJapanese war had just begun. When Japan became the mistress of the peninsula, the residency-general on behalf of the Korean government refused to confirm this concession on the ground that it was granted neither through the proper channel nor in appropriate form to make it legally binding. The litigation that ensued lasted three years and ended only in the summer of 1908, in a manner, it is true, perfectly satisfactory to the American firm. It was deplorable, to be sure, that the decision was delayed so long, yet it is hardly fair to attribute this delay to any sinister design on the part of Japan. Japan was no doubt desirous of promoting by all legitimate means the interest of her own nationals, but to say that she contrived virtually to close the "open door" by subterfuge and chicanery is a malignant slander which can emanate only from jealous or embittered minds. The prolongation of the contention was caused by the necessity of examining voluminous records and of investigating other complicated matters in connection with the case.

While the Kapsan case was in dispute, Collbran and Bostwick were not inclined to compliment the Japanese, and it is but natural that views on this matter based upon the information obtained from the firm in that period of suspense should be extremely gloomy and unfavorable to Japan. This statement should not be construed as a reflection upon the American concessionaires' sincerity. They would not have been human if they had acquiesced in the situation without complaint, and 
no one should hesitate to express unreserved sympathy for them in their ill-luck in having had to carry on so protracted a litigation. With this in view it is refreshing to note that when the Kapsan case was brought to a happy issue on June I5, 1908, Messrs. Collbran and Bostwick made a public statement whose dignity and graciousness were calculated to add much to their credit. In this statement which was cabled to the American press Messrs. Collbran and Bostwick said that " Prince Ito has made good his assurance of extending full support and generous treatment, once he was convinced of the merit of every claim presented for his consideration;" that " the new conditions will comprise such permanent security of title as will satisfy the most exacting American or European lawyer ; " and that " as Korea is known to be a well mineralized country, it is certain that the revised and favorable mining regulations, which will provide perfect protection and security, will attract experienced mining capital."

Since this statement was made the Korean mining laws have been revised in a manner satisfactory to all concessionaires and prospectors. Nor was this all that was done by the residency-general for the exploitation of mining resources in Korea. The Japanese administration induced the Korean government to extend to all mining concerns, irrespective of nationality, the privilege of importing free of duty all machinery and materials to be used for mining purposes-a privilege which until then had been enjoyed only under special concessions granted to a few foreign concerns. Still another measure taken by the residency-general for the encouragement of mining industries in Korea was the addition of copper to the list of minerals which are exempt from export duty-an 
immunity which had been applied only to gold and silver.

A part from such legislation, foreign concerns, operating various mines in Korea, have been materially benefited by the extension to their mining districts of postal and telegraph facilities, and the installation of police stations necessary to maintain order among mining laborers. Under the old Korean régime could any foreigner dream of enjoying such facilities and protection?

The significance of these new measures, it must be emphasized, lies not so much in their own merits as in the indication they afford of Japan's true intentions and policies. As a Japanese subject I would be accused of immodesty were I to laud these intentions and policies, yet if one looks at them without bias one is forced to ad. mit that they have not strayed far from the path of " fair play and a square deal," which is the watchword of those critics who would make it appear that Japan is the most self-seeking, the most unreasonable, and the most tricky nation that has ever existed. Indeed it is more amusing than provoking to see these critics lay their hands upon all sorts of missiles with which to assail the Japanese. They even have had the audacity to invent stories where material is lacking to belittle Japan. To cite an instance, a prominent American author on the Far Eastern question, championing the cause of Collbran and Bostwick (Collbran and Bostick he mistakenly calls the firm) in the above described Kapsan case, writes :

" Japan's secret service men in America and England were employed to scrutinize the past of Messrs. Collbran and Bostick to discover, if possible, something injurious to their character which might be used against them in 
the matter. Employees of the Japanese Legation at Washington circulated reports, taking pains that they would reach the State Department, that Messrs. Collbran and Bostick are adventurers who managed by fraudulent means to get some valuable concessions in Korea, and which they are now trying to blackmail the Japanese into purchasing from them at an exorbitant price."

One cannot be indignant at such delightful little fairy tales. Yet they no doubt admirably serve the purpose for which they are invented, for an unsophisticated public believes them with all the avidity with which the little children listen to stories about Cinderella or Jack the Giant Killer. True, Japan had to take great pains in investigating into the validity of the Kapsan claim of Collbran and Bostwick for the reason that under the old régime many concessions and privileges were obtained by doubtful means. For who can deny that Korea, with its corrupt court and its venal officials, was the paradise of concession-hunters, adventurers, and speculators? If the censors of Japan are reluctant to believe this statement because it comes from a Japanese, note the following passage from the Hon. George N. Curzon's " Problems of the Far East":

"A royal figurehead, enveloped in the mystery of the palace and the harem, surrounded by concentric rings of eunuchs, ministers of state, officials and retainers, and rendered almost intangible by the predominant atmosphere of intrigue; a hierarchy of office-hunters and officeseekers, who are leeches in the thinnest disguise; a feeble and insignificant army; an impecunious exchequer, a debased currency, and an impoverished people-these are the invariable symptoms of the fast vanishing regime of the older and unredeemed Oriental type. Add to these 
the first swarming of the flock of foreign practitioners, who scent the enfeebled constitution from afar, and from the four winds of heaven come pressing their pharmacopœia of loans, concessions, banks, mints, factories, and all the recognized machinery for filling Western purses at the expense of Eastern pockets, and you have a fair picture of Korea as she stands after ten years of emergence from her long seclusion and enjoyment of the intercourse of the nations."

The reiteration and corroboration of such views can be found in not a few books and articles in various languages. To make the situation still worse the corrupt entourages of the emperor were always on the alert to utilize every opportunity to line their pockets by acting as intermediaries between their master and foreign promoters. Let me tell you a story for Mr. Collbran. When the Collbran and Bostwick Development Company was organized some years ago, Mr. Yi Wan-yong and three other Korean gentlemen advised the ex-emperor to buy some of the company's shares, as the electric enterprises in Seoul, they pleaded, would yield great profit in the near future. They succeeded in inducing His Majesty to pay over the sums of 500,000 yen and 700,000 yen on two occasions. The greater portion of this money, however, appears to have been misappropriated by the four gentlemen above referred to, so that what had been received by the company was only the remaining trifle. In the meantime the electric enterprise has proved a great success, and the ex-emperor naturally expected the dividend of the company in due proportion to the money paid over. But the dividend was very small. On inquiry it was found that the four gentlemen were guilty of fraud. They had the audacity to forge an imperial receipt, in which the square 
seal of the reigning sovereign, instead of the octagonal one of the retired emperor, was used.

In such atmosphere of mendacity and peculation is it not natural that the Japanese administration, committed to the protection of Korean interest and welfare, should be on its guard when claims, secured in the old era of corruption, are presented for its confirmation? And in fairness it must be recognized that the same precaution has been employed with regard to Japanese claims. The case of the so-called Nagamori land scheme affords ample vindication of this impartial attitude of the Japanese administration.

This land scheme was broached by a bold Japanese speculator by the name of Nagamori, who, taking advantage of the chaotic state on the peninsula incident to the war with Russia, persuaded the Korean ruler to grant him a gigantic concession, authorizing him to redeem all the waste lands in the country. The plan was matured so surreptitiously that even the Japanese authorities had little knowledge of it until its originator made it known to them with a view to securing their assistance in its execution. In its inception the project was not necessarily objectionable, inasmuch as there was an immense area of fallow land, which ought to be brought under the plough. But, however harmless and even good the intentions of its originator might have been, it was evident that the proposal was ill-timed, for Japan was obligated to devote all her energies to the internal reform of Korea before embarking upon any undertaking of its nature, and it was most fortunate that as soon as the Japanese press raised a hue and cry against the scheme the Tokio administration forced Nagamori to relinquish the claim. 
There are minor cases wherein the Japanese authorities exercised their influence to prevent the realization of schemes of questionable nature with which Japanese subjects were identified; but the above-described case must serve. In the following chapter I shall elucidate my views on the question of the " open door" in Korea. 


\section{XVI}

\section{AMERICAN TRADE IN KOREA AND THE “OPEN DOOR"}

T $\mathrm{N}$ the previous chapter I have described the predominating position which American interest occupies 1 in Korea. In no other Far-Eastern country has the United States gained so firm a foothold as in that country. Dr. Horace N. Allen, writing admiringly of this unique position attained by American interests, says :

"To those who had made the trip by way of the Suez Canal and had visited that wonderful belt of commercial colonies under British rule, the sight of which makes the British blood in American veins tingle with pride, this condition of affairs in Korea was particularly impressive. While the American elements and American interests were something of a negligible quantity in the bustling marts that mark Britain's progress from Egypt through the Indian Ocean and the China seas; in Korea everything seemed to be American and our influence to predominate, quite reversing the situation as compared with the foreign settlements of the Far East."

Yet in the same breath Dr. Allen voices the apprehension that this agreeable sensation will not be experienced by Americans who may chance to visit Korea hereafter. Under Japanese rule there will, he seems to believe, be a wholesale discrimination against foreign interests in the peninsula, and the much-heralded "open door" will become the merest sham. To him it appears that when the Washington administration definitely 
recognized Japanese suzerainty in Korea, it practically abandoned all the advantageous position which had been acquired by the initiative and enterprise of American citizens.

It is not difficult to understand why Dr. Allen criticizes the Japanese advance in Korea in so gloomy terms, when it is remembered that not only did his long residence among the Koreans make him extremely sympathetic towards them, but his influence was the principal factor in the acquisition of American influence in Korea. And yet we can hardly share his views on the effects of Japanese rule upon American economic interest unless we fly in the face of indisputable facts. While it is not given to Japan to sacrifice her own interest in order to promote that of other nations, her methods in competing with Western nations will always be legitimate, and it is up to America to enter the arena with the manly determination which has characterized her past career, and face the new combatant without complaints and lamentations. Japanese capital may seek to buy up American enterprises, as it has done in the case of the Seoul electric trolley line, but that would simply be a case of give and take, and if the terms offered are not acceptable the Americans are under no obligation to sell. Ask Messrs. Collbran and Bostwick whether they sold the trolley line in Seoul under agreeable circumstances and on satisfactory conditions, and they will not hesitate to answer in the affirmative. Inquire also whether there is any occasion for apprehension as to the future of the American mining concerns in Korea, and you will readily discover that not a fleeting shadow is cast over their bright prospect. The metals produced are purchased by the Japanese almost on the spot, thus doing away with the trouble of shipping 
them to distant countries, and the mine owners all bear testimony to the satisfactory state of their transactions with the Japanese buyers. To say, then, that Japan means to reserve Korea for her own development at the expense of other trading nations interested in that country, is not to represent the situation in the true light. To drive this home to the reader it is necessary to review the foreign trade of Korea with special reference to America's share in it.

I have said that of the Western nations trading with Korea America ranks next only to England in the import trade of the country, but when Asiatic nations are taken into consideration she occupies the fourth place: Japan comes first, China second, England and the United States following in the order named. On the other hand when we compare the progress of American trade in Korea during the past several years with that of the other three countries, we find Japan, China, and Great Britain lagging far behind the United States. In 1903 the total amount of import from America was only $398,377 y e n$, and it is a most remarkable fact that after the lapse of five years the amount of American trade has increased almost eleven times, while British and Japanese trade has increased eight times and twice, respectively. Import trade from China has been declining rather than increasing. It certainly bespeaks the sagacity and energy of American traders that while Japan, enjoying all the advantages afforded by her favorable geographical position, the large number of her nationals residing in Korea, and many another circumstance, could only double her export to Korea, American export to the country has increased eleven-fold. The following table shows the growth of import trade from America, 1903 to 1908, 
as compared with that from Japan during the same period:

$\begin{array}{ccc}\text { Year } & \begin{array}{c}\text { Import from America } \\ \text { Value in yen }\end{array} & \begin{array}{c}\text { Import from Japan } \\ \text { Value in yen }\end{array} \\ \text { 1901 } & 398,377 & 11,554,969 \\ 1904 & 1,813,115 & 19,007,287 \\ 1905 & 1,978,812 & 23,561,899 \\ 1906 & 2,557,511 & 23,914,154 \\ 1907 & 3,295,558 & 27,363,872 \\ 1908 & 4,194,529 & 24,038,458\end{array}$

Again if we compare import trade from America to Korea for 1908 with that from other principal trading nations, we obtain the following table:

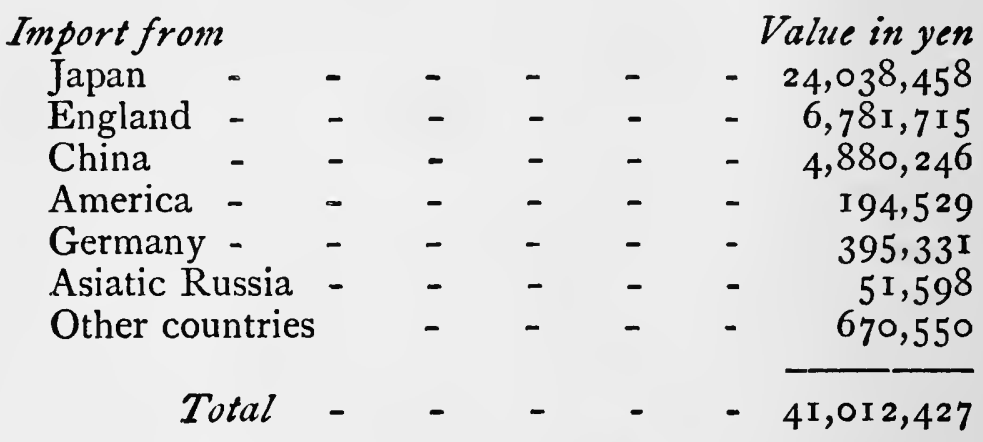

It will be seen that fifty-eight per cent. of the import trade of Korea was contributed by Japan, while England participated in it to the extent of sixteen per cent. Import from China amounted to eleven per cent., and that from America ten per cent.

While import from Japan was so large as fifty-eight per cent. of the entire import of Korea, it must be borne in mind that Korean goods were exported to the Mikado's Empire to the extent of $10,424,560$ yen, which is equivalent to seventy-seven per cent. of the total export trade of the peninsula. As against this enormous purchase 
made by Japan, America participated in the export trade of Korea in 1908 to the extent of only 44,01 7 yen, while in the preceding year she bought practically nothing. In the following table America's part in the export trade of Korea, during the five years from 1904 to 1908 , is compared with that of Japan:

\begin{tabular}{|c|c|c|c|}
\hline Year & $\begin{array}{l}\text { Export to } A m \\
\text { Value in } y\end{array}$ & & $\begin{array}{l}\text { Export to Japan } \\
\text { Value in yen }\end{array}$ \\
\hline 604 & 0 & & $5,697,37 \mathrm{I}$ \\
\hline & o & & $I_{4}$ \\
\hline & 225 & & $6,916,848$ \\
\hline & o & & I $2,649,267$ \\
\hline & 44,017 & & - $\quad 10,424,560$ \\
\hline
\end{tabular}

Under ordinary circumstances a country becomes a good customer of the nation which is a liberal purchaser of her produce. This point I have already discussed in the chapter on Japan's commercial advance in Manchuria, and it is only natural that Japan, ranking first in the export trade of Korea, should also rank first in its import trade. And yet Japan's export to Korea has increased less than one-fifth as rapidly as that of America, whose purchase of Korean products is almost nil.

In examining the statistics pertaining to American export to Korea, one thing challenges our particular attention, i.e., that American trade began to forge ahead as soon as Japan occupied the peninsula. Prior to the establishment of the Japanese protectorate American export to Korea was rather insignificant, that for 1903 having amounted to only 398,377 yen. But early in 1904 the island empire became the mistress of the peninsula, and American export to Korea suddenly swelled to I,8 I 3, I I 5 yen. This phenomenon cannot be regarded as a mere coincidence, for the statistics clearly indicate that the 
sudden augmentation of American trade was due to Japanese demand for American goods. Since I904 the progress of American export to Korea has been both steady and rapid. In the face of these facts who can say that Japanese rule in Korea is inimical to the "open door," and consequently to American interests? It is time that the advocates of America's commercial expansion in the Far East should pause and think whether their cause will be served by indulging in sentimentalities and platitudes at the expense of Japan's reputation.

The chief imports from America are railway materials, kerosene-oil, and flour. In these three articles America is almost monopolizing the market. While American cigarettes, lumber, cement, nails, sheetings, and salt fish are imported to a considerable extent, these have formidable rivals in Japanese, British, and, in a few cases, Chinese goods. In 1908 American flour imported to Korea amounted in value to 372,8 I 6 yen as against I I,475 yen of Japanese flour. American kerosene-oil was imported to the extent of I,369,99 I yen, while Russian and Lankat oils imported amounted to only 20,409 yen and 50,000 yen, respectively. As the tables above presented clearly indicate, America's most formidable competitors are Japan and England. China, too, has a greater share in the import trade of Korea than does America, but the Chinese goods, with the exception of lumber and salt fish, are of such nature as does not infringe upon America's field. True, statistics show that in 1908 Chinese cigarettes imported to Korea amounted in value to so much as I76,0 I0 yen as against 48,501 yen from America, but the cigarettes from China are mostly manufactured at the Shanghai and Mukden factories of the American-British Tobacco Trust. This Anglo-Amer- 
ican concern is so important a factor in the tobacco trade of Korea that it requires more than a passing note, but before entering into its description let us study the following table which shows where America feels the competition of Japan and England keenly:

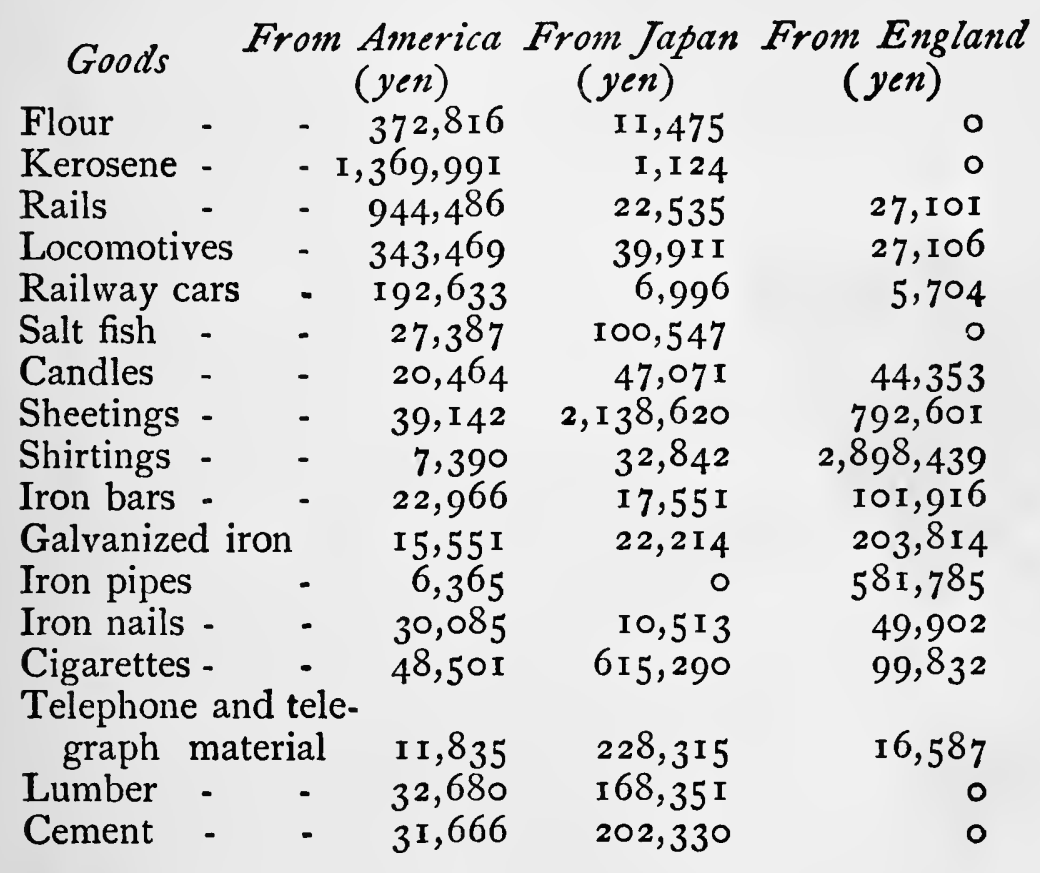

It will be seen that in salt fish, sheetings, shirtings, candles, galvanized iron, cigarettes, telephonic and telegraphic materials America finds strong rivals in Japan and England. Again, American trade in iron pipes and iron nails falls far behind that of England, while more lumber and cement are imported from Japan than from America.

It has been noted that the total amount of import from America in 1908 was 4,194,529 yen. This, however, does not include import from Hawaii and the Philippines. The importation of refined sugar from Hawaii and the Philippines was commenced in 1908, the amount im- 
ported in that year being 270,000 pounds. Cigarettes were also imported in that year from the Philippines, with the result that the total amount of American tobacco imported in 1908 showed an increase of 60,000 yen as compared with that for the preceding year. Including other articles imported, Hawaii and the Philippines participated in the import trade of Korea to the extent of 23,274 yen and 66,925 yen, respectively, making the grand total of American export to Korea in 1908 4,284,728 yen.

Now we must enter into details of the tobacco trade in Korea with special reference to the activities of the American-British Tobacco Trust, for the competition in this particular field between the trust and the Japanese tobacco monopoly has been, and will continue to be, keen. It is estimated that Korea consumes $840,000,000$ cigarettes annually, about 40,000,000 being contributed monthly by Japan. The remainder are composed largely of Virginia leaf tobacco and are manufactured mostly at Shanghai, and also in the United States and England. According to the report of Mr. Thomas Sammons, American consul-general at Seoul, the American-British trust already has over forty per cent. of the total cigarette business of Korea. It has also been stated in a previous chapter that the trust has over fifty per cent. of the entire Manchurian import trade, and controls the great bulk of all the business of the Orient in this particular line outside of Japan. What business success this Occidental company has gained in the Far East is largely due to its energetic business methods and its system of carrying stocks in the field of its commercial operations. The company has in the Oriental field a staff of active, able American and British salesmen, many of whom speak 
the native language, and under whom many native salesmen are employed. In introducing goods among the natives suitable advertisements such as posters or dodgers are freely utilized and sample packets of cigarettes are generously distributed. Where retailers are not anxious or willing to push sales, hawkers are employed to drum up trade. A printing plant is maintained in Shanghai, where up-to-date American color presses are used to prepare advertising matter with the text in native characters as well as pictures designed to suit local conditions.

There are two kinds of cigarettes used in Korea, one with mouthpiece attachment, the other without. About forty-five per cent. of the Korean cigarette trade is in the mouthpiece, or Russian variety, of which the Japanese tobacco monopoly supplies more than ninety per cent. Much hand labor is necessary in the production of these cigarettes, but the trust, after a careful investigation, promises to manufacture by machinery cigarettes with mouthpiece attachment. Should this new departure prove successful the trust is bound to become a strong competitor in the market heretofore monopolized by the Japanese.

The remaining fifty-five per cent. of the trade is in the cigarettes without mouthpiece attachment, and it is in this field that the American-British tobacco interests occupy a dominant position. The Japanese monopoly supplies only fifteen per cent. of this variety, the remaining forty per cent. being almost entirely contributed by the American managers of the American-British company.

Turning to Japan's tactics in competing with the American-British company, we are informed that where competition is keenest the Monopoly Bureau sells goods 
at cost price to the Oriental Tobacco Company, which is the sole agency for Japanese cigarettes. The monopoly regulations, however, forbid the sale of tobacco at less than cost price under any circumstances. It is believed that tobacco factories on a large scale will be established both in Korea and in Manchuria. The fact that the importation of Japanese cigarettes into Korea has been so great is principally due to the large number of Japanese residing in the country, but it is not believed, as ConsulGeneral Sammons says, that their attachment to Japanesemade cigarettes will prove unalterable, regardless of price or quality.

While American trade in Korea has made phenomenal progress there is much room which can be exploited for its further advancement. American boots and shoes, watches, rubber and elastic goods, refrigerators, hardware, hats and caps would find in Korea a limited but increasing market. But the handicap in doing any direct business with America is that the American exporter usually demands spot cash against documents in America; consequently the loss of interest resulting from this method, coupled with the uncertainty as to when the goods will actually arrive there, is so great that the merchants prefer to pay higher prices even for inferior goods and get them from Japan. It takes from three to nine months from the date of ordering to get the goods to Korea. Cash must accompany small orders, and as interest rates are as high as ten to twenty-four per cent. per annum, and even higher in some instances, transactions of this kind are not inviting. In addition to these unfavorable circumstances such American merchandise as boots and shoes have to contend with the disadvantages arising from the absence of retail stores that could 
handle American-made boots and shoes, although there is an increasing demand for these articles. Set this over against thousands, and even tens of thousands, of Japanese retail stores distributed throughout the country, and you have another reason why Japan has far and away the largest share in the import trade of Korea. It seems obvious that a practical suggestion for removing the above-described impediments in the way of America's commercial development in Korea would render American interests infinitely greater service than a hundred volumes of books censuring, in many instances upon flimsy authorities, Japan's methods of pushing her commercial interest in the peninsula. 


\section{XVII}

\section{AMERICAN MISSIONARIES IN KOREA}

INCE the inauguration of the Japanese protectorate in Korea the unfriendly attitude assumed by some 1 of the foreign missionaries towards Japan has claimed the attention of both the Japanese authorities and press. Fortunately much of the misconception, which formerly existed in the minds of the missionaries with regard to the intentions of Japan, has been dispelled, thanks to the lenient policy of the latter. Yet a certain section of the Japanese press continues to voice misgivings and apprehensions. The assassination of Prince Ito by a Korean convert to Christianity was by some enterprising, though somewhat irresponsible, Japanese journals made an occasion to rekindle the smouldering embers of distrust into a flame which, for a while at least, cast a lurid glare over the evangelical workers in the erstwhile Hermit Kingdom. The assassin was a Roman Catholic convert, but to the average Japanese there is little difference between Protestantism and Roman Catholicism. Some journals went so far as to intimate that two Americans, one of them a missionary, had wittingly been engaged in stirring up anti-Japanese sentiment among the masses of the Korean population, an agitation which was indirectly responsible for the Harbin tragedy enacted by the Korean fanatic. Such insinuations can only recoil upon those who make them, and it 266 
was only natural that they should have been silenced by the saner views of the majority of the Japanese press. At the same time it is to be regretted that, while many of the missionaries are unbiased and fair in their attitude towards the new régime, there are a few prone to form hasty conclusions and indulge in unwarranted criticism. The acts of the latter class of missionaries have been partly responsible for the unkindly judgments which some Japanese papers have passed upon the heralds of the Gospel in Korea. Since 1908, the Christian missionaries in Korea have been unusually active, manifesting a determination to make Korea a Christian nation before many years. During 1909 they sold over 400,000 Testaments, Gospels, and other portions of Scripture as against 200,ooo in the previous year, and in the current year they are resolved to increase the number of native converts to I, $, 00,000$, which is more than one-tenth of the entire Korean population.

Nowhere else in the world has Christianity spread so rapidly as in Korea. It was only in 1884 that Korea received the first Protestant missionary in the person of Dr. Horace N. Allen, an American physician, who was, as he himself said, given the task of opening the peninsula to Christianity at the point of a physician's lancet. The pioneer's work was admirably done, and within a quarter of a century Korea is able to boast of 250,144 converts, I,900 native pastors, 800 churches, fifteen mission hospitals, and 350 missionary schools with 15,000 pupils. It is true that Roman Catholicism entered Korea as early as the middle of the seventeenth century; but in 1866 Prince Tai-wun, father and regent of the retired emperor, ordered the wholesale slaughter of all the converts to Christianity. The real beginning of Christianity in 
Korea, therefore, dates from I884, two years after America secured the first treaty which the Land of the Morning Calm had ever made with any Western nation, and which removed the ban put on the propagation of the Gospel.

Almost simultaneously with the advent of American missionaries, English missionaries also appeared in the field, to be followed by those from France, Germany, Russia, Australia, and Canada. At present the principal missionary societies represented in Korea are the Methodist and Presbyterian Churches in the United States, the Australian and Canadian Presbyterian Churches, and the Society for the Propagation of the Gospel of the Anglican Church. Add to these the Catholic Churches in Germany and France, and the Greek Orthodox Churches in Russia, and the list is wellnigh complete. The various Protestant Churches are bound together with an admirable spirit of coöperation, while all the Presbyterian Churches have united in one presbytery. According to the latest statistics the foreign population of Korea, excluding Japanese and Chinese, numbers 757 , of which 315 were missionaries. As the number of native population is estimated at 9,78I,67I it appears that there is one missionary to every 31,053 Koreans. Set this over against one missionary per 63,000 persons in Japan, and you can readily understand how great an influence the missionaries exercise in Korea. The following table shows the nationalities of the missionaries in Korea, and affords some idea of the respective strength of the Protestant, Catholic, and Greek Orthodox Churches : 
America

\section{Presbyterian}

Methodist

Adventist

Y. M. C. A.

England

Anglican

Bible Society

Canada

Salvation Army

Australia

France

Presbyterian

Presbyterian

Germany

Catholic

Russia

Catholic

Greek Orthodox
No. missionaries

101
78
5
6

24

3

14

I3

57

2

Total. . . . . . . $\overline{3^{15}}$

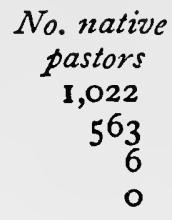

$3^{I}$

7

43

23

63

- unknown

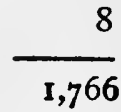

No. native converts 148,780 28,017 unknown unknown

4,435
unknown
300

3,830

75

61,290

unknown

246,727

A glance at these figures reveals to us that America has by far the greatest share in the evangelical work in Korea. Of the 315 missionaries now resident in Korea 190 are Americans, while of 248,493 , constituting the entire body of native Christians, I 78,387 were proselytized through the influence of American missionaries. With these figures before us it is not difficult to understand why America is seriously concerned with the missionary question in Korea.

The reason for the remarkable success which the American missionaries have achieved in Korea is not far to seek. In the first place, the American missionary has consistently followed a lenient and catholic policy in dealing with the natives who flock to the Christian standard, allowing them autonomy to a certain extent in the management of churches and schools. He teaches fundamental principles and points out the path which he thinks the natives should follow, but he has the wisdom 
to refrain from interfering with them in such matters as are not essential to the propagation of the Gospel. He does not insist upon conducting everything in accord with his own conception of civilization, but pays due respect to the customs and usages which form the woof and warp of the native institutions. For instance, American missionaries have established boys' schools separately from girls', as the Koreans, like the Chinese, have prejudice against the mingling of the two sexes in public. So also they have avoided housing men's hospitals in the same buildings as those for women. In schools and churches pupils and congregations are not required to sit on chairs, but are allowed to sit on the floor after the Korean fashion. Perhaps the Rev. Ernest F. Hall, of the Presbyterian mission in Korea, expresses this tactful policy of the American missionaries most adequately when he says :

" Every nation must eventually evangelize its own people. It is not the purpose of the foreign missionary enterprise to place Americans as pastors over the churches in foreign lands. The missionary is a superintendent of various forms of work, educational, evangelistic, medical, and literary. $\mathrm{He}$ is teaching them the principles of the Christian religion and training native leaders who shall in turn be preachers and leaders of others. . . . The Oriental and Occidental minds and modes of life are very different. The basic principles of Christianity are the same. The way in which the Church shall express those principles and work them out in practical life will differ in different lands. Hence the desire to establish a church in Korea which, while it shall be Christian, shall be so adapted as to accomplish the work of Christianizing the whole land and of giving the people the opportunity 
to express themselves in work and in worship in a manner best suited to their own ideals and modes of thoughts."

The second cause of the American missionary's success lies in the ample knowledge he possesses of the Korean language. Either in preaching or in teaching he uses the vernacular with remarkable fluency. In every-day intercourse with the natives he can freely communicate his thoughts, which goes a long way towards the winning of the confidence of the Koreans. When a missionary newly arrives in Korea from America, it is the rule not to assign to him any fixed position for at least three years, but to require him to devote his best energies to the study of the Korean language. Compare this with the case of Japanese judges, who administer justice through Japanese or Korean interpreters that are not always honest, or that of Japanese teachers attempting to impart complicated knowledge to Korean youths also with the assistance of interpreters, some of whom are deplorably incompetent! Surely Japan must learn a lesson from the method of American missionaries if she is successfully to carry out the great task which she has undertaken in behalf of Korea.

The presence in Korea of so large a number of foreign missionaries, assuming an unfriendly, if not hostile, attitude towards the advent of Japanese rule created a situation which demanded serious attention on the part of the Japanese authorities. True to the national policy of religious tolerance which she had consistently adhered to since the opening of her doors to foreign intercourse, Japan decided not only to allow the foreign missionaries in Korea unrestricted freedom of religious propaganda, but to make them her virtual co-workers in the grand 
undertaking of the regeneration of Korea. At the same time, however, the missionaries were given to understand that Japan would not connive at the acts of those, who, under guise of spiritual work, would not scruple to instigate the natives to oppose Japanese measures. That this precaution on the part of Japan was not altogether superfluous must be admitted, for some of the missionaries did not stop to think that the time had come when Korea had to be subject to the influence of either Japan or Russia, and that under Japan at least there would be religious liberty with the fullest possible freedom to carry on the work of evangelization. Let us be far from imputing sinister motives to the acts of such missionaries: we admit that they were moved by a natural feeling of sympathy for those among whom they were laboring, and considered it their duty to take sides against Japan. It was an open secret that those natives, who were engaged in sedition and conspiracy against the Japanese protectorate, were at one time or another under missionary influence, and made Christian churches and schools their rallying points as well as their havens of retreat. It might have been that the missionaries themselves never indorsed such unscrupulous acts of the native converts; yet the fact remains that the agitation of these ill-advised followers of Christianity proved no small obstacle to the execution of the reform measures mapped out by Japan.

Perhaps the plainest explanation of Japan's fundamental religious policy in Korea is found in the following statement made by no less a personage than Prince Ito in September, 1907, at the request of the Tokio representative of the Associated Press: "So long as the missionary moves along his own road, attends to his own business, and permits me to move along my own road and attend 
to my own business, there shall be no interference with the work of the missionary by me or by any of those whom I control; but if the missionary shall step aside and cross the path I am on and obstruct that way, there can be but one result-I cannot be expected to give way." This principle is in harmony with the views of the majority of the Korean missionaries, who believe it their mission to establish the kingdom of God which shall rule within the hearts of the Koreans, and not to determine whether Korea shall rule herself or whether she shall be controlled by another nation. This fundamental policy the veteran statesman expounded whenever occasion presented. It was his conviction that without judicious, efficient government, Korea could not reap the full benefit which the noble efforts of the missionaries ought to bestow upon her. On the other hand, he was also convinced that, alienated from sound religion, which is the corner-stone of true civilization, civil government, however efficient in itself, would find it difficult to breathe life and energy into a nation which had been decrepit for many centuries. In the harmonious coöperation of these two great institutions, sound religion and honest government, each working out its own great purposes without interfering with or infringing upon the rights and responsibilities of the other-in this alone Ito believed lay the hope of Korea's salvation.

Acting upon this conviction Ito persuaded the Korean government to subscribe 10,000 yen towards the building fund of the Y. M. C. A. in Seoul. It was also through his influence that the crown prince was induced to lay the corner-stone of the building-an event which encouraged the native Christians as well as their foreign spiritual teachers. Over the main entrance to the build- 
ing one notices carved on a block of granite an inscription by the hand of the crown prince himself, which remains a public memorial of the interest taken by the Imperial House in the erection of the building. When delegates came from every quarter of the world to attend the opening exercises of the building, Prince Ito tendered a banquet in their honor, and addressed them as follows : "In the early years of Japan's reformation the senior statesmen were opposed to religious toleration, especially because of distrust of Christianity. But I fought vehemently for freedom of religious belief and propaganda, and finally triumphed. My reasoning was this: Civilization depends upon morality, and the highest morality upon religion. Therefore religion must be tolerated and encouraged. It is for the same reason that I welcome the Young Men's Christian Association, believing that it is a powerful ally in the great task I have undertaken in attempting to put the feet of Korea upon the pathway of true civilization."

This is the key-note of Ito's religious policy in Korea. So zealously did he observe this principle that when $\mathrm{Mr}$. Song, Korean Minister of Home Affairs, made indiscreet remarks about the foreign missionaries in Korea, he did not hesitate to dismiss him. The Korean statesman's remarks were to the following effect: "The most serious question now before us relates to the native Christians, whose affiliations are of a questionable nature. They are united in the common object of opposing the present administration, and are conspiring to undermine it. The fact that they are backed by a group of American missionaries makes the question extremely delicate; but once they take up arms in insurrection, I shall not hesitate a moment to adopt drastic measures." In order 
to allay the uneasiness which was naturally caused by such imprudent utterances, Prince Ito made public a letter which he addressed to the American ambassador at Tokio on the question. From this letter the following passage is quoted as it serves to explain Japan's attitude towards the native Christians and foreign missionaries :

"During the Korean emperor's recent trip to the northern and southern parts of Korea, I met a number of missionaries at Ping-yang, and had an opportunity to ascertain that they not only take no steps whatever in opposition to the administration of the Korean government, but are in sympathy with the new régime and are endeavoring to interpret to the Korean people the true purpose of that régime. I am personally acquainted with many American missionaries in Seoul, with whose conduct and views I am fully familiar. The fact that they are in sympathy with the new régime in Korea which is under the guidance of the residency-general, and that they, in coöperation with the residency-general, are endeavoring to enlighten the Korean people, does not, I trust, require any special confirmation. . . . I may also state that the Christians in Korea will continue to receive equal treatment with other subjects, and will be dealt with only in case of distinct violation of the laws of the country. . . . It may also be stated that among the many Korean Christians not a few are attempting to make use of that religion for inspiring the idea of independence. This fact cannot be regarded as due to the instigation of the American missionaries, . . . and I wish to make this explanation of the matter on behalf of the American missionaries in Korea."

The repeated avowal of Japan's catholic policy towards Christianity and its frequent vindication cannot fail to 
convince even the most skeptical of the sincerity of her intentions, and it is but natural that the American missionaries in Korea are now willing to coöperate with the Japanese authorities. For this signal change of the American missionaries' attitude the judicious policy of the Roosevelt administration was as much instrumental as the tolerance of Japan. In the early stage of the Japanese occupation of Korea some missionaries earnestly believed that the United States was going to interfere with Japan, and a great number of Koreans, lured by the same chimerical idea, rallied to the Christian mission churches. But Washington knew its business better than did the missionaries. Not only did it not encourage those missionaries who would see the new order of things subverted, but it repeatedly told them to " refrain from any expression of opinion, or from giving advice, concerning the internal management of the country, or from intermeddling in political questions." To carry out this policy of the Washington government no one perhaps was better adapted than Mr. Sammons, then American consui-general at Seoul. A man of genial temperament and sympathetic nature, the consulgeneral was extremely popular throughout Korea, and his sane counsel was of great influence in converting those of his compatriots who had been inclined to assume hostile attitude towards the Japanese administration. During some two years of his incumbency his position was one of extreme delicacy and difficulty, requiring assiduous toil and unwavering patience. Those clamorous missionaries who always had complaints of one nature or another actually overwhelmed him with appeals and requests, many of which were found not justifiable. Amid these protests and complaints Mr. Sammons stood 
firm, assuring the missionaries of the futility of the attempt to obstruct the Japanese advance, with the result that the unwise took second thought, and gradually learned that the Japanese were not quite so bad as they were thought to be.

There was one condition which the missionaries were especially reluctant to accept, and that was the Japanese proposal to put all the missionary schools directly under the regulations of the Korean government. The residency-general was prompted to adopt this measure by reason of the undoubted fact that in some quarters the Koreans were educated to oppose the Japanese protectorate. With this proposed step the climax of irritation was reached, some missionaries bitterly resenting the movement, and the Japanese intimating that the opposition on the part of the missionaries was evidence of the necessity of their control because it was evidence of enmity. But thanks to the unremitting toil of Mr. Sammons and to the sane counsel of Bishop Harris, of Dr. Heber Jones of Seoul, of Dr. Wells of Ping-yang, and some other broad-minded Christian workers, the difficulty was solved in a most satisfactory manner. In the agreement that ensued the missionaries agreed to register the mission schools as prescribed in the educational regulations of the government. In recognition of this concession the residency-general not only reasserted its fixed policy of not interfering with Christian religious teaching, but promised to coöperate with the missionaries in promoting the interests of Christian schools, extending to the graduates of such schools the same benefits and privileges as those enjoyed by the graduates of the government schools. That the missionaries are well pleased with this arrangement is indicated by the fact 
that as soon as the agreement was made they began to register their schools with the government, so that within a comparatively short time all the missionary schools will, it is expected, be under the "Regulation concerning Private Schools."

While the prospect of harmonious relations between the Japanese authorities and the missionaries in Korea is becoming brighter every day, still circumstances are not lacking which are liable to prove fresh causes of misunderstanding. The chief of such circumstances is the conduct of native Christians who, abusing the confidence placed in them by foreign missionaries, do not scruple to take such steps as would besmirch the names of their spiritual teachers. To cite an instance, a recent number of the journal published by the Presbyterian Church in Seoul contained an article in Korean under the caption of "Are the People of Great Korea not Desirous of Obtaining the Right of Independence?" which apparently was intended to arouse anti-Japanese sentiment among the natives. The article was written by a Korean and was published over his own signature, and Dr. Underwood, who was in the position to superintend the publication, was, it has been explained, wholly unaware of its contents. Yet the insertion of an article of such seditious nature in the organ of a religious body, which intends to coöperate with the Japanese authorities, is liable to cause fresh misgivings to an uninformed public, while credulous natives may derive from it hope which cannot be gratified.

Another cause of difficulty lies in the acts of those natives who profess to embrace Christianity only to abuse it in their scheme of evading the law. In a certain village in North Korea the inhabitants insisted that 
as Christians they were not bound by duty to pay taxes unless they were so instructed by their mission headquarters. They hoisted banners bearing the inscription of a cross, and attempted to mob the tax collectors out of the village. When the attention of the missionaries, who the rioters said were their religious teachers, was called to this performance, it transpired that the rioters were not Christians and had no relation whatever with any religious organization. Naturally the missionaries were greatly annoyed by this trickery, and approved due punishment of the culprits. It is, therefore, extremely dangerous to pass severe judgment on foreign missionaries upon the flimsy authority of dishonest natives.

On the other hand it must be admitted that some of the Japanese journals are responsible for the mischief done to the consolidation of friendly relationship between the missionaries and the Japanese people, for fortunately or unfortunately a section of the Japanese press has lately emulated the methods of American newspapers of extremely enterprising nature. Only recently the Hochi, a Tokio daily claiming to enjoy a very wide circulation, published an article declaring that if all the missionaries left Korea the happiness of the natives would be greatly enhanced. What an indiscreet, unwarranted statement when the Japanese government and the thoughtful class of its subjects are testifying to the good work done by the missionaries, and striving to remove all causes of irritation with regard to the religious question in Korea!

Last but not least, the indiscreet acts of some missionaries are as reprehensible as the sensational utterances of thoughtless newspapers. I would be the last man to 
deny that, as a rule, American missionaries are possessed of sound common sense as well as superior mental qualities. Yet now and then we come across missionaries whose lack of wisdom causes much trouble to their fellows. Several years ago there was one missionary from America whose quick temper bordered upon insanity. This man, while a guest at a Buddhist temple, lost his patience and began smashing the little plaster idols with his cane. For some time after this awkward incident the priest declined to admit any missionary to the sacred precincts. The case created a sensation at the time as the British representative at Seoul urged drastic measures in punishment on the ground that his government would never allow any interference with the native worship in India. This intemperate missionary, rebuked by the American minister, gave a promise of decent behavior, but it was not long before he forgot the promise and wrote a letter to the Korean emperor calling upon him to repent of his sins and asking to be allowed to preach repentance to him. This letter, written by an ignorant native scribe, was full of derogatory terms, and the matter was naturally referred to the American minister, who was again obliged to admonish the missionary.

To be sure, such a flagrant case of indecency is an isolated one; yet it cannot fail to prejudice the natives against the entire body of missionaries. It is needless to enumerate less notorious cases, but the following passage from Dr. Horace N. Allen's “Things Korean" bears testimony to the presence of not a few missionaries who make themselves unnecessarily obtrusive :

"There were some missionaries for whom it was always a pleasure to work. They only came for assistance when 
they had meritorious cases well supported by the necessary evidence. Others were inclined to rush to the legation or consulate on the slightest pretext and their calls were dreaded, since one never wishes to appear unsympathetic or disobliging. Yet it was most distressing to be continually obliged to intrude some petty missionary case of emergency into delicate negotiations of a more or less serious nature."

It must not be presumed that Japan is unwilling to hear the missionaries criticize her methods in Korea. Sensitive as we are, we are not so narrow-minded as to close our ears to sound criticisms, much less so arrogant as to hurl defiance at them. There must, however, be a clear line of demarcation between malicious criticism and criticism that springs from genuine sympathy and good wishes for the success of the Japanese administration. It is the former class of criticism which Japan is ill-disposed to heed; but sympathetic criticism, even when expressed in vigorous terms, will always be welcomed by her. It is not because the missionaries are critical that the Japanese administration has at one time been apprehensive of their activities, but because their criticisms seemed in many cases far from well-meaning. 



\section{B OOK III}

The Immigration Question 



\section{XVIII}

\section{JAPANESE IMMIGRATION BEFORE THE EXCLUSION AGREEMENT}

T $\mathrm{N}$ the summer of 1907 , the governments of Japan and the United States entered into an understand1 ing with a view to prohibiting the immigration of Japanese laborers into the United States. How this measure was forced upon the Roosevelt administration, which entertained no idea of excluding Japanese immigration, I shall explain in the following two chapters; in this chapter I shall dwell upon Japanese immigration before the exclusion understanding-its extent, its nature, its comparison with European immigration. A discussion of this nature, it may be said, is of historical interest rather than of practical value, as Japanese immigration has become a thing of the past. Yet an intelligent understanding of the Japanese immigration of anti-exclusion days is essential to an appreciation of the situation which necessitated an agitation of a most boisterous nature to compel the government at Washington to negotiate an exclusion agreement with Japan. When the real status of Japanese immigration is made clear, the American public will at least understand why the people, if not the government, of Japan cannot help feeling that the exclusion agreement is not in accord with the principle of fairness and justice.

Japanese immigration into America may be said to have begun in I886, when there were 194 immigrants from Japan. True, as early as I 866 Japanese began to enter this country in small numbers, but up to 1885 the 
figures remained almost stationary, as is shown in the following table:

\begin{tabular}{|c|c|}
\hline Year & $\begin{array}{c}\text { Number European } \\
\text { Immigrants }\end{array}$ \\
\hline I 866 & 278,916 \\
\hline 1867 & $283,75 \mathrm{I}$ \\
\hline 1868 & 130,090 \\
\hline 1869 & $3^{15}, 963$ \\
\hline 1870 & 328,626 \\
\hline $187 \mathrm{I}$ & 265,145 \\
\hline 1872 & $35^{2,155}$ \\
\hline 1873 & $397,54 \mathrm{I}$ \\
\hline 1874 & 262,783 \\
\hline 1875 & $182,96 \mathrm{I}$ \\
\hline 1876 & 120,920 \\
\hline 1877 & 106,195 \\
\hline 1878 & 101,612 \\
\hline 1879 & 134,259 \\
\hline 1880 & $348,69 \mathrm{I}$ \\
\hline I $88 \mathrm{I}$ & $5^{28,545}$ \\
\hline 1882 & 648,186 \\
\hline 1883 & $5^{22,587}$ \\
\hline 1884 & 453,686 \\
\hline 1885 & 353,083 \\
\hline
\end{tabular}

Number Japanese

Immigrants

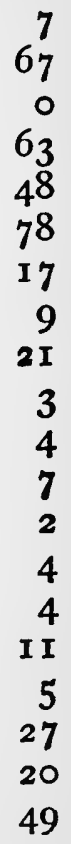

The enactment of the Chinese exciusion law in 1884 created a situation which facilitated the introduction of Japanese labor into California. The large landowners of that state, having been deprived of Chinese farm hands, found in the Japanese an excellent laborer to be utilized on their farms and orchards, and tried to encourage Japanese immigration by offering alluring terms. The result began to be perceptible two years after the enactment of the Chinese exclusion law, when there were 194 immigrants from Japan. Since that time the increase of Japanese immigration was so steady that in I89I it exceeded a thousand.

Towards the latter part of the nineties a new factor was 
injected into the situation, opening a wider field of employment for Japanese labor. The western railroads had found out that the Japanese made excellent section hands, and tried every means to obtain as many Japanese as possible. Thus in 1899 Japanese immigration rose to 2,844 . In the year following the figures suddenly leaped to 12,635 , but this extraordinary phenomenon was due to the fact that in that year Japanese immigration to Hawaii was for the first time included in the immigration statistics of the United States. In fact more than half the total Japanese immigrants came to Hawaii. Meanwhile, the railroads continued to employ Japanese laborers in increasing numbers, while the general prosperity which prevailed in this country up to 1907 stimulated Japanese immigration as much as it encouraged European immigration. The high water-mark in Japanese immigration was reached in 1907 when it numbered no less than 30,226. In the following table Japanese immigration from 1886 to 1907 is compared with European immigration for the same period:

\begin{tabular}{|c|c|c|}
\hline Year & $\begin{array}{c}\text { Number European } \\
\text { Immigrants }\end{array}$ & $\begin{array}{c}\text { Number Japanese } \\
\text { Immigrants }\end{array}$ \\
\hline $\begin{array}{l}1886 \\
\text { r } 887\end{array}$ & $\begin{array}{l}329,529 \\
3\end{array}$ & I 94 \\
\hline $\begin{array}{r}1887 \\
1888\end{array}$ & $53^{8,}$ I 3 I & $\begin{array}{l}229 \\
404\end{array}$ \\
\hline 1889 & 434,790 & 640 \\
\hline 1890 & 445,680 & 691 \\
\hline 1891 & 546,085 & r, 136 \\
\hline 1892 & 608,472 & I, 498 \\
\hline 1893 & $429, \mathrm{I} 39$ & 1,380 \\
\hline I894 & $279,05^{2}$ & I,93I \\
\hline 1895 & 250,342 & $\mathrm{I}, \mathrm{I} 5^{\circ}$ \\
\hline 1896 & 329,067 & I, I IO \\
\hline 189 & 216,397 & I, 526 \\
\hline & 217,786 & 2,230 \\
\hline
\end{tabular}




$\begin{array}{cc}\text { Year } & \begin{array}{c}\text { Number European } \\ \text { Immigrants }\end{array} \\ \text { 1899 } & 297,349 \\ 1900 & 424,700 \\ \text { 1901 } & 469,237 \\ 1902 & 619,068 \\ 1903 & 814,507 \\ 1904 & 767,933 \\ 1905 & 974,273 \\ 1906 & 1,018,365 \\ 1907 & 1,199,566\end{array}$

Number Japanese

Immigrants

2,844
12,635
5,269
14,270
19,968
14,264
10,331
13,835
30,226

We have traced Japanese immigration up to 1907 , the year in which the agitation of the trades unions in California culminated in the Japanese exclusion agreement. Reserving for later chapters the history of this agitation and the status of Japanese immigration after the said agreement, let us here examine more critically statistics pertaining to Japanese immigration for several years previous to the exclusion agreement, when Japanese came to these shores in larger numbers than in any other period.

We can comprehend the extent of Japanese immigration more clearly when we compare it with that from those European countries which furnish this country with most immigrants. This comparison is shown in the following table:

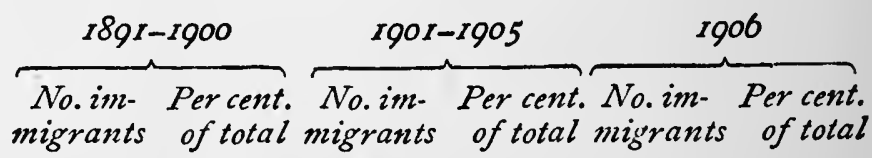

\begin{tabular}{|c|c|c|c|c|c|c|}
\hline Japan & $\begin{array}{r}24,806 \\
592,707\end{array}$ & 16.67 & $\begin{array}{r}64,102 \\
044,239\end{array}$ & $\begin{array}{l}1.7 \\
25 .\end{array}$ & $\begin{array}{r}13,835 \\
26,138\end{array}$ & $\begin{array}{l}\mathrm{r} .3 \\
24 .\end{array}$ \\
\hline Germany & $\begin{array}{l}592,707 \\
505,152\end{array}$ & 14. & $\begin{array}{l}944,239 \\
\mathbf{1} 76,995\end{array}$ & 4.6 & $\begin{array}{r}20,1,30 \\
37,564\end{array}$ & $\begin{array}{l}2 . \cdot \\
3.4\end{array}$ \\
\hline Italy & 651,893 & I8. & 959,768 & 25. & $273, \mathrm{I} 20$ & . \\
\hline Russi & 505,290 & 14. & 658,735 & 17. & 215,665 & 20. \\
\hline Ireland & 388,416 & Io. & $\begin{array}{r}184,095 \\
\end{array}$ & 4.8 & 34,995 & 3.2 \\
\hline veden & 5,266 & & & 4. & 23,310 & \\
\hline rway & , & 2.6 & & 2.7 & 2I, & \\
\hline & 15 & & 4 & I & & \\
\hline
\end{tabular}


We learn that in the decade from I89 I to 1900 Japanese immigration was so insignificant that it admits of no comparison with that from European countries. In the five years following, Japanese immigrants numbered, roughly speaking, only one in twenty-five compared with Austro-Hungarian and Italian immigrants, and one in seventeen compared with Russian immigrants. Again, in the year 1906 Japanese immigrants were only onetwenty-fourth as numerous as Austro-Hungarian immigrants, one-twenty-fifth as compared with Italian immigrants, one-eighteenth with Russian immigrants, and one-third with Irish and German immigrants.

The figures in the above table include Japanese immigrants both to Hawaii and the mainland of America. To ascertain, therefore, the true significance of Japanese immigration to the Pacific Coast, it is essential to inquire into the destinations of Japanese immigrants. The Japanese government endeavored, even before the exclusion agreement, to restrict as much as possible the number of passports to continental United States. Hence, more than one-half of Japanese immigrants were destined to Hawaii, where there was no ill-feeling towards the Japanese, the mainland of America having received a comparatively small number of Japanese. The apportionment of Japanese immigrants among Hawaii and the Pacific Coast states is shown in this table:

$\begin{array}{lrccc}\text { Year } & \text { Hawaii } & \text { California } & \text { Oregon } & \text { Washington } \\ 1902 & 9,125 & 2,518 & 130 & 2,419 \\ 1903 & 13,045 & 4,511 & 329 & 1,820 \\ 1904 & 6,590 & 4,003 & 318 & 2,446 \\ 1905 & 6,692 & 2,022 & 279 & 1,200 \\ 1906 & 9,051 & 2,068 & 398 & 1,619 \\ 1907 & 20,865 & 3,691 & 447 & 3,226\end{array}$


It will be seen that while Japanese immigrants in 1907 were so many as 30,226 , more than two-thirds of the total came to Hawaii. But the bearing of Japanese immigration upon the Pacific Coast will be understood more fully when the proportion of the Japanese and the European immigrants coming to that section is ascertained. Thus we observe that the tendency on the Pacific Coast was, comparatively speaking, towards increasing the European population and decreasing the Japanese. In 1903 the proportion of Japanese to European immigrants to the three Pacific Coast states was 3 to 11.3 ; in 1904,3 to 12.5 ; in 1905,3 to 20.3 ; in 1906, 3 to I9.1.

The destinations of immigrants given in the immigration statistics of the United States are merely those professed by individual immigrants upon their arrival in this country. Hence the actual destinations of Japanese are frequently different from those recorded by the immigration officials. As a matter of fact, Japanese immigrants are more widely scattered over different parts of the country than the report of the Commissioner-General of Immigration shows them to be.

The most powerful argument against Chinese immigration previous to the enactment of the Chinese exclusion law was that they flocked to the state of California, and so were likely to jeopardize the growth and occupancy of that state by Americans. The Chinese immigrants from I 854 to 1882 totalled I 39,455 , the overwhelming majority of whom came to and remained in California. In view of the fact that in the seventies of the past century, when agitation for Chinese exclusion was begun, the state of California had a population of only 560,000 , including negroes, Indians and Chinese, the apprehension 
that the Chinese might hinder the wholesome growth of the white community in that state was not without ground. But the conditions on the Pacific Coast have since radically changed, while circumstances attendant upon Japanese immigration are widely different from those accompanying Chinese immigration. Up to 1900 the white population of California (excluding negroes, Indians, Chinese and Japanese) increased to $\mathrm{I}, 402,727$. In 1870 the population of Oregon was only 90,923, and that of Washington only 23,955, both including negroes, Indians and Chinese; but the census of 1900 reports the population of Oregon at 394,582 , and that of Washington at 496,304 , both excluding negroes, Indians, Chinese and Japanese. It is needless to say that during the seven years that followed the year I900 the white population on the Pacific Coast increased even more rapidly than in the years preceding. And the increase of the white population is merely one of many factors which go to solidify the American community on the Pacific Coast. It may, therefore, well be asked whether the argument advanced against Chinese immigration in the eighties can reasonably be applied to the Japanese immigration of to-day.

We have studied Japanese immigration up to the conclusion of the exclusion agreement with special reference to its extent and its destinations. The next question which requires our attention is that of the nature of Japanese immigration-its classification by occupation, its financial conditions, its state of education.

A study of the reports of the Commissioner-General of Immigration reveals that the Japanese immigrants were not necessarily recruited from among the lowest classes of laborers. To call them "coolies" without dis- 
crimination is not to render them justice. The occupations of Japanese immigrants for the eight years from 1899 to 1906 are shown in the following table:

\begin{tabular}{|c|c|c|c|c|c|c|c|}
\hline Year & $\begin{array}{c}\text { Profes. } \\
\text { sional }\end{array}$ & Skilled & Farmers & $\begin{array}{c}\text { Farm } \\
\text { laborers }\end{array}$ & Laborers & Merchants & Servants \\
\hline 1899. & - 92 & I2I & 828 & 854 & 203 & $60 x$ & 53 \\
\hline 1900. & .563 & 1,793 & 2,521 & 3,855 & $x, 977$ & 797 & 223 \\
\hline 1901. & . 167 & 603 & 897 & 1,153 & 830 & 652 & 181 \\
\hline 1902 . & . 222 & I,047 & 5,212 & $45 I$ & $1,55^{8}$ & 1,205 & 173 \\
\hline 1903. & .274 & 922 & 5,010 & 5,816 & 572 & 1,442 & 132 \\
\hline 1904 & 373 & $64 \mathrm{I}$ & 121 & 6,775 & 1,474 & 1,184 & 317 \\
\hline 1905 & . 280 & $35^{8}$ & $3^{80}$ & 5,883 & 743 & 777 & 207 \\
\hline 1906 & .256 & 329 & 522 & 8,435 & 835 & $63^{2}$ & 195 \\
\hline
\end{tabular}

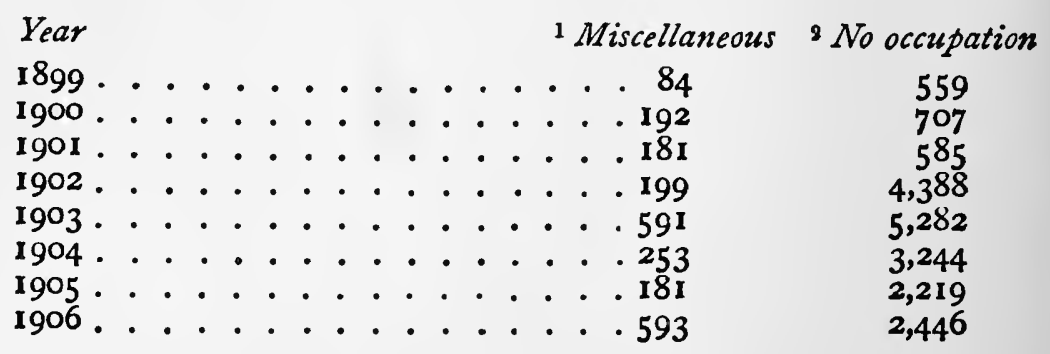

The meaning of the above table will be understood more fully when the figures for each occupation are reduced into percentage of the total Japanese immigrants and compared with figures representing each occupation of European immigrants, likewise rendered into percentage. For this purpose the following table is prepared, comparing the Japanese immigrants for 1906 with those from several European countries:

1 This consists of agents, bankers, hotel keepers, manufacturers and fishermen.

2 This includes women and children under fourteen years. 
People or race

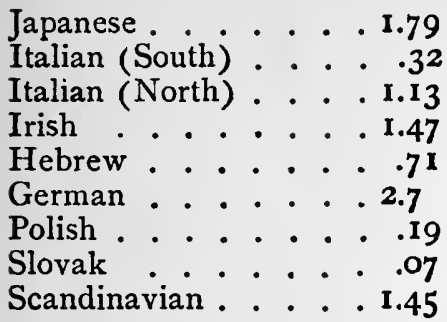

Skilled Farmers

2.16
12.63
11.15
11.56
33.26
18.86
6.19
3.79
19.11

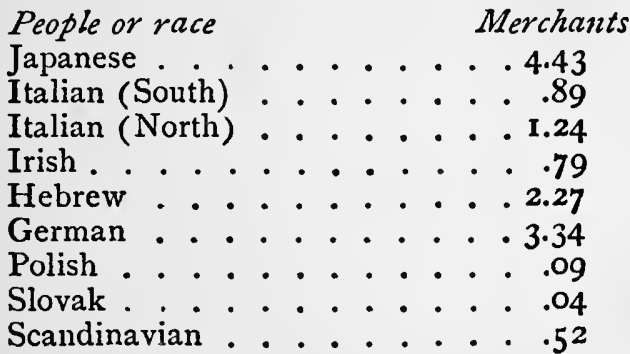

Farm Laborers laborers

59.22 $30.5^{8}$

11.08

$5 \cdot 36$

I.I I

1 4.17

33.64

46.17

6.45

5.86
29.41
37.94
24.8
5.44
7.58
23.35
12.31
25.82

Servants

I. 36

4.50

6.82

36.6

6.39

1 $3.5^{8}$

I6.3

14.4

24.02

From this table it will be seen that the majority of Japanese immigrants were farmers and farm laborers. Common laborers, who are apt to crowd in the city, formed a very small portion of Japanese immigrants, viz., only five per cent. as against twenty-nine per cent. from South Italy, thirty-seven per cent. from North Italy, twenty-four per cent. from Ireland, twenty-three per cent. from Poland and twenty-five per cent. from Scandinavia. With the exception of Germany, Japan furnished the largest percentage of professional men. In examining these figures it is necessary to remember that they include those for Hawaii, which received the majority of Japanese laborers given in the table.

It is worthy of note that the per capita sum of money shown by Japanese immigrants at the time of landing is smaller only than that possessed by English and German immigrants. In the fiscal year 1905, the average sum of money brought by English and German immigrants was 
$\$ 57.65$ and $\$ 43.72$ per capita, respectively, while Japanese immigrants brought $\$ 37.78$ each. In 1906 English immigrants brought $\$ 57.90$ per capita, Germans $\$ 40,87$, and Japanese $\$ 31.09$. In the following table the per capita sum of money shown by Japanese immigrants in 1905 and 1906 is compared with that brought by immigrants from various European countries other than England and Germany.

\begin{tabular}{|c|c|c|c|c|c|}
\hline Race or people & & & $\begin{array}{c}\text { Number } \\
\text { immigrants }\end{array}$ & $\begin{array}{l}\text { Total amount } \\
\text { money shown }\end{array}$ & Per capita \\
\hline Japanese & & & . 11,021 & 416,395 & 37.78 \\
\hline Italian (South) & & & . 186,390 & $3,127,207$ & 16.77 \\
\hline Italian (North) & & & - $39,93^{\circ}$ & $1,169,980$ & 26.79 \\
\hline Irish . . . . & & & . 54,266 & $1,421,682$ & 26.19 \\
\hline Hebrew & & & . 129,910 & $1,824,617$ & 14.04 \\
\hline Polish & & & $.102,437$ & $1,35^{2,230}$ & 13.20 \\
\hline Scandinavian & & & - 62,284 & $1,604,205$ & $25 \cdot 75$ \\
\hline Slovak . & & & 52,368 & 818,207 & 15.43 \\
\hline Magyar & & & . 46,030 & 695,108 & 15.10 \\
\hline Croatian-Slovenia & & & - 35,104 & 539,337 & $15 \cdot 36$ \\
\hline Russian ... & & & 3,746 & 133,576 & 35.65 \\
\hline
\end{tabular}

\begin{tabular}{|c|c|c|c|c|}
\hline Race or people & & $\begin{array}{c}\text { Number } \\
\text { immigrants }\end{array}$ & $\begin{array}{l}\text { Total amount } \\
\text { money shown }\end{array}$ & Per capita \\
\hline Japanese & & . 14,243 & 442,909 & $3^{1.09}$ \\
\hline Italian (South) & & . 240,528 & $3,637,787$ & 10.96 \\
\hline Italian (North) & & . 46,286 & $1,237,404$ & 26.73 \\
\hline Irish & & . 40,959 & $1,082,33^{2}$ & 26.42 \\
\hline Hebrew . & & . 153,748 & $2,362,125$ & $15 \cdot 3^{6}$ \\
\hline Polish & & . 95,835 & $1,103,955$ & II. 5 I \\
\hline Scandinavian & & . $58,14 \mathbf{I}$ & $1,542,129$ & 26.52 \\
\hline Slovak & & . 38,221 & 526,028 & 13.76 \\
\hline Magyar & & . $44,26 \mathrm{I}$ & 621,077 & 14.03 \\
\hline Croatian-Slovenia & & 44,272 & $5^{82,503}$ & 13.15 \\
\hline Russian . . & & 5,814 & $159,25 \mathrm{I}$ & 25.67 \\
\hline
\end{tabular}

The above figures account for the fact that only an infinitesimal portion of Japanese immigrants were afforded aid in hospitals in this country, while European countries furnished hundreds, even thousands of immigrants re- 
lieved in hospitals. It is also natural that only a very small number of Japanese immigrants were denied admission on the ground of being paupers or likely to become public charges. In the following table the number of Japanese afforded aid in hospitals in 1906 is compared with that of European immigrants so relieved :

\begin{tabular}{|c|c|c|c|}
\hline Race or people & $\begin{array}{l}\text { Number } \\
\text { immigrants }\end{array}$ & $\begin{array}{l}\text { Relieved } \\
\text { in hospital }\end{array}$ & Per cent. \\
\hline Japanese & . 14,243 & I & .007 \\
\hline Italian (South) & . 240,528 & 1,776 & .73 \\
\hline Italian (North) & . 46,286 & 346 & .74 \\
\hline Irish & - 40,959 & 214 & $.5^{2}$ \\
\hline Hebrew & $.153,748$ & 2,495 & 1.62 \\
\hline Greek & . 23,127 & 189 & $.8 \mathrm{r}$ \\
\hline German & . 86,813 & 867 & .99 \\
\hline Polish & . 96,835 & 1,000 & 1.04 \\
\hline Scandinavian & - 58,141 & 179 & .3 \\
\hline
\end{tabular}

We see that out of the entire Japanese immigrants only one was relieved in hospital. This is almost naught by the side of the enormous number of European immigrants who became public charges in the same year. The fact that so few Japanese became public charges is due not only to their happy financial condition, but also to the presence among them of a very small number of the aged and infant. Almost ninety-eight per cent. of Japanese immigrants for 1906 were in the ages from fourteen to forty-four, leaving only two per cent. for the aged and infant; whereas ten to thirty-three per cent. of immigrants from various European countries were under fourteen or over forty-four years.

Now we are in a position to consider the educational condition of Japanese immigrants. Owing to the fact that the Japanese language is radically different from English, it requires considerable time and labor for a Japanese to acquire a knowledge of English. A com- 
pulsory educational system is adopted in Japan as far as primary education is concerned, but in the primary school no foreign language is taught. It is only in the high school that the English language finds place in the studies. Naturally many a Japanese, when arriving in this country, has no knowledge of English. And yet the rate of illiteracy among the Japanese immigrants, though larger than those among English, Irish, German and Scandinavian immigrants, is considerably smaller than the rates of illiteracy among South Italians, Ruthenians, Lithuanians, Poles, Croatians and Slovenians, etc. The Commissioner-General of Immigration's report for I904 contains a very instructive chart, showing the rates of illiteracy among immigrants from different countries. From this chart the following table is prepared, comparing the percentage of illiteracy among the Japanese immigrants with that among the immigrants from those European countries which furnish this country with more than twenty per cent. of illiterates:

Race or People

Per cent. of illiterates

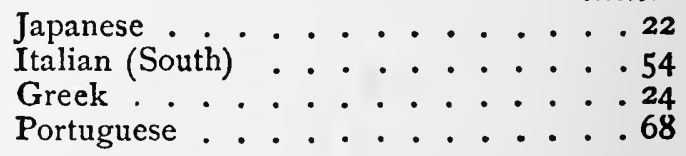

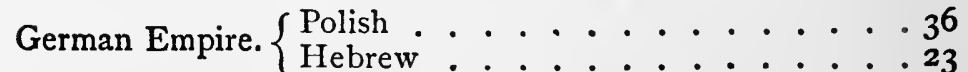

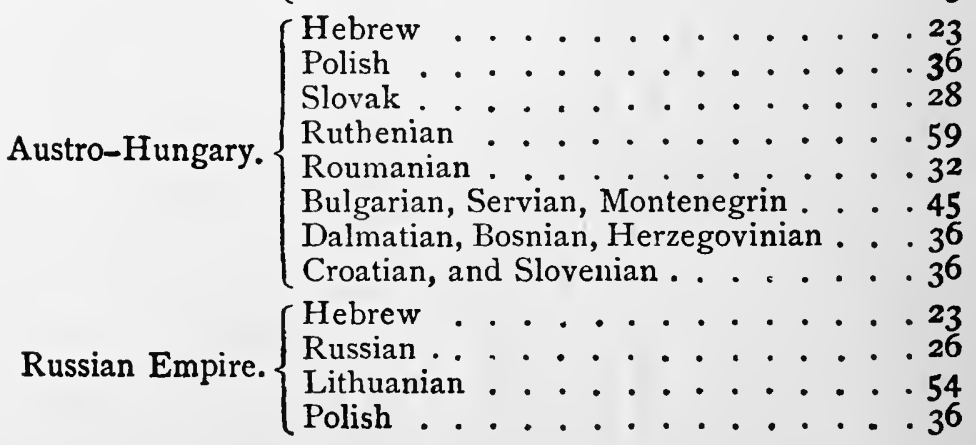


According to this table twenty-two out of every hundred Japanese were illiterate, forming the smallest rate of illiteracy in the list. The largest rate of illiteracy was among the Portuguese, viz., sixty-nine per cent., the Ruthenians came next, the South Italians and Lithuanians third, the Bulgarians, Servians and Montenegrins fourth, the Poles fifth, and so on.

No discussion of Japanese immigration would be complete which does not consider its bearing upon the economic conditions of the Pacific Coast. Such a consideration seems especially necessary as the Japanese immigrant has been accused of lowering the wages of American laborers. My inquiry into the matter leads me to the conclusion that this charge is not founded upon any fact that can be substantiated. This question, so far as California is concerned, will be minutely discussed in a separate chapter; here I am concerned with conditions that prevailed in Washington and Oregon at the time when the exclusion agreement was entered into.

The Japanese immigrants were engaged in the kinds of work in which American laborers did not care to be employed. They did not, as a rule, compete with American laborers. True, in certain kinds of works the Japanese were paid less than were American laborers, but this does not mean that they sold their labor at a cheap price. On the contrary, they were getting the highest wages they could reasonably ask. Where they accepted smaller wages than were paid white working men, they did so merely because their physical strength was not equal to that of their white fellow working men, or because they were unable to speak English or unfamiliar with the tools they had to use. And yet in any kind of work the Japanese were not getting much smaller wages 
than were the American laborers. Let us illustrate this with the case of the Japanese in Washington.

In 1906 there were in Washington some 12,894 Japanese, of whom 697 and 288 were independent business men and farmers, respectively. Of the remaining Japanese population the following classification was obtained :

Sawmill laborers and wood-cutters . . . . . . 2,685

Railroad laborers .. . . . . . . . . . . 2,332

Farm laborers . . . . . . . . . . . . . I,234

Fishery and cannery laborers . . . . . . . . 904

Housework . . . . . . . . . . . . 1,204

Hotel, store and restaurant laborers . . . . . . 3, or 4

Miscellaneous laborers .. . . . . . . $53^{6}$

The wages of these Japanese laborers were approximately as follows :

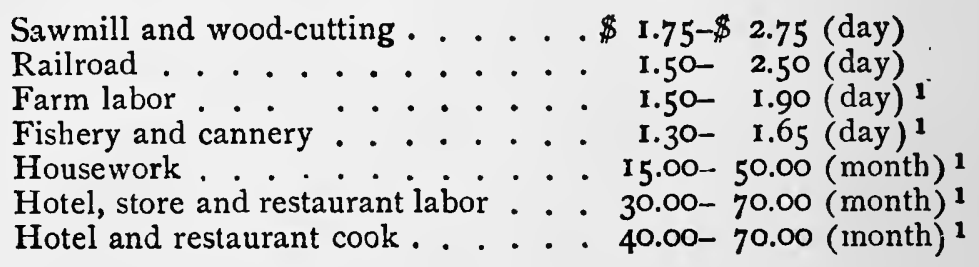

That these wages were not, with a few exceptions, smaller than the wages of American laborers will be understood when the above table is compared with the following table based upon the report of the Bureau of Labor of Washington, showing the average wages of various kinds of labor in which most Japanese laborers were engaged:

1 With room and board. 
Occupation

Average wages

Section foreman (Great Northern Railroad) . . .\$1.80-\$2.00 (day)

Section hand (Great Northern Railroad) . . . . I.35- I.50 (day)

Section foreman (Northern Pacific Railroad) . . 2.07 (day)

Section hand (Northern Pacific Railroad) . . . $\quad$ I.47

Section foreman (Oregon Railroad) . . . . . I.9 I

Section hand (Oregon Railroad)

Section foreman (Columbia and Puget Sound

Railway) (Columbia and Puget Sound Rail-

way) . . . . . . . . . .

Section foreman (Washington and Columbia Railroad) . . . . . . . . . .

Section hand (Washington and Columbia Railroad)

I.75

(day)

2.16- 2.33 (day)

I.30- 1.75 (day)

I.93

(day)

1.50

Common labor at mercantile establishment (Seattle) .

Common labor at mercantile establishment ( $\mathrm{Ta}$ coma) ............ .

Common labor at mercantile establishment (Spokane) . . . . . . . 3440 (day)

Restaurant cooks . . . . . . . 45.00- 90.00 (month)

Restaurant waiters . . . . . . 30.00- 60.00 (month)

The conditions, prevailing in Washington in 1906, also prevailed, with but little modification, in Oregon and other states in the Pacific Northwest.

When the state of California began to agitate for the exclusion of the Chinese, even the merchants and dealers in that state countenanced the movement; for the reason that the Chinese immigrant did not consume American goods, importing almost all of his living requirements from his native country. On the other hand, merchants and dealers of the Pacific Coast do not, generally speaking, favor the agitation against the Japanese, whose daily requirements, with the exception of a few things, are bought in this country. Indeed, it may be safe to say that the mercantile class on the Pacific Coast is willing to welcome Japanese immigrants.

On this point, the following passage from the "Second Biennial Report of the Bureau of Labor 
Statistics of the State of Oregon" may be read with interest:

"It is shown that of the food and materials consumed by the Chinaman, sixty per cent. is foreign and forty per cent. domestic. On the other hand, the Japanese imports only eleven per cent. of his living requirements from his native land, the balance, or eighty-nine per cent., being domestic. The Japanese purchases all of his clothing in the United States, amounting to fifteen per cent. of his articles of subsistence, while of his food, which represents eighty-five per cent. of his living expenses, eighty-seven per cent. is domestic and thirteen per cent. foreign. Eighty-one per cent. of the Chinaman's subsistence is food, of which proportion seventy-five per cent. is foreign and twenty-five per cent. domestic, and the balance, or nineteen per cent., is clothing, all domestic."

Such, in brief, was the status of Japanese immigration immediately before the conclusion of the exclusion agreement of 1907. Considering the facts and figures we have set forth, it may well be questioned whether such a drastic measure of exclusion as was adopted by the mutual consent of the United States and Japan was justified. That the administration at Washington did not wish to put a ban upon Japanese immigration may be inferred from the fact that Mr. Roosevelt in his message to Congress in 1906 eulogized the Japanese in the most glowing terms, and went so far as to urge that the Japanese should be naturalized. About that time, however, an untoward situation was developing in California, furnishing the anti-Japanese agitators with a golden opportunity to push their movement. But for that peculiar situation the anti-Japanese propaganda in California might never have assumed the formidable proportions that it did. 
This situation was created by the immigration en masse of Japanese in Hawaii to the mainland of America. The higher wages paid on the Pacific Coast were an irresistible temptation to the Hawaiian Japanese. Indeed, many a Japanese, unable to obtain passports to continental America, came to Hawaii only to make that point a stepping stone to the Pacific Coast. The Japanese government, while exercising its utmost influence to restrict the emigration of its subjects to continental United States, did not feel constrained to limit passports to Hawaii, knowing that Japanese labor was needed and welcomed there. But the good intentions of the Japanese government were misused by many a Japanese, who secured a passport to Hawaii with no intention to remain there. Nor was this surprising, considering that the wages paid the sugar plantation laborer in Hawaii were scarcely as much as half the wages paid the farm laborer on the Pacific Coast. So the Japanese exodus from Hawaii grew to such dimensions as alarmed the sugar planters, while in California it created suspicion among the trades unions. The great sugar interests in Hawaii tried every means to check the migration of Japanese from the island, without, of course, increasing their wages. Indeed, it was even alleged that they entered into alliance with the trades unions and some of the newspapers in California. At any rate their united propaganda proved so successful that the government at Washington was obliged to meet their demands. The result was the exclusion understanding of 1907, which not only stopped the migration into the mainland of Japanese laborers in Hawaii but denied admission to those who came direct from Japan. 


\section{XIX}

\section{DENIS KEARNYISM ONCE MORE-I}

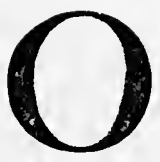

NCE upon a time there was a man who told an elephant that he would take the animal into paradise, if he would only let him ride on his back to make the trip. The elephant nodded a consent, and the man and the animal started in quest of the beautiful world, the man guiding the reins with his cunning intellect, the elephant trotting forward with ponderous feet. The goal was at last reached, but when the doors of paradise were ajar, the man slipped in, leaving the elephant behind to his grief and disappointment.

How often is the old story exemplified in our midst in these blessed days of the twentieth century! Demagogues, like the cunning man of old, now and again hold out alluring promises before the public, declaring that the promises will all be fulfilled if the public will follow their lead, or what is better, put itself under their reins, as did the elephant in the fable. The public is readily coaxed to gratify the desire of the agitators ; so they become good friends for the nonce, and start on a journey to the promised land. Would that the good-natured people might awaken to the knowledge that they are dupes of the agitators! But the knowledge seldom dawns upon them until the journey is ended, only to make themselves sorry figures.

Thus it was that the anti-Japanese agitation on the Pacific Coast of a few years ago began and subsided. It 
was the old story-some one wanted to go to the Senate or the House, or some one had the gubernatorial bee buzzing in his bonnet, or some one wanted to sell his paper, or some one wanted to make a living by levying upon the innocent laborers, or some " interests " wanted to control Japanese labor for their exclusive benefit. Seeing that Japanese immigration was beginning to be a cause of apprehension to the laboring class of California, these men joined hands, setting their minds to make the most of it. A drunkard broke into a Japanese restaurant, or a rowdy tried to extort money from a Japanese shopkeeper, and such trifling incidents were readily converted by evil-schemers into an occasion to arouse animosity and hatred against the Japanese in general. Their demonstration was so loud and noisy that the voice of sane counsel was drowned and silenced, and the public, like the poor elephant in the old story, was once again straddled by crafty riders.

It was the twenty-third day of December, 1906. A mass-meeting was held in Walton Hall, San Francisco, to demonstrate the animosity of the laboring class against the Japanese. It was presided over by one O. A. Tveitmoe. That man, I was told, was the instigator of the anti-Japanese agitation, the Denis Kearny of the time. He rose to speak, and in the climax of his peroration he shouted: "If Americans and Japanese married the result would be a nation of gas-pipe thugs and human hyenas!" Ah, that was a monumental speech! Then appeared upon the platform P. H. McCarthy, the man who was later elected mayor of San Francisco. His harangue frothed with bellicose utterances, and his audience, unkempt and sullen, approved him with tremendous applause, when he screamed at the height of his 
voice: "California and the states west of the Rockies alone could whip Japan into a jelly."

About a year later I chanced to attend another massmeeting, this time in Portland, Oregon. Senator Gearin was the star speaker of the evening. In florid terms our distinguished senator told his audience how beautiful and cultured and moral the city of Portland was, and declared that a city like that should not be polluted by hordes of barbaric Japanese. And there were but a few Japanese in Portland at the time! The Honorable Gearin was followed by one Reverend Mr. Wilson. This disciple of Christ's was pious enough to invoke God's name in emphasizing his condemnation of the Japanese, and declared, with voice trembling, that the Japanese must be excluded because "they are a race that live on rice and rats"! Then came another orator-but why waste words on the fatuous vociferations of these apostles of exclusion? What has been said is enough to indicate the nature of the agitation and agitators. It is more vital to review the history of the anti-Japanese movement.

O. A. Tveitmoe, the organizer of the Japanese and Korean Exclusion League, was born in Norway in 1865 . In the latter eighties he emigrated to the United States and located in Minnesota, a state which had long been the Mecca of Norwegian immigrants. A crafty man, he did not think it worth his while to till the soil, as did his fellow immigrants, and preferred the dignified calling of a political agitator. In 1892 he was engaged in agitations favorable to the Farmers' Alliance in a small town in Minnesota. About this time he committed a blunder, which stamped an ineffaceable taint upon his life. In spite of the noble calling to which he dedicated himself, his eyes were not insensible to the tempting glitter of 
gold, and while writing as a reporter on a small Norwegian weekly paper, he forged the name of a local merchant to a note for $\$ 200$ and negotiated it. He was convicted and sentenced to eighteen months in the state prison at Stillwater, Minn., where, after serving a part of his sentence, he was pardoned by the governor. Then he moved to San Francisco, where he gradually distinguished himself in the camp of labor unions, until he was appointed secretary of the Building Trades Council of that city. What mischievous souls they must have been who, on the morrow of Tveitmoe's glorious ascent to the long-coveted post, mercilessly dragged to the garish light of day the unhappy past of the ambitious Norwegian! The San Francisco Bulletin, in attacking the corrupt administration of Mayor Schmitz, incidentally published, in November, 1907, the infamous story of the note-forgery episode, which made Tveitmoe an inmate of a Minnesota penitentiary. The story was even illustrated with the official prison photographs of the erstwhile criminal. The Bulletin's attack upon Tveitmoe was made upon the assumption that his appointment by Mayor Schmitz to be a member of the board of supervisors was a reflection upon the integrity of the mayor himself and his administration. Yet Tveitmoe was not daunted, nor was the laboring class, which exalted him to the post he then occupied, ashamed of him. And why should they? Tveitmoe had washed his hands of the stain of the forgery incident, and was now, to all appearances, a gentleman.

Such, in brief, is the personality of the hero of the antiJapanese agitation which was begun on the Pacific slope in 1905. It was on May 7 th of that year that an antiJapanese convention was for the first time held in San Francisco. For months previous, the San Francisco 
Chronicle and Mr. Tveitmoe's paper, the Organized Labor, had been engaged in stirring up ill-feeling against the Japanese in California. For a month or so beginning with February 23, 1905, the Chronicle published day after day the most sensational articles inveighing against the Japanese; even after that, articles of much the same nature continued to appear at frequent intervals in the columns of that paper. The Organized Labor was even more sensational and vehement in arraigning the Japanese. And yet their agitation apparently failed to kindle enthusiasm among the San Franciscans, for the convention of May 7 th proved to be a tame affair, attended by a comparatively small number of delegates, most of them politicians. The delegates were but half-hearted in advocating the exclusion of Japanese; they came to the convention apparently for political effect. However, a resolution was adopted, protesting against " the national policy, laws, and treaties which allow Japanese to enter our ports, to the great detriment of our citizenship, our standard of living, and the progress of American civilization."

In spite of the apparent indifference of the Californians towards the campaign of the Chronicle and Mr. Tveitmoe, it cannot be said that the movement was ill-timed. The municipal government of San Francisco had been in the hands of trade-union bosses, with the now ill-famed Schmitz at its head. Hatred of Japanese immigrants seemed to have pervaded the city hall, and on May 6, 1905,- - the day before Tveitmoe called together the first anti-Japanese convention-the Board of Education of the city had passed a resolution declaring it to be necessary to segregate Japanese from white pupils. It seemed as if Tveitmoe's agitation had been officially endorsed, even invited, by the municipal authorities. So our Norwegian 
labor leader did not feel disconcerted by the lack of enthusiasm at the first anti-Japanese convention, and proceeded to organize what was to be known as the Japanese and Korean Exclusion League.

About five months after its organization, or to be more accurate, on October 22, 1905, the Japanese and Korean Exclusion League convened a mass-meeting, which adopted a resolution instructing its executive committee to appear before the Board of Education, and petition for the establishment of separate schools for Japanese children. It will be noted that the resolution of the education board of May 6, 1905, which we have just mentioned, had never been carried into effect. The petition of the Exclusion League was duly laid before the board, and yet nothing was done about the matter. Then came the earthquake of April 18, 1906, which reduced to débris thirty-six of the seventy-six schools in San Francisco. This furnished a golden opportunity for the anti-Japanese municipal government to carry out the segregation of Japanese pupils, which for want of plausible excuse had been deterred. Pleading that the schools surviving the calamity were inadequate even to accommodate white children, the education board, on October I I, 1906, ordered all Japanese pupils, together with Chinese children, to a separate school. At that time there were only ninety-three Japanese pupils distributed among twenty-three schools. With the exception of two, the number of Japanese in attendance at any one school did not exceed six. The greatest number of Japanese was at the Redding Primary School, where there were twenty-three. At this school there was room for many more pupils than were attending. That, however, made no difference. Insufficient accom- 
modation was an excuse too transparent to deceive anybody; the real reason was malice and prejudice.

It cannot be gainsaid that the ordering of all Japanese pupils to one school was tantamount to the summary prohibition of their attending schools. The condition in San Francisco, incident to the earthquake and conflagration, was such that it was practically impossible even for adults living at remote distances to attend a school located in the burned section. Small wonder that there was only one Japanese student who attended the "Oriental School." The Japanese community in San Franciso, reasonably indignant at the discrimination, resolved to ignore the Oriental School and assume the education of Japanese children in its own hands.

Meanwhile, President Roosevelt was watching with the most serious concern the development of the antiJapanese propaganda in California. In his message to Congress dated December 6, 1905, he devoted several thousand words to the repudiation of the exclusion movement. The memorable document raised on all sides a storm of mingled wonder, wrath, and admiration. To follow it up, Mr. Roosevelt sent Mr. Metcalf to California to investigate the situation, and upon receiving Mr. Metcalf's report, addressed, on December I 8, a special message to Congress. His discussion of the Japanese question contained in his first general message may have seemed too effusive, too rhetorical, and indeed too vociferous to be convincing, but there can be no doubt that this second message touched the vital point without any of the faults of the message that preceded it. On the question of the segregation of Japanese children, the President said :

"I call your especial attention to the small number 
of Japanese children who attend school, to the testimony as to the brightness, cleanliness and good behavior of these Japanese children in the schools, and to the fact that, owing to their being scattered through the city, the requirement for them all to go to one special school is impossible of fulfillment and means that they cannot have school facilities.

"Let me point out further that there would be no objection whatever to excluding from the schools any Japanese on the score of age. It is obviously not desirable that young men should go to school with children. The only point is the exclusion of the children themselves. The number of Japanese children attending the public schools in San Francisco was small. The government has already directed that suit be brought to test the constitutionality of the act in question, but my earnest hope is that such suit will not be necessary, and that as a matter of comity the citizens of San Francisco will refuse to deprive these young Japanese children of education and will permit them to go to the schools."

As the President pointed out, the Japanese never objected to the exclusion of young men; but they could not bear to see all Japanese pupils, irrespective of age, driven out of the public school, simply because they were Japanese. Of the ninety-three Japanese pupils attending public schools when segregation was ordered, none was over twenty years of age, and only two were as old. Six were aged nineteen; six were eighteen years old; twelve seventeen; nine sixteen; and ten fifteen. The remaining forty-eight were between six and fourteen years old. As for the charge that Japanese pupils were morally inferior, and exercised baneful influence among white children, it was a calumny pure and simple, and 
could only reflect upon the character of those who uttered it. When the exclusion agitation was at its height Colonel Irish, naval officer at San Francisco, at a banquet of the Unitarian Club, read the following letter, written to him by an experienced public-school principal of San Francisco :

"I have had ample opportunities, in over twenty years of experience with Japanese students, to know whereof I speak, in all its bearings.

" No considerable part of these students are adults. Had the adult pupils ever reached as large a proportion as twenty per cent., there would, years ago, have been protests from teachers and principals, and Japanese adults could and would have been excluded from elementary day-school, just as other adults, without friction or objection.

" Japanese children do not crowd white children out of the schools. The San Francisco schools are not overcrowded. They never have been overcrowded during the past twenty years, except in a few spots, and that for causes entirely outside this matter.

" The statement that the influence of the Japanese, in our schools, have had a tendency towards immorality is false and absolutely without foundation. From all I have heard in conference with other school men, as well as from my own continuous and careful observation, there has never been the slightest cause for a shadow of suspicion affecting the conduct of one of these Japanese pupils. On the contrary, I have found that they have furnished examples of industry, patience, unobtrusiveness, obedience and honesty in their work, which have greatly helped many efficient teachers to create the proper moral atmosphere for their class rooms. 
"Japanese and American children have always been on good terms in my class rooms, and in others concerning which $I$ am informed. They work side by side, without interference or friction, and often some Japanese student would be a great favorite among his American classmates.

"In all my years of experience, there has never come, orally or in writing, from the parents whose children have attended my school, one hint of complaint or dissatisfaction concerning the instruction of their children in the same school or the same rooms with Japanese. Nor has there ever been any complaint or protest from teachers in regard to this coeducation."

Views of the San Francisco school-teachers, almost without exception, bear testimony to the accuracy of this statement. I, of course, hazard no guaranty that no Japanese pupil has ever committed or will ever commit blunders. There may have been solitary cases of undesirable conduct on the part of Japanese pupils, but there can be no doubt that on the whole they are more docile, intelligent, industrious, orderly, and clean in habit than the average children of most immigrants from other countries. Let those, who scandalize Japanese pupils with invented tales of immorality, read the recent report of the Chicago Law and Order League, wherein it is stated that in the twenty-three months covered by the investigation, 600 Chicago school children occupied the wards in the county hospital devoted to disease resulting from immorality.

It is no pleasant task to narrate the school incident: let us bring our review of the question to a speedy conclusion. To state it briefly, then, the trouble ended in a compromise, as the result of the President's conference 
with Mayor Schmitz, which took place in Washington in February, 1906. That compromise was in the following form :

"First. Children of alien races who speak the English language, in order to determine the proper grade in which they may be enrolled, must first be examined as to their educational qualifications.

"Second. That no child of alien birth over the ages of ten, eleven, twelve, thirteen, fourteen, or sixteen years shall be enrolled in any of the first, second, third, fourth, fifth, sixth, seventh or eighth grades, respectively.

"Third. If said alien children shall be found deficient in their ability to speak, or deficient in the elements of the English language, or unable to attend the grades mentioned in Section 2 by reason of the restrictions mentioned therein, such children shall be enrolled in special schools or in special classes established exclusively for such children and in the manner the Board of Education shall deem proper and most expedient."

There is nothing extraordinarily favorable for Japanese children in this compromise, and it ought to have been attained simply on the ground of fairness and justice, without demanding of Japan any sacrifice therefor. As a matter of fact, it was made possible only by imposing upon Japan the condition that she should prohibit the emigration of her subjects to the United States. In other words Japan was forced to accept the alternative of exclusion in order to restore in the San Francisco public schools a handful of Japanese pupils. In the effort to avoid a Scylla the Japanese foundered upon a Charybdis, and the Exclusion League congratulated itself upon the success of its scheme to force the Japanese into the snare.

Just as the school question was a means to the end of 
excluding Japanese immigrants, so the violence and outrages, resorted to by the riffraff of the San Francisco population against the Japanese residents there, were calculated to facilitate the attainment of the same end, as the frequent occurrence of such violence and outrages would inevitably create with the American people an impression that there was an unbridgeable chasm dividing the Japanese from other races residing in this country. Let us see what such outrages were.

In backward countries where the administration of law is hopelessly lax, bands of robbers are subsidized by peaceable people to secure immunity from sudden attack. However incredible it may seem in a country of liberty and enlightenment, this is virtually what some Japanese business men in San Francisco had to do with trade-union men who tried to crush their business by violence. This phase of the question is clearly set forth in Secretary Metcalf's report to the President. For two or three weeks in October, 1905, several Japanese restaurants in San Francisco were subjected to frequent attacks by men professing to belong to labor unions. Windows and furniture were broken, stones were thrown, blows were struck, and customers attempting to enter any of the Japanese restaurants were restrained by force. Some days the rioters visited the Japanese establishments morning, noon, and evening, and their visits were accompanied by threats and intimidation if not by violence. So obnoxious and even dangerous had their activities become that the Japanese restaurant-keepers decided, towards the end of October, to pay money to the rioters to buy safety. A sum of $\$ 350$ was immediately raised, and an agreement was entered into with one W. S. Stevenson, the ringleader of the rioters, for the payment of that sum 
upon the condition that outrages be stopped. Of the $\$ 350$ the first payment was made to the amount of $\$ 100$, and as if by enchantment, the hoodlums ceased to loiter about the Japanese restaurants. Tennyson once sang that "The jingling of the guinea helps the hurt that honor feels," but in this case, the jingling of the dollar seemed to intensify the hurt that honor felt, for neither Stevenson nor his representative ever appeared to receive the remainder of the money promised by the Japanese.

Aside from the assaults upon the Japanese restaurants a score of Japanese were stoned and beaten by hoodlums and laborers. Among the Japanese thus attacked were Dr. F. Omori, of the Imperial University of Tokio, who, as stated by Prof. George Davidson, of the State University of California, is one of the greatest living authorities on seismography. Dr. Omori had been sent to San Francisco by the Imperial University to study the causes and effects of the earthquake. While engaged in observation in the field, he and his assistants were stoned by hoodlums. Dr. Nakamura, professor of architecture in the Imperial University of Tokio, who had also been sent there by the Japanese government to study the effects of the earthquake upon the buildings in San Francisco, was likewise subjected to a similar humiliating treatment. Yet these gentlemen, knowing that the outrages were committed by the merest riffraff of San Francisco, requested that no official recognition be taken of them. The Japanese at home fully appreciated that the majority of the San Franciscans did not approve of indiscreet agitation against their compatriots in California, and continued to entertain for the city stricken with earthquake and fire the most heartfelt sympathy, which manifested itself in the contribution towards the relief 
fund of $\$ 246,000$, a sum larger than that contributed by any other single country.

For the preservation of Japan's good-will through the dark days of the anti-Japanese campaign in San Francisco, much credit must be given to the actions taken by various other cities on the Pacific Coast, vindicating their sincere desire to be friends with the Japanese, in spite of San Francisco. While the abuse of the Japanese in San Francisco was going on, the cities of Los Angeles, Portland, Tacoma, and Seattle, through their respective chambers of commerce, declared at various times in February and March, 1907, that they were against any measure aimed at the segregation of Japanese pupils or the exclusion of Japanese immigrants. As the declarations were all framed virtually in the same spirit, if not in the same language, they may well be represented by the declaration issued by the Chamber of Commerce of Seattle. It was as follows :

"It is the opinion of the Seattle Chamber of Commerce that a majority of the people of the Pacific Coast are not in favor of any immigration law that will treat the people of Japan differently from the way in which we treat the people of any European country. We recognize that the United States and the empire of Japan are bound together by the ties of trade, commerce and old friendship, which in the past have proved of great advantage to both countries, and if preserved, contain a sure pledge of still greater benefits for the future. We believe that any immigration treaty, which would discriminate against Japan by denying to the people of that country ordinary rights or privileges granted to the people of other civilized nations, would be uncalled for and would be detrimental to the trade and commerce of the Pacific 
Coast, and, by checking the growth, development and prosperity of this section, would tend directly to narrow the field of employment for our own people and decrease the demand for our own labor. It would injure the Pacific Coast farmers by barring the way to a large and profitable market for flour and other foodstuffs. It would strike directly at those manufacturing industries throughout the country which are now supplying steel rails, machinery, food and appliances for the development of Japan, Korea and Manchuria. It would practically close Japan, Korea and Manchuria to American capital and to the use of American skilled labor that would otherwise be largely employed in the development of the resources of those countries.

"Moreover, as the enforcement of the terms of any new immigration treaty putting Japan on a different footing from that of other nations or any law or regulation made pursuant to such a treaty would necessarily be in the hands of bureau officials, its administration would, in our opinion, be almost certain to sow the seeds of disagreements, dissension and strife between the two countries.

"Therefore, be it resolved that in the opinion of this chamber it would be against the best interests of the Pacific Coast and of the whole country to conclude any treaty or enact any law, the effect of which would be to treat the people of Japan in a manner different from the treatment accorded to the people of other civilized powers."

This resolution, as well as those of the other cities, was submitted to the President and the Secretary of State, but was unheeded. 


\section{$\mathrm{XX}$}

\section{DENIS KEARNYISM ONCE MORE-II}

7 HE resolutions of the chambers of commerce of four great cities on the Pacific Coast, which we

1 have noted in the preceding chapter, were received in Japan with great satisfaction and a profound sense of relief. But the joy brought by the pleasant tidings was soon to be dispelled by the anxiety caused by the disquieting news from San Francisco. The Japanese had hoped that such outrages as had been perpetrated in San Francisco during the previous fall would never be repeated. They had cherished the belief that the good sense of the citizens of that city and the efficiency of its police authorities would make such disorderly conduct impossible. But in this they were sorely disappointed. Almost upon the heels of the reassuring declarations made by other cities on the Pacific Coast, a number of Japanese restaurants in San Francisco were once again subjected to violent attacks and intimidation at the hands of hoodlums and laborers.

The fresh outrages were started in the usual manner. One evening in May, 1907, four white men, belonging to labor unions, were taking supper in a Japanese eatinghouse. Presently another party of union men, acting apparently on a preconcerted plan, appeared in front of the restaurant, and, after talking loudly and in vile language at the entrance, ordered the four men, who were eating supper, to come out. Two of the men did go out, 
and as soon as they reached the sidewalk they were assaulted, knocked down, and beaten. The object of the attacking party was, evidently, to punish their fellows for patronizing a Japanese restaurant, but the uproar soon attracted a crowd, made up mostly of hoodlums and roughs. Instantly the mob spirit was let loose, and the crowd, not satisfied with the punishment of the customers, proceeded to wreck the restaurant. By the time the destruction of the windows and furniture and dishes was completed, the passions of the rioters had been spurred to such a pitch that they forthwith started to destroy a Japanese bath-house opposite the restaurant on the other side of the street. Several calls for the police had been sounded, but no officer appeared in the scene of violence. For several consecutive nights after this incident, laborers and hoodlums visited various Japanese restaurants, breathing threats and often resorting to violence.

To be sure, these occurrences were deplorable enough, but it was unfortunate that they should have been brought by the Japanese ambassador to the notice of the President or the Secretary of State. It ought to have been remembered that at the time San Francisco, whose energies had been overtaxed in the struggle to rise from the ruins spread by the earthquake and conflagration, was also hampered by the street-car strike, which occasioned much disorder throughout the city. Hoodlum sympathizers with the striking carmen stoned cars, assaulted peaceable citizens, and even insulted women, among whom was the wife of the Chief Justice of the Supreme Court. The throwing of stones and bricks, and the exploding of dynamite and infernal machines were almost the order of the day. The apostles 
of Japanese exclusion did not, of course, scruple to take advantage of this general reign of lawlessness, and employed all the means at their command to aggravate the outrages perpetrated by the hoodlums against the Japanese. That such a dismal state of affairs should be permitted to prevail certainly did not reflect favorably upon the efficiency and integrity of the municipal government of San Francisco, and yet one could be lenient towards it if one remembered the terrific calamity that had overtaken the city. Apparently the Japanese ambassador of that time did not feel obliged to view the situation so sympathetically, and saw it fit to call the President's attention, in a friendly, informal way, to the abuses to which the Japanese in San Francisco had been subjected. Mr. Roosevelt received the ambassador's reminder with what courtesy the conventional etiquette of diplomacy might require, but in the bottom of his heart he no doubt felt somewhat annoyed to see such petty incidents thrust into delicate diplomacy. The President, moreover, probably regarded it as an affront to the national pride of his country that an ambassador from a foreign nation should remind him so frequently of the disorders prevailing in a section of his country. At any rate it was a regrettable move that was taken by Ambassador Aoki, and it was small wonder that about that time the President's displeasure with the Japanese ambassador began to be rumored abroad.

More diplomatic was the move taken by the leading chambers of commerce in Japan. Brief messages cabled to the Japanese press with regard to the renewed attack of laborers upon Japanese business establishments in San Francisco created intense anxiety, as the extent of damage suffered and the nature of outrages could not 
be ascertained at the time. The Japanese chambers of commerce discerned, in the frequent occurrence of antiJapanese demonstrations in California, a grave danger to the traditional friendship which had bound together America and Japan for half a century, and felt constrained to do something to alleviate the situation. At the same time they were anxious that the matter would not be turned into diplomatic channels, as such a course would only result in aggravating the situation by putting both the Tolkio and the Washington government in an embarrassing position. Consequently they decided to appeal to their sister organizations in America in the name of commerce and trade. The result was the joint note of the five most influential chambers of commerce in Japan addressed to the leading chambers of commerce in America, requesting the latter to exercise their wholesome influence for the betterment of conditions in San Francisco.

The action of the Japanese chambers of commerce was no doubt suggested by the previous resolution of the chambers of commerce on the Pacific Coast, which we have already noted. The Japanese appeal was, on the whole, well received on this side of the water. The Chamber of Commerce of Seattle responded to it with a most cordial letter, a passage from which is here reproduced:

"In the future, as in the past, Seattle will always be found standing for justice and fair play for the Japanese, as well as for all other nationalities within her borders. For more than ten years Seattle has been the American home port of the Nippon Yusen Kaisha, the great Japanese steamship company. This company has been a pioneer in opening up a profitable and friendly trade 
between the two countries. Commerce in our day is the most powerful and persuasive ambassador of peace and good-will among nations. It brings the people of the world closer together, removes prejudices and promotes national friendships. Not the least important mission of chambers of commerce-the spokesmen, so to speak, of the commerce of their respective countries-is to coöperate with one another in smoothing away and compromising the differences that inevitably arise from time to time between the peoples of different countries, as between communities in the same country. In this spirit, and with this end in view, the Seattle Chamber of Commerce extends to the chambers of commerce of the cities of Tokio, Osaka, Kyoto, Yokohama and Kobe its most friendly consideration, and trusts that the good relations which have existed so long between our cities, as between our countries, and with such manifest advantage to both, may continue unbroken into the far future."

A most auspicious sequel to this exchange of views between Japanese and American chambers of commerce was the mutual visits of the leading financiers and business men of each country to the other, to which reference will be made in the proper place. That the exchange of cordialities between the commercial organizations of the two countries materially contributed to the brightening of Japanese-American relations in general cannot be doubted, even if it may not have produced any direct effect upon the Japanese situation in San Francisco.

Meanwhile, the American government proceeded to take measures for the exclusion of Japanese laborers, whether skilled or unskilled. By this time it became evident that Mr. Roosevelt's attitude towards the Japanese question had changed perceptibly. When he penned that 
memorable message of December, 1906, wherein he extolled the Japanese in a manner which almost embarrassed them, he had, I am inclined to believe, no idea of indorsing the programme of the Japanese and Korean Exclusion League. Indeed he was so enthusiastic in praising the Japanese that he recommended that Congress provide for their naturalization. Did he now regret that he had ever made so strong a case for the Mikado's subjects? At any rate, he accepted, willingly or unwillingly, the main contention of the Exclusion League after he conferred with the California delegates headed by the now disgraced Mayor Schmitz. Mr. Roosevelt immediately took steps towards the fulfillment of the promise he had given the delegates, and entered into negotiation with the Japanese government, which showed a willingness to adjust the matter along the line marked out by the President. And yet the exclusionists did not stop their agitation; so far from it, they caused a group of politicians to introduce in the California legislature several bills directed against the Japanese residents in that state. Fortunately the enactment of such discriminative laws was prevented by the vigorous protest from Mr. Roosevelt. In March, I907, he telegraphed to Governor Gillette, of California, a message, contending that the action of the state legislature was most unfortunate in the effect upon his efforts to secure the exclusion of Japanese laborers by friendly agreement. Then followed a number of letters from him, resulting in the withdrawal of the anti-Japanese bills.

Up to that time, the activities of the Japanese and Korean Exclusion League were confined to California. The state of Washington was friendlily disposed towards the Japanese immigrants who had been arriving there in considerable numbers. As for Oregon, she had no 
reason for taking any interest in the propaganda, for her Japanese population was a negligible quantity. So the agitators of California determined to arouse an antiJapanese prejudice among the people of other Pacific Coast states. The Exclusion League set up branches in Portland and Seattle and called mass-meetings of laborers to demonstrate against the Japanese. Not only this, but the league stretched its hands into British Columbia, and tried to invest the organization with an international nature. This latter move was extremely opportune, as Japanese laborers in Hawaii, after the doors of continental United States had been closed against them, began to enter British Columbia in numbers larger than ever before. This was arousing apprehension among the working men in the province, and the Exclusion League of California saw in the situation a God-sent opportunity.

At this time the Seattle branch of the league was directed by a picturesque character. A hotel cook by trade, he cherished an ambition out of all proportion to his ability, his training, and his education. Being a working man he aspired to authority in the field of organized labor. If Samuel Gompers and John Mitchell could rise from the rank of laborers to the dizzy heights of fame, why not he? To his chagrin, the established trade unions of Seattle were not anxious to confer upon him a crown of leadership. In the moment of despondency an inspiration rekindled his ambition. He saw that the anti-Japanese campaign in San Francisco lifted O. A. Tveitmoe from obscurity, and made him one of the most talked-about men on the Pacific Coast. If Tveitmoe could do that down in San Francisco, why could he not do the same up in Seattle? So Arthur E. Fowler-for such was the name of this aspiring hotel 
cook-set out to preach the gospel of Japanese exclusion, talking about the "Yellow Peril" and all that. Nobody listened. Perhaps he had better get somebody who could talk louder to help him, so he got into communication with Tveitmoe. The arch-exclusionist of San Francisco fancied he found in Fowler an able lieutenant, and the Seattle branch of the Exclusion League was immediately established.

Fowler's chance had at last arrived. He scented a growing feeling of antipathy towards the Japanese immigrants in Vancouver. To Vancouver he rushed, and there he revealed to his fellow agitators in British Columbia the favorite tactics of the Exclusion League. The result was the disturbance of September 7, 1907. Imagine Fowler's delight. He saw his name printed in all the papers on the Pacific Coast; he surely felt like a man who woke up one fine morning to find himself famous. But alas! his fame was not to last. Only a few days after the Vancouver incident, he appeared in Bellingham, Washington, on the holy mission of exclusion. But even before he opened his crusade there, the police of Bellingham put him under arrest, the judge declared him insane, and committed him to the asylum at Stellacoom. Thus began and ended the career of the secretary of the Japanese and Korean Exclusion League in Seattle. His disappearance from the stage of agitation was mourned by the Seattle Post Intelligencer in these terms eminently fit for the occasion:

"No man of gentle impulses will be inclined to pass harsh judgment upon Arthur E. Fowler, secretary of the Japanese-Korean Exclusion League, who has been adjudged insane by Judge John A. Kellogg, of Bellingham, and committed to the Stellacoom asylum. Fowler's mis- 
sion was not holy. There is no need in this free country for work of the kind prosecuted by this unhappy man and his associates.

"Fowler's fate is supremely pathetic. There may be a warning in it for other men who seek to subvert American principles and blot out all that is good and enduring in the tradition and sentiment of this nation.

"Of such strength is the faith of the average American in his own country and its institutions that he is not afraid to share his fortunes with the friendly stranger, without regard to race, lineage or color; indeed, if he has any fear at all, it is of princely meddlers, fair of skin and smooth of speech, who come hither to talk rather than to toil, rather than of honest plodders who come asking only the privilege of respecting the nation, its laws, customs and institutions, while they dig their living out of the ground."

Fowler's fall and the general unpopularity of the Exclusion League in Seattle, and indeed in Washington, worried Tveitmoe and his associates. They had dreamed of effecting one strong organization that would embrace all Western states and British Columbia, and thus convert the entire Pacific slope from Los Angeles to Vancouver into a solid bulwark to keep the Japanese out. Now their pleasant dream was broken by the rude shock of Fowler's downfall. Yet they were not daunted, and decided to carry war into the camp of the enemy. In accordance with this resolution they held, early in February, 1908, an interstate conference in Seattle, the city which had hissed Fowler off the stage. Again their efforts proved utterly futile. The exclusionists came thither with the avowed object of creating a stronghold of antiexclusion sentiment, but when the campaign was over 
they found they had scored a failure. The Seattle Post Intelligencer awaited the coming of the exclusionist delegates, with its broadside ready to open fire upon them. The day before the arrival of the delegates this paper sounded a warning to what it called "unwelcome guests," saying :

"Delegates who may come to Seattle to attend the meeting of the Japanese-Korean Exclusion League tomorrow will be unwelcome. They are not wanted in this community, and the pity is that the law does not afford a means of keeping them away. . . . When these meddlers meet in the city of Seattle, if they must meet here, it will behoove them to speak and act with caution. In utterance or act, there must be no violence in this community, due to the presence here of foreign agitators who wear the livery of Americanism merely to defile it; else they may find that the real Americans of this city can do a little excluding on their own account, with a primitive rawness that might have the smell of tar and feathers."

It did not take long for the exclusionists to find out that they were utterly out of place in that metropolis of the Pacific Northwest. But that was not the worst they experienced. They quarrelled among themselves upon the question of distribution of offices, and it was in sullen mood and with blighted hopes that the delegates left Seattle.

Meanwhile Japan earnestly set to the task of stopping the emigration of her laborers to the United States, and approached the American government with what she considered to be a workable plan. The plan was accepted by the Washington administration, and thus the two nations found the way to act in unison. It happened just 
at this time that the Atlantic squadron of America left home waters on a cruise around the world. The event occasioned many wild rumors both in America and in Europe. Not a few American newspapers intimated that the cruise was intended to be a demonstration directed at Japan, in order to bring the immigration question into a speedy settlement. The Japanese, like all Orientals, they said, were insincere and evasive, and that nothing could appeal to them more forcibly than display of force. They failed to see that their unwarranted comments were calculated to estrange Japan and America, and to impair the traditional friendship between the two nations, which they themselves certainly desired to maintain. Apparently they could not realize that the Japanese were no less proud and patriotic than the Americans, and that any allusion to the cruise of the Atlantic fleet as the manifestation of the "big stick" policy must rasp the tenderest nerve of the Japanese people. The Japanese are, in a sense, a people of strong sentiments and have in many instances shown themselves capable of acting in utter disregard of the idea of gain or loss, when once their pride was deeply affected. Such a nation would be the last to bow to military prowess paraded before its eyes. If Japan and America are to be good friends, as they indeed must, neither should affront the other by the exhibition of force, but each must take the other into confidence and act with sympathy and consideration.

But to come back to the Atlantic squadron. European newspapers, and especially those of Paris, were even more sensational in reporting the departure of the fleet for the Far East. Some of these papers had the audacity to report that the Japanese navy was secretly preparing to challenge the American fleet, coloring the report with 
the invented story of mysterious movements of the Mikado's men-of-war. Worse still, an anonymous writer, presumably a German, circulated a pamphlet in London, describing the "coming conflict" between Japan and America. Obviously there were some agents of mischief at work with the sinister intention to alienate American sympathy from Japan. Shortly afterwards a German novel, elaborating the plot set forth in the pamphlet, was published in Berlin, and its English version appeared in New York. But the Japanese government and people had too much sense and too strong a confidence in the American government to be disturbed by such tricks, and it was but natural that they should have extended to the American battle-ships the most enthusiastic welcome and the most cordial treatment. In view of these circumstances it was regrettable that, almost a year after Japan welcomed the American squadron, Mr. Roosevelt, discussing in the Outlook the question of Japanese immigration, should refer to a powerful navy as a necessary means of enforcing the restriction of immigration. The reference may have implied no reflection upon the integrity of Japan, but it sounded very much like an intimation that the visit of the American battle-ship squadron to Japanese waters was really intended to intimidate the Japanese, and that the Japanese government would not adhere to the exclusion understanding, unless the United States had a navy powerful enough to prevent its violation. Were American newspapers right after all, when they believed that the cruise of the Atlantic fleet was not purely a practice cruise? And were the Japanese after all simpletons to take the call of the American fleet at their ports for a mark of friendship? However, it is not given to humanity never to err, and even $\mathrm{Mr}$. 
Roosevelt cannot be absolutely free from indiscretions. In our admiration of his patriotism, his probity, and his straightforwardness, we can gladly forget small blunders that he may occasionally commit.

The smoldering embers of anti-Japanese agitation in California once again threatened to rekindle a conflagration in January, 1909. The legislature of California had submitted for its consideration several discriminatory bills all directed at the Japanese residents in that state. The first of these bills denied the Japanese the ownership of land; the second provided that no Japanese should be appointed director of any corporation in California; the third conferred upon the municipal governments in that state the option to segregate Japanese from the residential quarters of American citizens. While the term "aliens" instead of "Japanese" was used in these bills, it was all but evident that they aimed at the Japanese. For while European immigrants could be easily naturalized, the Japanese were barred from becoming American citizens. The fourth anti-Japanese bill, like the measure taken by the San Francisco school board three years previously, provided for the segregation of Japanese children in all the schools throughout the state. In this last-named bill the exclusionist legislators meant to hit Japan straight in the face, for here they used the specific term "Japanese" in place of the general term "aliens." Needless to say that these bills were introduced through the influence and agitation of the Exclusion League. When President Roosevelt learned of the introduction of these bills, he lost no time in launching a vigorous protest on the ground that their enactment would be in violation of the rights conferred upon the Japanese by treaty, which was the supreme law of the land. He also 
contended that the bills, if passed, would result only in defeating the main purpose, which was the exclusion of Japanese laborers. Governor Gillette and Speaker Stanton, of the California Assembly, took sides with the President, and exercised their influence to prevent the passage of the bills. Once more the league failed to attain its coveted end. 


\section{XXI}

\section{JAPANESE IMMIGRATION AFTER THE EXCLUSION AGREEMENT}

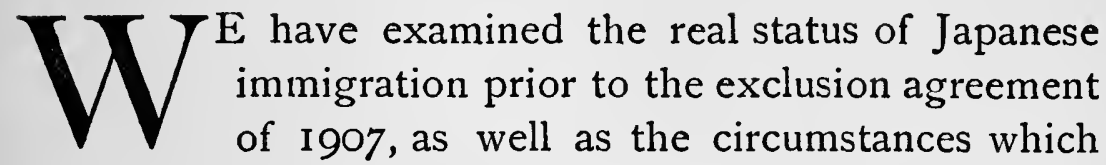
forced that agreement upon the Roosevelt administration. It remains for us to inquire what the exclusion agreement is and what it has actually achieved.

In fulfillment of the promise Mr. Roosevelt made to Mayor Schmitz and the school board of San Francisco early in 1907, the President caused the Congress to incorporate, in the Immigration Act approved on February $25^{\text {th }}$ of that year, the following provision:

"Whenever the President shall be satisfied that passports issued by any foreign government to its citizens to go to any other country than the United States or to any insular possession of the United States or to the Canal Zone are being used for the purpose of enabling the holders to come to the continental territory of the United States to the detriment of labor conditions therein, the President may refuse to permit such citizens of the country issuing such passports to enter the continental territory of the United States from such other country or from such insular possessions or from the Canal Zone."

On the basis of this provision the President, on March I4, 1907, issued a proclamation excluding from continental United States "Japanese or Korean laborers, 
skilled or unskilled, who have received passports to go to Mexico, Canada, or Hawaii, and come therefrom." To put this executive order into operation, the Department of Commerce and Labor, on March 26, 1907, issued a circular which reads as follows :

"Aliens from Japan or Korea are subject to the general immigration laws.

“ Every Japanese or Korean laborer, skilled or unskilled, applying for admission at a seaport or at a land border port of the United States, and having in his possession a passport issued by the government of Japan, entitling him to proceed only to Mexico, Canada, or Hawaii, shall be refused admission.

"If a Japanese or Korean alien applies for admission and presents a passport entitling him to enter the United States, or one which is not limited to Mexico, Canada, or Hawaii, he shall be admitted, if it appears that he does not belong to any of the classes of aliens excluded by the general immigration laws.

"If a Japanese or Korean alien applies for admission and presents a passport limited to Mexico, Canada, or Hawaii, and claims that he is not a laborer, either skilled or unskilled, reasonable proof of this claim shall be required in order to permit him to enter the United States.

"If a Japanese or Korean skilled or unskilled laborer is found in the continental territory of the United States without having been duly admitted upon inspection, the procedure employed under the general immigration laws for the arrest and hearing of aliens who have entered the United States surreptitiously shall be observed."

Meanwhile the American government entered into negotiation with the Japanese government with a view to securing its coöperation in the enforcement of the 
immigration regulations. Japan willingly acceded to the American request, and suggested plans for the control of immigrants. Thus an understanding was reached, contemplating that the Japanese government should issue passports to continental United States only to such of its subjects as were "non-laborers" or were laborers who, in coming to the continent, sought to resume a formerly acquired domicile, to join a parent, wife or children residing there, or to assume active control of an already possessed interest in a farming enterprise in this country; so that the three classes of laborers entitled to receive passports to continental United States have come to be known by the following designations :

I. Former residents.

II. Parents, wives, or children of residents.

III. Settled agriculturists.

The American government, in negotiating the exclusion of Japanese laborers, was chiefly concerned with the conditions on the Pacific Coast, and had little, or no idea of extending to Hawaii the application of the exclusion agreement. But the Japanese government of its own initiative and volition decided to issue passports to Hawaii only to those laborers who were former residents, or parents, wives, or children of residents. This unexpected move on the part of Japan was by no means an agreeable surprise to the sugar interests in Hawaii and their allies on the Pacific Coast. They had urged the exclusion of Japanese laborers from the continental territory with the object of checking the exodus of Japanese laborers from Hawaii, so that the sugar planters might have an abundant supply of cheap labor. They had dreamed that the happy days were coming when the Japanese laborers would be completely at their mercy, accepting what 
wages employers would deign to give. Whether the Japanese government espied their designs or not, it is a fact that its act in restricting the immigration of its subjects to Hawaii proved a great disappointment to the sugar interests of the island.

We have explained the scope and nature of the exclusion understanding, and are in a position to describe its practical working. The regulations concerning the exclusion of Japanese laborers came into effect in March, 1907 ; yet Japanese immigrants for the fiscal year 1907 totalled 30,226 , the figures being the largest in the history of Japanese immigration to America. From this the uninformed may infer that the exclusion regulations failed, in the first year at all events, to attain the end for which they were adopted. The inference is wrong. Although the exclusion regulations were issued in March, 1907, it required a considerable time to complete the preparations necessary for their enforcement and to obtain Japanese coöperation without which they could not accomplish satisfactory results. Consequently the new arrangement did not begin to work smoothly in all its details until July or August of that year. It will, therefore, be seen that Japanese immigration for the fiscal year 1907, extending from July, 1906, to June, 1907, was affected but little by the new system. On the contrary the high state of prosperity, which prevailed in this country during that year, brought an unusually large number of immigrants from Japan, as also from European countries. European immigrants for that year totalled $1,199,566$, breaking all records in the immigration history of America. The same circumstances which swelled the tide of European immigration produced similar effects upon Japanese immigration. 
By the middle of the summer of 1907 , however, the effects of the new system began to be perceptible. Japan, on her part, had been striving to put the official machinery for the control of her emigrants to America in efficient working order. The united efforts of the two governments could not fail to produce a marked effect. Thus in the fiscal year ended June 30, 1908, Japanese immigrants totalled I 5,803 , showing a decrease of 14,423 as compared with the total for the preceding year. This result, remarkable as it was, was not quite up to the expectations of the two governments. By the summer of 1908, however, the official machineries of both Japan and America for the control of immigration had attained a greater degree of efficiency, in consequence of which Japanese immigrants for the year ended June 30, 1909, declined to 3,430 , as against which no less than 7,382 left this country for their home land, resulting in a decrease of 3,952 in the Japanese population in Hawaii and the mainland. Again, in the fiscal year 1910 there were 4,125 immigrants from Japan, whereas 7,379 Japanese returned home, resulting in a decrease of 3,254 in the Japanese population in continental United States and Hawaii. In the following two tables the effects of the exclusion agreement since its inauguration are clearly shown:

\section{Continental United States}

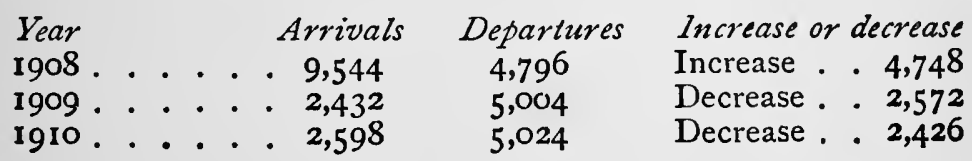

II. HawaII

$\begin{array}{llclr}\text { Year } & & \text { Arrivals } & \text { Departures } & \text { Increase or decrease } \\ \text { 1908... . . . } 8,694 & 4,392 & \text { Increase . . 4,302 } \\ \text { 1909 . . . . . } 1,493 & 2,378 & \text { Decrease. . } 885 \\ \text { 1910. . . . . . } 1,527 & 2,355 & \text { Decrease. . } 828\end{array}$

In examining the above statistics it is important to re- 
member that the majority of the Japanese immigrants were " non-laborers." Indeed, it often is a strain to the susceptibility of Japan to see such of her nationals as high officials, noted scholars or influential financiers treated as immigrants, once they seek admission to this country. It makes not a jot of difference whether they come to buy a million dollars' worth of railway material, or they are en route to Washington or London to assume their duties at the Japanese Legation, or they are sent by the government to carry out some scientific investigation. All the same, they are immigrants, and are reported accordingly by the immigration officials. What an anomaly! Yet the Japanese is willing enough to tolerate the absurdity, if America deems it essential to the maintenance of peace between the two countries to bestow even upon Japanese of high social and official standing the unceremonious appellation of "immigrant." Perhaps, too, it is a bit of American humor or American hospitality to treat all foreign guests, irrespective of rank and title, without superfluous formalities. Let us, then, make ourselves at home here in this land of liberty, however brusque the immigration officials may be.

But I must come back to statistics. I have stated that the majority of the so-called Japanese immigrants are non-laborers who do not come within the scope of the immigration agreement. To verify this statement I present the following table, showing the classification of Japanese immigrants to continental United States into laborers and non-laborers :

$\begin{array}{cccc}\text { Year } & \text { Total immigrants } & \text { Laborers } & \text { Non-laborers } \\ \text { 1908 } & 8,694 & 4,041 & 5,503 \\ 1909 & 1,493 & 713 & 1,719 \\ 1910 & 1,527 & 705 & 1,893\end{array}$


A cursory examination of this table may create an impression that inasmuch as hundreds of Japanese laborers are yet coming to these shores every year, the government at Tokio cannot be strict in adhering to the spirit of the "gentlemen's agreement." To dissipate such erroneous impressions a more critical analysis of statistics is necessary. Let us take, for convenience's sake, the figures for 19I0. The 2,598 Japanese who entered the mainland in that year are classified as follows:

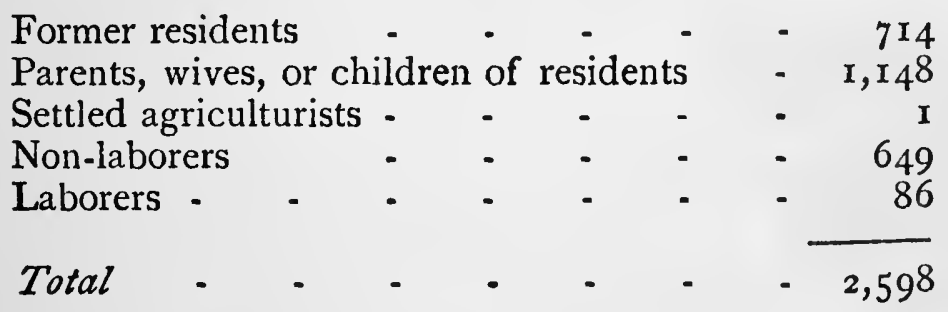

Now "former residents" and " parents, wives, or children of residents" include both laborers and non-laborers, but laborers of these two classes are not, as we have already seen, subject to the exclusion agreement. As the table shows, there were only eighty-four laborers who were neither former residents nor parents, wives or children of residents. Of these eighty-four laborers, fortyseven had proper passports, but the remaining thirty-nine had not proper passports, that is, they had passports to Canada, Mexico, or Hawaii, but not to continental United States. How these thirty-nine laborers with no proper passports were admitted by the immigration authorities is not explained in the report of the Commissioner-General of Immigration. Whatever the reason for their admission, the Japanese government cannot be held responsible for it. As for the forty-seven laborers 
who had passports to continental United States, it is probable that the Japanese government, upon the strength of their statements, regarded them as non-laborers and issued passports accordingly, whereas the immigration authorities of this country, after cross examination, concluded that they were, strictly speaking, not entitled to passports. In handling an enormous number of applications for passports, no government can be absolutely free from errors. It rather bespeaks the effectiveness and sincerity of the efforts of the Japanese government that only so few as forty-seven managed to evade its vigilance and obtain passports without proper qualifications.

We have examined immigration statistics pertaining to continental United States. As for Hawaii, we observe that the number of Japanese laborers coming there was larger than the number of non-laborers, as is shown in the following table:

$\begin{array}{cccc}\text { Year } & \text { Total immigrants } & \text { Laborers } & \text { Non-laborers } \\ 1908 & 8,694 & 5,700 & 2,994 \\ 1909 & 1,493 & 1,213 & 280 \\ 1910 & 1,527 & 1,298 & 235\end{array}$

Further inquiry, however, reveals the fact that almost all the laborers admitted belonged to either one of two classes, i.e., "former residents" and "parents, wives, or children of residents," classes which do not come within the scope of the exclusion agreement. Thus, of I,527 Japanese admitted to Hawaii in 1910, 257 were former residents, I, I66 were parents, wives or children of residents and fifty-eight were non-laborers. Of the remaining forty-six who were all laborers, eleven came without proper passports, while thirty-five, though found not to 
belong to either one of the above-named two classes, had proper passports.

The Japanese government has kept a record of the departure of its subjects for the United States as well as their return home from that country. It is, as the Commissioner-General of Immigration observes, both gratifying and interesting that this record almost agrees with similar records kept by the Immigration Bureau of the United States. The government at Washington, in spite of spasmodic alarms raised by Pacific Coast politicians, is well satisfied with the results accomplished during the past few years, and is fully appreciative of Japan's sincere intention to coöperate with the United States in the matter of immigration. This sense of satisfaction and appreciation is expressed in the Commissioner-General of Immigration's report for the past fiscal year, which contains the following passage:

"The experiment certainly, with the coöperation of the Japanese government, much more completely accomplished the exclusion of Japanese laborers, as defined in the regulations putting the arrangement into effect, than have the Chinese exclusion laws ever operated to prevent the immigration of Chinese laborers, as defined in such laws, and is working at this moment with a greater degree of relative success."

Agitators against Japanese immigration, forced to recognize that the Japanese government is effectively checking the emigration of its subjects to the United States, have invented a new excuse to continue their spurious propaganda. They assert, as does ex-Mayor James D. Phelan, of San Francisco, that " whereas the 'gentlemen's agreement' has apparently kept the Japanese from shipping to American ports, they go to British 
Columbia and Mexico in large numbers and immediately come over the borders to the fat lands and the attractive climate so agreeable to them on the Pacific Coast of the United States." The contention is flimsy, but it shall receive a few words of criticism, lest the public may be misguided. The opponents of Japanese immigration who advance such views ignore the fact that the present understanding between Japan and the United States was inaugurated for the very purpose of stopping the entry of Japanese laborers from Canada and Mexico, as well as Hawaii. They also ignore that the Japanese government is striving to check the emigration of its subjects not only to the United States proper but to the territories contiguous to this country. As a matter of fact, the new arrangement is accomplishing such satisfactory results that the immigration officers in charge of the Mexican and Canadian borders have nothing to complain about the Japanese. On the contrary, their statements bear testimony to the effectiveness of the existing system. As an instance, let me cite the following passage from the latest report of the immigration inspector at El Paso, who deals with the immigration of Japanese by way of the Mexican border:

"The small proportion to which this character of immigration has declined will be readily marked, as the total for the year reached only fifty-six cases, thirty-six of whom were admitted, two debarred, and eighteen were departmental warrant cases. With the lapse of additional time the effectiveness attending the regulation of Japanese immigration by agreement between the two countries interested becomes more forcibly demonstrated. Japanese applicants for admission at Mexican border ports are confined almost wholly to transits, bona fide 
residents of Mexico, or domiciled residents of the United States returning, and the few surreptitious entries represent merely the straggling rear guard of the Japanese immigrants who entered Mexico in such large numbers three or four years ago. The easy effectiveness with which the Japanese coolie-labor problem has been met throws into still sharper contrast the cumbersome, ineffective Chinese-exclusion law with which our officers are daily struggling in an effort to secure a satisfactory enforcement."

The new American-Japanese treaty, which went into effect in July last, contains no reference to the exclusion of Japanese laborers. In the old treaty we find the following article:

"It is, however, understood that this and the succeeding article do not in any way affect the laws, ordinances and regulations with regard to trade, the immigration of laborers, police and public security which are in force or may hereafter be enacted in either of the two countries."

In the new treaty there is no similar article. This fact seems to have created on the Pacific Coast the apprehension that the government at Washington, yielding to Japanese demand, means ultimately to remove the ban placed upon Japanese immigration. Such an apprehension is not warranted. So long as the existing agreement with regard to the exclusion of Japanese laborers cannot be abrogated by the mutual consent of the two governments concerned, the Japanese government will never deviate from the spirit of that agreement, but will exercise all its influence in checking the emigration of its subjects of the laboring class to the United States. Immigration clause or no immigration clause, this policy of Japan will not undergo an iota of alteration under the 
new treaty. Why, then, was Japan anxious to have that clause removed from the new treaty? Simply because the maintenance of such a clause would leave upon Japan the stigma of inferiority. No provision similar to the one cited above is found in any of the treaties which the United States has concluded with those foreign nations whose standing is on a par with that of herself. When the expired American-Japanese treaty was concluded in I 894 Japan was not yet in a position to enter into the comity of nations on a footing of equality, and in consequence she was obliged to acquiesce in the insertion of an immigration clause in that instrument. Since that time, however, the Mikado's Empire has proved its ability to take its position as one of the great powers of the world. And as the Japanese advanced in the path of reform and progress they not unnaturally felt galled by the presence of the immigration clause in the treaty with the United States. The elimination of that clause from the new treaty will confer upon Japan no material benefit, but she will at least have the satisfaction of seeing an obnoxious tarnish removed from her national escutcheon. Meanwhile, the Pacific Coast may rest assured that the new treaty will entail no situation that will impair its welfare and interests. 


\section{XXII}

\section{THE JAPANESE IN CALIFORNIA}

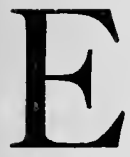

ARLY last year Mr. Mackenzie, Labor Commissioner of California, submitted to Governor Gillette a voluminous report on the Japanese in that state. The report was a shock to the exclusionists. The anti-Japanese agitation had succeeded in forcing the Federal government to erect a barrier against Japanese immigration. The Mikado's government, realizing the embarrassing situation in which the Washington administration had been placed, had willingly agreed to stop the emigration of its subjects to the United States. The Japanese population in California had already begun to decline perceptibly. Everything had seemed to go splendidly with the exclusionists.

Now comes Mr. Mackenzie with the strange recommendation that the Japanese should be admitted to California. Worse still, he contends that the little brown laborer is in some respects even more desirable than the white working man. What an outrage! How could he dare fly in the face of the all-powerful trades unions, and thrust before them such a scandalous proposition? The worst of it is that Mackenzie advances this proposition deliberately, advisedly, and logicaliy, propounding it with figures and statistics, and supporting every statement he makes with substantial evidence. And he does this in a report of more than 200,000 words.

Mr. Mackenzie's report has aroused a storm of protest, 
indignation, bewilderment, ridicule and sarcasm on the part of the laboring elements in California, and the politicians and newspapers, representing and echoing the sentiment of the trades unions. It is as if a nest of hornets were stirred, and the labor commissioner has been made the target of the most stinging criticism. Not a few newspapers have accused him of betraying the trust which was placed upon him by the legislature, in order to serve the interest of the owners of large farms. How much or how little truth there is in such accusations I am not able to judge; but if we were to gauge the value of Mr. Mackenzie's report from the methods he followed in obtaining his data, we are forced to bestow upon the document more than a cursory examination. Let us, then, first see what his methods were.

Early in 1909 the legislature of California approved an appropriation of $\$ 10,000$ to be utilized for investigating the conditions of Japanese in that state. The duty of directing the investigation naturally devolved upon the State Commissioner of Labor Statistics, Mr. John D. Mackenzie. The work was begun on April I5, 1909, with the appointment of nine special agents, of whom eight were men and one woman-all white and Americans. There were no Japanese or other aliens employed in any capacity. To this force of special agents were added for the office work two expert statisticians and two stenographers.

In appointing these field and office workers much stress was laid upon their special fitness for the particular branch of the work to which each was assigned. At the same time it was made plain to them that in view of the small appropriation the investigation could not be properly undertaken and successfully completed without 
the practice of rigid economy, sacrifice of personal comfort, and disregard of the number of hours that constitute a day's work. Preparatory to the undertaking of the field work a general scheme was formulated, so far as practicable, from information then in hand; the general scope of the inquiry, the various lines of industry, and fields of activity were determined upon, and a plan was drafted that could be economically and expeditiously followed. Positive instructions were issued to all special agents, whenever the element of comparison entered, to have all data recorded on schedules or submitted in special reports, free from bias and without prejudice.

One of the most important phases of the inquiry was in connection with the employment of Japanese in agriculture, horticulture, viticulture, and various other divisions of the products of the soil. For the purpose of facilitating and expediting the field work in the interior of the state, the special agents used the cities and towns as a working basis, and carried forward the inquiry, covering the districts by use of horse and buggy, going into the orchards, berry fields, vineyards, beet fields, seed farms, and, in fact, into all fields of agricultural or horticultural industry where Japanese might be employed, whether as a dominant factor or incidental to the requirements of the harvest. The investigation was made by personal visits into all the basins, valleys and foot-hill regions of the state where the cultivation of the soil required labor that was or might be performed by Japanese. Work in the various fields of agriculture commenced with the harvesting of deciduous fruit crops and grapes throughout the state, and the picking of the berry crops, continuing through the seasons of harvesting the later products of orchard and vineyard, and of 
the sugar beet field and the gathering of citrus fruits in the fall and winter.

In this work upward of 4,000 schedules were obtained, covering thirty-six of the fifty-eight counties in the state and including an aggregate of 697,105 acres of cultivated land. The itinerary extended from counties in the extreme north to the southern boundary line, a distance of about I,000 miles. The schedules were obtained from employers of white people, and of Japanese or other Oriental labor exclusively, as well as from those employing both white people and Orientals.

But the investigation was not confined to the condition of Japanese laborers. Special effort was also made to obtain from all Japanese holding leaseholds, tenures or ownerships in lands, or operating farms, vineyards and orchards under various tenures of interest in crops. Visits were also made to packing, drying and shipping plants and wineries. Nor was the inquiry limited to the field of agricultural industries. More than 2,500 schedules were obtained from Japanese engaged in business activities of various characters in isolated communities, as well as in the larger centres of Japanese population throughout the state. This number represents approximately ninety-eight per cent. of the Japanese business houses and other similar establishments in the state.

The investigation included records of articles of incorporation granted to resident Japanese or to foreign Japanese companies licensed by the state; ownership of lands and terms relating thereto; leases of lands and improvements recorded; the character or class of taxes paid; attendance at public schools; inmates of public institutions; information regarding the fishing industries of the state; and the Alaskan fisheries which employ 
San Francisco as a basis of labor supply. In addition to the schedules or blank forms which the agents were required to fill, census cards were prepared, printed both in English and Japanese, and the work of securing the data was carried on coincident with the various other lines of the investigation.

Without entering into unessential details, these were the methods employed by Mr. Mackenzie. Apparently they were comprehensive and well conceived. Granted that they were faithfully followed, there is little doubt that the investigation was likewise exhaustive and thoroughgoing. It behooves us to see what the inquiry disclosed.

Let us first set forth the conclusions reached as the result of the investigation. In Mr. Mackenzie's own words the conclusions are as follows :

"I. That the relationship existing between the farm labor utilized at the present time in the great industries of the orchard, vineyard and field, and the industries themselves have been developed along lines of an evolutionary character, and which are practically impossible of modification in any material degree.

" 2. That the problem of solving the situation by drawing from the present available white farm supply by any known or suggested methods of modification of the conditions now obtaining in this state will afford no practical or material relief.

" 3. That the creation of the ideal intelligent class of white farm labor to be drawn from all sources within the confines of the United States is practically an impossibility, for the reason that such an effort would entail an entire and radical readjustment of economic conditions and the relationship that now exists between the grower 
and the system of transportation, distribution and marketing.

" 4. That the perpetuity or continued development of these great and highly specialized forms of agricultural activity must largely depend upon a supply of labor coming from without the United States, and of such a nature and character as to conform to the conditions resulting from the application of that labor to the agricultural demands.

" 5. That the transition from the cereal-growing period to the development of specialized agriculture increased the ratio of temporary help required by the farming districts beyond the normal available supply within the state during periods of largely increasing population.

" 6 . The necessity for providing the large number of temporary employees engaged in the harvest with employment during the various periods other than the harvest season is a vital element in the solution of the farm labor problem."

The peculiar condition of agriculture in California requires the kind of labor which is capable of independent subsistence, quick mobilization, submissive of instant dismissal and entailing no responsibility upon the employer for continuous employment. The Japanese met these conditions more satisfactorily than any white laborer.

The introduction of Japanese labor into California followed the enactment of the Chinese exclusion act of I 884. Its first appearance was in the great Vaca Valley fruit district, where during the last ten years it has been dominant. But it was not until I 888 that the injection of this new factor made itself noticeably felt. Then some of the growers began to oppose the coming of Japanese as vigorously as they had urged the exclusion of the 
Chinese. Before long, however, they tacitly admitted that Japanese labor was an indispensable element in the development of the industry with which they were identified. They could not be blind to the fact that the successful establishment of fruit growing industry on a profitable basis depended upon a minimum and prompt labor-labor which is not only available on short notice but can be dismissed the moment when the harvest is finished. What they tacitly admitted ten years ago they have since openly declared.

The most important industries in which Japanese are employed are the cultivation of sugar beets, and the picking of grapes. It is shown in Mr. Mackenzie's report that sixty-six per cent. of the entire working force of the sugar beet industry is Japanese. As the work in this industry has been voluntarily surrendered to the Japanese by the white laborers, it has become a matter of serious import whether the Japanese labor shall be continued, and if not, by what means the necessary labor may be obtained to continue the cultivation of beets. The same holds true as to the grape industry, both in raisin and wine grapes. While the cultivation and pruning of the vines are done mostly by white men, more than eighty per cent. of the labor required in picking the grapes is supplied by Japanese.

The success of the Japanese laborer in the field of his largest employment is largely due to his economical method of independent subsistence, the prevalence of the contract labor and boss system, his perfected scheme of mobilization, his peculiar adaptability to any form of agricultural labor and his willingness to work for short periods. Wherever he may be employed, he has reduced subsistence into a science. Not the cost of food alone enters 
into his scientific solution of the problem, but his entire existence is regulated on a basis of rigid economy, so that he reduces the expenditure for essential subsistence to approximately twenty per cent. of his average wages. He practices economy on the basis of his earning power, and does not permit his expenditure to increase in the same ratio as his earnings may increase. The Japanese, earning from $\$ I .25$ to $\$ 1.50$ a day, will spend from twenty to thirty cents a day for subsistence, while the average maximum cost of subsistence for those earning from $\$ 1.75$ to $\$ 2.50$ is thirty-five cents. Though spending so small a portion of his earnings for subsistence, he is enabled to subsist comfortably by eliminating unnecessary waste.

Not less important than the economical method of living is the operation of the boss system. This includes two classes of operators, the field boss and the contractor. The latter was evolved from the former, a necessary resultant of a condition created by the successful employment of field boss in handling labor on a large scale for short periods. The Japanese boss makes a systematic survey of every important field where Japanese labor might successfully compete with other races and especially in those fields where monopoly and ultimate domination might be hoped for. So thorough is this survey that the contractors, lessees, share-workers and field bosses are fully informed of the acreage, the character of crops and the prospective production in their respective districts. They are also familiar with the personality and sentiments of the farm owners, and are well advised as to the utility or futility of any effect towards controlling the labor supply or the securing of leases. While this system is now firmly established, its maintenance in the future is prob- 
lematical, and this for a twofold reason. First, the enforcement of Japanese exclusion has entailed so marked a shortage of Japanese labor that the bosses are beginning to find it difficult to assemble enough men to meet the demand. In the second place, the boss system, while enabling a laborer to earn more money in a given time for a short period, does not accord him much opportunity to share in the profits of his continued labor. Naturally men, preferring steady employment, do not like to work under this system.

Now we are in a position to inquire into the moral character of the Japanese. The reliability of the Japanese contractor of means and responsibility, says $\mathrm{Mr}$. Mackenzie, is as high as that displayed by white men of like responsibility in similar operations. The element of reliability of the Japanese sub-boss, small contractor or laborer is of no lower type than is observed in the available white man in the same class or character of employment. The comparison of the individual Japanese laborer with the individual white laborer of the typical class, which is now in the field, and from which is recruited all the white help now obtainable, discloses a higher standard on the part of the Japanese.

One of the important factors which make the Japanese preferable to the white man as a farm laborer is his peculiar adaptability. No matter how untractable or undependable he may seem in the absence of competition, he reforms quickly in the face of competition, while the white man remains the same under all circumstances, and will not adapt himself to disagreeable conditions. Of course there have been many complaints heard against Japanese regarding their methods in seeking to increase their wages; yet no one questions the efficiency of the 
Japanese laborer in his special field. It is freely admitted that no other labor is available for the work performed by the Japanese. The complaints of the employers of Japanese labor come from the fact that the Japanese are not free from that common weakness-or may we not as well say virtue? - of aspiring for independence. In their zeal to secure higher wages so that they may save in time enough to become owners of farms, they have sometimes emulated the tactics of the white working men, and have gone on strike at the most critical moments. Says the report:

"Japanese ambition to progress beyond mere servility to the plane of the better class of American working men, to own a home, to operate industries, to be master and not slave, is of the same quality as that of the Italian, the Swiss, the Portuguese, and the Russian with whom he competes, and in line with the ambition of that type of American who will not compete with him. The moment that this ambition is exercised, that moment the Japanese ceases to be an ideal laborer."

The character of Japanese tenants and owners of farms is naturally higher than that of mere farm laborers. The Japanese landowners are steady and industrious, and from their earnings purchase land of low value and poor quality. The care lavished upon this land is something remarkable, and frequently its acreage value has increased several hundred per cent. in a year's time. These men, as a rule, show a courtesy that is inbred, and gladly extend hospitality to American visitors. Most of them indicate an intention to make the section in which they have located a permanent home, adopting American customs and manners. Evidence of the desire of the Japanese, whether independent farmers or laborers, "to learn 
English was found in all the quarters visited by the agents. English dictionaries and books were observed among every man's belongings. The Japanese lessees of farms have often been accused by unsympathetic critics of abusing the soil, trying to get all the good out of the ground at a minimum cost and in the shortest possible time. Once a farm is operated by a Japanese tenant, such critics declare, it is certain to become a waste land, which can no longer be cultivated profitably. Such insinuations certainly are not supported by Mr. Mackenzie's report, which states that farms leased to Japanese are, at the expiration of the lease, always sought by white farmers.

One of the arguments advanced by the exclusionists against the Japanese laborers is that they deprive white men of employment by underselling their labor. Yet the facts gathered by Mr. Mackenzie run directly counter to such arguments. The average wage paid by white farmers to white help is $\$ 1.38$ per day with board, and $\$ 1.80$ without board, while the Japanese is paid $\$ 1.49$ per day with board and $\$ 1.54$ without board. This, however, does not furnish the sound basis of comparison, for 49.2 per cent. of the Japanese farm laborers are working by contract or piece work, under which condition their earnings are much larger than those of the whites. The average wages paid Japanese labor by Japanese farmers were even higher than those paid by white farmers, averaging $\$ 1.75$ per day with board.

The erroneous idea that the Japanese immigrants do not consume American goods, but use articles imported from their native land, is clearly pointed out in the report under review. The Japanese in America invariably substitute American food articles for rice and fish which, while at home, constituted their staple food. While rice 
is still the basis of their food, the records of the dealers show that the demand for this staple by the Japanese has decreased approximately fifty per cent. in the past seven or eight years. The Japanese themselves believe that the adoption of American diet increases their capacity for labor. As for the clothes used by Japanese, it is a matter of common knowledge that they are all of American origin.

That section of the Japanese population in California, which is engaged in mercantile business, and activities other than agriculture, is also considered minutely in the report. The special agents visited 2,548 mercantile establishments operated by Japanese. Of this total I,938 were owned by individuals, 550 by partnerships, and 64 by corporations. The aggregate capital of these establishments is estimated at about $\$ 4,000,000$, and their total annual transactions at $\$ 16$, I I 4,000, of which 36.8 per cent. was with the white people. The total annual rent paid by these Japanese is over $\$ 900,000$. The following seven cities have $6 \mathrm{I} .5$ per cent. of the total number of Japanese establishments :

\section{Cities}

Los Angeles

San Francisco

Oakland

Sacramento

Fresno

San José

Stockton
No. Japanese establishments

$\begin{array}{rr}- & 505 \\ - & 497 \\ - & 178 \\ - & 154 \\ - & 101 \\ - & 79 \\ - & 54\end{array}$

San Francisco does not contain the largest number of establishments, but thirty-four per cent. of the entire 
investment and 40.2 per cent. of the entire business transacted are represented in that city.

Let us conclude the review of this report by presenting a set of statistical tables, showing at a glance the status of the Japanese population in California as it was found on January I, I9IO.

\section{Number of Japanese Population}

Total Japanese in state

Total male Japanese - -

Engaged in argiculture $-\quad-\quad 37,000$

Working forghiture - - - $\quad-\quad 27,800$

Working for whites - - - - $\quad 6,244$

Working for Japanese - - - - - $\quad$ - 6,244

Total school children - - - - $\quad$ - $\quad$ I, 1 I 7

Miscellaneous - - - • - $\quad$ I, 440

Number of farms

Farms Owned by Japanese

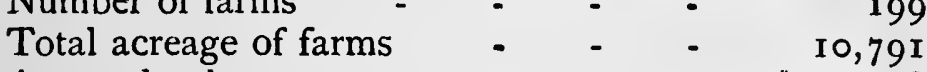

Assessed value - - - - - $\quad \$ 397,298$

Mortgages on farms - - - - $\$$ \$ 74,684

Town Property Ozoned by Japanese

Separate holdings

Assessed value -

Mortgages - - - . - - $\quad \$ 50,359$

Farms Leased by Japanese

Farms operated by crop lessees - . I, I70

Total acreage of same - - • - - 46,480

Farms operated by share lessees - $\quad$ - $\quad 43 \mathrm{I}$

Total acreage of same - $\quad \cdot \quad-\quad 33,028$ 


\section{XXIII}

\section{THE NATURALIZATION OF JAPANESE}

T N December, 1906, President Roosevelt, in his message to Congress, recommended that an act be passed 1 specifically providing for the naturalization of Japanese who come to this country intending to become American citizens. This recommendation aroused at the time but little interest among the Americans: the newspapers and magazines gave it but cursory comment; the Western politicians dismissed it as absurd and impracticable, while their Eastern colleagues seemed unwilling to make it a topic of serious discussion. Perhaps this suggestion of the President's failed to draw the attention it deserved, because it came at a moment when the nation's interest was focussed upon an unfortunate question which had been brought into undeserved prominence-the San Francisco school "incident." It is unfortunate that Mr. Roosevelt himself has since receded from the stand he took when he penned that message. To meet the clamors of the trades unions and agitators of California, he was forced to renounce his former views with regard to the Japanese question. Indeed he has virtually joined the camp of exclusionists, as his recent writings in the Outlook testify.

To the Japanese the question of naturalization is more vital and of greater significance than most other questions that affect them. Indeed it is the sine qua non of the Japanese question of to-day. If this one question shall be solved in a manner satisfactory to them, such 
anti-Japanese bills as have been introduced time and again in the legislature of California will never again be put forward.

I fail to appreciate the justice or wisdom of a law which summarily denies the Japanese the right to become American citizens, irrespective of their individual character, achievements, or social standing. The Japanese in America object to such a law not only because it affects their honor as a race, but because it is prejudicial to their material interests. Many a Japanese has established considerable business in this country; not a few have become prosperous farmers, cultivating large tracts of land. And yet, except in a state or two, no Japanese can lawfully own landed property, because in most states the alien enjoys but limited property rights. Among the Japanese in America, furthermore, are men who, at home, played important parts in the political movement, and who are keenly alive to all vital political issues in this country; among them, such scientists as Dr. Takamine, whose medical discoveries are highly appreciated by all specialists; among them, writers and authors whose names are not only widely known in their native land, but are frequently seen printed in American publications. It is such Japanese as these who are most anxious to see the naturalization law of this country so amended as to qualify them to enjoy the unlimited rights and share the full duties of American citizenship.

Arguments advanced against the naturalization of Japanese are mostly superficial, being founded neither upon the careful study of the naturalization law now in force, nor upon the close investigation into the real status of the Japanese population in America. In the examination of such arguments, we may overlook the 
somewhat sensational utterances of such stark antagonists of the Japanese as Mr. Tveitmoe, president of the Japanese and Korean Exclusion League; what we are concerned with here is the opinion prevailing among those Americans who are able to look at this question more broadly and judiciously.

It is contended that should the United States open to the Japanese the door to citizenship its western coast will be overrun by a horde of ignorant citizens of the laboring class. The absurdity of such apprehension is evident when we consider the safeguard provided in the naturalization law and the satisfactory working of the exclusion agreement. The existing naturalization law is, in my opinion, potent enough to bar out all aliens who are morally or intellectually backward. It reserves to the authorities an ample power of discrimination in naturalizing immigrants. On the other hand, the immigration of Japanese laborers has been so effectively checked that the Pacific Coast need no longer lend ear to the alarmist utterances of professional agitators. Furthermore, Japanese of the laboring class do not, as a rule, care to be naturalized, but they, with few exceptions, return to their native land as soon as they have saved a modest sum of several hundred or a thousand dollars. From whichever side we may view the question, the conclusion seems inevitable that in the event of the right of naturalization being extended to the subjects of Japan, a comparatively small number of Japanese of the best class will avail themselves of the newly granted privilege.

The question, "What class, and how large a portion, of the Japanese in the United States will become American citizens, in case the right of naturalization is extended to them?" is a question which cannot be answered with- 
out venturing upon a statistical study as to the number and occupations of the Japanese in America. Unfortunately, our efforts to reach an accurate conclusion on this point are beset with difficulties, inasmuch as statistical data available for our inquiry are deplorably inadequate.

The annual report of the Commissioner-General of Immigration throws little light upon this question. Perhaps the best available data in this connection are the reports of the Japanese consuls in America for the year 1906. The Foreign Department of Japan divides the United States into four consular districts-(I) the Seattle district, comprising Alaska, Washington, Oregon, Idaho, Wyoming and Montana; (2) the San Francisco district, comprising California, Colorado, New Mexico, Nevada, Arizona and Utah; (3) the Chicago district, comprising Illinois, Indiana, Iowa, Kansas, Wisconsin, Michigan, Nebraska, the Dakotas, Missouri, Arkansas, Texas, Louisiana, Oklahoma, Tennessee, and Ohio; (4) the New York City district, comprising the rest of the United States. Now, at the beginning of 1906, there were I 4, I90 Japanese (I 3,377 males, 81 3 females) in the Seattle district; 31,092 (29,386 males, I,706 females) in the San Francisco district; I,860 (I,755 males, 105 females) in the Chicago district ; and 2,456 (2,358 males, 98 females) in the New York district, aggregating 49,598, of which 2,722 were women.

Since this census was taken five years have elapsed, but as the exclusion agreement was entered into in 1907 , we may presume that the Japanese population has remained almost stationary during the interval of five years. With the consular census of 1906 as the basis of our investigation, we shall proceed to inquire how many 
of this total may be expected to sever allegiance to the Mikado's Empire and swear fidelity to the republic.

In carrying on this inquiry, it behooves us to analyze the Japanese population in the United States by occupation, inasmuch as the question whether or not a Japanese immigrant will stay permanently in this country largely depends upon the nature of vocation he pursues. A railroad laborer or a farm-hand, for instance, almost invariably returns home after several years of toil, but a successful storekeeper or a prosperous farmer would rather stay in this country and be naturalized. The consular census above mentioned gives some information as to the kinds of occupations in which the Japanese in this country are engaged; yet it is impossible to draw an accurate conclusion from this information alone, because not only do the four consulates, which prepared the census, follow different systems in the classification of occupations, apparently with no coöperation among them, but the classifications thus made are so crude that they are of little assistance in our inquiry. The writer, however, has long been interested in an investigation along this line, and through his personal observations and investigations during several years of his sojourn on the Pacific Coast and its adjacent states, in the South and Middle West, and in New York and other states on the Atlantic Coast, he is enabled to modify, elaborate and alter the statements in the consular census, and form a rough idea as to the numbers of his compatriots pursuing different occupations in this country.

We have seen that according to the consular census the aggregate number of the Japanese in America is 49,598. We shall classify this population roughly into the following eight groups: (I) students and officials, 
(2) professionals, (3) merchants and their employees, (4) farmers, (5) farm laborers, (6) railroad laborers, (7) domestic laborers, and (8) miscellaneous laborers. Applying this classification to the Japanese population in each consular district, we obtain the figures in the following table:

San Francisco Seattle Chicago New York Total District District District District

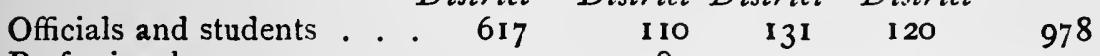

Professionals ....... . I9I $\quad$ I $\quad 84 \quad 35 \quad 100 \quad 410$

Merchants and employees . 1,909

Farmers . . . . . . 1,400 230 60 10 1,700

Farm laborers . . . . 20,000 $1,517 \quad 190 \quad 21,707$

Railroad laborers . . . 2,000 5,029 $442 \quad 7,47$ I

$\begin{array}{lllllll}\text { Domestic laborers } & \text {. . . 3,500 3, 35 I } & \text { I } 24 & 708 & 7,483\end{array}$

$\begin{array}{lllllll}\text { Miscellaneous laborers } & . & 1,475 & 2,665 & 640 & 1,018 & 5,798\end{array}$

Total....... $3 \overline{1,092} \quad \overline{14,190} \quad \overline{1,860} \overline{2,456} \quad \overline{49,598}$

Of these eight classes, students and officials might well be left out of consideration, since they all expect to return to their native country. It is also safe to say that farm, railroad, domestic and miscellaneous laborers will contribute very little, if at all, to the total of American citizens. Unlike many European immigrants, the Japanese immigrant has not burned his bridge behind him, disposing of his all before leaving his native place. On the contrary, he still retains his modest old home, with its few acres of rice-field and its patch of fastidiously cultivated garden; there the spirits of his ancestors still rest in the ancient family sanctuary, and his wife and children are awaiting his return. In his travels in this country, the writer has come in close contact with many laborers of this class, and he feels warranted in stating that they all intend to return home as soon as they have saved a modest sum with which to improve materially their lot in life. 
Now, we must consider the remaining three classes, viz., professionals, merchants and their employees, and independent farmers-classes which are more likely to become naturalized than those already noted. We have seen that there are 4IO professionals, 4,05 I merchants, including employees, and 1,700 farmers. The class of professionals includes scientists, lecturers and instructors connected with American colleges, artists and designers, the staffs of Japanese newspapers published in various parts of this country, and physicians, clergy and teachers working almost exclusively among their fellow countrymen. As to the class of merchants and their employees, it is difficult to know just how many of 4,05 I are merchants; but we are not perhaps straying far from the truth in estimating their number at $\mathrm{I}, 000$, making the remaining 3,05 I represent the total of their employees. This distinction is important, because it is the merchants rather than their employees who are likely to become American citizens. It is, however, among the farmers that we find most of those who are anxious to see the Federal laws so altered as to accord them the full rights of American citizenship.

Thus, excluding all Japanese least likely to be naturalized, we have 3,I IO Japanese (4IO professionals, I,000 merchants, I,700 farmers) who will, when the right of naturalization is extended to them, probably convert themselves into members of the republic. The writer, of course, does not predict that all of these 3, I Io Japanese will renounce allegiance to their fatherland, any more than he claims that there will be no candidate for American citizenship in classes other than those of professionals, merchants and farmers. Presuming, however, that 3,110 out of the aggregate of 49,598 may apply for nat- 
uralization certificates, we reach the conclusion that only six per cent. of the total Japanese population now in this country constitutes a body of possible candidates for American citizenship. What loss will this country suffer in naturalizing such a comparatively small number of industrious, intelligent, even intellectual Japanese? What danger, indeed, will there be in giving them the privilege of voting? Have they not come from a country where a local self-government and a constitutional government have been successfully practiced for a score of years? Does not America allow even Russian peasants to cast the ballot after a few years of residence-peasants who, long oppressed under an absolute government, have no knowledge of the working of a free government until they come to this country?

I have stated that only a small number of Japanese will swear allegiance to the republic; that such Japanese will be recruited from among the best classes of the Mikado's subjects ; that ignorant and undesirable laborers care to remain in this country no longer than is necessary to save a modest sum of money. But, supposing that there are some laborers of the lower class who are desirous of becoming American citizens, is the present naturalization law powerless to discriminate against such applicants? I am inclined to think that the law, if executed strictly, is adequate enough to cope with such a case.

The new naturalization law, which went into effect September, 1907, is doubtless a great improvement upon the old law, its provisions being couched in such elastic terms as would enable the naturalization authorities to prevent the admission into citizenship of those aliens who are morally or intellectually unfit to become members 
of the republic. The law provides that no alien unable to speak English shall be naturalized; that an alien applying for a naturalization certificate must prove that he has resided continuously within the United States for five years at least, and within the state or territory where his certificate is to be obtained one year at least; that he must also make it appear to the satisfaction of the authorities that during his residence in this country he has behaved as a man of good moral character, attached to the principles of the Constitution of the commonwealth, and well disposed to the good order and happiness of the republic, which statement must be verified by the affidavits of at least two creditable witnesses who are American citizens. It will, therefore, be seen that there is much room for the naturalization authorities to employ their own discretion and judgment in their efforts to maintain the moral and intellectual standards of the American nation by preventing the naturalization of undesirable aliens. The educational test, for instance, may be so employed as to bar out almost all Japanese laborers, for it rests entirely with the authorities to decide how well an alien must be able to speak English to be admitted as an American citizen. As a matter of fact, the majority of Japanese laborers do not speak English, while some possess but a smattering knowledge of the language.

Again, the moral test provided in the law is as flexible as the educational test. The court reserves the power to withhold the naturalization certificate until it is convinced that the statement made by the candidate for citizenship as to his moral character is genuine and sincere ; in fine, it entirely depends upon the discretion of the court whether or not an alien can be regarded as 
morally wholesome. In the face of these provisions, the conclusion seems natural that, in the event of the right of naturalization being extended to the Japanese, there will be no danger of the United States becoming infested by the undesirable classes of Japanese immigrants-a conclusion which has also been reached in considering this question from a statistical point of view.

To those Japanese who are desirous of being admitted to American citizenship, the alteration of the unequitable practice of the courts is a matter of urgent concern. Small in number, they are the flower of the Japanese population in America. To enumerate all the representative Japanese in America is alike impracticable and superfluous ; suffice it to say that these are men who are most anxious to see the present naturalization law so changed as to render them justice. Unlike the other classes of Japanese immigrants, most of these Japanesemerchants, farmers and professional men-have brought their wives with them, while some are married to American women. Far from being clannish, the Japanese in America endeavor to adjust themselves to their new environment. In no city have they established their " Chinatown " or their " Ghetto."

It has been asserted that the Mikado's subject is so irrevocably wedded to his native country that he will never become attached to his adopted country. To such a generalization as this, the Japanese in America have but one reply to offer: "Only give us the rights of A merican citizenship, and you will see what sort of citizens we shall make." What more, indeed, can they say, when they have never been given an opportunity to prove their fidelity to the republic? No immigrant, unless he be 
from a degenerate state, enters the threshold of a foreign land without at first cherishing some sense of pride in his own country-without, indeed, the determination that he shall never permit anything to obliterate his love for his fatherland. With all his intense patriotism and his deep love for the Land of the Rising Sun, the Mikado's subject is, after all, not unlike the subject of the Kaiser, who, emigrating to the United States, becomes in a few years an enthusiastic admirer of his new country, ready to defend everything American. It is unfair and unmanly to close to him the door to Americanization, and declare that the son of Nippon is inherently incapable of becoming a faithful member of the republic.

In the disposition of the immigration question, Japan has met every request of the United States with perfect willingness and graciousness. Is it not time that the United States should return Japan's courtesy by admitting Japanese subjects into citizenship? Such a course will certainly prove a potent auxiliary to the traditional friendship between the two nations, without at the same time entailing any undesirable effects upon the welfare and interests of the United States, and especially its Pacific Coast. The Mikado's government will not fail to appreciate it as a vindication of the good-will which this country entertains towards Japan, in spite of the agitations on the Pacific Coast and the spasmodic outbursts of "Hobsonic" jingoism; while those Japanese who will become American citizens will no doubt exercise their influence in furthering friendship between their native and their adopted countries. 


\section{Index}

Allen, Dr. Horace N. :

Adviser to Korea, 163, 165

Assistance to American interests, 242

Minister to Korea, 166

On American enterprise in Korea, 255

On American missionaries in Korea, 280

On Korean characteristics, 153

Pioneer in Korea, 267

America :

American enterprise in Korea, 242-254

American flour in Manchuria, I 33 ; in Korea, 260

American kerosene in Manchuria, 134 ; in Korea, 260

American tobacco in Manchuria, 134 ; in Korea, 262

American cottons in Manchuria, I $35-137$

Exclusion agreement with Japan, $332,338,339$

Exclusion of Japanese immigration to, 331,358

Expedition to Korea, 158, 160

Imperialism of, 62

Japanese consular districts in, 359

Japanese immigration to, 285301

Japanese population in, 359 ; its classification by occupation, 36 I

Korean appeal to, $\mathbf{1} 68$

Korean minister to, 164

Manchurian policy of, $5^{8}$

Naturalization law of, $35^{8}, 364$

Naturalization of Japanese in, 357,362

New treaty with Japan, 34I

Proposed Manchurian railway of, 72,73
Treaty with Korea, 157, 16I, I62, 202

American-British Tobacco Trust, 134,260

Antung-Mukden railway, 45, 46, 90

Bethel, E. T., editor Korea Daily News, 221-223

\section{Californik :}

Anti-Japanese bills in legislature of, 329

Increase of white population in, 291

Investigations concerning Japanese in, 344

Japanese contractors in, $35^{\circ}$

Japanese immigration to, 289, 348

Japanese labor in, 349

Japanese mercantile establishments in, 354

Japanese population in, 355

Labor commissioner's report on Japanese in, 347-355

Moral character of Japanese in, $35^{1}, 35^{2}$

Trades unions in, 313,316

Wages of Japanese in, 353

China:

Characteristic diplomacy of, 79

Her designs upon America, 78, 88

Manchurian policy of, 78-97

Relations with Korea, 147-149, I62, 164

War with Japan, 149

Chinese immigration to America, 291, 300

Chinchou-Aigun' railway question, 72-75, 89

Chientao, Chino-Japanese controversy over, $94-96$ 
Collbran, Henry C. :

His railway enterprise in Korea, 243

His electric trolley and lighting system in Seoul, 244

His water-works in Seoul, 245

$\mathrm{His}$ mining enterprise, 247

Collbran Bostwick Development Co.:

Organization of, 244

Kapsan copper mine of, 247

Litigation with Japanese residency-general, 248

Dealings with Korean emperor, 252

Crane, Charles R., 69

Eastern Chinese Railway:

Coöperation with South Manchuria Railway, 107, 108

Financial difficulties of, $5^{\circ}, 5^{1}$

Railway land of, 52, 53

HARBIN, flour mills in, 36

Russian railway land at, 53

Hawaii, Japanese immigration to, 289, 290, 301, 338

Restriction of Japanese immigration to, 333, 335

Hay, Secretary of State, "opendoor " principle of, 58-60

Hulbert, Homer B. :

On Japanese in Korea, 168, 225, 227

On Korean maladministration, 203

ITo, Prince :

Assassination of, 235, 266

Attitude towards foreign interests in Korea, 249

Attitude towards missionaries in Korea, 272, 273

Control of Japanese in Korea, 217

His letter to American ambassador, 275

Japan, American squadron's visit to, 327

Annexation of Korea by, 237; its effects upon Korea, 238,
239 ; upon foreign interests, 240

Attitude towards missionaries, $27 \mathrm{I}-274$

Control of emigration to America by, $333,335,338,35^{8}$

Commercial success in Manchuria, I 44

Commercial expansion policy of, 122-126

Efforts to maintain Korean independence, 149-153, 173

Enterprises in Korea, 174-185

Manchurian policy of, 113

New treaty with America, 34I

Protectorate over Korea, 152

Reforms in Korea by, 187-201, 204-213

Treaty with Korea, 145

War with China, 149

Japanese and Korean Exclusion League, 307, 312, 322, 326

Japanese immigration to America :

Action of Japanese chamber of commerce on, 319

Agitation against, 306, 329

Beginning of, 285

Causes of exclusion of, 301

Comparison with European immigration, 287, 288, 293, 294. 295,296

Classification by occupation, 292, 336

Decline of, 335

Economic effects upon Pacific Coast of, 297-300, 353, 354

Educational condition of, 296

Extent of, 287, 288

Measures for the exclusion of, $331,33^{2}$

Significance to Pacific Coast of, 289

Wholesome nature of, 294, 295, $35^{\mathrm{I}}$

KNox, Secretary of State, 68, Korea : $69,72,89,106$

Agriculture in, 179, 195

American enterprise in, 242254,255 
American imports to, 260

American trade in, 257, $25^{8}$

American missionaries in, 268

Annexation of, 237

British trade in, 257, 261

Cigarette trade in, 262, 263

Chinese encroachment upon, $145,148,162$

Codification of laws in, 208

Corruption of imperial court of, $187,188,251$

Educational reform in, 200

Exterritoriality in, 202, 240

Fishery in, 180

Foreign journalism in, 221, 222

Insurgency in, 218-220

Japanese appropriation of lands in, 225-227

Japanese courts in, 210-213

Japanese banks in, 177

Japanese expenditure in, 187

Japanese import to, 257, 258

Japanese officials in, 19 I

Japanese railways in, 174, I75

Japanese population in, 182,215 , 216

Japanese postal, telegraph and telephone service in, 176

Japanese protectorate over, 152, 168

Judicial reform in, 202-213

Korean envoy to America, 163

Korean traits, 153

Mining laws in, 249

Native banks in, 194

Official corruption in, 189, 190, 252

Public works in, 192

Recognition of independence of, 145

Russian aggression in, 150

Sanitation in, 198

Treaty with America, 157, 162

Korea Water Works, Limited, 245

Liao-tung Peninsula, leased territory of, 25,26

MANCHURIA :

American trade in, $\mathbf{1 2 7}$

Coal mines in, 27,40
Chinese railways in, 48

German trade in, I3 I

Japanese commercial museums in, 122

Japanese commercial advance in, 67,114

Japanese population in, 39

Japariese railways in, $26,27,32$, $33,44-48,70$

Japanese steamship service to, 124

Lumbering industry in, 28, 42

Open ports of, 29

Products of, I 16, I 17, I 21

Railway guards in, $3^{1}, 55$

Russian railways in, 49,70

Russian trade in, $\mathbf{I}^{2}$

Manchurian bean :

Export to Japan of, 117, 120

Importance of, I 16

Introduction to Europe of, 118

Mackenzie, J. D. :

Labor commissioner of California, 343

Investigations concerning Japanese in California, 344-346

Report on Japanese in California, 347-355

Millard, Thomas F., 38, 172

“OPEN DOOR" in Manchuria, 29, $55,58,64,108$

"Open door" in Korea, 255, 260

Oregon, Japanese in, 299, 300

Increase of white population in, 291

Japanese immigration to, 289

Oriental Consolidated Mining Co., 246

Oriental Development Co., I79, 180, 194

Port Arthur, 56

Preston, W. T. R., on Japanese rule in Korea, 224

Rea, George Bronson, II4-116

Roosevelt, Theodore, 63, 155, 169 , I 70, 308, 309, 319, 321, 328, 329,356

Root, Secretary of State, $68,7 \mathrm{I}$ 
Russia, Korean policy of, 150, I 51 Manchurian railways of, 49,70 Manchurian trade of, $\mathbf{1}^{2}$ Rapprochement with Japan, ror Treaty of peace with Japan, 24

Sammons, Thomas, American Consul-General at Seoul, 264, 276

San Francisco:

Exclusion of Japanese school children in, 307, 308, 309, 31,2 Japan's sympathy with, 314 Lawlessness in, $313,317,318$

Moral integrity of Japanese school children in, 3 IO, 31 I

Seattle, Branch of Exclusion League in, 323

Friendly attitude towards Japan, 315,320

Resolution of Chamber of Commerce of, $3^{15}$

Unpopularity of anti-Japanese agitation in, 324, 325, 326

Schiff, Jacob H., on Russo-Japanese relations, 98

Shinmintung-Fakumen $\mathrm{r}$ a il way question, 80-86, 92

Song-ping-shun, advocacy of Japanese annexation of Korea, 235
Opposition to Korean aristocracy, 231

Rise to power of, 233

Utterances on missionaries, 274

South Manchuria Railway Co., 44, 45,80

Coöperation with Russian railways, 107,108

Railway land of, $5^{2}$

Stevens, D. W., American adviser to Korea, 152, 222

Taft, President W. H., Chinese policy of, 23

Tairen, Japanese metropolis in Manchuria, 39, $5^{6}$

Terauchi, Viscount, Governor-General of Korea, 237

Tveitmoe, O. A., President Japanese Korean Exclusion League, 303

Career of, 304, 305

Anti-Japanese agitation of, 306, 324

WASHINGTON :

Japanese in, 298

Japanese immigration to, 289

Wages of Japanese in, 298

White population in, 29I 





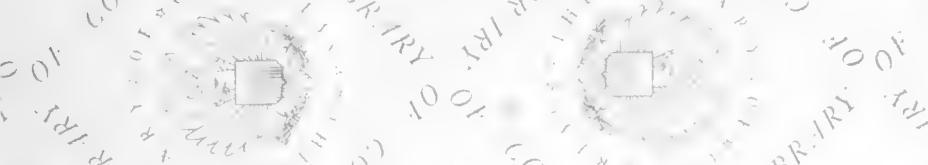

"

$4 \frac{2}{2}$

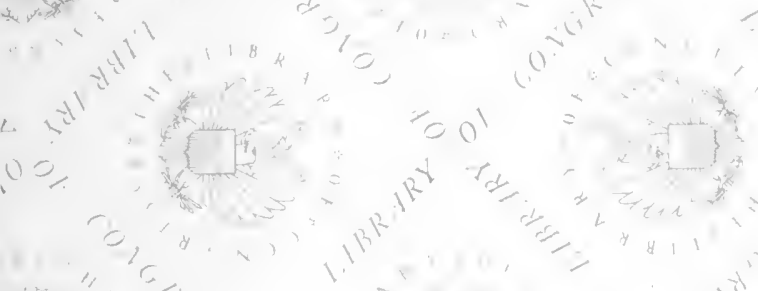

$0^{20}=4$

100

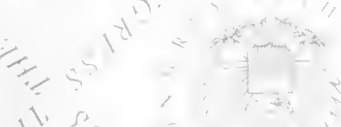

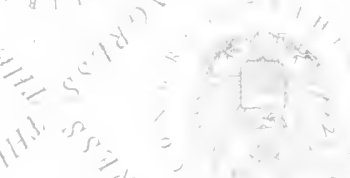

itis

nt.

$\frac{1+3}{2+2}$

ecol

$r^{2}+$

$\left(\frac{1}{3}\right.$

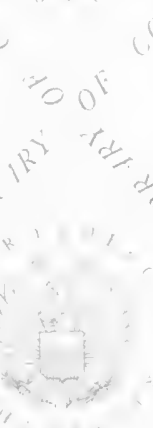

$\therefore-1$

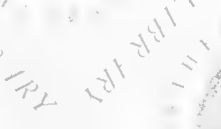

सा

$1,2, x^{+y^{4}}=1$
00

100 ,

col

1

स

$1^{2}$ 
LIBRARY OF CONGRESS

||||||||||||||||||||||||||||||||||||||||||||||||||||||||||||||

00299741588 